\title{
THE FUTURE OF THE PAST TORONTO'S PALIMPSEST
}

\author{
by \\ Ryan Lee \\ B.Arch Sci, Ryerson University 2013 \\ A thesis \\ presented to Ryerson University \\ in partial fulfillment of the \\ requirements for the degree of \\ Master of Architecture \\ in the Program of \\ Architecture
}

Toronto, Ontario, Canada, 2016

(c) Ryan Lee 2016 


\section{AUTHOR'S DECLARATION}

I hereby declare that I am the sole author of this thesis. This is a true copy of the thesis, including any required final revisions, as accepted by my examiners.

I authorize Ryerson University to lend this thesis to other institutions or individuals for the purpose of scholarly research

I further authorize Ryerson University to reproduce this thesis by photocopying or by other means, in total or in part, at the request of other institutions or individuals for the purpose of scholarly research.

I understand that my thesis may be made electronically available to the public. 
The Future of the Past: Toronto's Palimpsest

Ryan Lee

Master of Architecture 2016

Architecture Program, Ryerson University

\section{Abstract}

The architecture of the city is constantly being built and erased and rebuilt again, leaving traces behind. These traces can be read and reused in further designs. However, today new designs disregard these traces of the past, or 'palimpsest.' The preservation and renewal of historic buildings may be seen as presenting an obstacle to the future of the city; however, these buildings hold great meaning for residents. Preservation in architecture often fails to consider the palimpsest that exists within buildings. By finding ways to preserve existing buildings, not as time capsules but as palimpsests, new layers of meaning can be added to architecture.

This thesis will explore palimpsest as an alternative method to preservation and its use in architectural practice. It will present the history and evolution of palimpsest and preservation, and propose a design for Stanley Barracks within the Exhibition Grounds to which palimpsest can bring new depth and meaning. 


\section{Acknowledgements}

Firstly, I would like to express my sincere gratitude to my thesis supervisor, Prof. Kendra Schank-Smith, for her continuous support of my graduate study and thesis research, for her patience, motivation, and immense knowledge. Her guidance helped me through some tough time during my research, writing and design phases for this thesis. I could not have finished without her support and enthusiasm, being a great mentor and teacher.

I would also like to thank the rest of my thesis committee: Prof. June Komisar, Prof. John Cirka and Prof. Ian Macburnie for their insightful comments, critique and encouragement but also for their hard questions which allowed me to challenge my research from various perspectives.

Last but not the least, I would like to thank my family and friends for supporting me throughout the hard times of my graduate studies. They have allowed me to see how we can imagine and create a world that is truly unique. 
To my family \& friends

Thank you all for your support 


\section{Table of Contents}

Author's Declaration

Abstract $v$

Acknowledgements vii

List of Figures xii

List of Appendices xxiv

Introduction 2

\section{Section 1.0 | Palimpsest}

1.1 Introduction 8

1.2 History of Palimpsest 8

$\begin{array}{ll}1.3 \text { Palimpsest as a Metaphor } & 10\end{array}$

1.4 Palimpsest in Archaeology $\quad 12$

1.5 Palimpsest in Urbanism and Landscape $\quad 15$

1.6 Palimpsest in Architecture 17

1.7 Memory in Palimpsest 22

\section{Section 2.0 | Preservation}

2.1 Introduction 30

2.2 The Beginning of Preservation $\quad 31$

2.3 Preservation Terminology 34

2.4 Preservation in the Discourse of Architecture 35

2.5 The Role of Palimpsest in Preservation and Architecture 38

2.5.1 Case Study: National Museum of Roman Art 43

2.5.2 Case Study: Shelter for Roman Archaeology 45

2.5.3 Case Study: Hamar Bispegard Museum 47

2.5.4 Case Study: Neues Museum 49

\section{Section 3.0 | Design Proposal}

3.1 Introduction 56

3.2 The History of Stanley Barracks: Historic Analysis 57

3.3 The Future of Stanley Barracks: Site Analysis 67

3.4 Archaeology Report $\quad 71$

3.5 Design Proposal 73

3.6 The Design 77 


\section{Section 4.0 | Speculation}

4.1 Speculation

\section{Section 5.0 | Appendices}

Appendix A

Appendix $B$

Appendix $C$

Appendix D

Appendix $E$

Appendix $F$

131

Works Cited

133

Works Considered 


\section{List of Figures}

\section{Cover Page}

By author

Introduction

Figure 1: Toronto's Skyline Time Lapse.

By author

\section{Section 1.0 | Palimpsest}

\subsection{Introduction}

Figure 1: Archimedes' Palimpsest showing previous layers of text that remained on the surface that is revealed through modern conservation. Retreived from https://books.google.ca/books?id=_zX80G3QoF4C\&pr intsec $=$ frontcover\&redir_esc $=y \# v=$ onepage $\& q \& f=$ true

\subsection{History of Palimpsest}

Figure 2: The process of making a manuscript palimpsest. Retrieved from http://archimedespalimpsest.org/about/

Figure 3: Archimedes' Palimpsest - before the process of modern conservation.

Photogrpahy by Ann Baldwin Retrieved from http://www. paideiainstitute. org/publications/eidolon

\subsection{Palimpsest as a Metaphor}

Figure 4: Historic map of Rome, 1625, as Freud suggest it to be like a palimpsest.

By Giovanni Maggi retrieved from http://strutturacitta.blogspot.it/2009/05/ cartografia-09.html 


\subsection{Palimpsest as Archaeology}

Figure 5: Architectural objects showing true palimpsest, cumulative palimpsest and spatial palimpsest.

By author

\subsection{Palimpsest in Urbanism and Landscape}

Figure 6: The view of Yonge and Wellington Street showing the city as a palimpsest.

Photograph by author

Figure 7: The view from Wellington Street - North Facade.

Photograph by author

Figure 8: Map of Toronto Fire 1895 and 1904.

By author

\subsection{Palimpsest in Architecture}

Figure 9: A long exposure of the city by Michael Wesley, capturing a place over time examining the city as a palimpsest.

Photography by Michael Wesely retrieved from http://mashable. com/2012/12/14/michael-wesely-moma-photos/\#RRS9taJdhkqP

Figure 10: Plan view of presentation model of University Art Museum of the California State, University at Long Beach, 1986.

Retrieved from Davidson,C., (Ed.)., (2006). Tracing Eisenman. New York, NY: Rizzoli. pg.128. Courtesy Eisenman Architects.

Figure 11: Axonometric of University Art Museum of the California State, University at Long Beach, 1986.

Retrieved from Bedard, J.F., (Ed.)., (1994)., Cities of Artificial Excavation: The work of Peter Eisenman 1978-1989. New York, NY: Rizzoli. pg. 143. Courtesy Eisenman Architects.

Figure 12: Axonometric of Parc de la Villette.

Retrieved from http://images.adsttc.com/media/images/5037/ f5b2/28ba/0d59/9b00/0691/thumb_jpg/stringio.jpg?1414206303

Figure 13: Surface on the landscape.

Photograph by Cyrus Penarroyo retrieved from http://images.adsttc. com/media/images/5037/f594/28ba/0d59/9b00/068e/large_jpg/ stringio.jpg?1414206275

Figure 14: Sketch plan of Parc de la Villette.

Retrieved from http://www.bustler.net/index.php/article/bernard_ tschumi_retrospective_opens_on_april_30_at_centre_pompidou_paris/ Courtesy of Bernard Tschumi, Sketch 1982 Parc de la Villette.

Figure 15: Folly on the landscape. 
Photograph by Cyrus Penarroyo retrieved from http://images.adsttc. com/media/images/5037/f563/28ba/0d59/9b00/0689/large_jpg/ stringio.jpg?1414206284

\subsection{Memory in Palimpsest}

Figure 16:Cascading Gorge, Ithaca New York.

Photograph by Alexy Sergeev retrieved from http://www.asergeev.com/ pictures/archives/2005/468/jpeg/01.jpg

Figure 17: Kolumba Museum in Cologne by Peter Zumthor. By: Carlos Zeballos retrieved from http://architecturalmoleskine.blogspot. ca/2012/04/peter-zumthor-kolumba-museum-cologne.html

Figure 18: New York skyline with 'Towers of Light' fill the sky where the World Trade Centre once stood. The lights traces over the void where the towers once stood, representing the intangible meaning and layers Photograph by Tim Larsen retrieved from http://media.syracuse.com/haveyouheard/photo/2010-09-10-ap-anniversary-lightsjpg-c5a79b7fff6964fe.jpg

\section{Section 2.0 | Preservation}

\subsection{Introduction}

Figure 1: Temple of Vesta also known as Round Temple by the Tiber constantly being adapted, altered and restored several since ancient times. Retrieved from Semes, S.W., (2009)., The Future of the past: A Conservation ethic for architecture, urbanism and historic preservation. New York, NY: W.W. Norton \& Company, Inc. pg. 114.

Figure 2: OMA Venice Biennale 2010 Cronocaos, John Ruskin's attitude towards preservation.

Retrieved from http://www.designboom.com/architecture/rem-koolhaasoma-cronocaos-preservation-tour/ by OMA

Figure 3: OMA Venice Biennale 2010 Cronocaos, Viollet-le-Duc's attitude towards preservation

Retrieved from http://www.designboom.com/architecture/rem-koolhaasoma-cronocaos-preservation-tour/ by OMA

Figure 4: The original wall cleaned, (left) and its pollution on latex (right) at 'The Ethics of Dust, Venice, 2009'

Retrieved from https://placesjournal.org/article/jorge-otero-pailos-andthe-ethics-of-preservation/ by Thyssen-Bornemisza Art Contemporary Foundation T-BA21

Figure 5: Detail of Pollution 'The Ethics of Dust' Retrieved from https://placesjournal.org/article/jorge-otero-pailos-andthe-ethics-of-preservation/ by Museum of the Province of Alto Adige

Figure 6: The original factory wall in the process of being cleaned Retrieved from https://places journal.org/ article 
jorge- otero- pailos-and-the-ethics-of-preservation/ by Museum of the Province of Alto Adige

\subsection{Preservation in the Discourse of Architecture}

Figure 7: Expansion of the scale of preservation over time from Beijing Preservation Study with Harvard, 2003.

Retrieved from http://documents.mx/documents/preservationandthinning-remkoolhaas.html

\subsection{The Role of Palimpsest in Preservation and Architecture}

Figure 8: Bath of Diocletian in Rome, converted by Michelangelo in 1534 from a Roman bath in ruins to Basilica of Santa Maria Angeli.

Retrieved from https://carpelibrum.wordpress.com/

Figure 9: The Great Mosque - Cathedral of Cordoba, converted from a church to a mosque and a cathedral over the centuries.

Photograph by Toni Castillo retrieved from https://s-media-cache-ak0. pinimg.com/736x/41/85/df/4185df1adddba2f12cb901b5f89c082c.jpg

Figure 10: Add-on Approach is where future interventions build upon existing buildings, structures, ruins or traces of remains, where the palimpsest that exist. The following architectural objects shows an exploration of add-on approach.

By author

Figure 11: Wrap Approach seeks to preserve the palimpsest, whether it is found in whole building, ruins artifacts or fragments, by providing a protective layer. The following architectural objects shows an exploration of wrap approach.

By author

Figure 12: Weaving Approach involves weaving the new intervention in and out the existing buildings. The following architectural objects shows an exploration of weaving approach.

By author

Figure 13: Insertion Approach involves new elements being layered onto existing buildings, structures or sites. The following architectural objects shows an exploration of insertion approach.

By author

\subsubsection{Case Study: National Museum of Roman Art}

Figure 14: Section, plans and elevation of the National Museum of Roman Art, in Merida

By Rafael moneo, retrieved from https://s-media-cache-ak0.pinimg. com/736x/87/34/cf/8734cfad5b96c2b9d7bc4b5a54fb5add.jpg

Figure 15: A sculptural fragment of an emperor at the end of the gallery. 
The brick veneer and arched door way recalls the influence of Roman constriction technique.

Photograph by Fabrice Fouillet retrieved from http://www. nytimes. com/2013/04/12/ t-magazine/lost-in-translation.html\#slides how/1 00000003797165/100000003797193

Figure 16: Main gallery of the National Museum of Roman Art Photograph by Fabrice Fouillet retrieved from http://www. nytimes. com/2013/04/12/t-magazine/lost-in-translation.html \#slides how/1 00000003797165/100000003797193

\subsubsection{Case Study: Shelter for Roman Archaeology}

Figure 17: Plan of the Shelter for Roman Archaeology

Edited by Carson Russell retrieved from http://www.arcspace.com/ features/atelier-peter-zumthor/shelters-for-roman-archaeological-site/

Figure 18: Interior view of suspended walkway overlooking the ruins below Photograph by Hazwan Ariff Hakimi retrieved from http://shakespeareintitchfield.weebly.com/shelters-for-roman-archaeological-site--peter-zumthor. html

Figure 19: Interior view of Roman Quarters Photograph by Pol Martin retrieved from http://www.arcspace.com/ features/atelier-peter-zumthor/shelters-for-roman-archaeological-site/

Figure 20: Entrance to the Shelter for Roman Archaeological site Photograph by pol Martin retrieved from http://www.arcspace.com/ features/atelier-peter-zumthor/shelters-for-roman-archaeological-site/

Figure 21: Exterior view of Shelters for Roman Archaeological Site Photograph by Pol Martin retrieved from http://www.arcspace.com/ features/atelier-peter-zumthor/shelters-for-roman-archaeological-site/

Figure 22: Axonometric of Shelters for Roman Archaeological site showing the layers of palimpsest wrapped by the structure.

Edited by Carson Russell retireved from http://www.arcspace.com/ features/atelier-peter-zumthor/shelters-for-roman-archaeological-site/

Figure 23: Section of Shelters for Roman Archaeological Site Edited by Carson Russell retrieved from http://www.arcspace.com/ features/atelier-peter-zumthor/shelters-for-roman-archaeological-site/

\subsubsection{Case Study: Hamar Bispegard Museum}

Figure 24: Axonometric diagram showing the new museum inserted over the ruins of the old fortress and barn

Retrieved from (Brooker. G., and Stone. S., (2004). Rereadings: interior architecture and the design principles of remodelling existing buildings. London, UK: RIBA Enterprises. p. 255) 
Figure 25: Interior view of the concrete ramp through the west wing Photograph by Helene Binet retireved from http://architecturenorway. no/stories/photo-stories/binet-hamar-09/

Figure 26: Plans of the Hamar Bispegard Museum By Sverre Fehn Architects retrieved from http://shakespeareintitchfield. weebly.com/archbishopric-museum-of-hamar--sverre-fehn.html

Figure 27: Exterior view of the detail of the old wall openings with glazing Photograph by Helene Binet retireved from http://architecturenorway. no/stories/photo-stories/binet-hamar-09/

Figure 28: Exterior view from the ramp across the fortress court Photrograhy by Helene Binet retireved from http://architecturenorway. no/stories/photo-stories/binet-hamar-09/

\subsubsection{Case Study: Neues Museum}

Figure 29: Sketch of re-establishment or the tracing of the form and figures

Photograph by David Chipperfield Architects retrieved from http://www. davidchipperfield.co.uk/project/neues_museum

Figure 30: Exterior view of the Neues Museum Photograph by David Chipperfield Architects retrieved from http://www. davidchipperfield.co.uk/project/neues_museum

Figure 31: The process of revealing the layers that remain in the Medieval Room (left) restoration drawing of the Medieval Room floor, (centre) restoration of the room, (right) final interior view Photograph by David Chipperfield Architects retrieved from http://www. davidchipperfield.co.uk/project/neues_museum

Figure 32: The view of the main staircase, (left) 1900 view of the interior, (center) 1945 view of the interior after the bombing of berlin, (right) 2009 reinterpretation of main staircase.

Right photograph by David Chipperfield Architects retrieved from http:// www.davidchipperfield.co.uk/project/neues_museum Center photograph retrieved from http://www.thehistoryblog.com/ archives/3649

Left photograph by David Chipperfield Architects retrieved from http:// www.davidchipperfield.co.uk/project/neues_museum

Figure 33: Neues Museum, 1945, the scars of war can be seen through the decaying state of the museum.

Retrieved from http://www.davidchipperfield.co.uk/project/neues_museum

\section{Section 3.0 | Design Proposal}

\subsection{Introduction}

Figure 1: Aerial view of Downtown Toronto 
Edit by author retrieved from http://blog.waterfrontoronto.ca/nbe/ portal/wt/home/blog-home/posts/john+campbell+speaks+to+the+to ronto+region+board+of+trade+01

Figure 2: View of Stanley Barracks from the lake shore, 1930 Retrieved from Toronto Reference Library: E 1-8k by Margaret Maund Howard 1930

Figure 3: View of Stanley Barracks from the Parade Square looking at the Officers' Barrack.

Retrieved from City of Toronto Archives, Series 327, Subseries 1, File 19

Figure 4: Aerial view of Stanley Barracks with the City of Toronto in the background

Retrieved from City of Toronto Archives, Fonds 1244, Item 326

Figure 5: Troop drill at Stanley Barracks, 1918.

Retrieved from City of Toronto Archives, Fonds 1244, Item 790

Figure 6: View of Stanley Barracks Entrance, 1951

Retrieved from Toronto Reference Library, S 1-1222D by James Victor Salmon

Figure 7: Over the years, the military reserves shrank drastically as the city of Toronto expanded. This diagram shows the Town of York (City of Toronto) in the early 1800's

By author

Figure 8: Diagram showing the Town of York (City of Toronto) expansion in 1866, expanding the town to Bathurst Street

By author

Figure 9: Diagram showing the City of Toronto (formerly the Town of York) in 1878, the construction of the Lunatic asylum on military land, and the new exhibition ground near the New Fort (Stanley Barracks).

By author

Figure 10: Diagram showing the demolition of Stanley Barracks and the expansion of the exhibition grounds

By author

Figure 11: German prisoners of war temporarily housed at Stanley Barracks during WWII.

Retrieved from City of Toronto Archives, Fonds 1244, Item 867.

Figure 12: A bird's eye view of the building at the New Fort including the Officers' quarters 1892

Retrieved from City of Toronto, Staff Report., (2014, March 12). Amendment of Designating By-law and Authority for a Heritage Easement Agreement - 2 Strachan Avenue, City of Toronto.

Figure 13: Aerial photograph Stanley Barracks, 1947 Showing the property 
before the removal of the buildings besides the Officers' Quarters and the replacement of the parade ground with surface parking.

Retrieved from (City of Toronto, Staff Report., (2014, March 12). Amendment of Designating By-law and Authority for a Heritage Easement Agreement - 2 Strachan Avenue, City of Toronto.

Figure 14: A bird's eye view of Stanley Barracks in the context of the Exhibition grounds 1893

Retrieved from (City of Toronto, Staff Report., (2014, March 12). Amendment of Designating By-law and Authority for a Heritage Easement Agreement - 2 Strachan Avenue, City of Toronto.

Figure 15: Aerial photograph Stanley Barracks, 1953 Showing the property after the removal of the buildings besides the Officers' Quarters and the replacement of the parade ground with surface parking. Retrieved from (City of Toronto, Staff Report., (2014, March 12). Amendment of Designating By-law and Authority for a Heritage Easement Agreement - 2 Strachan Avenue, City of Toronto.

Figure 16: Diagram of historical pathway and circulation in 1840 By author

Figure 17: Diagram of historical pathway and circulation in 1880 By author

Figure 18: Diagram of historical pathway and circulation in 1950 By author

Figure 19: Diagram of historical pathway and circulation of the present By author

\subsection{The Future of Stanley Barrack: Site Analysis}

Figure 20: List of designated buildings at the Exhibition Grounds By author

Figure 21: Diagram of Toronto shoreline from 1700 to the present By author

Figure 22: Diagram of surrounding neighbourhoods around Stanley Barracks

By author

Figure 23: Diagram of circulation around Stanley Barracks By author

Figure 24: Diagram of pedestrian circulation around Stanley Barracks By author 3.4 Archaeology Report

Figure 25: ASI archaeological investigation of Stanley Barrack looking 
South

Photograph by Michelle Siu retrieved from http://www.theglobe - andmail. $\mathrm{com} /$ report-on-business/industry-news/property-report/ in-pictureshotel-project-to-honour-torontos-stanley-barracks/ article5663996/

Figure 26: ASI archaeological investigation of Stanley Barracks looking North

Photograph by Michelle Siu retrieved from http://www.theglobe - andmail. $\mathrm{com} /$ report-on-business/industry-news/property-report/in-pictures-hotelproject-to-honour-torontos-stanley-barracks/ article5663996/

Figure 27: ASI archaeological investigation of Stanley Barracks looking East

Photograph by Michelle Siu retrieved from http:// www.theglobe andmail.com/report-on-business/industry-news/property-report/inpictures-hotel-project-to-honour-torontos-stanley-barracks article5663996/

Figure 28: Archaeological artefacts uncovered during archaeological investigation

Retrieved from http://www.asiheritage.ca/portfolio-items-new- fort-site -east-enlisted-mens-barracks/

Figure 29: Stone well uncovered during archaeological investigation Retrieved from http://www. asiheritage.ca/portfolio-items-new -fort-site -east-enlisted-mens-barracks/

Figure 30: Plan of archaeological investigation trenches at Stanley Barrack By author

\subsection{Design Proposal}

Figure 31: Officers' Quarters, 1950's standing surrounding by a sea of parked cars.

Retrieved from City of Toronto Archives, Fonds 1257, Series 1057, Item 744.

Figure 32: 3 Strategies to help reveal the palimpsest in architecture, identify the value, connect the narrative, craft detail and materiality By author

Figure 33: The Royal Canadian Dragoons leaving Stanley Barracks though the main eastern gate, 1925

Retrieved from City of Toronto Archives, Fonds 1266, Item 4985

Figure 34: View of part of Stanley Barracks from top of switch-back looking onto the city

Retrieved from City of Toronto Archives, call number 995-1-10-41b

Figure 35: View of Fort York, water colour, 1813

Retrieved from Toronto Reference Library, JRR678 by Owen Staples 


\subsection{The Design}

Figure 36: View of Stanley Barrack Museum from the northwest corner of the Enercare Centre

By author

Figure 37: Site Plan of proposed Stanley Barrack Museum

By author

Figure 38: Ground Floor Plan

By author

Figure 39: Lower Level Plan

By author

Figure 40: Interior view of ground floor main seating space and the second floor concrete volume over the ruins of Privates' Barrack No. 2 By author

Figure 41: Interior view of the lower level looking into the ruins and stairs leading to second floor

By author

Figure 42: Interior view of the second floor exhibition and flex space

By author

Figure 43: Interior view of the third floor interpretive space

By author

Figure 44: Second Floor Plan

By author

Figure 45: Third Floor Plan

By author

Figure 46: Diagram of building section in three temporal layers, contemporary, historical and interpretive layers

By author

Figure 47: Exploded axonometric of wall section, detailing the facade construction and the three temporal layers, contemporary, historical and interpretive layers

By author

Figure 48: Detail section model detailing the construction of the facade construction

By author

Figure 49: Detail section model detailing the exterior construction and pattern of the facade

By author 
Figure 50: Diagram of plan and section of Stanley Barracks Museum divided into four different sections

By author

Figure 51: Diagram of material selected to be used that draws reference to the historical material used at Stanley Barracks

By author

Figure 52: East elevation of Stanley Barrack Museum

By author

Figure 53: North elevation of Stanley Barrack Museum and the Officers' Quarter

By author

Figure 54: Axonometric of wall section

By author

Figure 55: Exterior view of Stanley Barrack Museum from the northeast corner, across from the Enercare Centre

By author

\section{Section 4.0 | Speculation}

Figure 1: Netropolis Shanghai 2003-2006 By Micael Naijar is part of an exploration of the cities will develop in the future.

Photography by Michael Najjar retrieved from https://anti-utopias.com/ admin/wp-content/uploads/2012/04/netropolis-I-shanghai_72dpi.jpg

\section{Section 5.0 | Appendix}

Appendix C | Design Development

Figure 1: Sketch of master plan for Stanley Barrack Museum By author

Figure 2: Sketch elevation for Stanley Barrack Museum By author

Figure 3: Sketch of interior perspective of ruins By author

Figure 4: Sketch section through the ruins By author

Figure 5: Detail sketch of museum form and facade 1 By author

Figure 6: Detail sketch of museum form and facade 2 By author

Figure 7: Detail preliminary site plan for Stanley Barrack Museum By author 


\section{Appendix D | Design process Circulation Model}

Figure 1: Exploration model of interior circulation and volume that traces the ruins below

By author

Figure 2: Exploration model of interior circulation of the main stairs and seating area

By author

Figure 3: Exploration model of overall view

By author

Figure 4: Exploration model of interior circulation of how visitors can travel to the third floor

By author

Figure 5:Exploration model of interior circulation, alternative circulation of third floor 1

By author

Figure 6: Exploration model of interior circulation, alternative circulation of third floor 2

By author

\section{Appendix E | Design Process of Envelope System}

Figure 1: Detail section of the facade and its relationship to the volume By author

Figure 2a: Detail section of the approach to the ruins and transition to the lower level

By author

Figure 2b: Detail section of the transition to the lower level with seating By author

Figure 3: Detailed section of building facade with a window By author

Figure 4: Detailed section of building facade with varying density of vertical fins

By author

Figure 5: Detailed section of building facade looking at different methods of creating vertical shutters and fins

By author

Figure 6: Detailed section of building facade looking at how to bend and twist vertical fins to create a dynamic facade

By author 


\section{List of Appendices}

Appendix A

Final Drawings

Appendix B

Final Renders

Appendix C

Design Development

Appendix D

Design Process Circulation model

Appendix E

Design Process of Envelope System

\section{Appendix $\mathbf{F}$}

Final Physical Model 


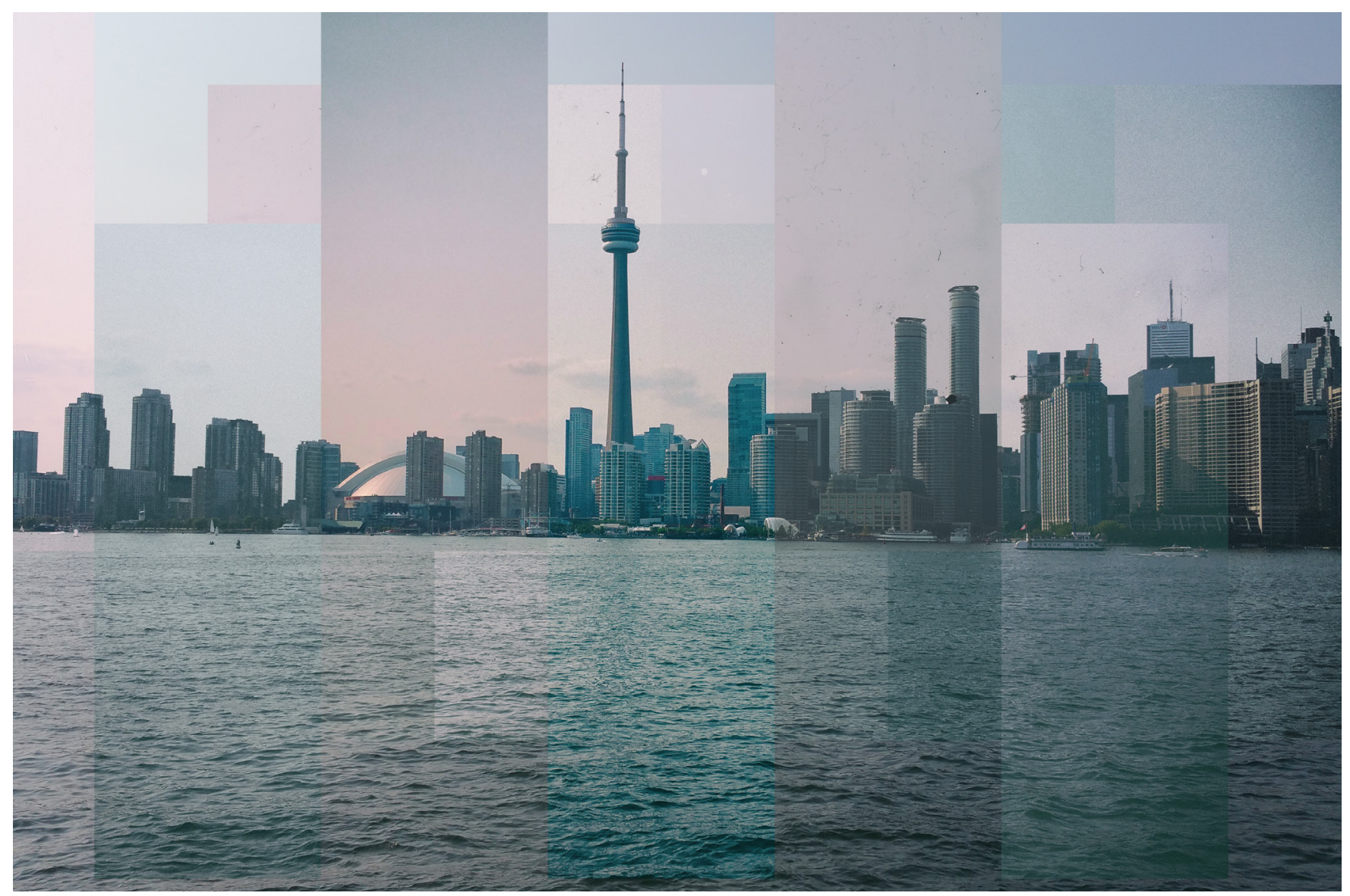

Fig. 1: Toronto's Skyline Time Lapse 


\section{Introduction}

This thesis begins with my interest in how we relate to existing buildings, old or historic, within our built environment. I am also interested in the relationships buildings have with time and history. Looking at the city that we live in today can provides us with evidence of our past through traces that remains.

Like cities, landscapes can provide us with evidence of traces that remain. The continuous process of accumulation and stratification of layers in landscapes can be more easily read and interpreted when this layering is considered as a palimpsest. Cities are similarly constructed in layers. We constantly build and erase buildings, and build again, leaving layers of traces that we can read or interoperate. Whether tangible or intangible, these traces allow us to investigate the complex relationships that existing between the past, present and future.

Cities are constructed through the superimposition of successive layers, building on traces that connect us to the past. Buildings, landscape and 'places' conjure up nostalgic feelings that connect us to our history. They contain memories and experiences that are passed on though traditions, celebrations and rituals that accumulate over time; all these contribute to a city's sense of place and identity.

Every building will one day become old and outdated; some will be preserved, while the majority of them will be demolished and replaced. New designs tend to disregard the values of existing buildings, although there are sometimes preservation efforts to save these buildings. Preservation traditionally demands that we ignores the multiple layers that exist and 
preserving a building to particular time that ignore the palimpsest. Preservation has become an act that strips away time and becomes a by-product of tourism and mass consumer consumption. Adaptive reuse does no better. Government policies and economic demands lead to the consideration of preservation as an afterthought and something that takes away from the value of the existing building.

I believe that our lives and experiences do not consist of a single moment alone, but rather are layered as a natural palimpsest. Our lives are connected to the past; therefore we should use our history, not necessarily in a nostalgic way, but as an inspiration to help us design architecture in a meaningful way. The practice of preservation also fails to take the palimpsest into consideration so that buildings are often left empty and generic. Preservation, conservation and adaptive reuse are strategies that may not consider the past adequately. Therefore, according to Nathaniel Popkin, "by finding way to preserve these kinds of buildings not as museum pieces but as palimpsest itself, will add new layer of meaning [to the buildings experience]" (2012).

This thesis will explore palimpsest as an alternative method to preservation and present its usefulness in the practice of architecture. I will explore the history and evolution of palimpsest and preservation, and propose a design that can use palimpsest as a means of bringing depth and meaning to architecture. 
Lee | 2016 


\section{Section 1.0 Palimpsest}




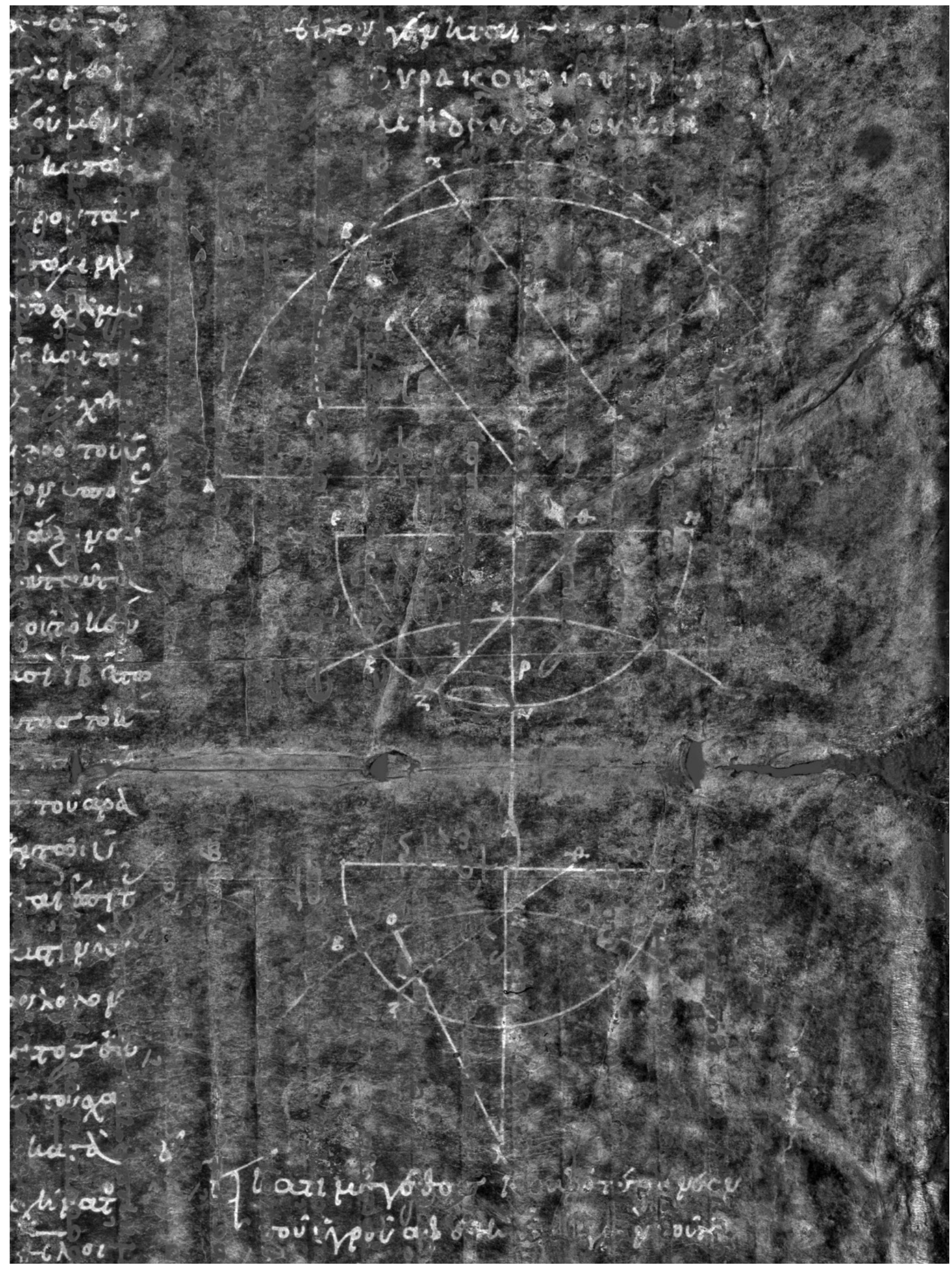




\subsection{Introduction}

The concept of palimpsest is not a new idea within the architectural discourse. The word 'palimpsest' comes from the Latin word 'palimpsestus', which is derived from the Greek word 'palimpsestos' that means 'scraped again' (Oxford English Dictionary, 2015). Architects such as Peter Eisenman, Bernard Tschumi and Rem Koolhaas use 'palimpsest' as a metaphor to describe a building that is written over, partially erased, then written over again, each rewriting leaving traces behind. This suggests that buildings feature multiple layers that preserve parts of its history. It is through interpretation and understanding of these traces that depth and meaning in architecture prevails.

'Palimpsest' suggests a process of transformation through time: this phenomenon that is constantly occurring around us at times leaves traces of material behind. It is a process that occurs over a long period of time: the more layers and objects, artifacts, buildings or landscapes accumulate, the more layers we as designer can work with. This section will explore palimpsest and its evolution, how palimpsest is used in various disciples, and finally to how it can be used as a method in design.

\subsection{History of Palimpsest}

The word 'palimpsest' has a long history dating back to the ancient Greeks. In the Oxford English Dictionary, it describes palimpsest as a noun: 


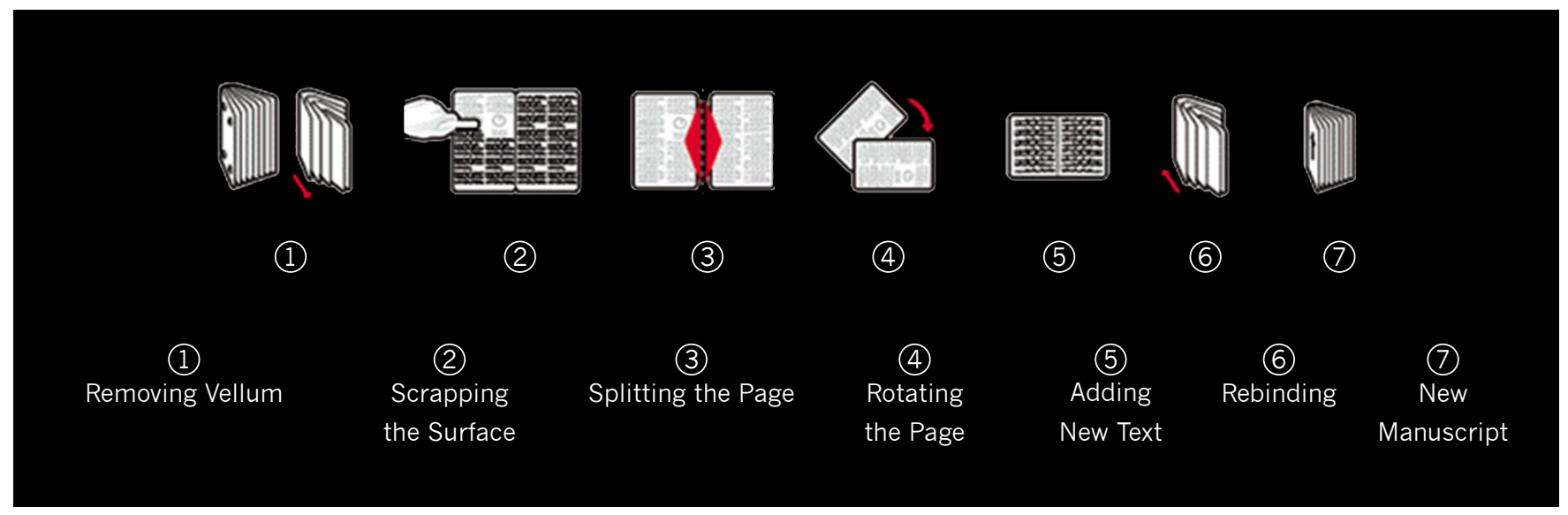

Fig. 2: The process of making a manuscript palimpsest.
Fig. 3: Archimedes' Palimpsest before the process of modern conservation.

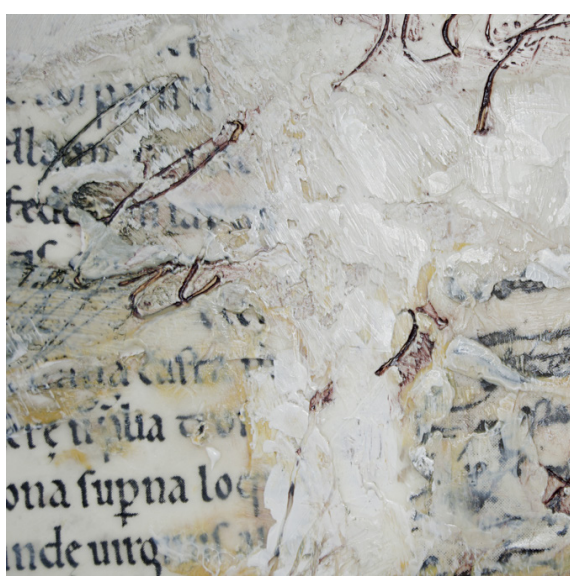

been affected or partially erased, and then over written by another; a manuscript in which later writing has been superimposed on earlier (affected) writing" (Oxford English Dictionary, 2015).

Between the seventh and the fifteenth centuries, the word palimpsest referred to the act of erasing earlier writing that occurred (Dillon, 2005). Palimpsests were found in scriptoriums or rooms of writing in monasteries where vellum was re-used. At the time, vellum was scarce and expensive to produce, and so it was expedient to write over deteriorating manuscripts or texts that had been rendered obsolete due to changing social, and cultural factors (Dillon, 2005).

The term 'palimpsest' as applied to manuscripts describes a condition where the original text was not completely destroyed or removed, but traces of ink were left behind. Before a new layer of text could be applied, the original text needed to be removed through a chemical process. This process included physically scraping the surface of the vellum (Dillon, 2005). New layers do not necessarily need to relate to previous layers. Over time, the previous layers of text would reappear due to the incomplete chemical process used to erase them. (Dillon, 2005). This reappearance revealed the previous layer to create a palimpsest that was interoperated (Kjerrgren, 2011). The act of removing an existing layer and creating a new one can also be described as superimposition or layering; this is a key concept in understanding what constitutes a palimpsest.

Only a few examples of vellum manuscripts that demonstrates palimpsest survive today. The most famous example is the 'Archimedes' Palimpsest'. This clear reuse of vellum exhibits an unintentional paradox where, due to economic conditions throughout history, it has been preserved (Verheij, 2015). What makes palimpsest manuscripts interesting today is that the imperfect process of erasing layers has left traces that can now be revealed though modern technology. These ghostly traces can be both tangible and intangible, which refers to the physical traces 
that can be interpreted or non-physical, which requires more research to understand the traces that remains. These traces can provide an insight into how people lived in the past. This historical record that can be read and interpreted is relevant to us today.

\subsection{Palimpsest as a Metaphor}

In 1845, Thomas de Quincey was the first to reintroduce the word 'palimpsest' into modern discourse. It was in his essay titled 'The Palimpsest' that he used the definite article to introduce and initiate the concept of the palimpsest. (Dillon, 2005; Bartolini, 2014). Up until 1845, the process of creating palimpsests involved layering and scraping off surface material to create paleographic manuscripts. Thomas De Quincey described the palimpsest as "involuted... the relationship between the texts that inhabit the palimpsest as a result of the process of palimpsesting and subsequent textual reappearance," (Dillon, 2005) while Sarah Dillon calls it "palimpsestuous... the structure with which one is presented as a result of that process, and the subsequent reappearance of the underlying script" (Dillon, 2005). Both words are acceptable with the adjectival form of 'palimpsest' being used to describe sets of relationships that come into being through the creation of a palimpsest. However, 'palimpsestuous' is preferred (Dillon, 2005). These relationships are important to how we can apply the term 'palimpsest' as a metaphor in other fields of study where it refers to something other than the revealing of text on a paleographic surface. It is important to keep in mind for our understanding today, however, that De Quincey and Dillon's definitions refer to the palaeographic palimpsest.

In the simplest terms, palimpsest as a metaphor refers to the transformation of a medium through time, a process that occurs around us constantly. It is the act of scraping off the surface and rewriting over it that is layered over time. Inevitably traces are left, both tangible and intangible, that make us aware of the many different layers that can influence us as designers.

As a metaphor, De Quincey describes the human mind in term of a palimpsest. He was in particular, interested by the failure of the first erasure and the reappearance of earlier writing (Dillon, 2005). Referring to this, he states:

"What else than a natural and mighty palimpsest is the human brain? Such a palimpsest is my brain; such a palimpsest, $O$ 


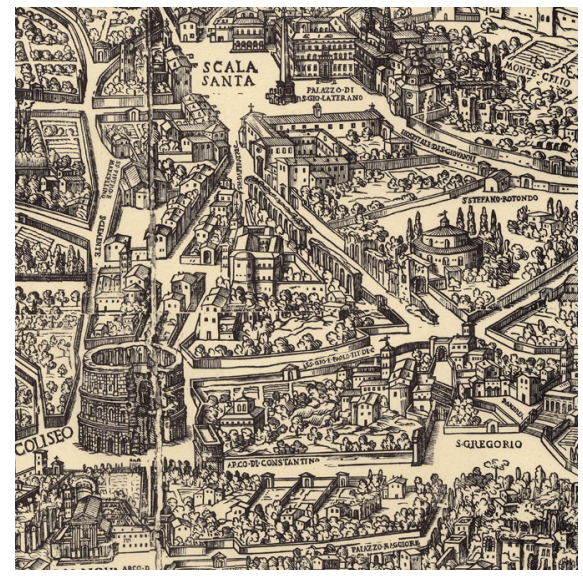

Fig. 4: Historic map of Rome, 1625, as Freud suggest it to be like a palimpsest. reader! is yours. Everlasting layers of ideas, images and feelings, have fallen upon your brain softly as light. Each succession has seemed to bury all that went before. And yet in reality not one has been extinguished" (De Quincey, 1998, p. 144).

The human mind, as a natural palimpsest, is able to layer experiences and memories on top one another without the loss of information. That leads to certain memories and experiences being repressed but never forgotten (Bartolini, 2014).

Similarly to how Thomas De Quinicy refers to the human mind as palimpsestuous, Sigmund Freud uses the metaphor of palimpsest to refer to human unconscious. In 'Civilization and its Discontent' Freud uses the analogy of Rome as a city with layered construction, a palimpsest, where earlier phases of construction exist below one another. These phases are buildings that are written over, partially erased and written over again, leaving traces behind that make up a layered city (Busa, 2008).

Freud suggests that, like the human unconscious, a city is a palimpsest. He tried to further comprehend the working of memory by comparing the city with the human unconscious. He states:

"Suppose that Rome is not a human habitation but a psychical entity with a similarly long and copious past- an entity, that is to say, in which nothing that has once come into existence will have passed away and all the earlier phases of development continues to exist alongside the latest one..." (Freud, 1961, p. 17).

This suggests to Freud that, like a city, the human unconscious features previous existences layered on top of one another, with the most recent layer representing the most recent experience (Bartolini, 2014). The difference between the city and the human unconscious as metaphors for a palimpsest is that the mind is able to store memories and experiences (Bartolini, 2014). These can be repressed but not forgotten.

The comparison of the human mind to a palimpsest by De Quincey and Freud has shown the potential of the concept to be applied to other disciplines. Freud's analogy of Rome suggests the possibility of engaging in a dialogue with the traces that are left behind. That these traces can be tangible or intangible allows for complex relationships between the past, present and future that can be investigated. Furthermore, these sets of relationships allow for a narrative to be revealed. De Quincey was not the first to use 'palimpsest' as a metaphor. However, his fascination of the concept marked the beginning of the use of the metaphor with application to such disciplines as archaeology, psychology, urbanism and landscape and architecture from the mid-19th century to the present. 


\subsection{Palimpsest as Archaeology}

In archaeology, the term 'palimpsest' is used to describe a city that features multiple layers of activity. Some archaeologists believe that the palimpsest present a handicap to a site as it necessitates reliance on an incomplete record of material traces (Baily, 2006). However, what material traces that do remain can be interpreted or read. Applying different techniques such as excavations, mapping, the restoration of artifacts and the studying of material traces can help us to understand the narrative of the site. The accumulation and superimposition of successive layers creates an opportunity to study the various scales and type of palimpsest that exist within archaeology.

Geoffry Baily, archaeology professor at the University of York, describes palimpsest as applied to archaeology as the superimposition of successive layers where earlier layers were destroyed or reworked, with traces being left behind in new layers (Bailey, 2006). Archaeology is an exercise in interpretation or as Paul Ring (2008) calls it, 'reading':

"Archaeology is in itself an exercise in reading...the field study, the hypothesis from the laboratory and supposition from theory and interpretation to script this story of human past. This story is not ready made, it is a story formed of fragments which require reading." (p. 2).

'Reading' is an exercise to discover narratives of the past and requires some use of imagination to interoperate and understand the origins and purposes of material traces. Material traces are imbued with the events and memories of peoples and with the mechanics of societies (Ring, 2008). At times, the material traces and the layers of activities can intertwine, making it difficult to separate each narrative. With this in mind, Bailey was able to create a series of categories or types of palimpsests that exists within archaeology.

The concept of the palimpsest in its most extreme form involves the total removal of earlier traces of activities except the most recent (Bailey 2006). However, other aspects of palimpsest are less extreme and require the reworking of existing material traces to transform them into successive activities that will themselves be partially preserved (Bailey, 2006). Baily suggest there are three types of palimpsest; true palimpsest, cumulative palimpsest and spatial palimpsest.

True palimpsest is the complete removal of all earlier layers of activates except for the top most layer, with no material traces being left 

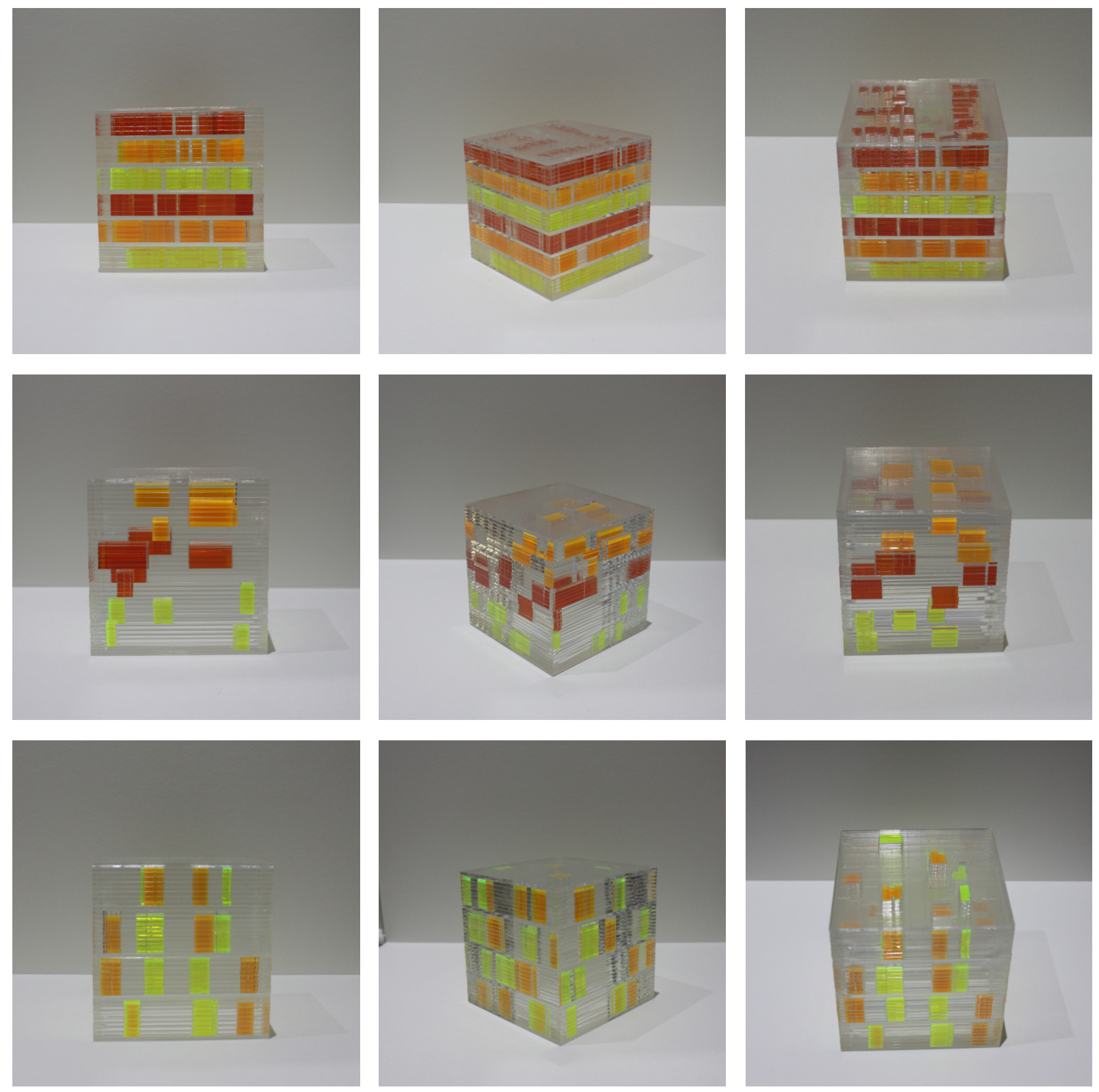

Fig. 5: Architectural objects showing true palimpsest (top row), cumulative palimpsest (middle row), and spatial palimpsest (bottom row). 
behind (Bailey, 2006). As new layer of activity occurs, the successive layer is completely removed. Figure 5 (top row) is an example of my exploration of a true palimpsest at a city scale. Each layer represents a specific time while each colour represents a specific activity. As new activity occurs, the previous layer is removed and a new layer is created. Through this exploration, I have realized that true palimpsest can occur at various scales, from small architectural objects and buildings to cities and landscapes.

Cumulative palimpsest refers to a situation where layers of activity remain superimposed one on top of another without loss of activity (Bailey, 2006). Each layer is neither removed nor destroyed but can be reworked into new layers. Figure 5 (middle row) shows the following architectural object as an exploration of cumulative palimpsest. Each layer represents a specific time while the colour represents different activities. Over time, new phases of activities occur and are superimposed one on top of another.

Spatial palimpsest is the accumulation of different layers that are displaced from their proper temporal layer (Bailey, 2006). Each of the material traces are further displaced by intertwining them with different layers of activities. Figure 5 (bottom row) shows the following architectural objects as an exploration of spatial palimpsest. Each layer represents a specific time, while the colour represents different activities. Each of the material traces are intertwined with different layers of activities, making it harder to distinguish where each period begins and where it ends.

Bailey has defined a range of palimpsest that can exist in any archaeological site, depending on the area of the site and the time span that it covers. It is important to note that the area of the site and the time span that is being studied are important factors when interpreting or reading the archaeological site (Kjerrgren, 2011). It is the consideration of these factors that make the narrative either broad or specific.

The material traces that are left behind within the layers of activities are tangible. Attached to these are the events, memories and values of people and societies. Intangible meanings gradually accumulate and changes associations over time until they are abandoned or forgotten (Bailey, 2006). The palimpsest of meaning does not necessarily refer only to tangible objects, sites or buildings; it can indicate the ideas, values and traditions that are associated within a place.

Palimpsest in archaeology is complex however, Bailey has presented an alternative to the traditional discourse. Bailey believed that palimpsest is a universal phenomenon that occurs naturally (Bailey, 2006). It encompasses both tangible and intangible objects, sites or landscapes. 
Meaning accumulates and changes that requires reading or interpretation to understand its origins and purpose. Some imaginative strategies are required to understand the relationships between the layers of the past, present and future.

\subsection{Palimpsest in Urbanism and Landscape}

In urbanism and landscape, the term palimpsest is used as a metaphor to describe how cities are constantly accumulating layers that influence how we build and design. It can become challenging when dealing with older cities such as Rome or London where there are many more layers of activity than in contemporary cities like New York or Toronto. The contrast between the old buildings and new ones creates a sense of place and identity for its inhabitants. Urbanists and architects such as Aldo Rossi and Kevin Lynch use the concept of palimpsest to describe the material traces that are left within cities and landscape.

Cities and landscapes are constantly being reused; the surface is erased and rewritten to meet the needs of inhabitants. Andre Corboz (1983) suggests 'reading' cities and landscape as a palimpsest in the same way that archaeologist do, in order to understand the different narratives of a city:

"The land, so heavily charged with traces and with past readings, seems very similar to a palimpsest. Every land is unique, whence the need to 'recycle,' to scrape clean once more (if possible with the greatest care) the ancient text where men have written across the irreplaceable surface of the soil, in order to make it available again so that it meets today's needs before being done way with in its turn" (p. 33).

Similar to Corboz's presentation of the cities and landscapes as an accumulation of stratified layers, Aldo Rossi believes that cities are constructed in layers over a long period of time. "One need only look at the layers of the city ..."(Rossi, 1982, p. 22) through the lens of an archaeologist when layers of the past can be revealed.

An example of palimpsest within a city is in Toronto at the intersection

Fig. 6: (top) The view of Yonge and Wellington Street showing the city as a palimpsest Fig. 7: (middle) The view from Wellington Street, North Facade of Front and Wellington Street. In 1904, a fire occurred that erased a large section of the downtown core. What remained were ruins and shells of buildings. Few buildings left untouched by the fire, over the years, land freed up by the fire allowed for larger and taller buildings to 

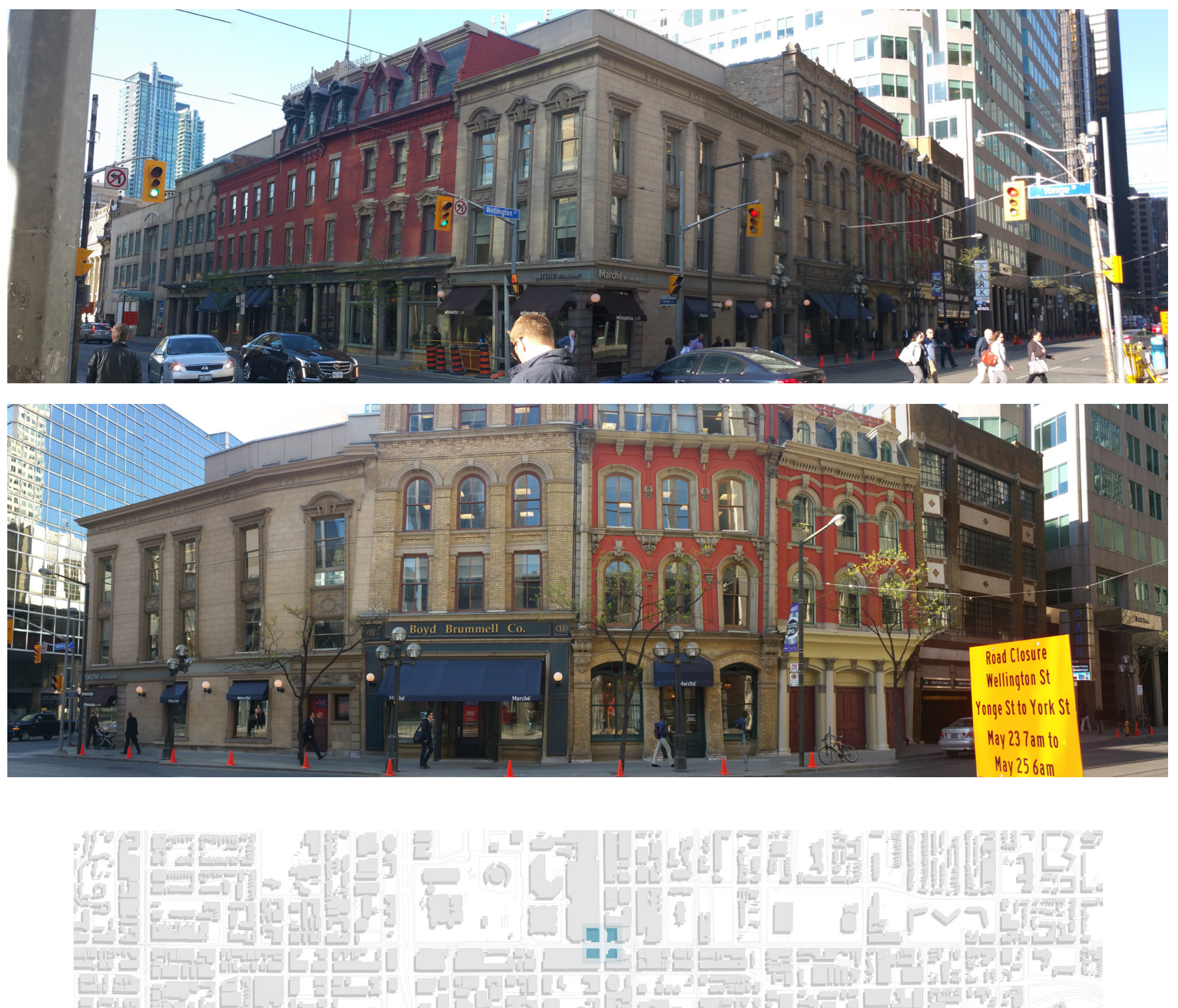

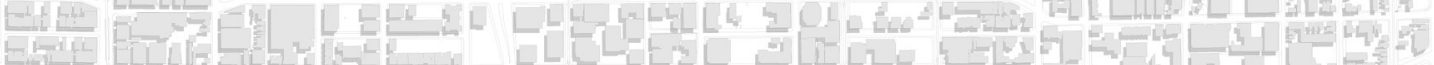

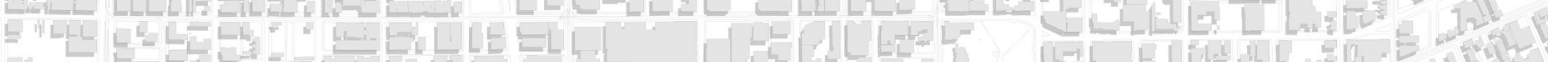
LLE

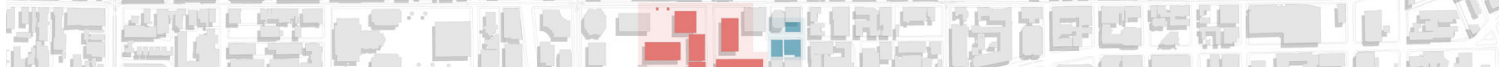
LLL

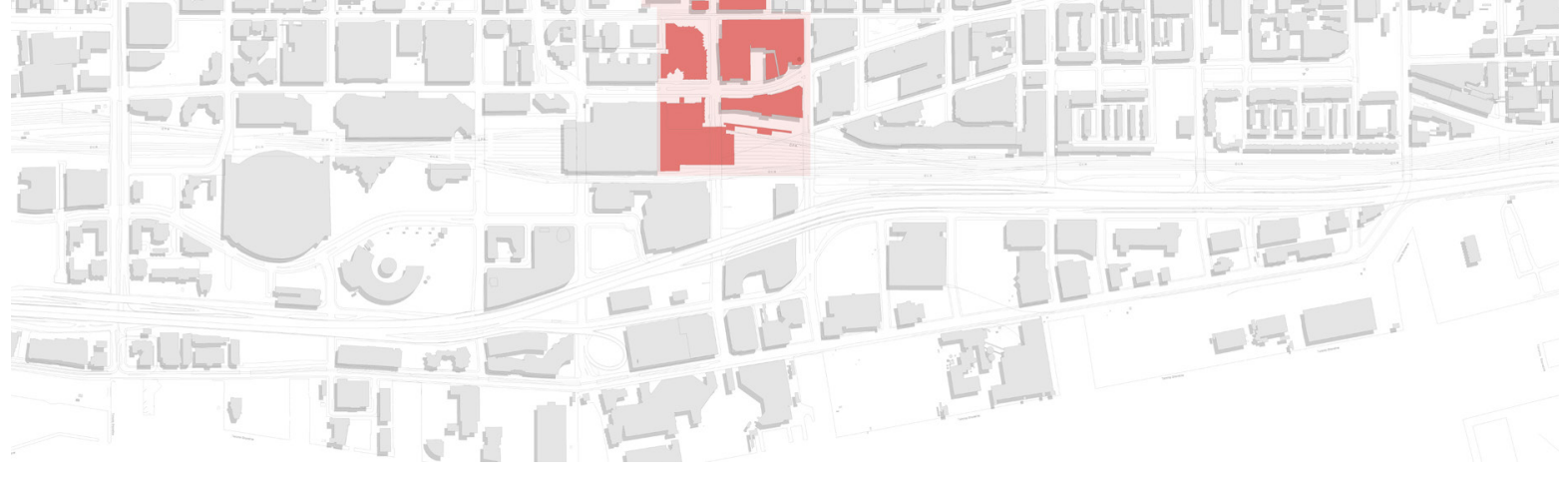


be built. The new buildings sit in between 19th century buildings that remained untouched by modernity. This contrast between the old and new reveals the city as a layered construction.

Rossi viewed the city as a material artifact, "a man-made object built over time and retaining the traces of time" (Rossi, 1982). The layers that make up the material artifact are an accumulation of the inhabitants needs and feature artifacts, objects, buildings and collective and personal memories. Kevin Lynch also provides a more scientific approach to the past through archaeological investigations that dissect a city to analyze the fragments of the traces that remain (Lynch, 1972). The transformative nature of a city that both Rossi and Lynch discuss features traces that can be read and interpreted. These traces are objects, structures, plot sizes, land use, crop marks and circulation patterns (Lynch, 1972).

Cities and landscapes have been constantly rewritten and erased by their inhabitants as far back as ancient times. What remains is a layered city, a palimpsest, where earlier phases of construction influenced cities' designs for the future. Their juxtaposition of the old and new, past and future allows for cities to create a sense of place and identity where people can relate. The conception of cities and landscapes as palimpsest can provide a sense of meaning and depth that people can connect to.

\subsection{Palimpsest in Architecture}

Architecture uses the concept of palimpsest as a metaphor for the reuse and layering of old and new elements of buildings. The use of the term suggests that buildings are either reused, altered, and then adapted to new functions, or are abandoned and demolished by the people who inhabit them. What remains are traces left behind, a palimpsest, that can be read to reveal the past. The metaphor also suggests that, since we are talking about layers of history, such concepts as preservation, conservation, adaptive reuse and rehabilitation should be considered. When dealing with palimpsest, there is no prescribed approach. Architects have long debated what approaches are appropriate when dealing with multiple layers of activity within a building.

When considering preservation, conservation, and adaptive reuse architects such as John Ruskin and Eugene Viollet-le-Duc come to mind. John Ruskin believes that, when it comes to existing buildings, one should leave them alone: any alteration or even "[restoration] is a Lie from beginning to end" (Ruskin, 1849, p. 186) and affects the building's 


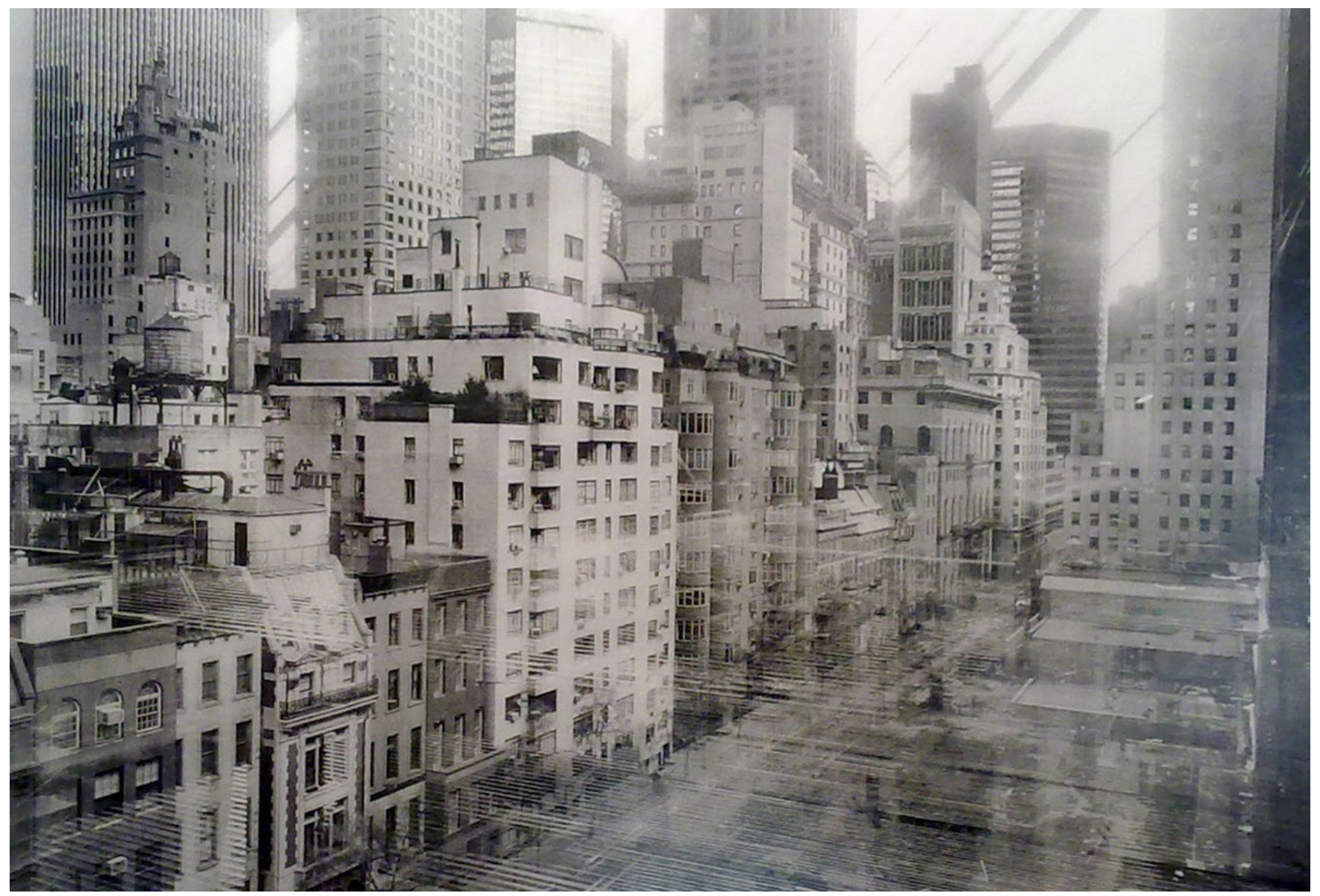

integrity, meaning and value. In more recent discourse, Peter Eisenman and Bernard Tshumi have proposed the use of palimpsest as a means of informing a design so that it works with existing buildings and site. New interventions must consider the palimpsest in order to be successful. According to Paul Ring (2008):

"[Palimpsest in architecture] is an approach to the existing that goes beyond a celebration of architectural style and doctrine but concentrates on narrative and imaginative. This approach removes the act of reuse from the mechanism of conservation and preservation of built heritage and elevates it into that of literary and poetic and the artistic. It is a process of precision, of distinct controlled acts, akin to the archaeologists approach to removal of sediment and sand" (p. 2).

Therefore, palimpsest in architecture is the process of reworking and demolishing existing buildings and leaving traces behind. It can be interpreted and used to influence future designs. The most successful interventions take into account the traces that remain, the past or palimpsest, as a means of finding a balance of the old and new. Design today needs to pay attention to spatial, poetic, artistic, imaginative and philosophical values, which are lacking in many of today's buildings.
Fig. 9: A Long exposure of the city by Michael Wesely, capturing a place over time examining the city as a palimpsest 
In architecture, interpreting the traces that remain is a good starting point for new designs. Peter Eisenman uses the traces to inform such projects as the Wexner Centre in Ohio, and the University Art Museum at California State University. The revelation of palimpsest in his designs was a means of breaking away from modernist traditions and language by referring to the past. According to Eisenman, he considers both tangible and intangible traces:

"Any site contains not only presences, but the memory of pervious presences and the immense of a possible presence. The physical difference between a moving thing (dynamism) and a still one (stasis) is that the moving one contains the traces of where it has been and where it is going. The induction of these trace, or condition of absence, acknowledges the dynamic reality of the living city" (Eisenman, 2004, p. 207).

Since the 1980s, Eisenman has been fascinated by the idea of revealing the traces that are left behind, the palimpsest, and by revealing the relationship between layers. For example, in 1986, University Art Museum at California State University, Eisenman designed "the building as an architectural artifact, a palimpsest of its own history" (Eisenman, 1994, p. 132). He allowed the architecture to "tell a story, a narrative... the important condition that is marked by the architecture" (Eisenman, 1994 , p. 132). The design relied on layering different traces at various scales on top of one another (Bedard, 1994, p. 138). This allowed the history of the site to inform the design, creating a building that is seen as "layered and shifting, continually exposing different surfaces" (Eisenman, 1994, p. 132).

Eisenman believed that the overlapping different historical layers can reveal hidden relationships that were not previously evident. Tracing layers of palimpsest allows for the design to be interpreted by its users. Future users can reinterpret the site and add new narratives to it. Eisenman (1994) continues to explain:

"The idea was to imagine the site 100 years after the university campus was founded, and 200 years after the period of the gold rush. The idea was for it to be possible for someone who stumbles upon the site in 2049 to learn about the culture that existed for the 200 years previously to discover by reading the buildings" (p. 131 -132).

The University Art Museum was successful in layering different traces to reveal the past. Eisenman's approach to palimpsest seems to rely on its metaphorical meaning as a guide to conceiving the design. Bernard Tschumi, on the other hand, believes that the palimpsest approach was 

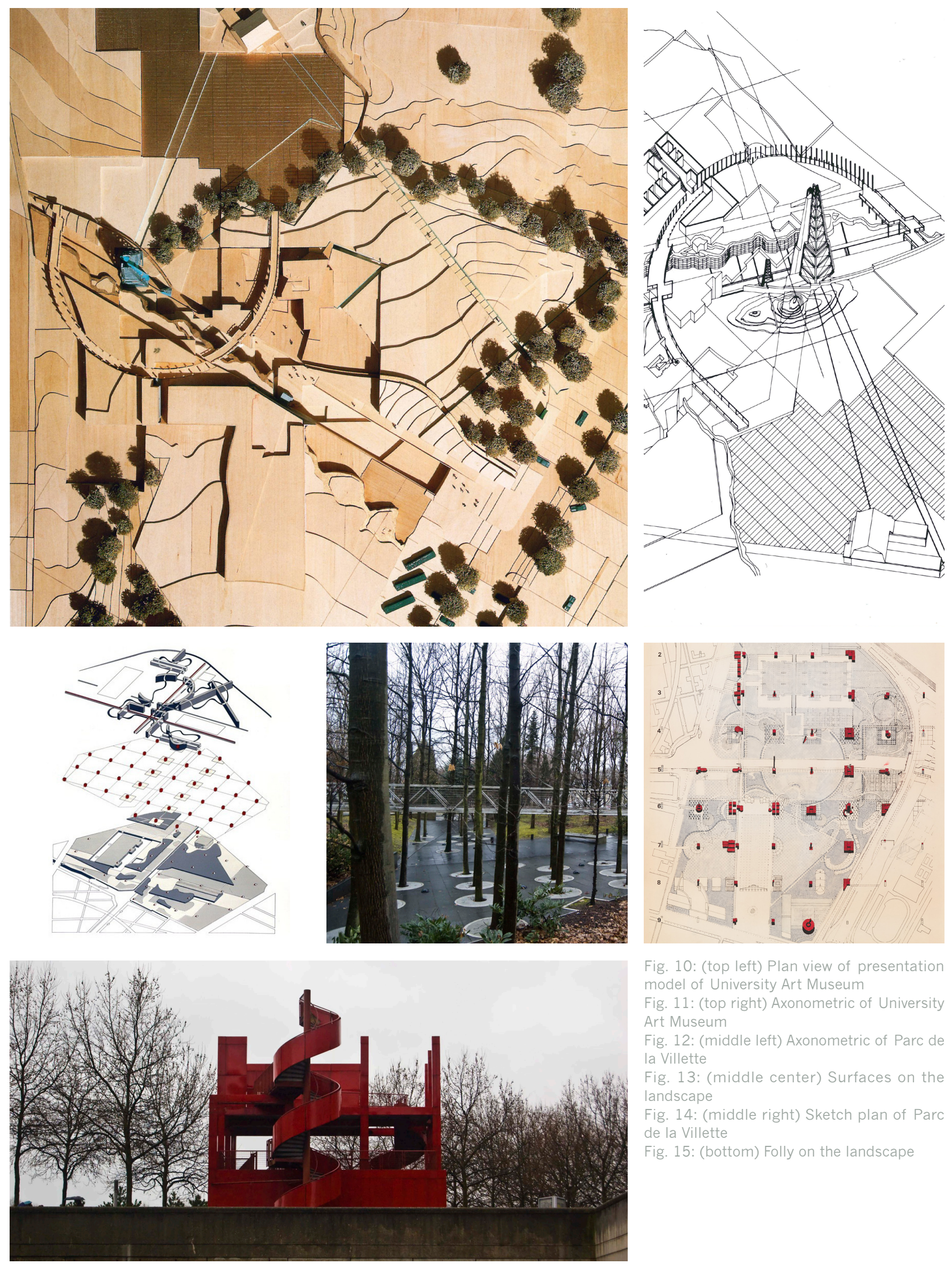

Eig. 10: (top-left) Plan view of presentation model of University Art Museum

Fig. 11: (top right) Axonometric of University Art Museum

Fig. 12: (middle left) Axonometric of Parc de la Villette

Fig. 13: (middle center) Surfaces on the Fig. 14: (middle right) Sketch plan of Parc de la Villette
Fig. 15: (bottom) Folly on the landscape 
too abstract when designing. Therefore he decided instead of using palimpsest as a method, he decided to overlap different systems such as points, lines and surfaces to respond to the existing context. He uses this approach in projects like Parc de la Villette in Paris and the Acropolis Museum in Athens.

When Tschumi won the commission for the Parc de la Villette, his design featured a system of points, lines and surfaces that were superimposed on the landscape. He believed his approach was more appropriate than was the use of palimpsest as the focus of the design. He explains there are two approaches that can be used in a design of this scale, first:

"When confronted with an urbanistic program, an architect may ... deconstruct what exist by critically analyzing the historical layers that proceeded it, even adding another layers derived from elsewhere - from other cities, other parks (a palimpsest)" (Tschumi, 1994, p. 191-192);

and second,

"Search for an intermediary - an abstract system to mediate between the site (as well as all given constraints) and some other concept, beyond city or program (a mediation)" (Tschumi, 1994, p. 191-192).

At the end, Tschumi decided to ignore the palimpsest that existed, he explained that:

"The palimpsest was not pursed, for its inevitably figurative or representational components were incompatible with the complexity of the programmatic, technical and political constrains that could be foreseen" (Tschumi, 1994, p.198).

At an abstract level, there is a palimpsestuous attitude in the design where the points, lines and surfaces are layered over each other to create new relationships with the existing landscape. These layers become part of the history of the site, continuing to add onto the top layer of the site creating new palimpsest. At the end, the aim was to construct a new complex architecture organization with points, lines, and surfaces, rather than using the tradition rules of composition, hierarchy and order for Parc de la Villette (Tschumi, 1994).

Eisenman and Tschumi stress the importance of palimpsest during the design process. They seek to establish a narrative by revealing the palimpsest that already exists on a site. They understand that although 
a building's site is never a clean slate, the relationships between layers does not necessarily need to influence the design; however, it should allow for patterns to emerge that are specific to the space. There are different ways to use palimpsest in architecture.

\subsection{Memory in Palimpsest}

Architects, designers and planners are constantly rebuilding our environment; this ongoing process through time links the past, present and future. In order to avoid erasing the past, we need to first reveal the tangible and intangible layers of a site. Some places can be easily remembered while others we forget. It is the places that remain with us that simulate our unconscious mind. In archaeology, urban cities, landscapes and architecture, tangible traces that remain make it easier to read a site. Intangible traces-ideas, values, traditions and individual or collective memories-require more investigation and interpretation.

Memories can be attached to or associated with objects, artefacts, buildings, sites and landscapes (Yates, 1966). It is important to reveal these memories since they can be easily forgotten and lost through time. Places that are associated with memories remain deep inside our subconscious and in fact become mnemonic devices for those places. This process is called the art of memory or as the Greek calls it 'ars memorativa'.

Frances Yates reintroduces the lost art of memory in her book called The Art of Memory. She starts off with:

"Few people know that the Greeks, who invented many arts, invented an art of memory which like their other arts, was passed on to Rome whence it descended in the European tradition. This art seeks to memorise through a technique of impressing 'place' and 'images' on memory. It has usually been classed as 'mnemotechnics', which in modern times seems a rather unimportant branch of human activates. But in the ages before printing a trained memory was vitally important; and the manipulation of images in memory must always to some extent involve the psyche as a whole" (Yates, 1966, p. xi).

Place is important to memory since they can evoke images that help us recall events and people. The Greeks were able to master memory techniques with the use of 'mnomincs', the imprinting of memories within a place to help evoke other memories, experiences or ideas (Yates, 1966.) 
In order to start Yates (1966) explains:

"The first step was to imprint on the memory a series of loci or places. The commonest, though not the only, type of mnemonic place system used was the architectural type... In order to form a series of place in memory... a building is to be remembered as spacious and varied a one as possible, the forecourt, the living room, bedrooms, and parlours, not omitting statues and other ornaments with which the rooms are decorated. The images by which the speech is to be remembered... are the placed in imagination on the places which have been memorised in the building... the method ensures that the points are remembered in the right order, since the order is fixed by the sequence of places in the building" (p. 4).

Mnemonics are useful for the recollection of specific events, ideas or people and involve spaces that hold, or are imbued with, memories and experiences. Yates explains there are two types of memory: natural memory and artificial memory. Natural memory refers to how one remembers events, images or experiences, while artificial memory involves the reshaping of natural memory so that certain events, images or experience can be recalled in a new way (Yates, 1966). Memorials, ceremonies and events are a type of mnemonic device that uses natural and artificial memory to help convey, recall and remember certain memories and experiences.

Some memories involve moments that are associated with a specific place, so that people come to have an emotional attachment to the place itself. Places can conjure up nostalgic feelings related to personal experiences. Certain events such as rituals and celebrations can provide a sense of place and time. Some places have an unexplainable attraction for us and create a sense of nostalgia that makes us want to return to them (Bloszies, 2012; Verheij, 2015; Jackson, 1994). Donlyn Lyndon

Fig. 16: Cascading Gorge, Ithaca New York

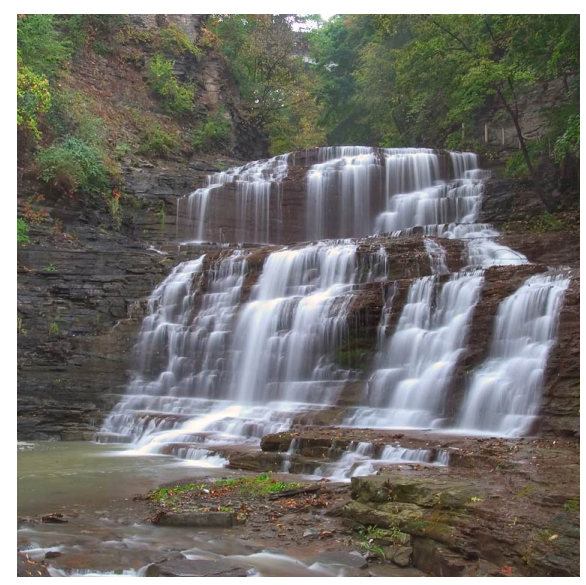
(2009) states that "Place... refers to a space that can be remembered, that we can imagine, hold in the mind and consider. They are territories that can be lived in with special satisfaction because they resonate with association that engage our interest" (p. 63). The meanings of places change as events, celebrations and rituals occur. We experience buildings and spaces in our day-to-day life; they resonate and gives us a sense of unity and continuality (Verheij, 2015).

Memories can be layered onto one another, can accumulate and change over time even if they are intangible and not represented by physical remains. People project their memories and experiences onto a particular spaces and become attached to these spaces (Treib 2009). Therefore, "...memory needs to be understood as the trace of all that has 


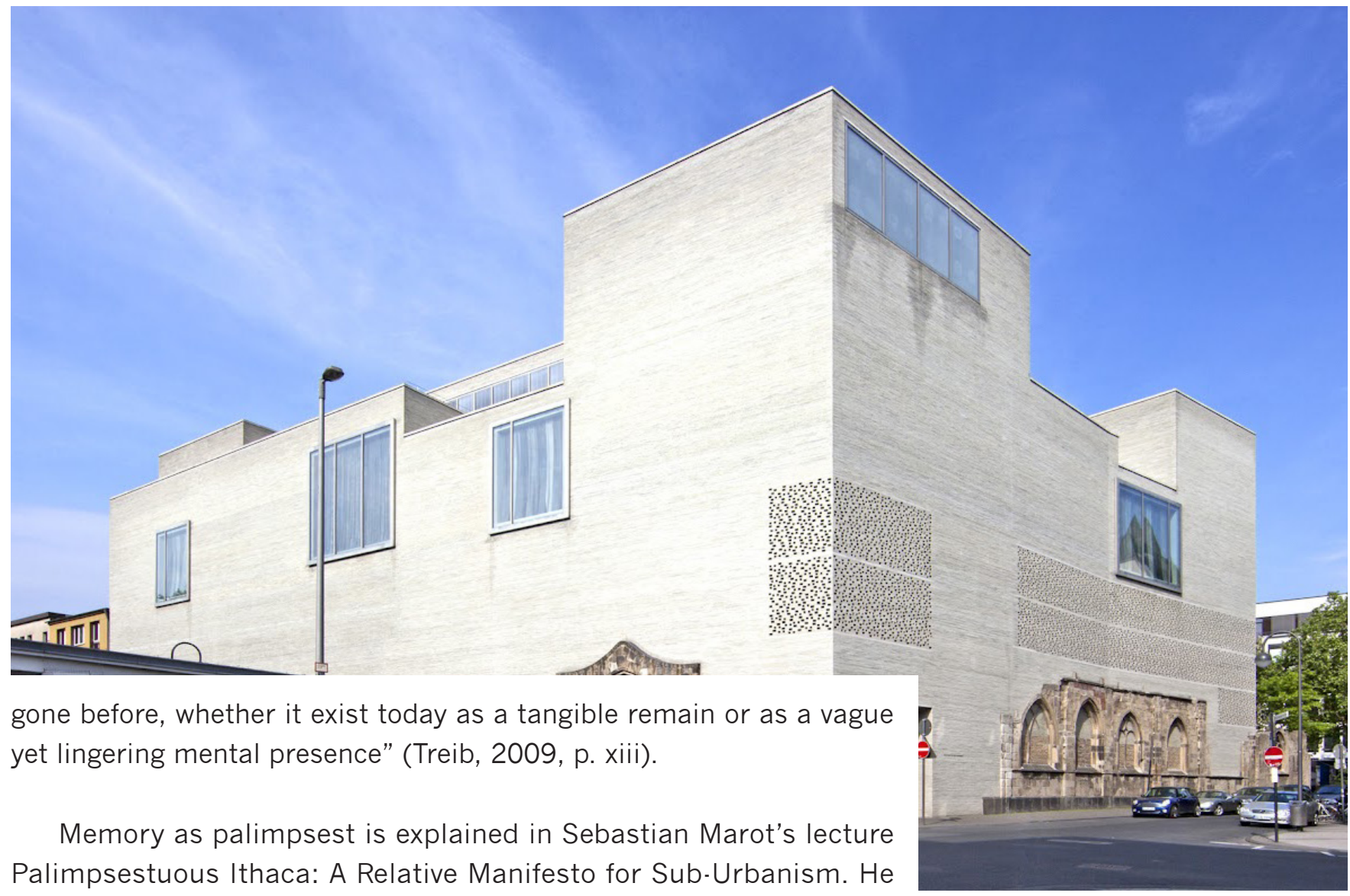
explains that palimpsest is present in both the physical and non-physical (Marot, 2010). For example, Ithaca New York is a landscape that has Fig. 17: Kolumba Museum in Cologne by Peter Zumthor examples of stratification, superimposition and layering traces dating back thousand of years (Marot, 2010). By visualizing memory with ideas of archaeology, stratification, superimposition and layering traces, it is possible to use memory as palimpsest in architecture.

Peter Zumthor's Kolumba Museum in Cologne is an example where memory as palimpsest is used within a design. The site of the museum has always had a historic meaning to the city. Since the Roman Empire settled in the city, a church was built on the site where the museum is located. The church was eventually rebuilt into a gothic cathedral. By 1943, after the bombings of World War II, the gothic church was let in ruins. Peter Zumthor had the task to reconcile the many layers that exists. The museum manages to add on to the narrative of the site revealing the fragments of history.

There are no windows in the façade, except for a few perforated openings to allow light in. The ruins were left in its found condition where they are preserved as an archaeological excavation. A pathway weaves though the site, leading visitors through the ruins. The museum built over the ruins, with slender concrete column supporting an atrium space. By layering over the ruins, the traces of the church become a layer of 


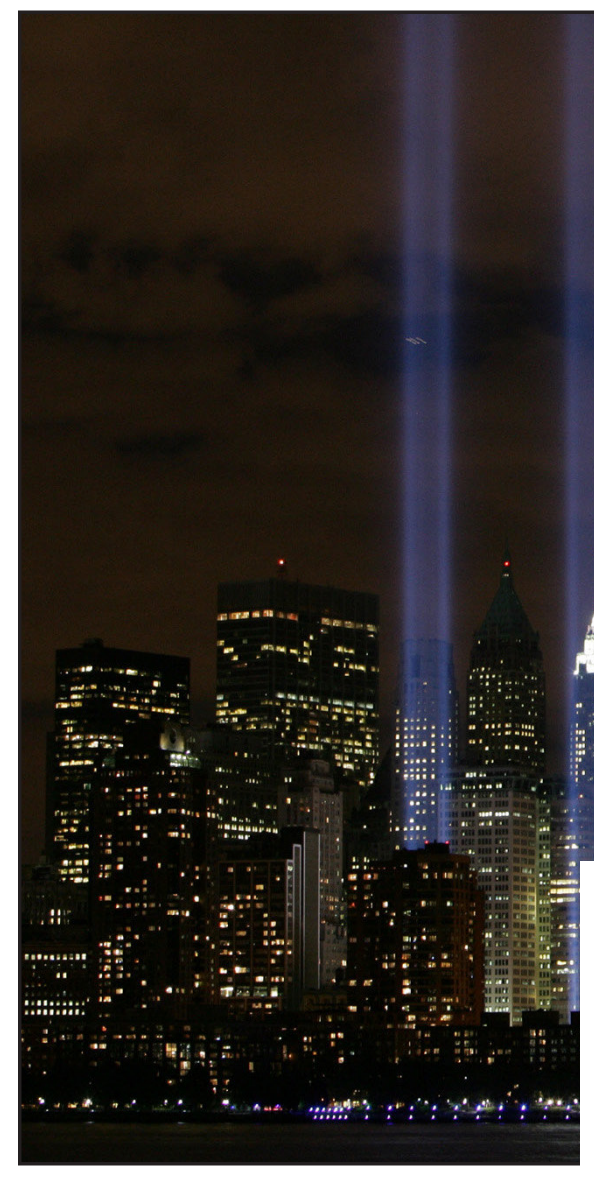

Fig. 18: New York skyline with 'Towers of Light' fill the sky where the World Trade Centre once stood. The lights traces over the void where the towers once stood representing the intangible meaning and layers

\section{A}

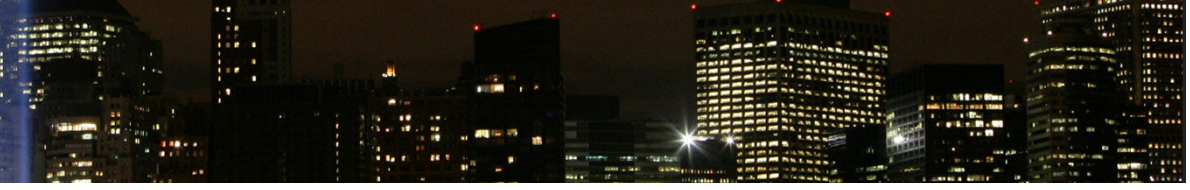

memory (Verheij, 2015). The buildings follow the original design, thereby extending the history of the site. Visitors are able to feel the emotion of the site as they proceed through the building.

Cities, like architecture, have the capacity to reveal memory and experience. Cities are constantly reshaping their own history even as their elements are replaced, demolished or reworked into something new. Sebastien Marot, along with Aldo Rossi, believed that cities had the potential to contain the collective memory of their people. People use places as mnemonic devices for events associated with them. Aldo Rossi explains that:

\begin{abstract}
"One can say that the city itself is the collective memory of its people, and like memory it is associated with objects and places. The city is the locus of the collective memory. This relationship between the locus and the citizenry then becomes the city's predominant image, both of architecture and of landscape, and as certain artifacts become part of its memory, new ones emerge. In this entirely positive sense great ideas flow through the history of the city and give shape to it" (Rossi, 1982, p. 130).
\end{abstract}

The architecture of the city, both tangible and intangible, can accumulate significant meaning. Memories are the soul of the city; they contain the city's distinct and defined character. Architecture, monuments and public spaces play a role in how we experience the past or palimpsest though events traditions and ceremonies. As Andreas Huyssen has observed, the void left behind by the World Trade Centre in 2001 in New York City recalls the horrific events that occurred within that 
space (Huyssen, 2003). Even though the physical traces of the World Trade Center are gone, left behind are memories of sorrow and loss and act of terrorism to the Western Nations' ideals such as capitalism and freedom (Huyssen, 2003). This collective experience of sorrow and loss adds to a space that was already significant for a long tradition of ceremonies and events. There, the past is revealed through a palimpsest with several layers.

Objects, buildings, sites and landscapes come with memories. They can serve as mnemonic devices that help record and transmit history. While the art of memory is basically about remembering past experiences, the imprinting of these experiences onto a place can make them more vivid and accessible. Spaces can be either physical constructs or voids; both are able to accumulate significant meaning. It is only when collective memories and experiences are passed on and remembered that they become history. It is through the act of tracing that the memories in the palimpsest are revealed. 
Section 2.0

Preservation 


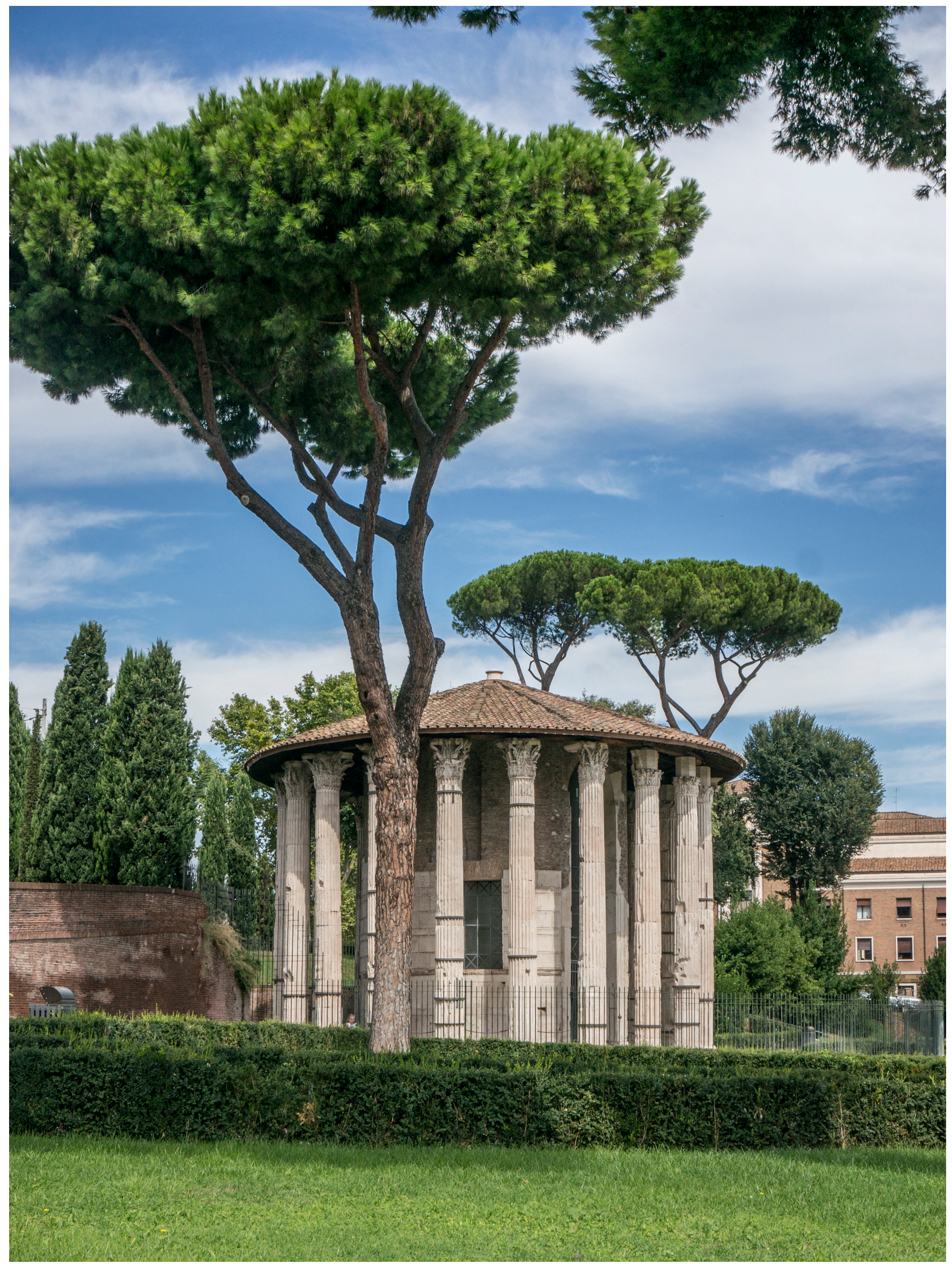




\subsection{Introduction}

We are constantly reusing and reworking our environment, whether it consists of buildings, structures or landscapes. This reworking features multiple layers of activity where traces of materials remain. Like a palimpsest, these traces may be tangible or intangible; both types can be interpreted or read. In the previous section, the concept of palimpsest in archaeology, urbanism and landscape, and architecture was explored. It demonstrated that palimpsest is a metaphor for the superimposition of successive layers, where the writing over, erasing and re-writing leaves traces behind that can be read or interpreted. The traces that remain can inform us as designers how to create interventions that balance both the old and new.

The most successful architectural interventions will have a substantial understanding of the history of existing buildings (Brooker and Stone, 2004). This leads to the consideration of preservation, conservation and adaptive reuse, which are not new concepts. Existing buildings throughout history, for example the Roman Arena in Nimes, France or the Bath of Diocletian in Rome, and even contemporary buildings like the Nueus Museum in Berlin have been altered, restored or reused into something new. Working with existing buildings through preservation, conservation and adaptive reuse presents a creative and fascinating challenge for successfully bringing the past together with the future in unexpected ways. This section will explore the history of preservation in the discourse of architecture and how palimpsest can be used as a method of revealing the past that reveals and preserves the layers that remains.

Opposite

Fig. 1: Temple of Vesta also known as Round Temple by the Tiber constantly being adapted, altered and restored several since ancient times. 


\subsection{The Beginning of Preservation}
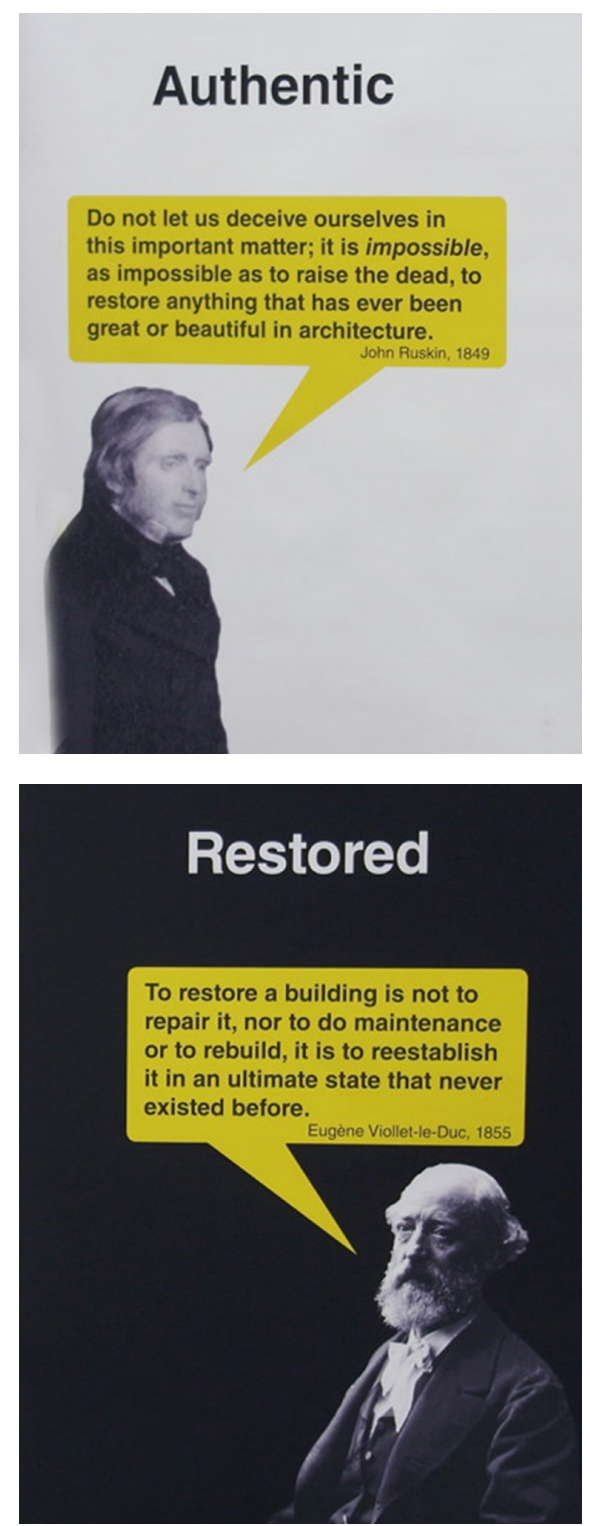

Fig. 2: (top) OMA Venice Biennale 2010 Cronocaos, John Ruskin's attitude towards preservation

Fig. 3: (bottom) OMA Venice Biennale 2010 Cronocaos, Viollet-le-Duc's attitude towards preservation
Preservation as we understand it today began in the 1790's when the first law of preservation was defined after the French Revolution (Koolhaas, 2014). It advocated awareness of history and reminded everyone of its importance at a time when history itself was being made and old ways were being discarded and replaced with new ones. Another important moment was in 1877 in Victorian England when there was a second preservation proposition (Koolhaas, 2014). However, the act of preservation itself dates back to antiquity. Romans constantly restored and adapted important monuments such as the Temple of Vesta to reflect current political and cultural practices (Semes, 2009). Medieval builders however, were crude in their efforts to preserve. They would disassemble abandoned buildings and reuse the space bluntly in new ways (Semes, 2009). It was not until the 1900's that preservation adopted a more objective approach to the close study and analysis of historic buildings.

Architects and theorists such as John Ruskin and Eugene Emmanuel Viollet-le-Duc debated preservation and what it meant to restore a building. John Ruskin believed that we have a responsibility to safeguard the historic and documentary significance of buildings and monuments (Semes, 2009). Existing buildings, whether they are old or historic, must be preserved in their present conditions. Viollet-le-duc saw existing buildings as living structures capable of adapting to meet needs other than those for which they were originally built (Semes, 2009). He argued for the restoration of older buildings to an 'ultimate state' of its original condition.

There are a number of different approaches to preservation as both Ruskin and Viollet-le-Duc has pointed out. According to Ruskin (1849):

"Neither by the public, nor by those who have the care of public monuments, is the true meaning of the word restoration understood. It means the most total destruction, which a building can suffer: a destruction out of which no remnants can be gathered; a destruction accompanied with false description of the thing destroyed. Do not let us deceive ourselves in this important matter; it is impossible, as impossible as to raise the dead, to restore anything that has ever been great or beautiful in architecture" (p. 194).

Ruskin would not have supported any alteration, restoration, reuse or addition to the original form. He firmly believed that restoration would 

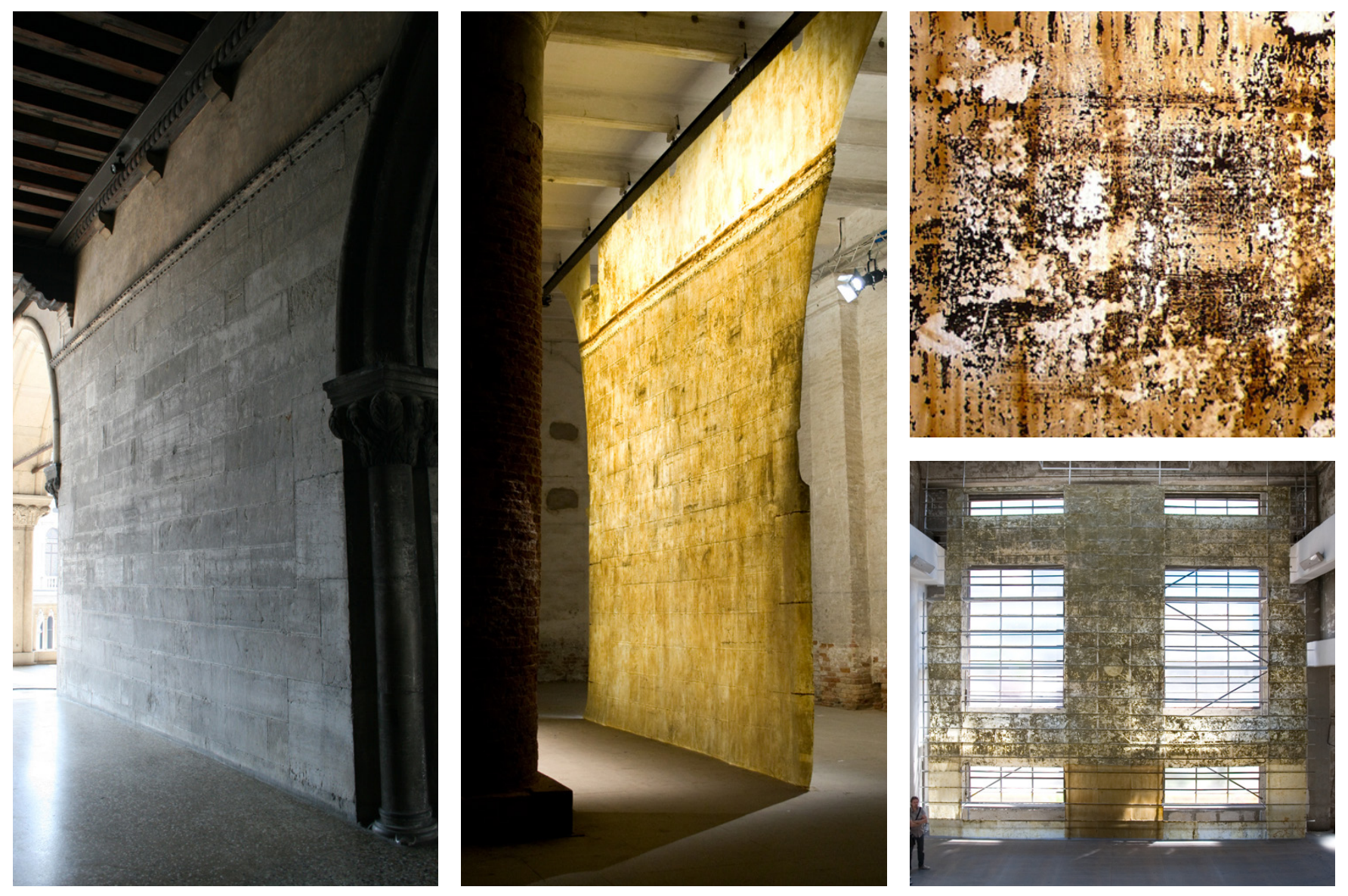

involve the total destruction of a building and its integrity. Restoration should be done only for the maintenance of a building; additional unnecessary changes should not be made. He rejected any future interpretation of the maintenance of buildings. He wanted buildings to be artifacts or documentations of the past rather than structures that could be reused by the public. His 'hands-off' approach reduces the role of the architect to that of stewards of historic buildings (Semes, 2009).

Every aspect of a building must be preserved, even the layers of dust and dirt. This layer of dirt or 'time stain' has value, which is intrinsic to the building's history (Raskin, 2011). Ruskin believed that the accumulation of dust needed to be preserved; it represented age and age meant authenticity and character (Raskin, 2011). This concept of natural layering or palimpsest inspired Jorge Otero-Pailos an architect and preservationist, to create an installation called 'The Ethics of Dust' after Ruskin own 1865 book 'The Ethics of the Dust' (Raskin, 2011).

Part of the preservation process requires cleaning the building to return it to its original condition; this step has been a central part of the preservation process since the 19th century (Raskin, 2011). Cleaning was not only essential to maintaining the appearance of the building but was also a way to uncover the original intent of the design (Raskin, 2011). Otero-Pailos critiques this step as he contributes to the ongoing

Fig. 4: The original wall cleaned, (top left) and its pollution on latex (top middle) at 'The Ethics of Dust, Venice, 2009' Fig. 5: (top right) Detail of Pollution 'The Ethics of Dust

Fig. 6: (bottom right) The original factory wall in the process of being cleaned 
debate regarding preservation. His position is that dust and dirt should be preserved as a means of showing a building's age (Raskin, 2011), and to give the building the authenticity and legitimacy of a historic place. Some may perceive dirt only as filth that distorts the architecture from its ideal condition. Otero-Pailos, however, believes that dirt memorializes specific moments in history; it was there when important events like industrialization, revolution, or famine, occurred (Raskin, 2011).

Ruskin influenced Otero-Pailos' thinking regarding the consideration of dirt as part of a building that should be maintained and unchanged. However this idea about preservation is in opposition to Viollet-le-Duc ideas. Viollet-le-Duc never hesitated to replace existing elements believing that preservation is "[a] means to reestablish [a building] to a finished state, which may in fact never have actually existed at any given time" (Viollet-le-Duc, 1990, p. 195). This means that he would add and remove element's and argues that it should be included to bring the building to a state of perfection (Semes, 2009).

Viollet-le-Duc's scientific methods involved research and analysis of materials, techniques and styles of the time. He used the term 'critical analysis' to refer to the process he used to his projects(Semes, 2009). Viollet-le-Duc understood that each project was created with different styles and techniques, which can vary from place to place. He insisted on researching the past, an approach that was necessary in order to understand the complete history of existing buildings (Semes, 2009). It has been used in many projects around France such as the Cathedral of Notre Dame in Paris and the small medieval city of Carcassonne. Carcassonne was a city falling into ruins, Viollet-le-Duc decided to restore it by embellishing elements, for instance, adding a new gate and towers that never existed before (Bloszies, 2012). He argued that the city lacked true style unlike the surrounding cities. The result was an exaggerated expression of the past (Bloszies, 2012).

Viollet-le-Duc believed that he needed to restore or complete the original architect's intention. This allowed him to be creative and remove parts of a building that he thought were inferior to the overall style (Semes, 2009). To restore, he would invent elements that he believed would bring the building to a 'state of perfection.' He believed what he was doing, taking creative control, was the proper approach to preservation.

Viollet-le-Duc's restoration attempts in some buildings caused controversy. Some called him "a reckless auteur bent on back-dating [buildings] to conform with his own stylistic prejudices..." (Semes, 2009, p. 119). In some cases he took total control in interpreting the original architect's intention. This brings up questions: "what is the role of the architect within preservation? Do they act like an archaeologist who 
researches and interprets or an artist who creates a new vision of the existing design?" (Semes, 2009. p. 118).

The debate between Ruskin and Viollet-le-Duc shows the two different theories on preservation. Ruskin, the 'conservationist' believed that buildings should be maintained in their found state, thereby preserving their integrity and authenticity. Viollet-le-Duc, the 'restorationist' wanted the buildings to achieve its ultimate state and took creative initiative with his interpretation. Despite their differing views on preservation, their approaches have changed the way we design existing buildings today.

\subsection{Preservation Terminology}

Since John Ruskin and Eugene Viollet-le-Duc, new theories on preservation have emerged. However, within the context of this thesis it is not necessary to go into detail regarding the evolution of preservation, and the difference between them. However it is important to note the different terminology that is used in the discourse of preservation architecture. It is also important to understand that different disciplines, countries and organizations define these terms slightly differently.

Preservation in the broadest sense is the process of protecting, maintaining and or stabilizing buildings in the found condition, whether in ruins or in fragments (Canada's Historic Places, 2010). It is important to prevent the building from further decay and to keep it safe in order to showcase its historical, cultural and heritage values.

Conservation is the process that maintains the character of the building so it can retain its value (Canada's Historic Places, 2010). It may include preservation, rehabilitation, restoration or adaptive reuse or a combination of these strategies.

Restoration is the process of returning the building to a particular period in history (Canada's Historic Places, 2010). This may involve revealing, recreating or representing elements using materials and techniques of the period.

Rehabilitation is the process of repairing the building back to its original condition in a specific period using modern materials and techniques yet still retaining the original value (Canada's Historic Places, 2010).

Adaptive reuse is the process of altering, removing or adding new 
elements to the building and its function, keeping a portion of its original value (Canada's Historic Places, 2010). Recently, adaptive reuse has been in favor for being a sustainable opinion however this usually leads to neglecting the buildings integrity, character and value (Bloszies, 2012). The existing building become an empty shell, used as an after though or incompliance with cultural and political pressures.

\subsection{Preservation in the Discourse of Architecture}

In the past twenty years, we have redefined our relationship with the past, as well as how we incorporate it into our future. Within the discourse of architecture, there is increased interest in preserving architecture in order to protect it. It is our concerns for our past that makes us more aware of our cities and the need to preserve them. However, preservation can be seen as an obstacle to the future of the city. We are constantly reshaping our city, demolishing or reusing buildings and sites. This raises concerns on what is the proper approaches to preserving and protecting a sense of place that will at the same time meet our future needs.

It is estimated that about $12 \%$ of the world's surface is currently in a state of preservation (Koolhaas, 2014; OMA, Cronocaos, 2010). Rem Koolhaas has stated, "we discovered that... a large part of the world's surface is under a particular regime of preservation and therefore they cannot be changed..." (Koolhaas, 2014, January 3). Preservation then becomes a priority with heritage or other significant sites that have been deemed valuable. Groups like UNESCO designate sites and the number of preserved sites is expected to continue to rise (Koolhaas, 2014). Everything we inhabit has the potential to be preserved. The rate of which the surface is being preserved has been escalating in scale, to include landscapes and city blocks (Koolhaas, 2014). Koolhaas declares that "we are living in an incredibly exciting and slightly absurd moment, namely that preservation is overtaking us" (Koolhaas, 2014, p. 15).

Heritage preservation traditionally demands architects to strip away the layers of time, or the palimpsest, to restore details, elements or structure to its original appearance. Nathaniel Popkins makes an observation that "by finding ways to preserve these kinds of buildings, not as museum pieces but as palimpsests themselves, will add new layers of meaning and memory to the cities experience" (Popkin, 2012). This is why Rem Koolhaas and OMA office became interested in preservation and posed the question: 'What is the role of the architect and architecture in this new reality of preservation?' at the 2010 Venice Biennale exhibition called 'Cronocaos'. 


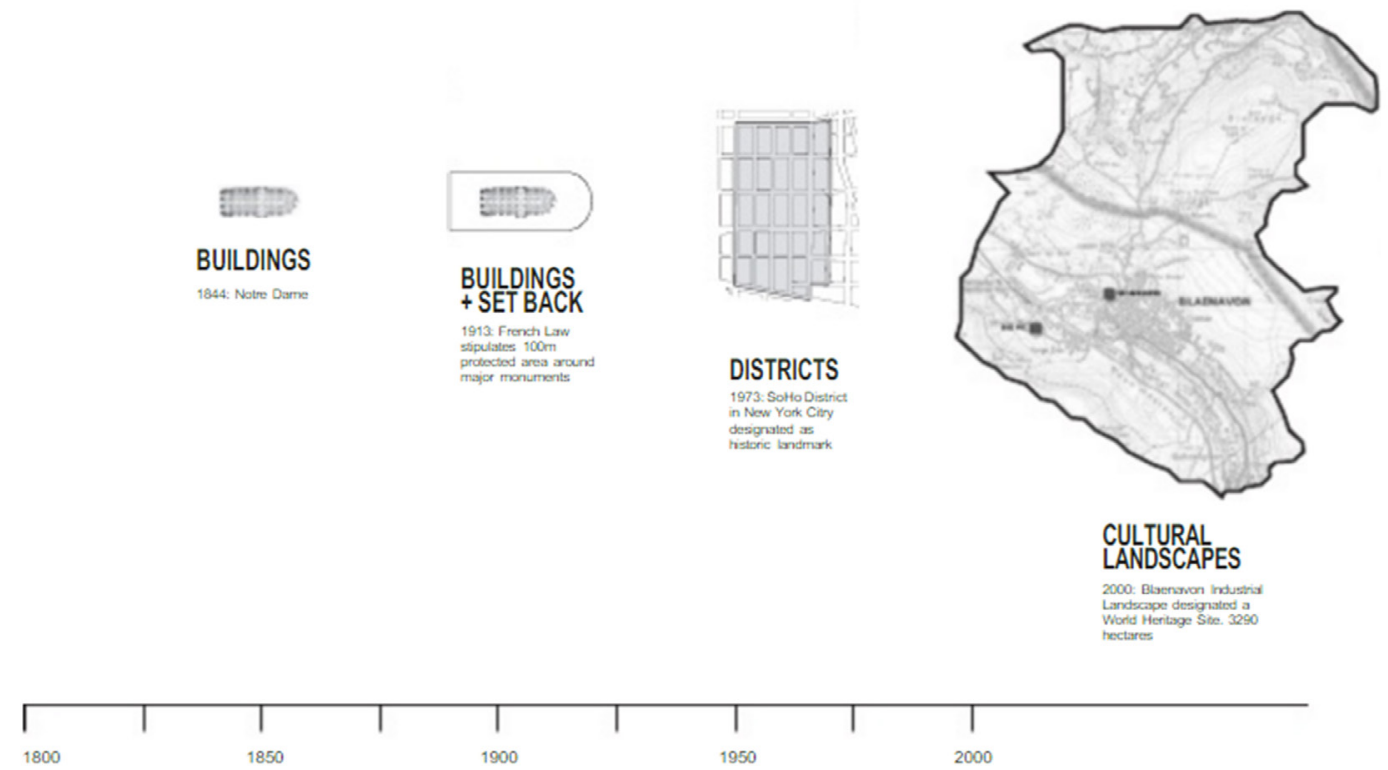

Koolaas believed that modern preservation, as we know it is an invention of the 19th century, an extension of Ruskin's and Viollet-le-Duc's theories. However, as preservation becomes a central tenet with both Fig. 7: Expansion of the scale of preservation over time from Beijing Preservation Study with Harvard, 2003 political and economic importance, the act of preservation seems to lack interest in architecture (OMA, Cronocaos, 2010). Preservation becomes an after-thought like Ruskin and Violet-le-Duc theories: modernists make preservationists look like futile, irrelevant figures (OMA, Cronocaos, 2010). Post-modernism did no better. We currently do not know how to negotiate and coexist with the changes that are occurring in preservation, or how historic buildings and contemporary buildings will fit in our future.

If we look at what is being preserved, we can see that the interval or the distance between what is being preserved changes in scale. Julian Smith, an architect and historian, outlined periods of heritage preservation and described what was being preserved. The first period or bias was between from 1700's to the 1800's and is referred to as the Antiquarian Bias; society was mainly concerned with pure preservation and with the documentation of ancient monuments, ruins and artifacts that spans over 2,000 years (Smith, 2012; Renders, 2012; Koolhaas, 2014). This was followed by the Commemorative Bias in the mid 19th century, a time when the main concern was the preservation of important sites and landscapes where important events had occurred over the past 200 years (Smith, 2012; Renders, 2012; Koolhaas, 2014). In the mid 1960's was the Aesthetic Bias; concentration was on the past 20 years and the emphasis was on about recreating, restoring and preserving sites and landscape to increase tourism economy (Smith, 2012; Renders, 2012; Koolhaas, 2014). Today we are in an Ecological Bias, where a more holistic view of understanding buildings, landscapes and artifacts should be interpreted and represented (Smith, 2012). 
Smith's observation begins with ancient ruins and monuments and moves on to religious building. This progressed to the point where even structures, department stores and factories where there is little to no association or value were being preserved. We now have a situation where we change dates when we consider whether structures are worthy of being preserved or not (Koolhaas, 2014). This is why:

"we can be the first to actually experience the moment that preservation is no longer a retroactive activity but becomes a prospective activity. This makes perfect sense because it is clear that we built so much mediocrity that it is literally threatening our lives. Therefore, we will have to decide in advance what we are going to build for posterity sooner or later" (Koolhass, 2014, p. 15-16).

Cronocaos takes the extreme position that preservation has been driven by government policies and economic forces to exploit and 'air brush' the worlds heritage for mass consumer consumption. This is a departure from the position he took in 'Generic City.' In it, he questioned a contemporary city's identity and history. He opens with:

"What are the disadvantages of identity, and conversely, what are the advantages of blankness? What if this seemingly accidental - and usually regretted - homogenization were an international process, a conscious movement away from difference toward similarity? What if we are witnessing a global liberation movement: "down with character!" what if left after identity is stripped? The Generic?"(Koolhaas and Mau, 1994, p. 1248).

Modernism has changed cities so that they have become blank, beige or generic (Koolhaas and Mau, 1994). Post-modernism has not helped matters; it has contributed to the fast pace in which generic cities develop (Koolhaas and Mau, 1994). The generic city is contained and does not grow to reflect its people's current needs. When it no longer contributes to its needs, it "just self-destructs and renews" (Koolhaas and Mau, 1994. p. 1248). The generic city becomes a production where the existing fabric of the city is seen as an obstacle to new developments.

In contrast to the principles of the generic city, we are constantly advocating for the past today as a significant source of cultural production and heritage rights. This is why Croncaos seeks to provoke current discourse. There are too many ambiguities in how preservation is defined today. The selection criteria are vague; Koolhass argues that there are many different process to approaching preservation depending on what is being preserved (OMA, Croncoas, 2010). Different objects, artefacts, buildings and landscapes have different values and meaning, depending 
on where it is and how it has affects the identity and sense of place. Time is another uncertainty, as what is being preserved should not be static (OMA, Croncaos, 2010). There is no consideration to the effects of preservation, how the "preserved could stay alive, and yet evolve" (OMA, Croncaos, 2010). Preservation continues to be selective as far as what is being preserved; it becomes distorted. The process is deeply flawed and confusing to a point that no one understands it. Preservation should not negotiate with new developments and succumb to government policies; instead, it should find a balance between innovation and preservation..

\subsection{The Role of Palimpsest in Preservation and Architecture}

Up to the present, preservation has evolved to a point where heritage societies, governments and local groups lobby for authenticity, ancientness and beauty of what is being preserved. It was during John Ruskin and Eugene Viollet-le-Duc's time that we saw modern preservation for the first time. Modern preservation has not changed since the 19th century. Our view of the concept is limited, however, as architects today try to find a balance between modern innovation and preservation of the past. I believe that one way to accomplish both is to use palimpsest as a method to reveal the complex relationships of a site. It will allow what has been preserved to be expressed, and will bring depth and meaning to the buildings, objects and landscapes.

Most historic buildings are truly irreplaceable. They conjure up nostalgic feelings that remind us of our past. Many individuals sees them as endangered places that should be preserved and protected.

The desire to save these buildings can originate from two viewpoints. First, many people are interested in preserving meaningful architectural elements such as crafted details, styles and quality of work. They fear that new buildings will be subpar to existing buildings (Bloszies, 2012). Secondly, many people have an emotional reaction to older buildings and are therefore against contemporary architecture (Bloszies, 2012). The desire to preserve comes from the desire to maintain a connection to the past. This is important because they contribute to a city's identity and sense of place. Architects therefore have advocated that historic buildings should be preserved through restoration, rehabilitation or adaptive reuse.

Restoration, rehabilitation and adaptive reuse has evolved over time. Since ancient times, existing buildings, ruins and sites have been adapted 
Fig. 8: Bath of Diocletian in Rome, converted by Michelangelo in 1534 from a Roman bath in ruins to Basilica of Santa Maria Angeli

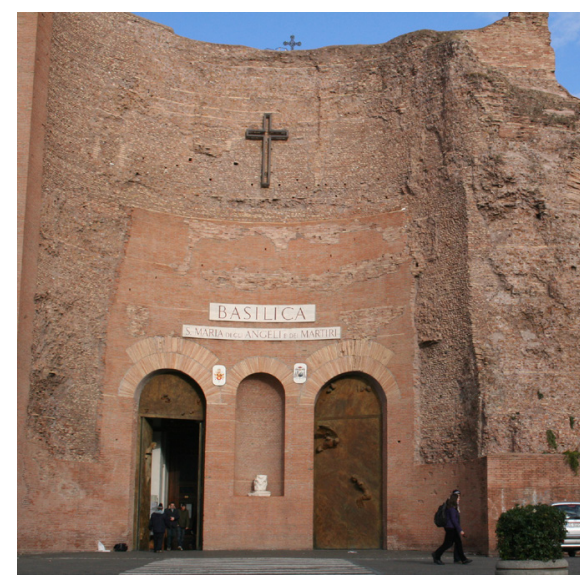

into new designs to establish a new dialogue with the ideas of its time. For example, Michelangelo, in 1534, converted a Roman bath called 'The Bath of Diocletian' in Rome into a basilica (Brooker and Stone, 2004). Another great example is the Great Mosque - Cathedral of Cordoba in Spain. The site was originally built as a Christian church around 500AD, but was replaced by a Muslim mosque in 800AD (Bloszies, 2012). In plan, the mosque was rectangular, with arcades of highly decorated and brightly colored arches. In the 13th century, the site once more became a Christian church (Bloszies, 2012). By 1525 Hernan Ruiz designed a cathedral with Gothic nave at the center of the mosque (Bloszies, 2012; Oterio-Pailos, 2014). His crude intervention clashed with the existing style and made some believe that it ruined the mosque. However, it also helped preserve the site at the moment it was most vulnerable (OterioPailos, 2014). Important buildings were expected to be constantly adapted; according to Graeme Brooker and Sally Stone, "they evolve and they changed, but their reuse emphasizes continuity" (Brooker and Stone, 2004, p. 9). This continuity involves the reuse of the building, it structure and spaces where meaning and memory is imbedded within the place. They become mnemonic devices to promote certain ideologies or values of its time. This creates a complex palimpsest, where different meaning and value are layered on top of each other and where new buildings cannot reproduce this quality today.

There are many different approaches to bringing new life to an existing building that go beyond restoring it to its original appearance; these may neglect the strata of time or convert or re-use a building for the sake of preservation. The success of revealing the old and the new layers depends on an understanding that the existing building will provide the principles and basis for appropriate interventions. This is evident in Castelvecchio in Venice by Carlo Scarpa, and Neues Museum in Berlin by David Chipperfield. The questions of material, form, method and detail come up regarding to what degree they will be used, and how appropriate they are for the exiting building.

According to Robert Klanten and Françoise Astorg Bollack there are different strategies and methods of using existing buildings that demonstrate the possibilities of architectural intervention that explores palimpsest as a design method.

The add-on approach is where future interventions build upon existing buildings, structures, ruins or traces of remains, where the palimpsest that exist (Bollock, 2013; Klanten and Feiresiss, 2009). This can involve additions that enlarge the existing building's space, or change how the initial building works all together. The addition relies on the exiting elements such as structures and circulation (Bollock, 2013). The addition 


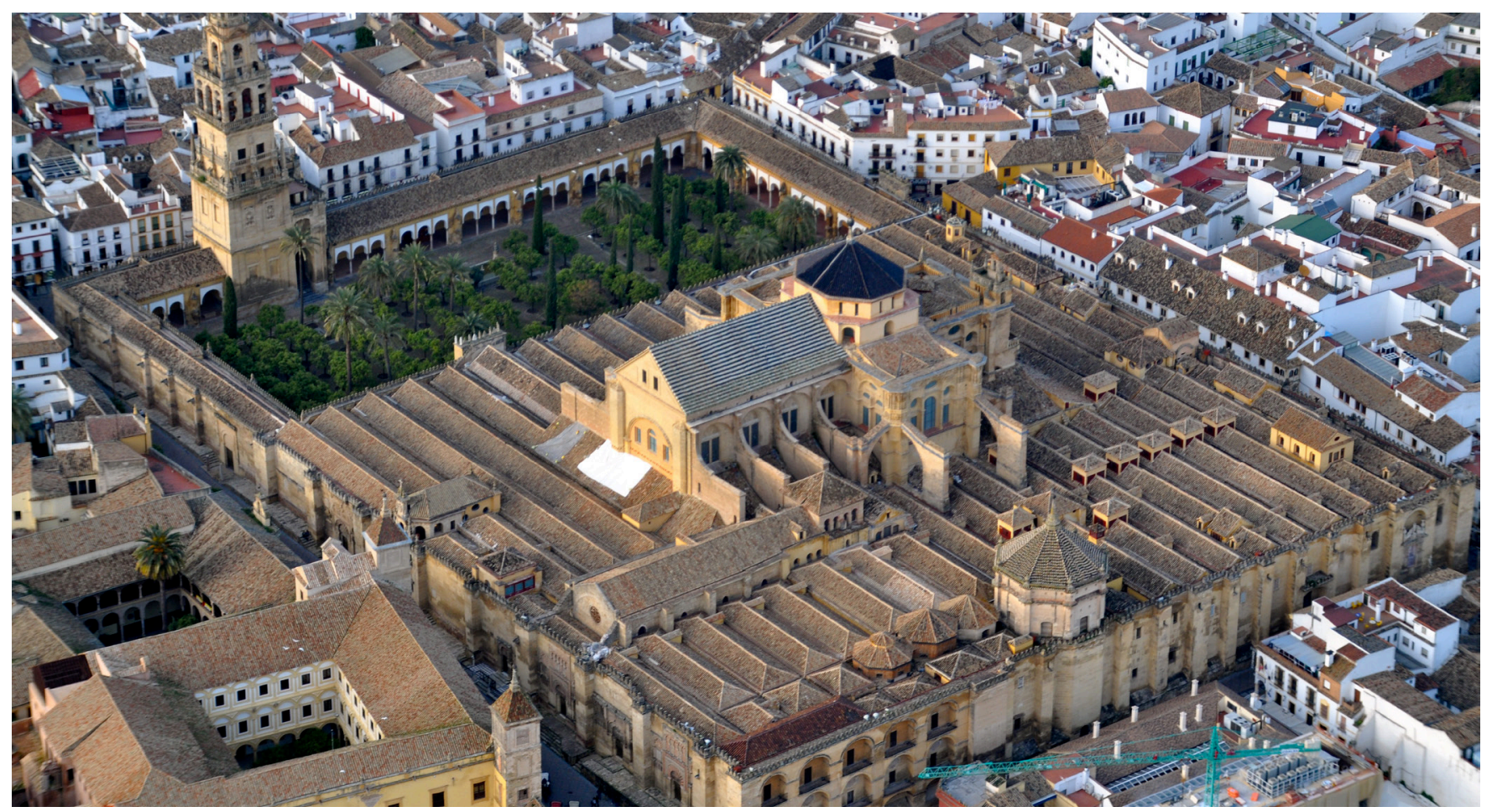

can interact with the existing elements and impose itself directly on the traces. New spaces are introduced with the new additions, demonstrating how future additions works with palimpsest in unexpected ways.

The wrapped approach seeks to preserve the palimpsest, whether it is found in whole building, ruins, artifacts or fragments, by providing a protective layer (Bollock, 2013). The intervention can be a series of surfaces, elements or a simple shelter that surrounds the palimpsest. It allows the designer to create spaces that introduce an interactive experience into the historical layer without the distraction of the new intervention.

The weave approach involves weaving the new intervention in and out the existing buildings (Bollock, 2003). The intervention between the new and old is not easily recognizable. The architect can alter, restore or erase existing elements. Replacing them for new interventions. The internal organization can be changed, allowing for new interpretation of the traces that remains.

The insertion approach involves new elements being layered onto existing buildings, structures or sites (Bollock, 2003; Brooker and Stone, 2013). These new elements can reveal, hide or highlight different intentions. Insertion seeks to contrast with the existing building, to highlight history and to make the structure the center of its space. This intervention can alter and change a building, adding new sections or elements even as it carefully erases others to create a dialogue between the old and new.
Fig. 9: The Great Mosque - Cathedral of Cordoba, converted from a church to a mosque and a cathedral over the centuries 


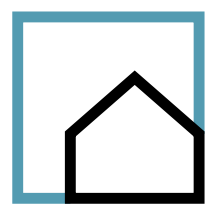

Fig. 10: Add-on Approach is where future interventions build upon existing buildings, structures, ruins or traces of remains, where the palimpsest that exist. The following architectural objects (left \& right) shows an exploration of add-on approach.

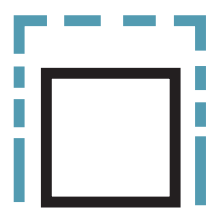

Fig. 11: Wrap Approach seeks to preserve the palimpsest, whether it is found in whole building, ruins artifacts or fragments, by providing a protective layer. The following architectural objects (left \& right) shows an exploration of wrap approach.
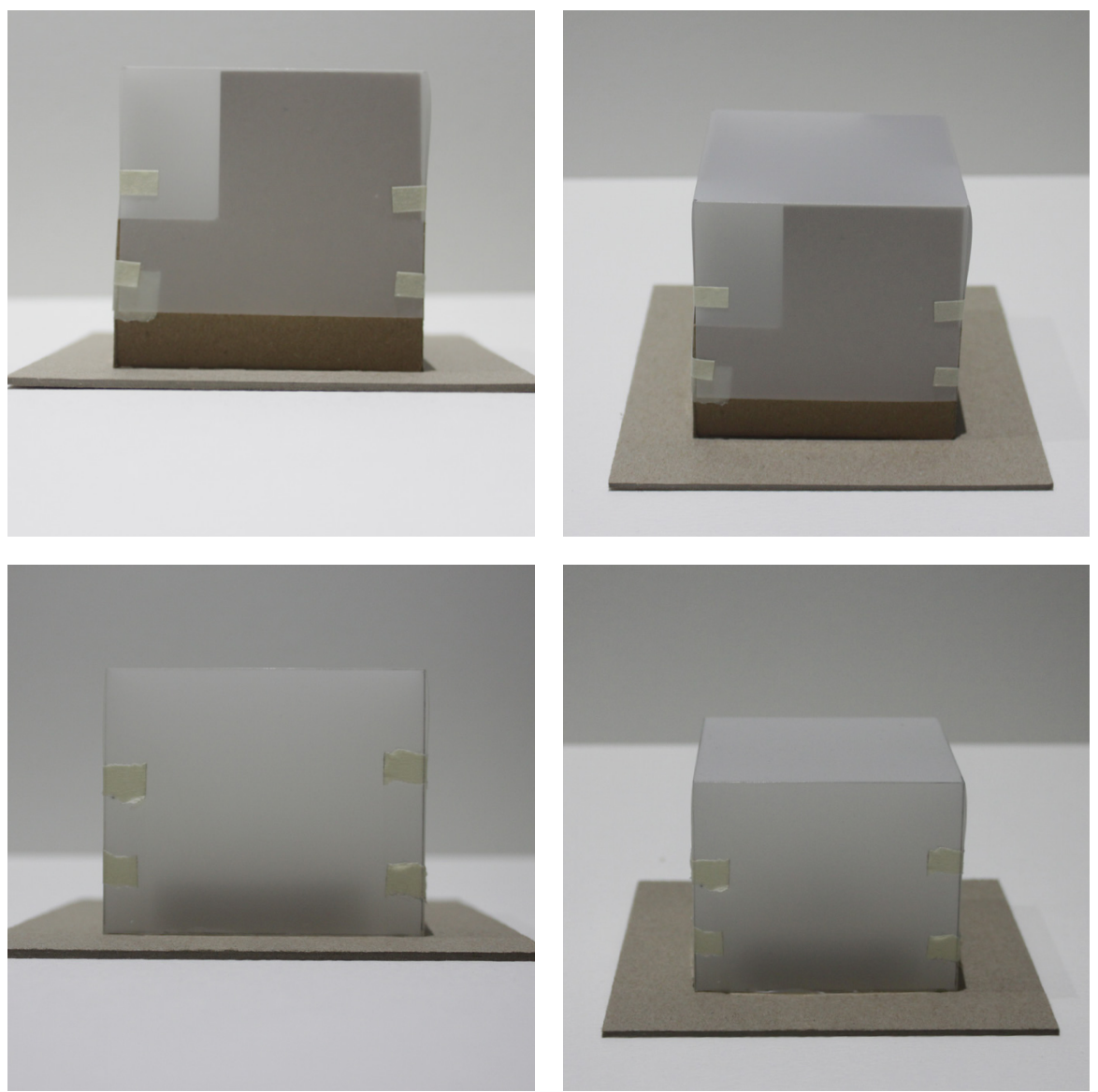


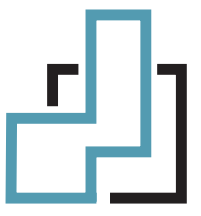

Fig. 12: Weaving Approach involves weaving the new intervention in and out the existing buildings. The following architectural objects (left \& right) shows an exploration of weaving approach,

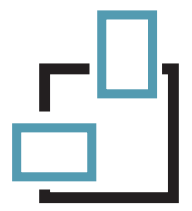

Fig. 13: Insertion Approach involves new elements being layered onto existing buildings, structures or sites. The following architectural objects (left \& right) shows an exploration of insertion approach.
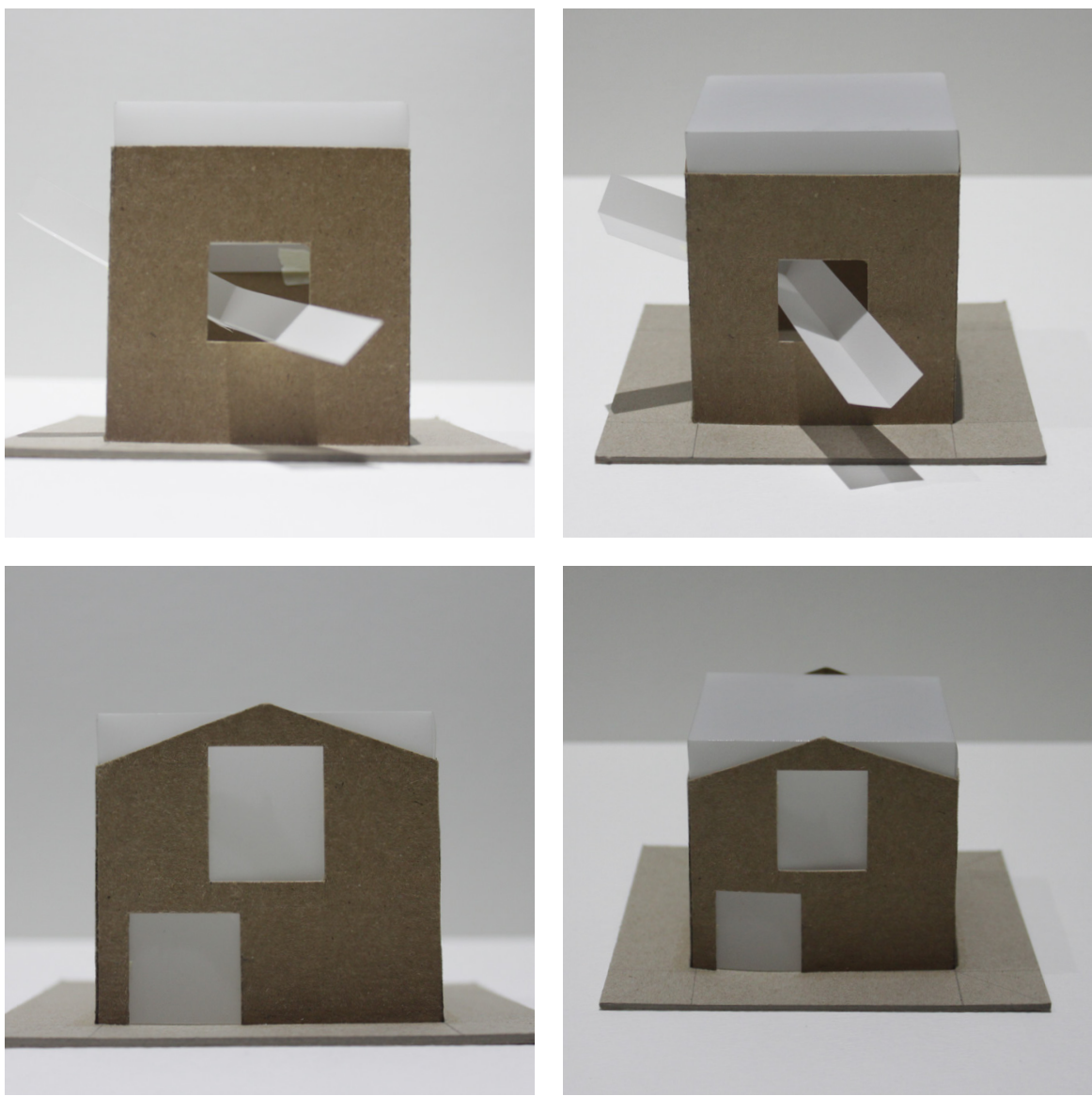

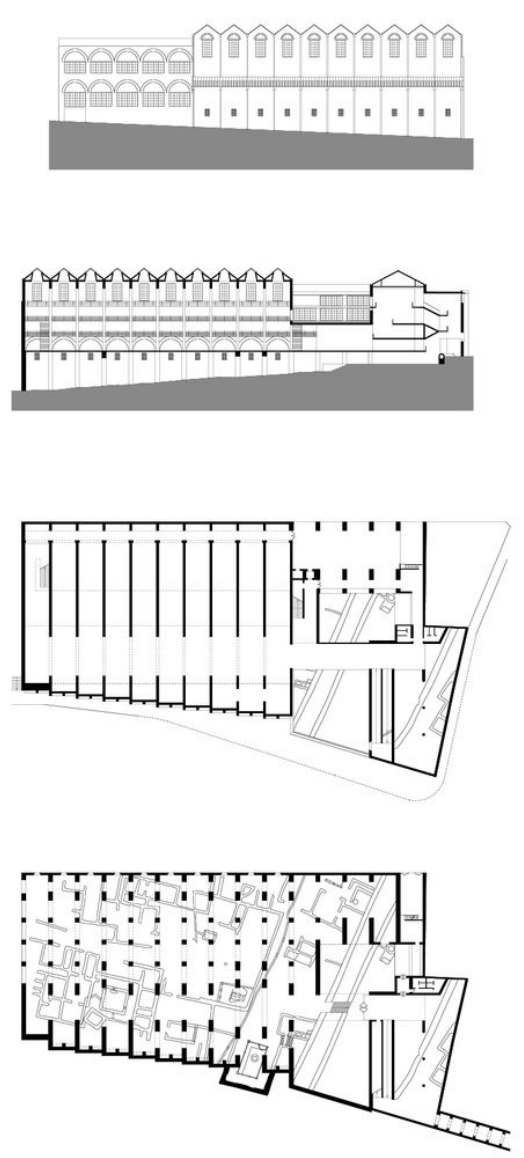

Fig. 14: (left) Section, plans and elevation of the National Museum of Roman Art in Merida Fig. 15: (right) A sculptural fragment of an emperor at the end of the gallery. The brick veneer and arched door way recalls the influence of Roman construction techniques

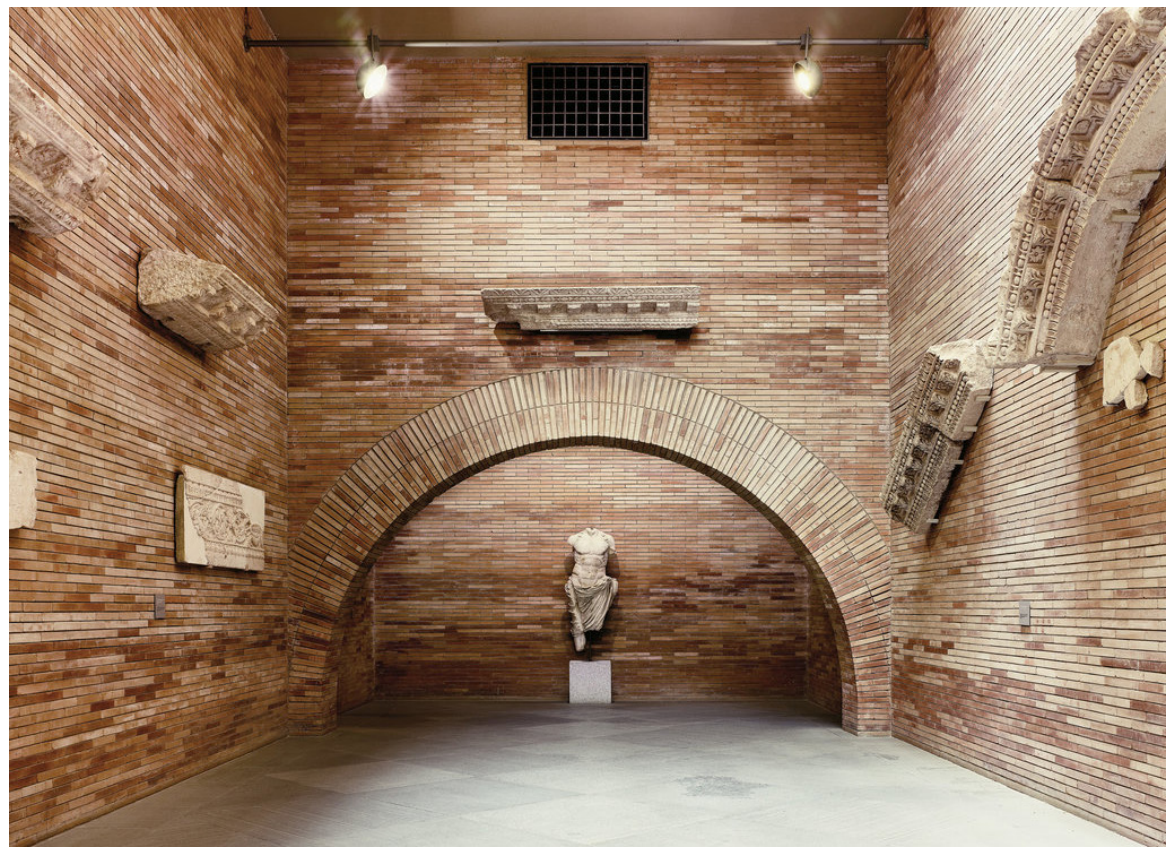

\subsubsection{Case Study: National Museum of Roman Art Rafael Moneo | Merida, Spain | 1980-86}

'Tradition' is an important aspect of Rafael Moneo's work. It is especially evident in the National Museum of Roman Art at Merida, Spain, where he layers ideas of memory even as he uses traditional Roman construction techniques. Moneo has been able to reveal the complex relationships in the Roman Museum history and its collective memory by interoperating the palimpsest that exisit on the site.

The Roman Museum at Merida was built in $1980-86$ upon an existing archaeological site where ruins of Roman buildings were found (Brooker and Stone, 2004). In 25BC, Emperor Augustus founded Merida as a capital of a colony. Large Roman monuments were built, which lay beneath the foundation of the existing city (Brooker and Stone, 2004).

The design was built over ruins like many buildings in Merida. The lower level of the museum exposed the ruins, leaving them in its found condition as an archaeological investigation. The rest of the museum was added on; careful negotiating ruins with tall spacious galleries displaying Roman artifacts

Moneo's design was influenced by the city's ancient pasts. Traditions and especially Roman construction techniques became important to the design. A series of parallel concrete walls made of arches covered in Roman bricks runs through the building and touches the surface of the excavation site. 


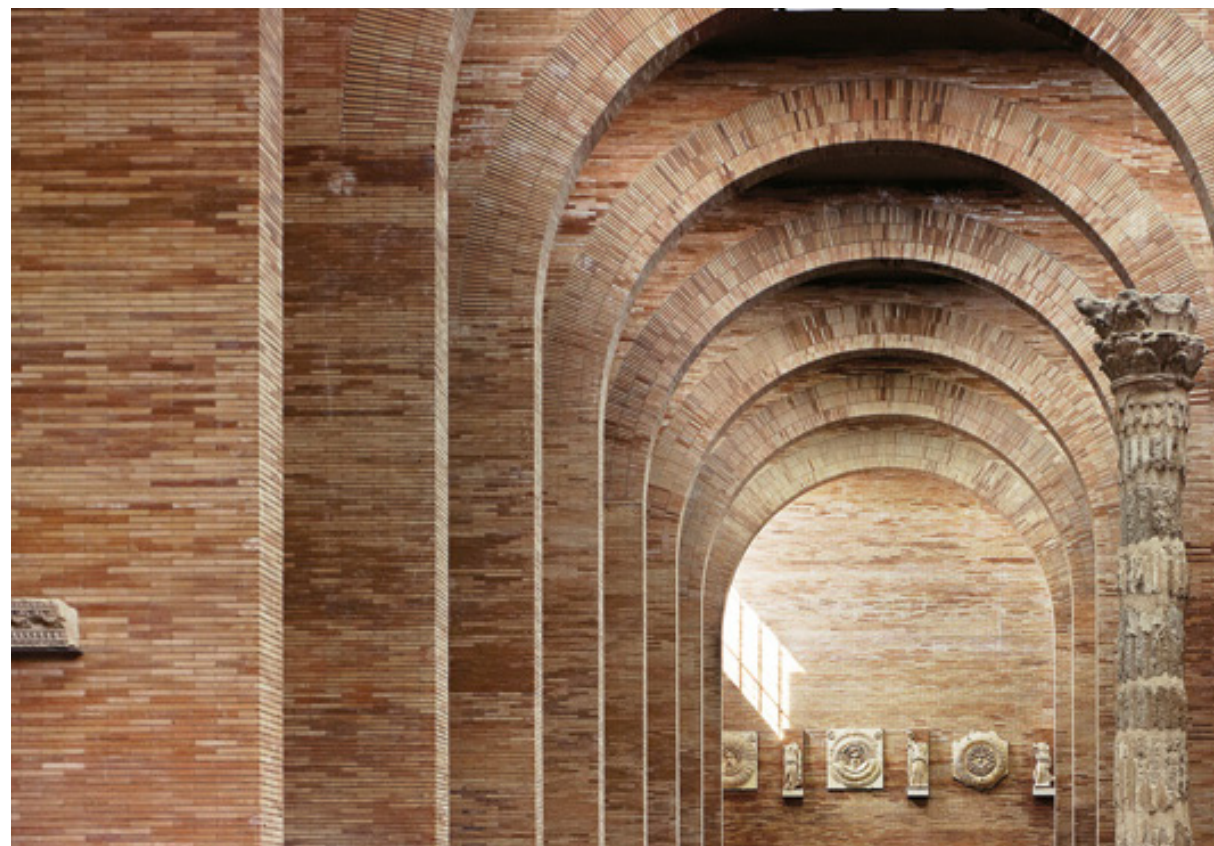

The arcade made of arches was inspired by the Roman aqueducts that once supplied water to the city. The arches, a quintessential element of Roman architecture, reflect the importance of Roman design in Merida. The main exhibition space is created by tall arches parallel to each other that recalls the nave of ancient Roman Basilicas (Ornelas, 1995). Moneo drew inspiration from public buildings such as public forums and baths.

The use of bricks also inspired Moneo; however, instead of constructing the museum out of bricks, Moneo used them as a vaneer to finish off the concrete arches. This technique was similar to that of late Roman construction, where bricks were placed over concrete structures (Brooker and Stone, 2004). The structures merge modern materials with traditional techniques, thereby revealing the relationship of the past and present.

At the lower level, the space is constructed into a large exibition hall with parallel concrete arch walls that showcased the ruins. Larger arch were occasionally used to highlight a particular artifact or ruin (Brooker and Stone, 2004). The grid of the structure does not run parallel to the Roman ruins; instead, it intersects and allows visitors to focus on the ruins instead of the distracting of Moneo's design.

The design of the Museum is respectful and does not overpower the ruins; nor does it compete with them (Ornelas, 1995). By reinterpreting the past, Moneo was able to reveal the palimpsest at various levels: from the construction, to the organization, from the materials to the details. Moneo created a modern building with a Roman presence. The museum represents a transition between the old Roman past and Mireda's future without recreating the past. The Roman Museum reveals the collective memory and identity of the site and city.

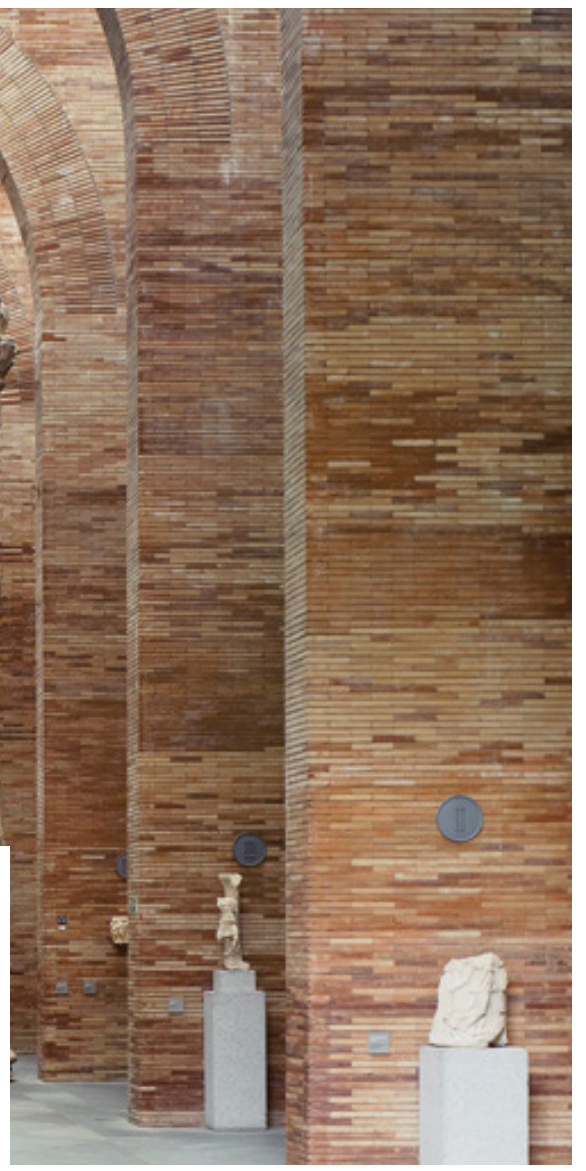

Fig. 16: Main gallery of the National Museum of Roman Art 


\subsubsection{Case Study: Shelter for Roman Archaeology Peter Zumthor | Chur, Switzerland | 1985-86}

The Shelter for Roman Archaeology combines Peter Zumthor's fascination with materials and tectonics to enhance the experience of a space. Built over ruins of an archaeological site, the design shelters four Roman quarters. In 15BC the Roman Empire settled in Chur, making it one of the oldest Roman Settlement in Switzerland (Martin, 2013). Zumthor wrapped the archaeological site with a protective cover that acts as a museum and also a visitor center.

The design enclosed each of the four Roman quarters, following the outer perimeter walls. By following the perimeter, Zumthor revealed the size and scale of the original building through an abstract recreation of the Roman Quarter. A window is placed along the street which represents that main entrance to the Roman Quarters. This allows visitors the opportunity to imagine the daily life of a Roman citizen that once lived within the settlement.

The building is made out of a wood frame structure with wooden shades that enclose the archaeological site. The wood shades allow penetrate into the space while large skylights allows admit natural light (Martin, 2013). While the main entrance is discreetly tucked away to the side.

Zumthor's design focused on how visitors are able to observe and interact with existing ruins. A suspended walkway was designed to allow visitors to observe from above but also allows visitors to step down onto the historical layer of the archaeological ruins.

The ruins become a layer of meaning and memory of place, a palimpsest that reveals itself to visitors as they descend into the space.

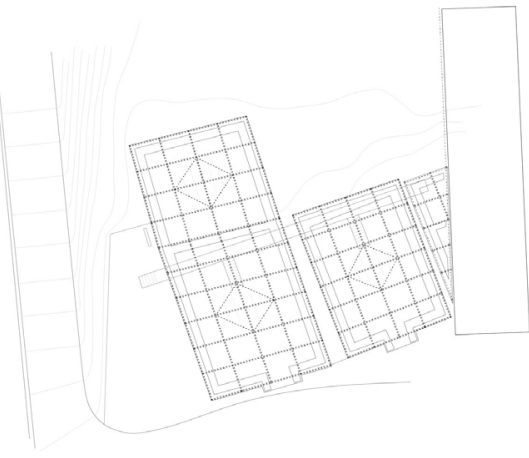

Fig. 17: Plan of the Shelter for Roman Archaeology The fact that they are at the same level of the original Roman floor allows visitors to interact with the ruins without being distracted by Zumthor's design.

Zumthor allows the palimpsest of the site to reveal itself to the visitor as they walk through the space. By observing from above, a larger picture of the archaeological site is revealed. Zumthor carefully crafted a narrative of the ruins through the use of craft details, materials and circulation and the abstract recreation of the Roman Quarters allowing visitors to interpret the space. 

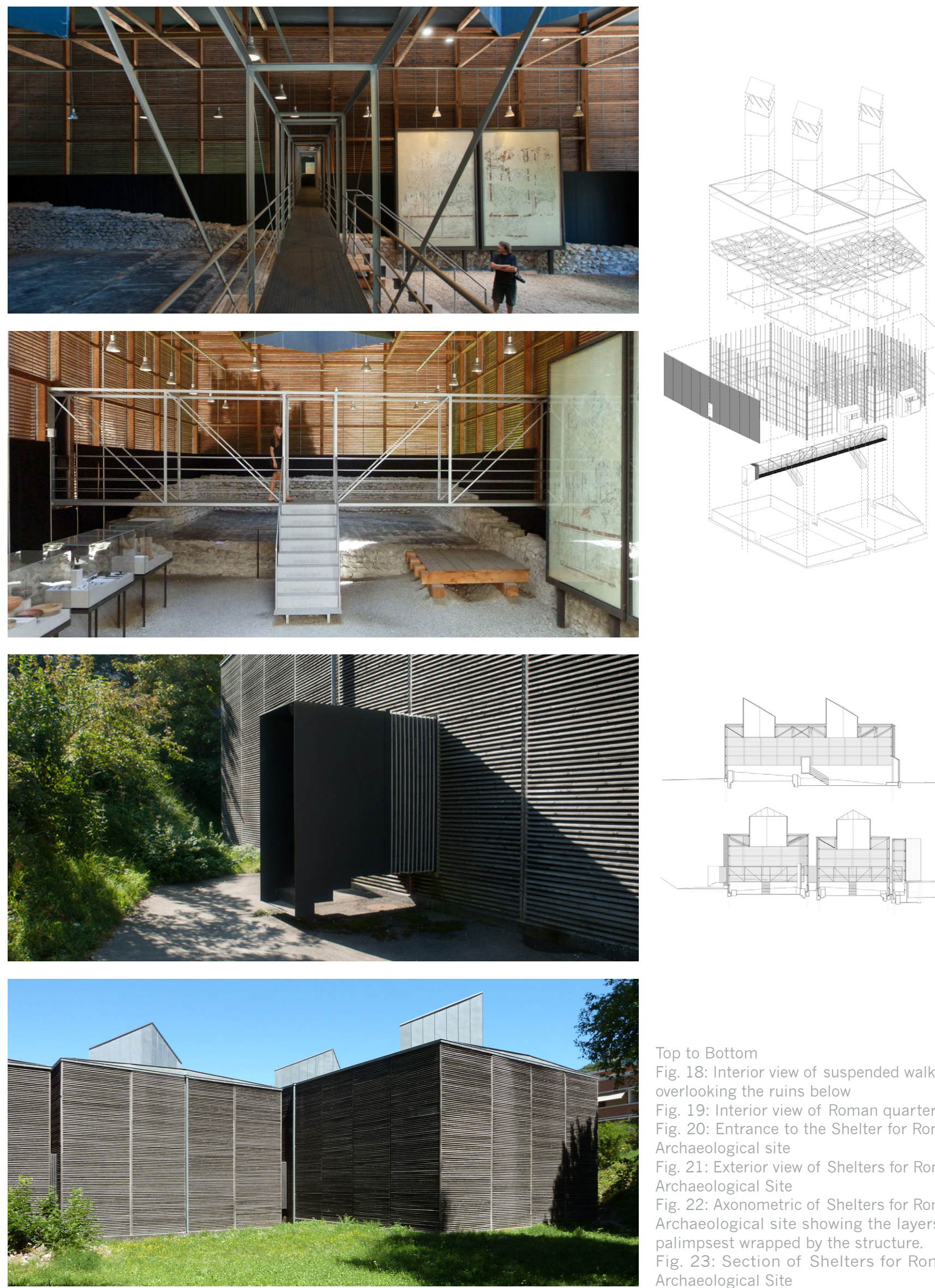

Top to Bottom

Fig. 18: Interior view of suspended walkway overlooking the ruins below

Fig. 19: Interior view of Roman quarters Fig. 20: Entrance to the Shelter for Roman Archaeological site

Fig. 21: Exterior view of Shelters for Roman Archaeological Site

Fig. 22: Axonometric of Shelters for Roman Archaeological site showing the layers of palimpsest wrapped by the structure.

Fig. 23: Section of Shelters for Romar Archaeological Site 


\subsubsection{Case Study: Hamar Bispegard Museum Sverre Fehn | Hamar, Norway | 1969 -1973}

Sverre Fehn's Hamar Bispegard Museum in Hamar, Norway was designed to reveal multiple layers of new and existing figures through the weaving method. It is a path through time where the visitors travel through layers of palimpsest, intersecting all the layers of time in a single journey. The building reveals itself through a process of interpretating the site, of the existing building and ruins, and of details of time. Fehn explains:

"Time and place must follow one another. Time in itself is a material" (Shields, 2014, p. 238).

In the 18th century, a barn was built upon the ruins of the Bishop's Palace. The palace and barn intersects and weave into each other, layering elements that were built up over time. The result is a complex palimpsest that Fehn weaves within and on top of the existing condition (Shields, 2014).

The existing barn was designed in a u-shape, creating a central courtyard. Fehn inserts a elevated concrete ramp to guide visitors though the palimpsest. The ramp intersect multiple layers of time from the present, to the 18th century barn, and the medieval ruins of the palace. The ramp weaves though the building to create a narrative of history of the site ending at the ruins which is exposed in its archaeological state. The concrete ramp becomes a device that allows visitors to move between different layers of the palimpsest.

Materiality and details are also important to the design. Wood was used to recreate the barn roof, while glass panels were used in section of the walls. Instead of filling the exposed section, Fehn decided to

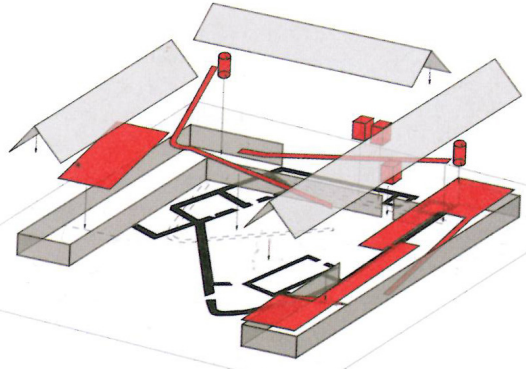

Fig. 24: Axonometric diagram showing the new museum inserted over the ruins of the old fortress and barn leave them as they were to allow visitors from within to understand the natural decaying process of the building. Fehn inserted these elements to contrast with the ruins and existing buildings.

Bispergard Museum represents a palimpsest where visitors are able to travel through the different layers. The design reveals the site, building and ruins to allow a dialogue between the past and present. It also preserves and interprets the layers, allowing the past to reveal itself. At the end, Svere Fehn explains: "If you chase after the past, you will never catch up to it. Only by manifesting the present can make the past speak" (Fehn, 1992, p. 17). 


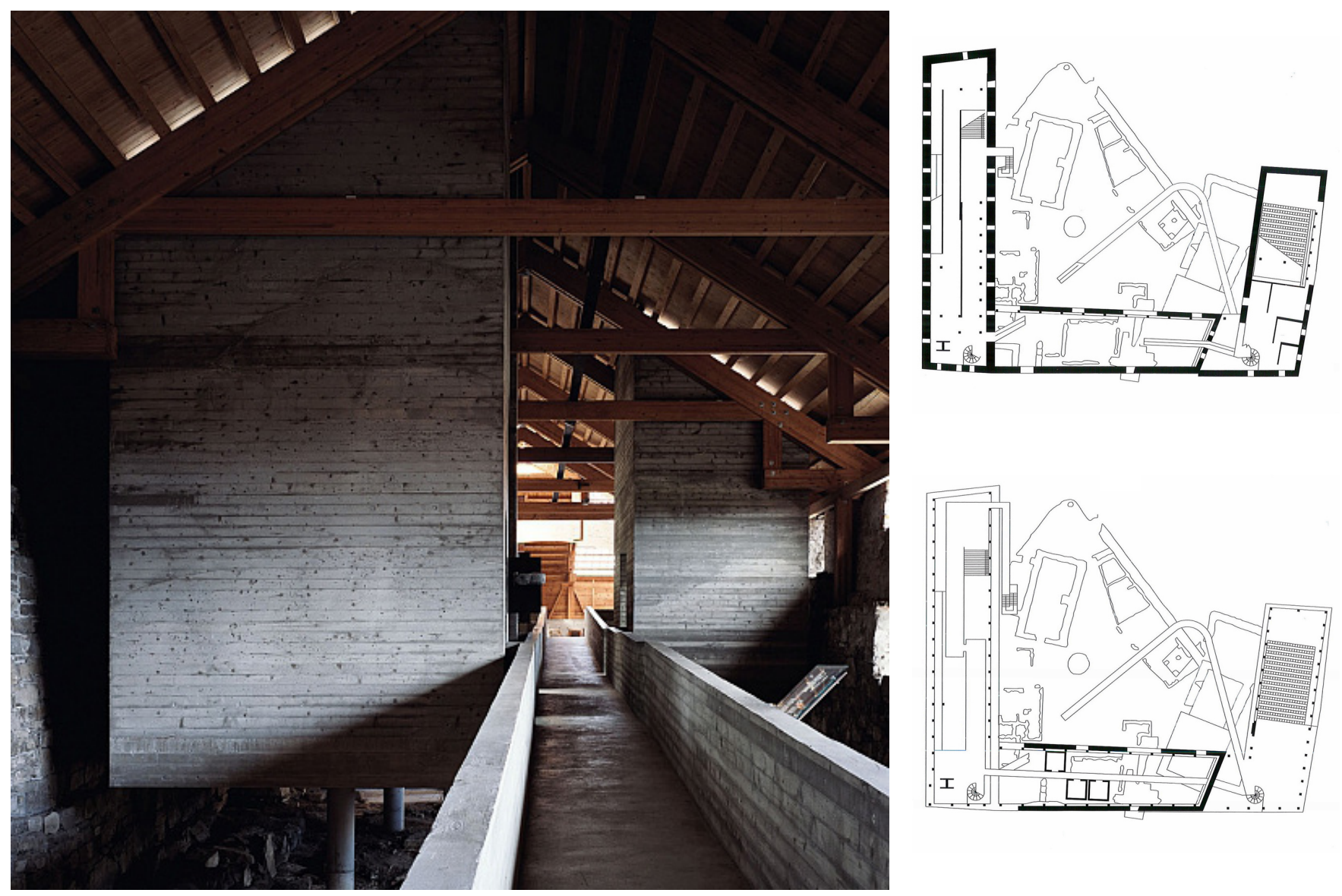

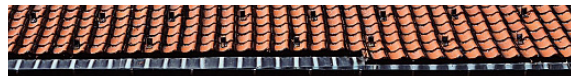

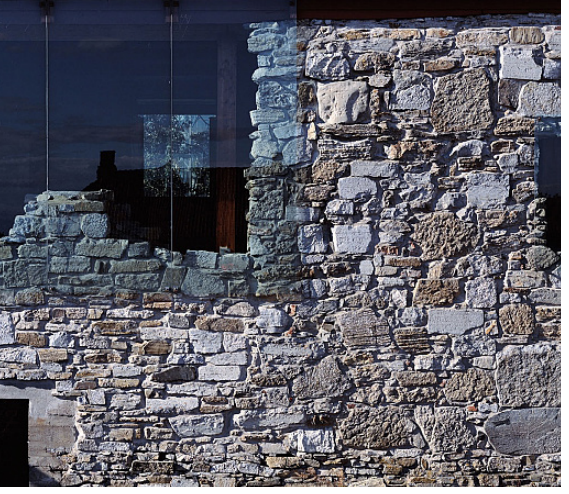

Top to Bottom

Fig. 25: Interior view of the concrete ramp through the west wing

Fig. 26: Plans of the Hamar Bispegard Museum

Fig. 27: Exterior view of the detail of the old wall openings with glazing

Figure 28 Exterior view from the ramp across the fortress court

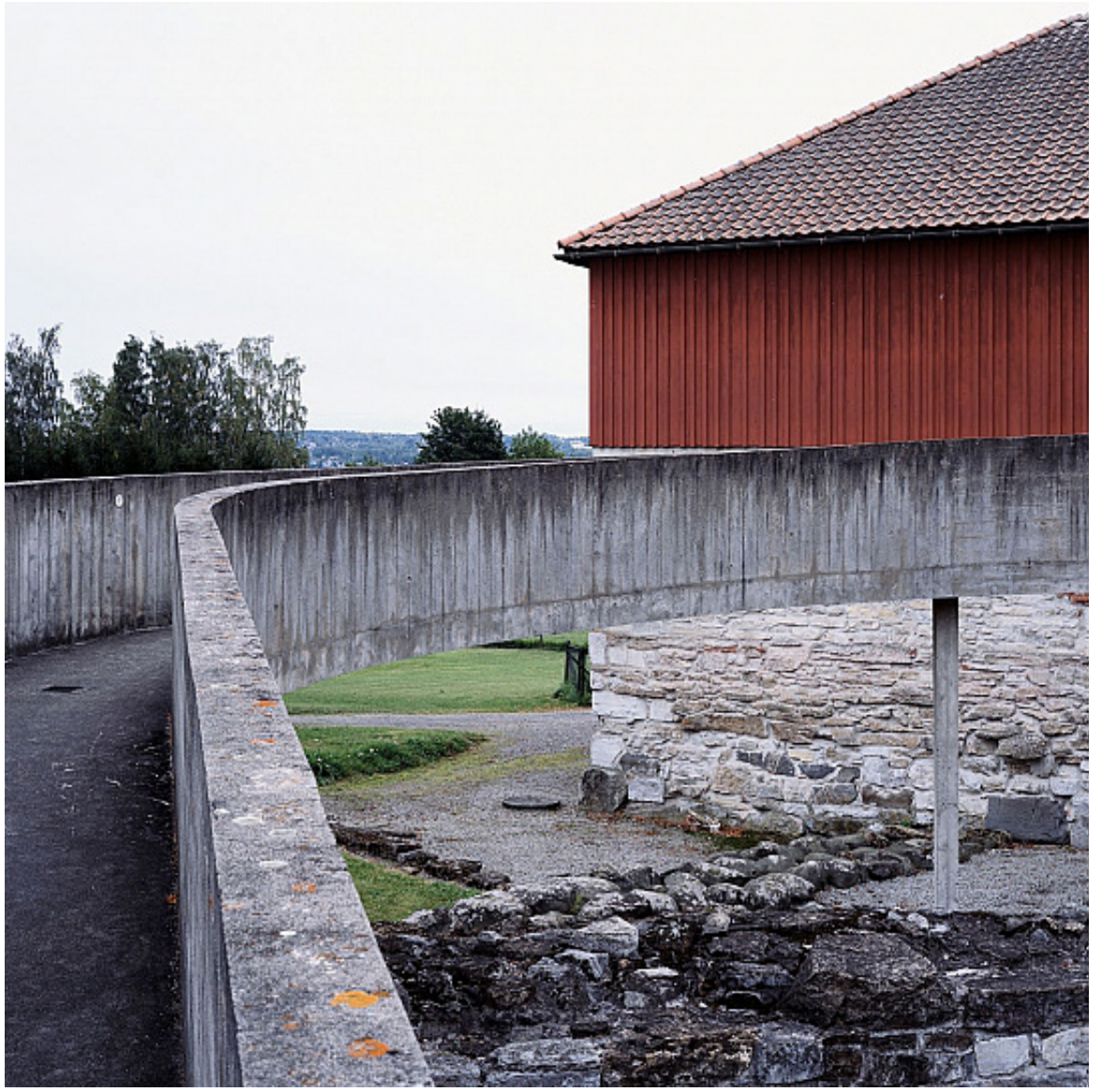




\subsubsection{Case Study: Neues Museum \\ David Chipperfield | Berlin, Germany | 1997-2009}
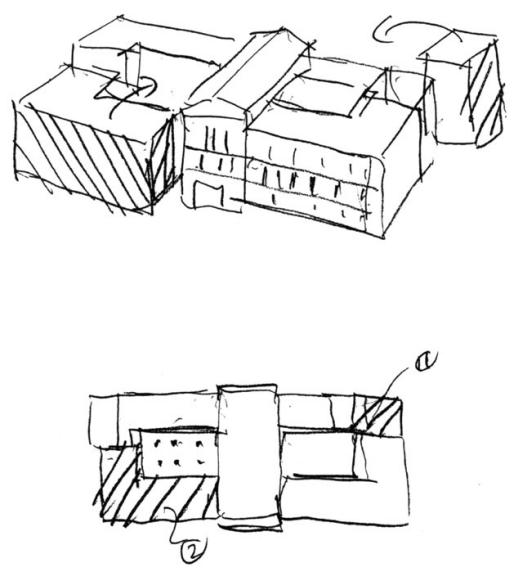

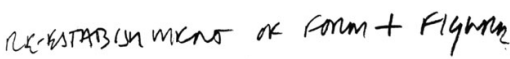

Fig. 29: Sketch of re-establishment or the tracing of the form and figures
Opposite

Fig 30: (top) Exterior view of the Neues Museum

Fig. 31: (middle) The process of revealing the layers that remain in the Medieval Room (left) restoration drawing of the Medieval Room floor, (centre) restoration of the room, (right) final interior view

Fig. 32: (bottom) The view of the main staircase, (left) 1900 view of the interior, (center) 1945 view of the interior after the bombing of berlin, (right) 2009 reinterpretation of main staircase.
The Neues Museum was built by Fredrick August Staler for King Kredrick Wilhem II of Prussia, as a place for 'Art and Science' (Bollack, 2013). It was initially designed as a three story neoclassic building with two interior courtyards and a monumental stair. The museum showcased works from different ancient civilizations. Staler's intial design incorporated many artifacts into the museum such as Greek, Roman and Egyptian columns, plaster reliefs and frieze.

During WWII, the building was damaged: it lost one courtyard and the main staircase was destroyed. David Chipperfield was tasked to reinterpret the building. He explains:

"Our vision was not to make a memorial to destruction, nor to create a historical reproduction, but to protect and make sense of the extraordinary ruin and remains that survived not only the destruction of the war but also the physical erosions of the last sixty years. This concern led us to recreate a new building from the remains of the old, a new building that neither celebrates nor hides its history but includes it. A new building was made of fragments or parts of the old but once again conspiring to a completeness" (Bolack, 2013, p. 214).

The new reconstruction of the building is subtle, yet can be easily identified. Materiality becomes important to the design. Instead of recreating the museum, Chipperfield created an abstract version of the original using new materials referencing the scale and proportion of the existing building. David Chipperfield's interpretation layers the new and old, an attempt to preserve the sprit of the place. His new addition such as the main staircase was modest, using new materials. It traces the original volume of the staircase without literally recreating it.

The design takes into consideration the palimpsest that exists. Staler created a palimpsest by using Greek, Roman and Egyptian elements within the original design. Staler did not use them just as decorative pieces but also as structural elements, creating a new palimpsest with traces of the past. This meant that Chipperfield also was working with the palimpsest. Interior elements were revealed in patchwork, for example the design peels away part of the building's surface to reveal the layers of its construction. He inserts new materials discreetly creating a contrast that works with the palimpsest. 

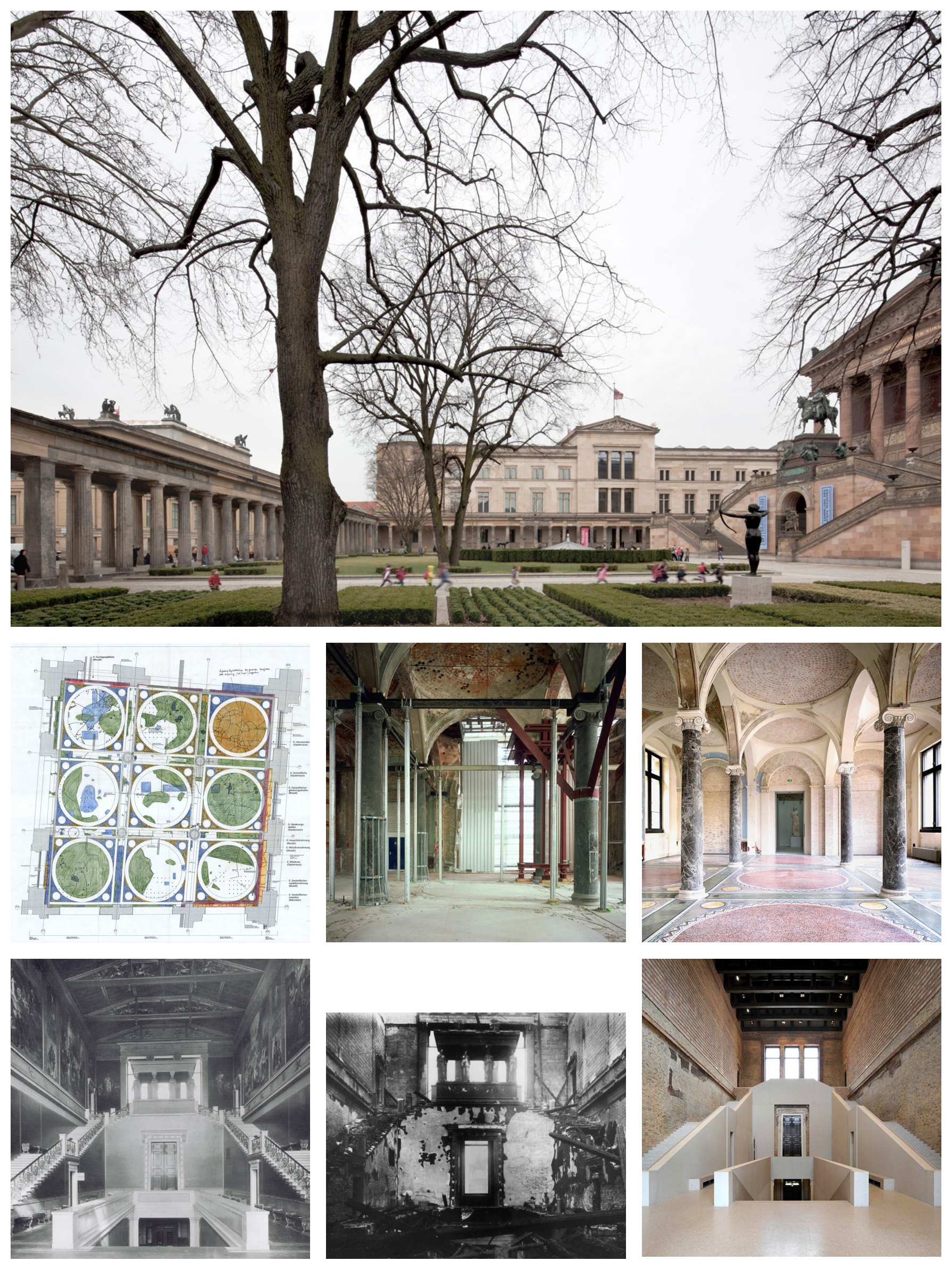
The Neues museum was able to embody the collective memory of all layers of activity. The original building was used and appeared alongside new elements. The passage of time and events like war are visible through a series of insertion and reveals. The juxtaposition of the old and new highlights the layers of activity. The discrete use of new materials and the interoperation of the past is able to highlight the way layers of activity in the museum exisit without distracting the narrative of the past.

For a successful architecture projects to succeed there must a substantial understanding of the past, or palimpsest, that remains. The design can be influenced by traces even as it creates a balance between the old and new. As seen in the case studies, each method can reveal the palimpsest and preserve what remains. Current methods of preservation such as conservation, rehabilitation and adaptive reuse fail to take into consideration the multiple layers of history. Using palimpsest as a metaphor in architecture can aid in the revealing and preserving of meaning in existing buildings.

The next section comprises a design project for this thesis; it will focus on applying these theories and research to an existing palimpsest in the context of Toronto. 


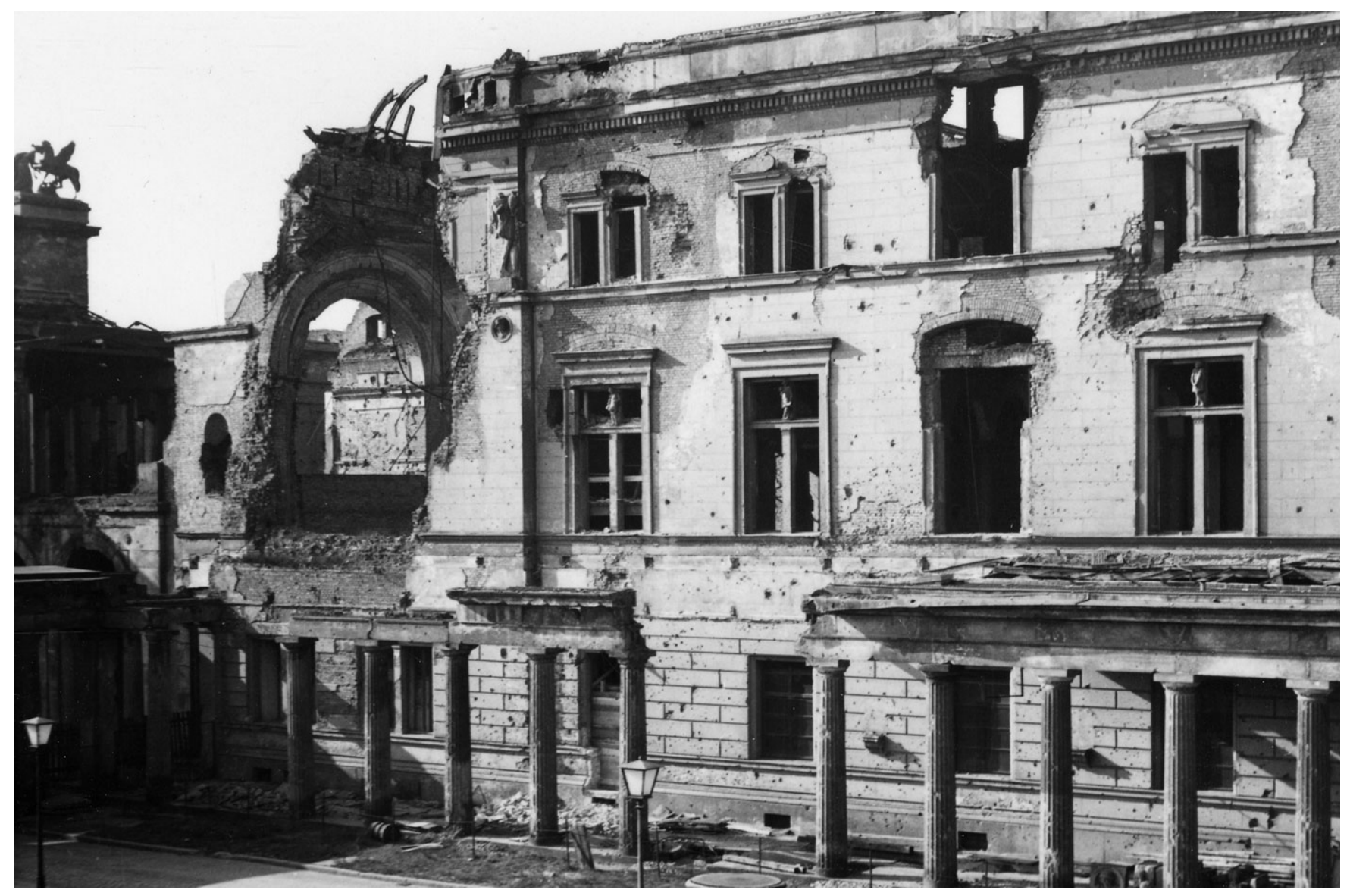

Fig. 33: Neues Museum, 1945, the scars of war can be seen through the decaying state of the museum 
Section 3.0

Design Proposal 


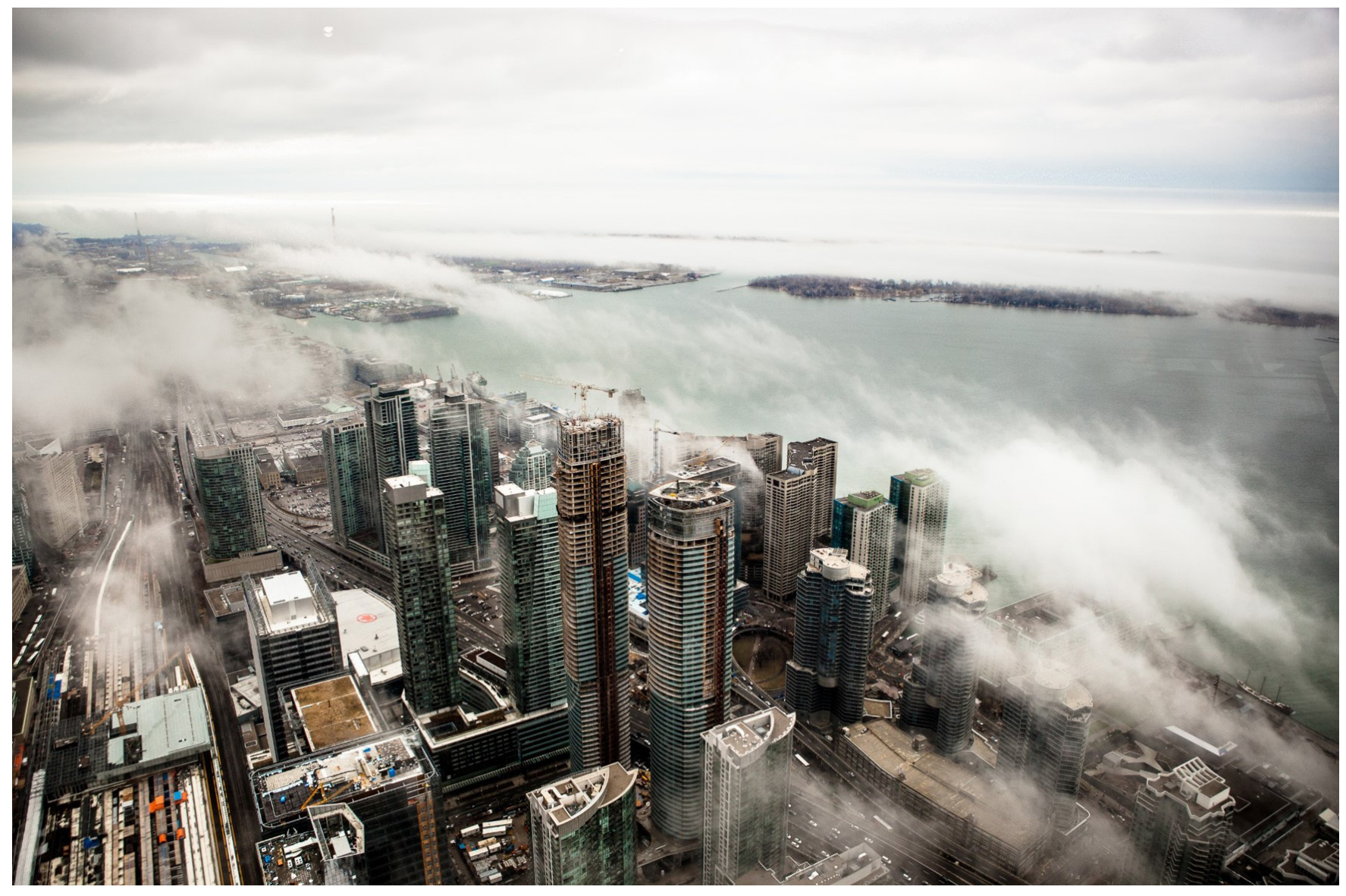

Fig 1: Aerial view of Downtown Toronto 


\subsection{Introduction}

The City of Toronto is currently going through a massive construction and development phase, transforming the city's neighborhoods and landscape. Buildings are constantly being built and demolished and built all over again leaving traces behind. The demolition of existing buildings within Toronto has made us more aware, and has given us a greater appreciation, of the city's rich architecture, cultural, archaeological and natural heritage. The current policies of preservation, conservation and adaptive reuse in Toronto have been slow to act in promoting the reasonable and appropriate use of existing building. The policies and procedures are lengthy which allows buildings to fall to neglect and demolition. I believe that there are ways to address theses issues of preservation that go beyond adapting existing and new policies.

Preservation, at times, requires that we strip away the layers of palimpsest in order to preserve a building back to a particular time, neglecting the layers of time that exist (Popkin, 2012). The city is a palimpsest, with layers on top of each other. It would not be possible for the cities today to be a palimpsest without the act of preservation of buildings (Popkin, 2012). It is possible to use traces that remain, the palimpsest, to help us inform new designs, bring a sense of depth and meaning to architecture.

The first two sections, have provided some background on the history and evolution of palimpsest and preservation in architecture. This section will focus on my design exploration with the research provided for the ruins at Stanley Barracks, proposing a design that incorporates the palimpsest to reveal the narrative that exists. 


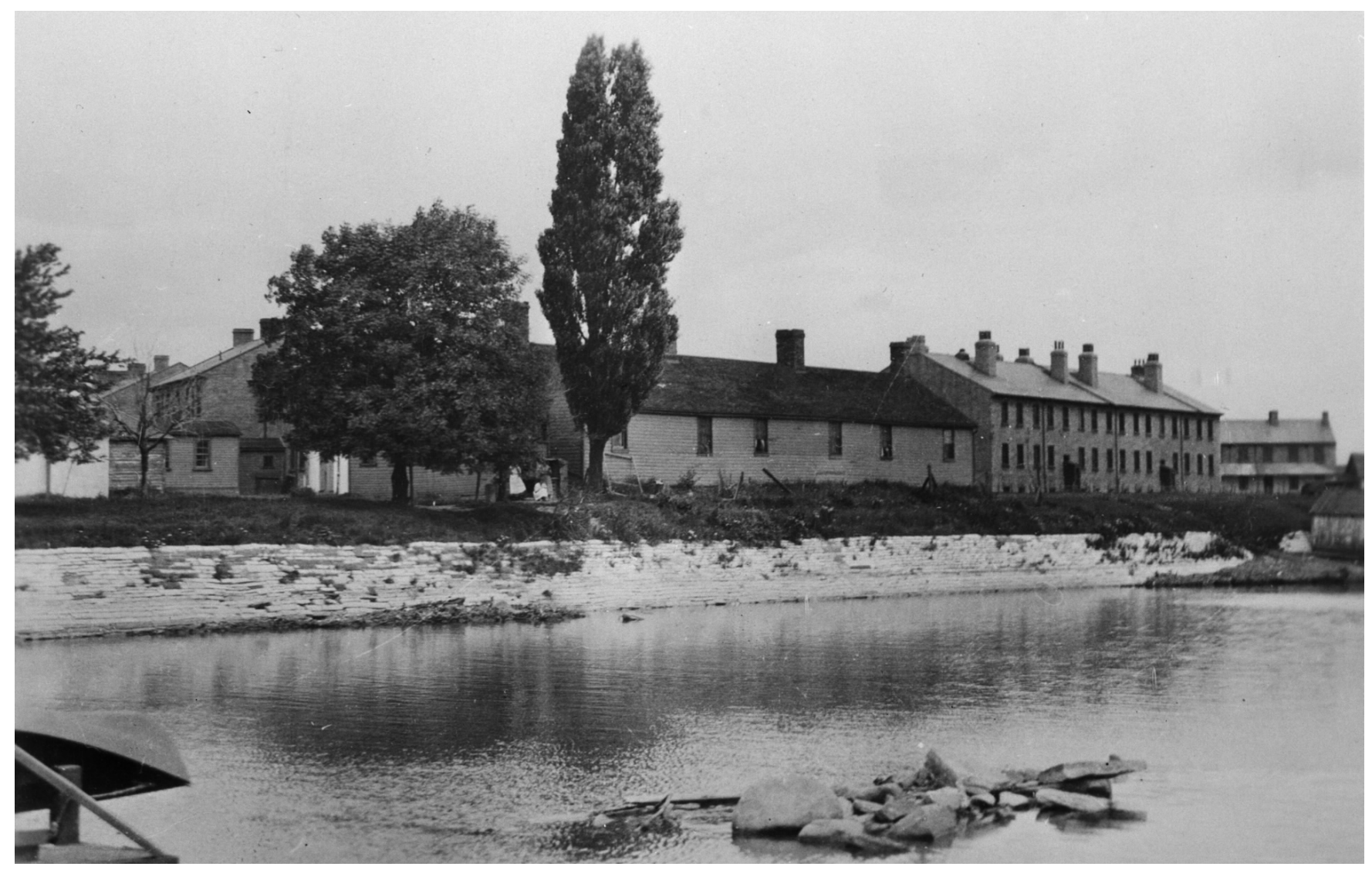

Fig. 2: View of Stanley Barracks from the lakeshore 1930
Stanley Barracks was chosen for a few reasons, first its current state of neglect. Stanley Barracks has been transformed into its current state due to political and economic reasons. This allows the history of the site to be suppressed but not forgotten. Second, as a new development is being proposed near Stanley Barracks, questions arise as to how the new intervention addresses the history of the site, the identity and sense of place. And third, as part of the archaeological investigation, ruins of foundation walls and trenches were discovered. Assuming buried below the layers of rubble and modern infill lays intact ruins of the demolished barrack buildings. With this assumption, this thesis proposes to reveal the layers of traces that remain.

\subsection{The History of Stanley Barracks Historic Analysis}

On November 18th, 1998, Toronto City Council designated the Officers' Quarters at Stanley Barracks under Part IV of the Ontario Heritage Act; recognizing its historical and military importance to Toronto. It was also recognized as an important 19th century military architecture. As one of the last buildings standing from the New Fort, the Officers' Quarter 


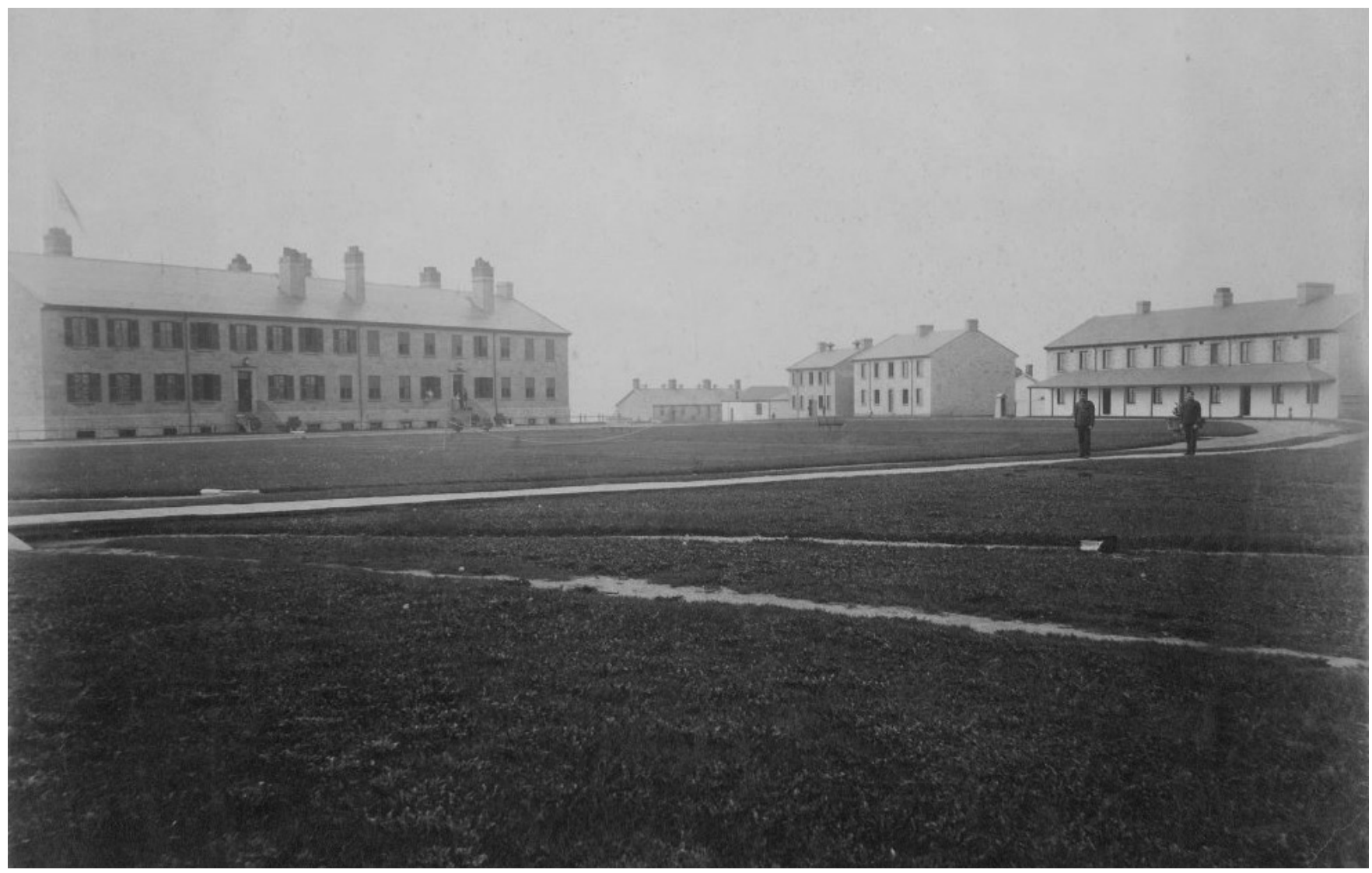

at Stanley Barracks is an important building part of Toronto's military past (City of Toronto, 2 Strachan Avenue, 2014).

Fig. 3: View of Stanley Barracks from the Parade Square looking at the Officers Barrack.

Toronto was once a military town; proudly highlighting it's dedication and commitment to the British Empire. In 1788, British authorities, along with French fur traders and Canadian Natives recognized the area as a significant site (Sendzikas, 2011). That same year, British authorities purchased the site from the Mississauga Natives where surveyor Alexander Aitkin laid out the town and identified where the garrison would be placed (Sendzikas, 2011). Lieutenant Governor John Graves Simcoe named the town 'York' after the Duke of York (Sendzikas, 2011). According to the original survey, Alexander Aitkin set aside approximately four hundred hectares of the purchased land as a military reserve: that is roughly from modern-day Peter Street to Dufferin Street, and Queen Street to the historic lakeshore.

Fort York was built in 1793 at the mouth of Garrison Creek near modern day Bathurst Street for its strategic location to defend the town from land and water. In 1812, the United States declared war on Britain, making the town of York a target. On April 27th 1813, United States navel ship with ground troops attacked Fort York, burning it to the ground and occupying the fort (Sendzikas, 2011). Following the War of 1812, the garrison was rebuilt, however, British authorities recognized that there was a need to replace Fort York. 


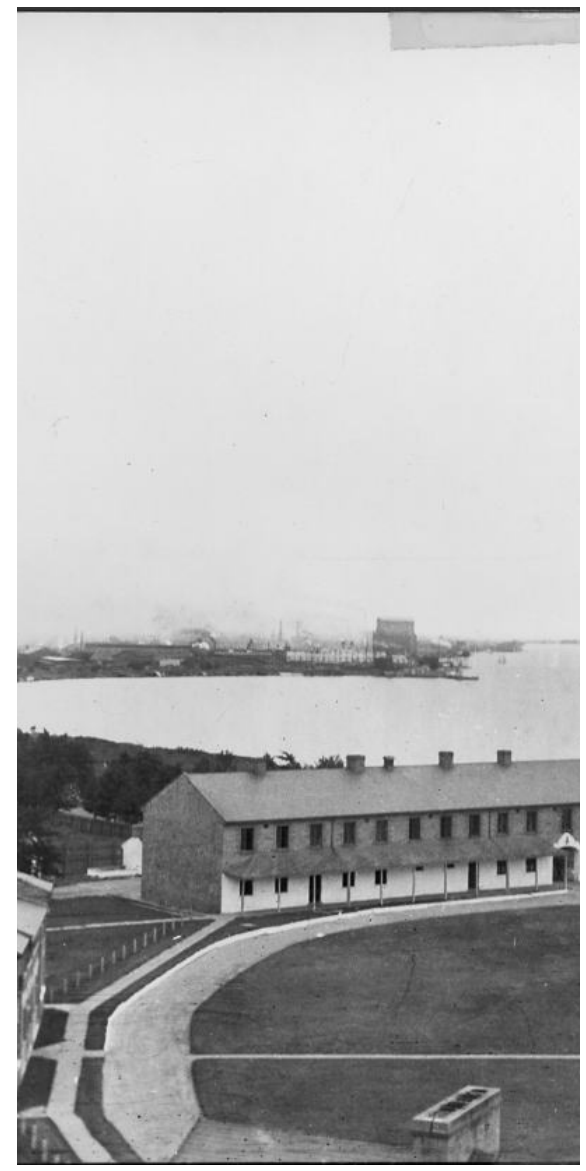

Fig 4: (right) Aerial view of Stanley Barracks with the City of Toronto in the background Fig. 5: (left) Troop drill at Stanley Barracks, 1918

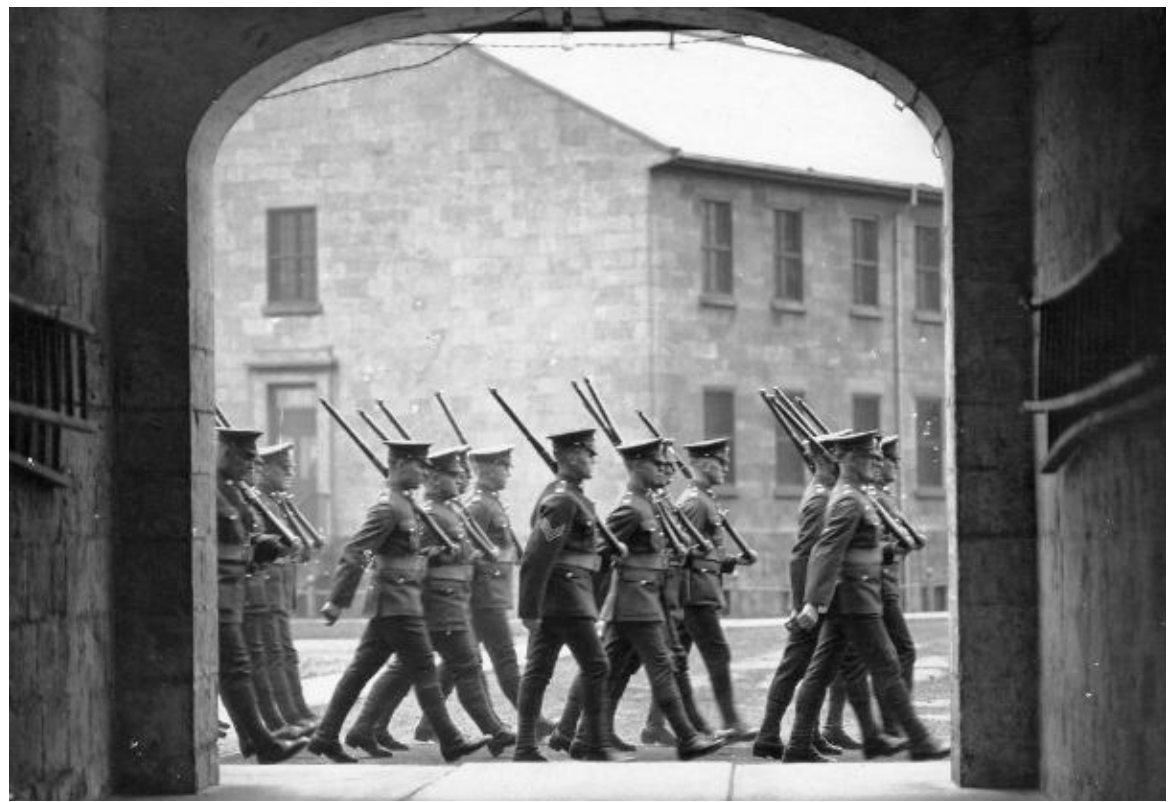

By the end of the war in 1815, the conditions at the Fort York deteriorated. In 1833, plans for a 'New Fort' to be built were underway, however due to the lack of funds it was delayed. In 1837, the Rebellion of Upper Canada occurred, along with unrest in the North West Territories prompted Lieutenant Governor Sir John Calborne to go ahead with the construction of the new fort. The new fort was proposed to be located approximately 1 kilometer west of Fort York (Sendzikas, 2011). To raise the necessary funds, the Lieutenant Governor sold the eastern section of the military reserve west of the Fort York to the Town. This allowed the town to expand west. The Town of York was renamed in 1834 to Toronto, and by 1840; the construction of the New Fort began (Sendzikas, 2011).

Simply known as the New Fort, it was constructed out of limestone, brick and wood in the Georgian Style. The plans of the new fort was designed in a polygonal fort design, with an officers' barracks, two privates' barracks, a hospital, an officers' stable, barrack master's store, an engine house, a gunpowder magazine and a canteen which was around a parade square.

The officers' barrack, that still stands today, is a two-story thick masonry building that accommodated 15 officers and captains. It is located on the south side of the parade square by the lakeshore (Sendzikas, 2011). On the north side of the parade square, opposite the officers' barrack, was the hospital that accommodated 24 beds with a full surgery wing and a nursing station (Sendzikas, 2011). The larger of the two, privates' barracks no. 1 was designed to accommodate 207 soldiers. It is located on the east side of the parade square. It acted as the main gates towards the town, with an archway at the center with two guardrooms. The smaller privates' barracks no. 2, was located on the 


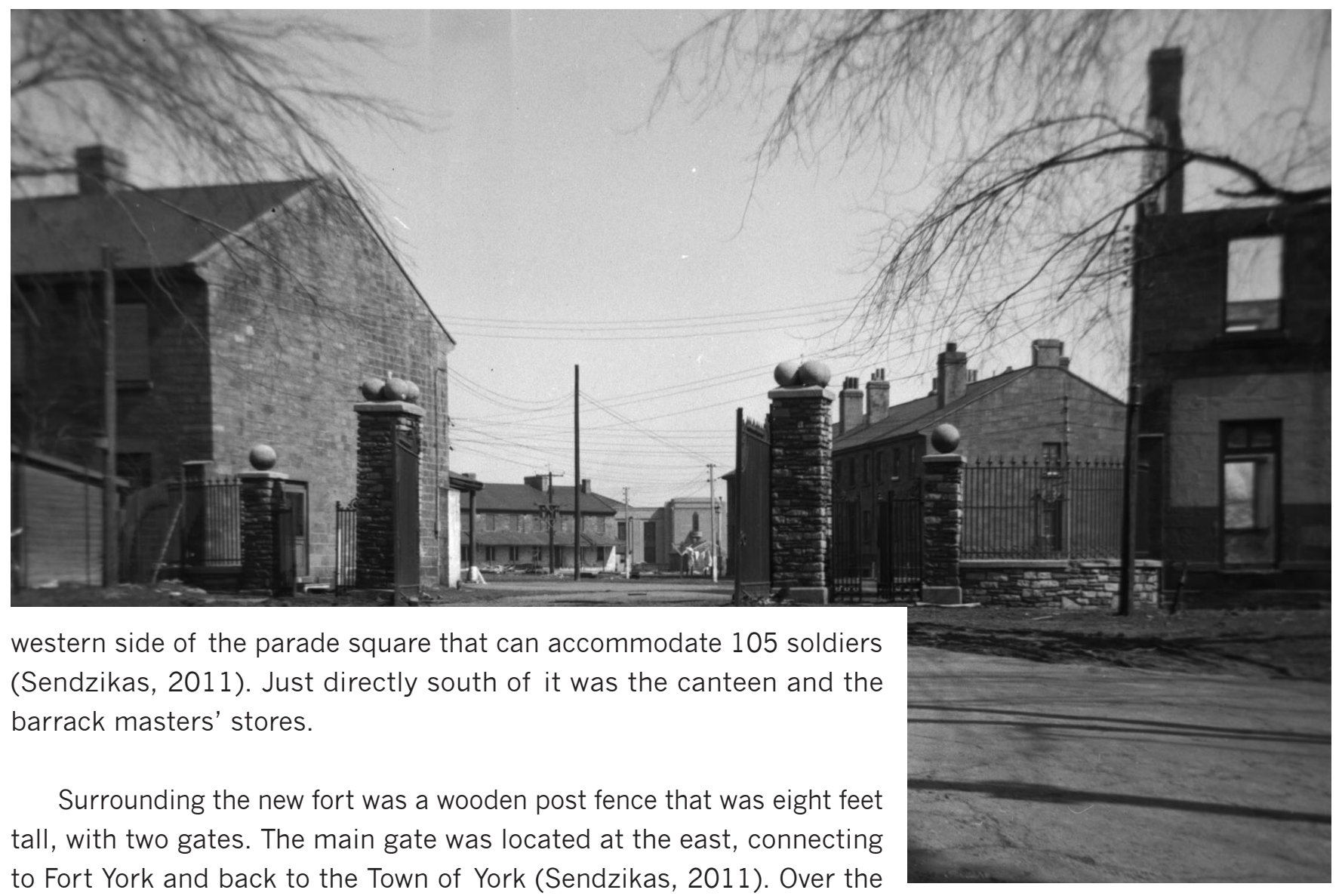
years, the New Fort made additions and alterations that were necessary as the need arose. One particular interesting addition was under the Fig. 6: View of Stanley Barracks Entrance, 1951 recommendation of the Lieutenant-General, where five tennis courts and cricket fields were created to help with troops morale as they faced cold winters (Sendzikas, 2011).

British troops occupied the New Fort initially, however, by 1870 , British troops returned to Britain as concerns in Europe grew. Many taxpayers in Britain no longer wanted to support the defense of Canada, a confederate Dominion of Britain (Sendzikas, 2011). It was believed that Canada should play a greater role in defending itself. At the end of June, the last British troops left the New Fort and by September the land was transferred to the Dominion Government and the City (Sendzikas, 2011).

Fort York and the New Fort have fallen into disrepair over the years, as there were no occupants at the Barracks. In 1873, Sir John A. Macdonald, Prime Minister of Canada established the North West Mounted Police (NWMP) the precursor to the Royal Canadian Mounted Police, stationed at the New Fort to be trained and sent to the North West Territories. (Sendzikas, 2011). By 1883, once the NWMP left, the School of Infantry was created, a new annex was built to accommodate more troops. In 1893, the Royal Canadian Dragoons occupied the fort (Sendzikas, 2011). 


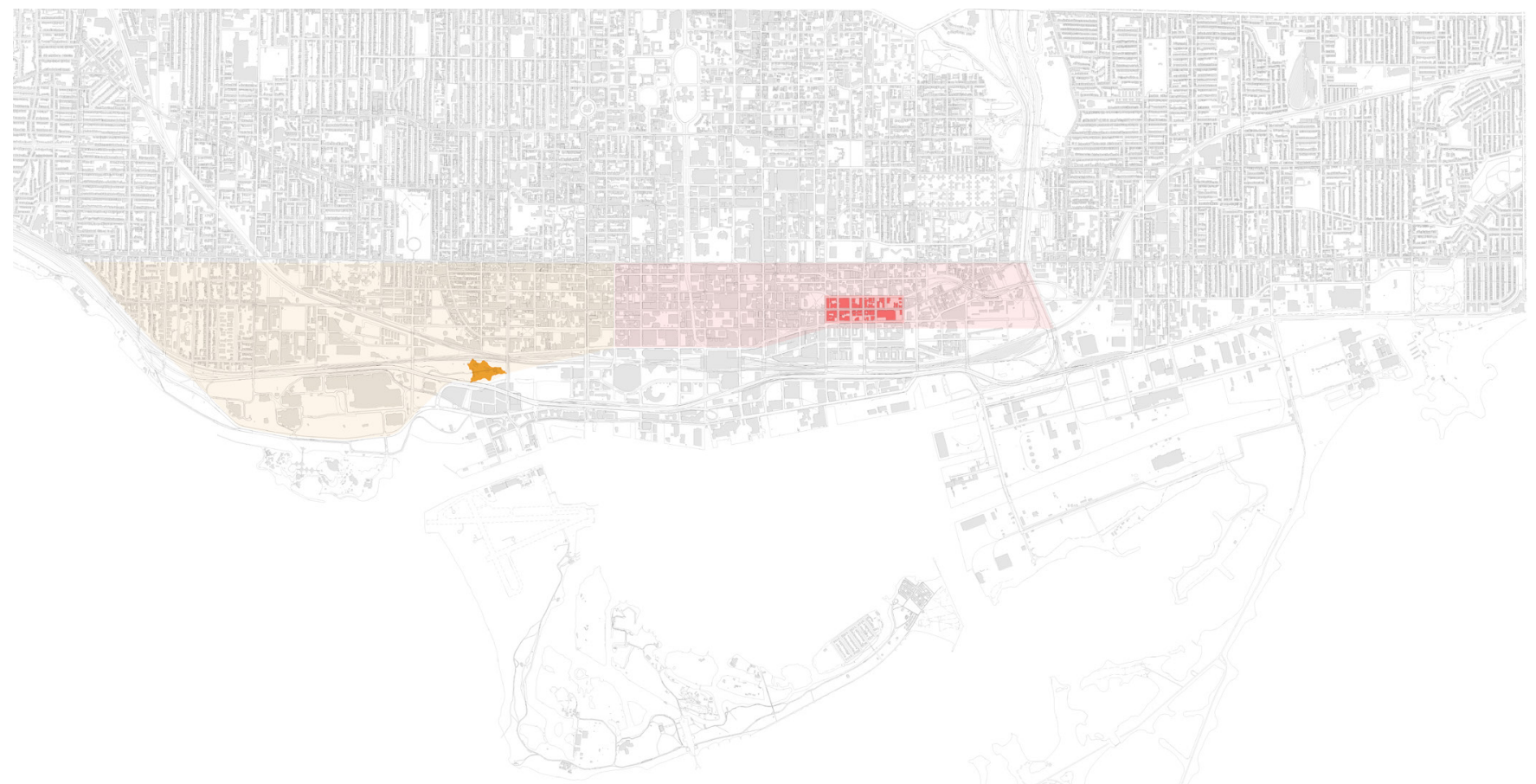

Pre 1800

○

Fig. 7: Over the years, the military reserves shrank drastically as the City of Toronto expanded. This diagram shows the Town of York (City of Toronto) in the early 1800's

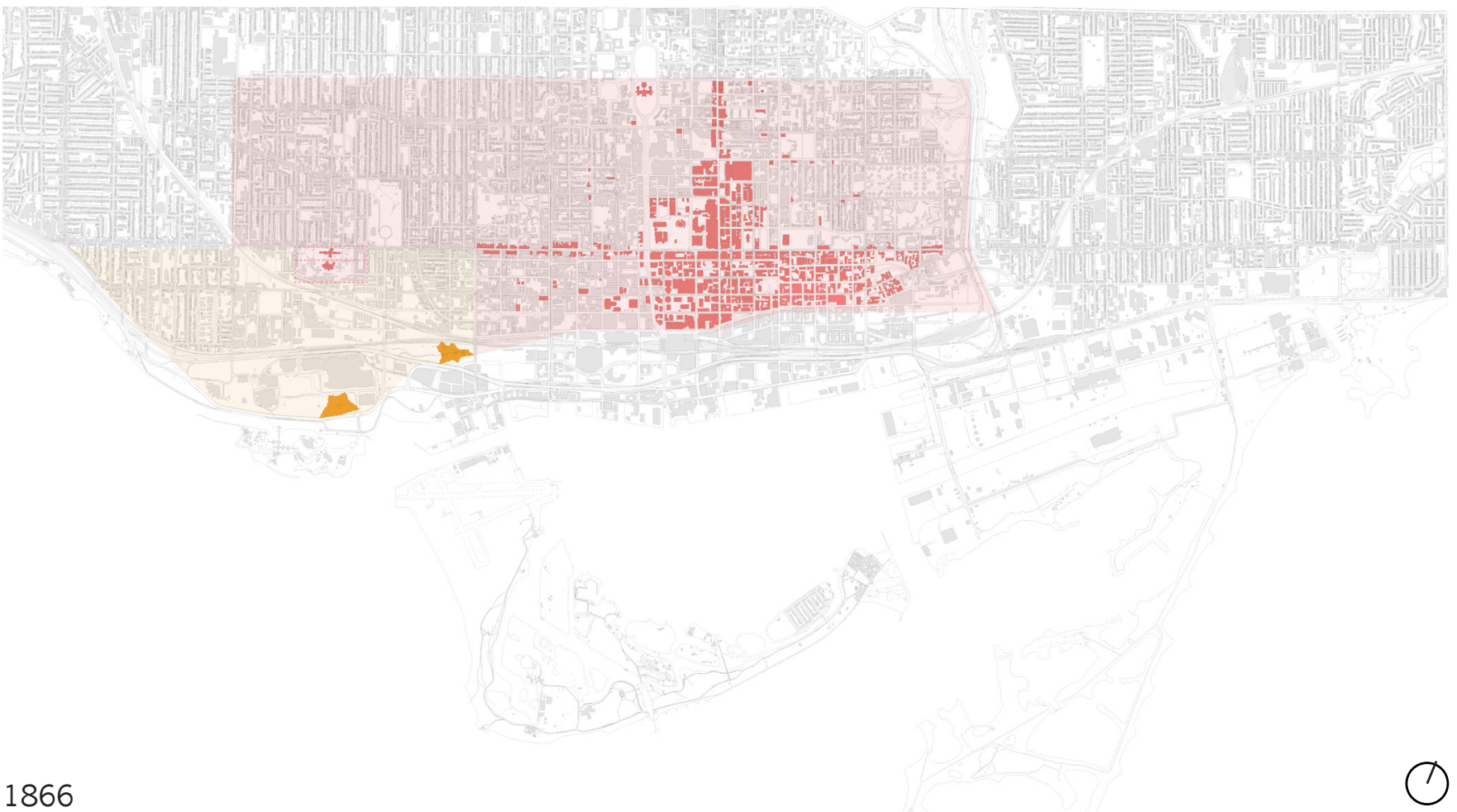

Fig. 8: Diagram showing the Town of York (City of Toronto) expansion in 1866, expanding the town to Bathurst Street 


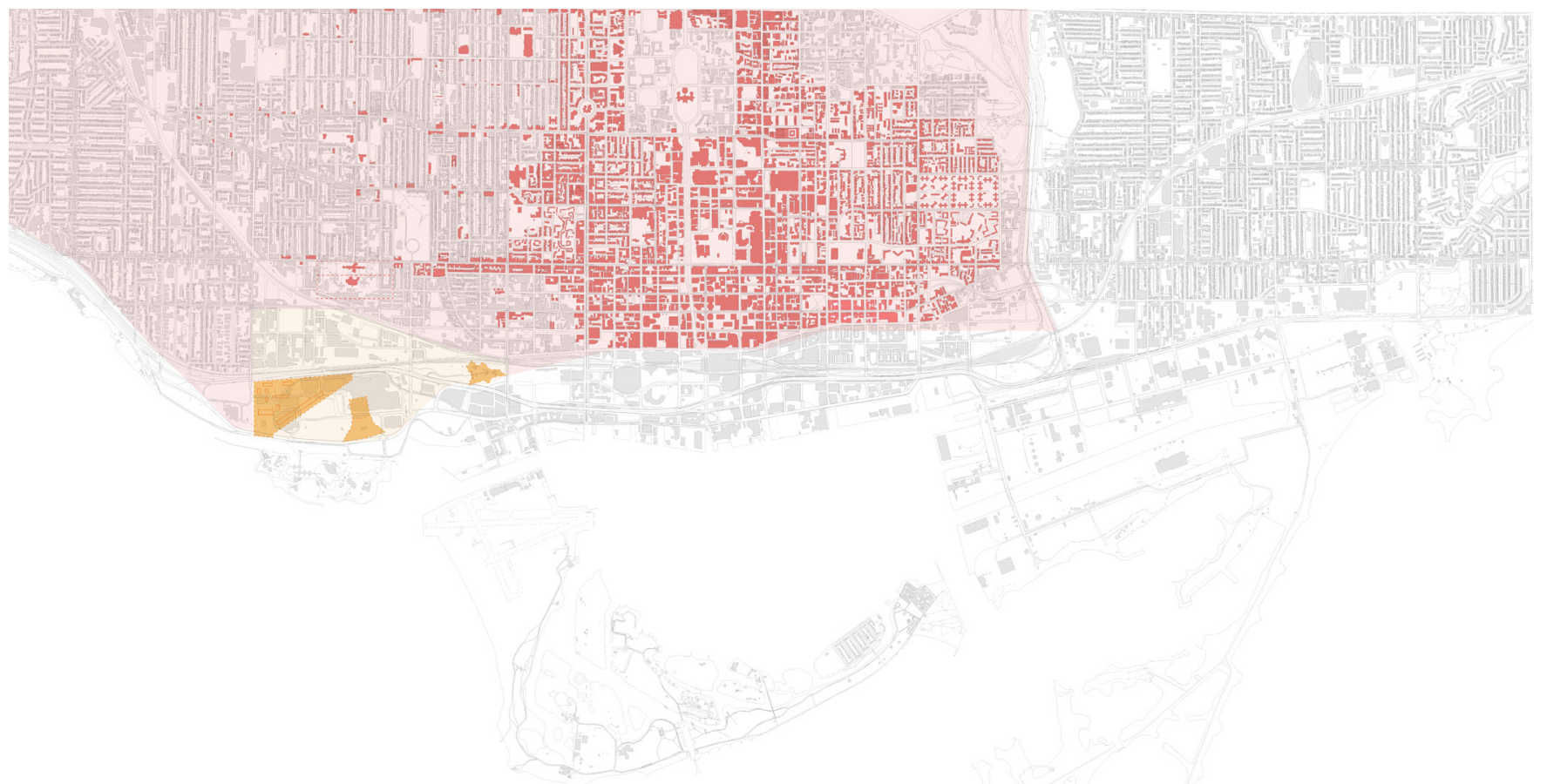

1878

$\varnothing$

Fig. 9: Diagram showing the City of Toronto (formerly the Town of York) in 1878, the construction of the Lunatic asylum on military land, and the new exhibition ground near the New Fort (Stanley Barracks).

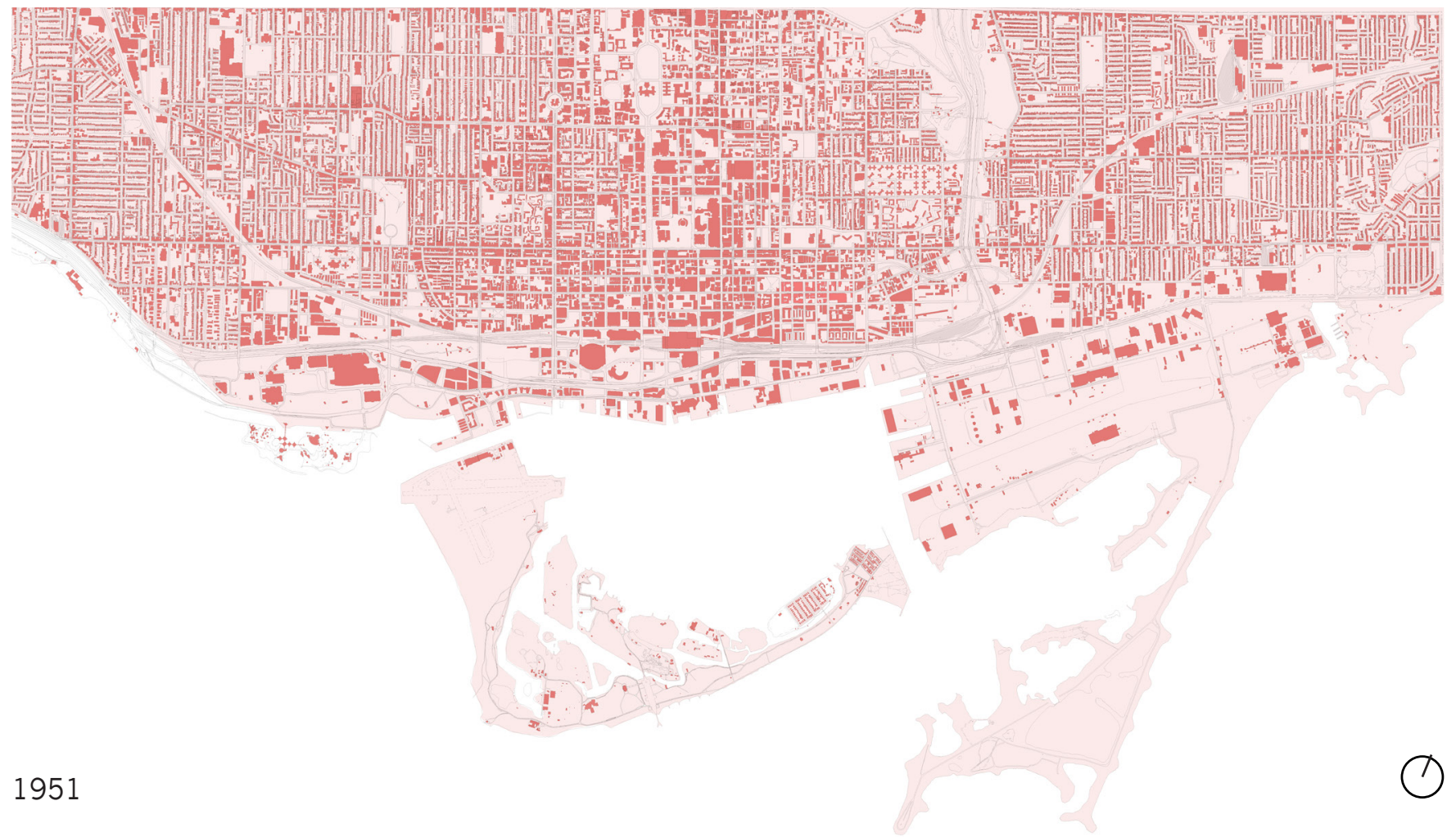

Fig. 10: Diagram showing the demolition of Stanley Barracks and the expansion of the exhibition grounds 


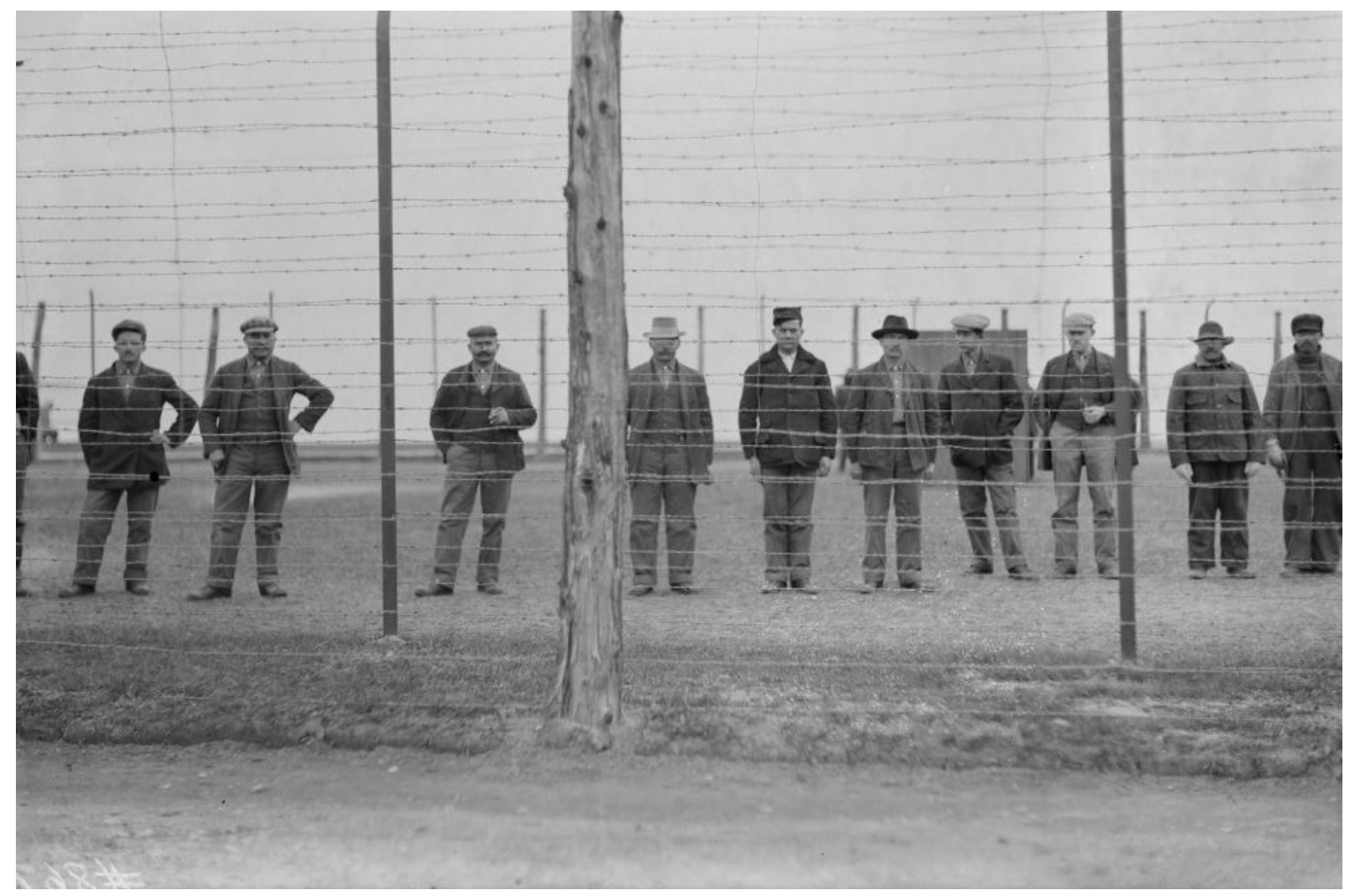

Fig. 11: German prisoners of war temporarily housed at Stanley Barracks during WWII.
In 1893, the New Fort was officially renamed to Stanley Barracks after Lord Stanley, Governor General of Canada. In 1834, the town now a city was also renamed to Toronto (Sendzikas, 2011). In 1878, the Toronto City Council decided to sell and lease the west portion of the military reserve to the Agricultural Exhibition, which was later formed into the Industrial Exhibition, both eventually turning into the Canadian National Exhibition (Sendzikas, 2011).

Over the years, the Exhibition built buildings that encroached onto the Stanley Barracks. By the First World War in 1914, the exhibition grounds along with Stanley Barracks were transformed into a military recruitment and training facility, to house and train over 10,000 new troops (Sendzikas, 2011). It was also a concentration camp, for German prisoners of war before they were transferred to Bowmanville POW camp. The exhibition grounds along with Stanley Barracks were occupied by the military even after the First World War, and into the Second World War, where once again it was a recruitment and training Camp.

It was not until the end of the Second World War, in 1946, that the military was forced out of Stanley Barracks by Toronto City Council (Sendzikas, 2011). The City saw the economical potential of the Canadian 

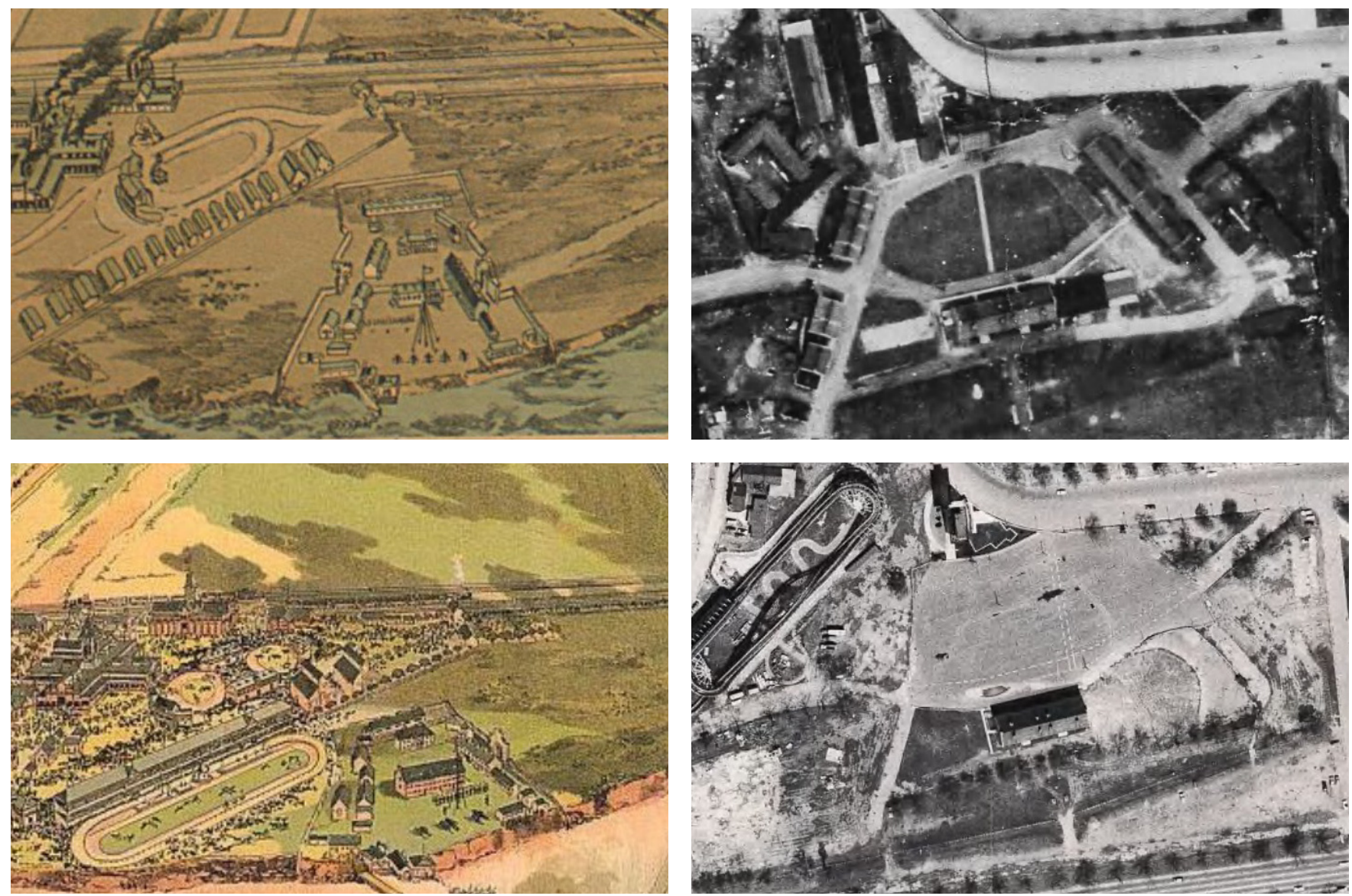

National Exhibition and wanted to demolish all the buildings. However, major urban centers throughout Canada were facing a housing shortage (Sendzikas, 2011). In 1947, after the military moved out, the barracks were transformed into temporary social housing.

By 1950, the residences were evacuated from the barracks and the city began to demolish the fort. There were objections to the demolition of Stanley Barracks especially by Governor General Vincent Massey who opposed the demolition (Sendzikas, 2011). By 1953, all but the Officers' Barrack were demolished to make way for a parking lot. In 1955, Toronto Civic Historical Committee was appointed by the City of Toronto to take control over the Officers' Quarters. It was not until 1998, the building was designated as a historic building.

Stanley Barrack shaped the military history of Canada, however Toronto City Council did not see this value. Due to economic reasons and the interest of the city, Stanley Barrack was demolished. This reason alone has caused many significant buildings throughout Toronto to be demolished. Yet the importance of the story of the Stanley Barrack is unquestionably important to the larger history of Canada. 


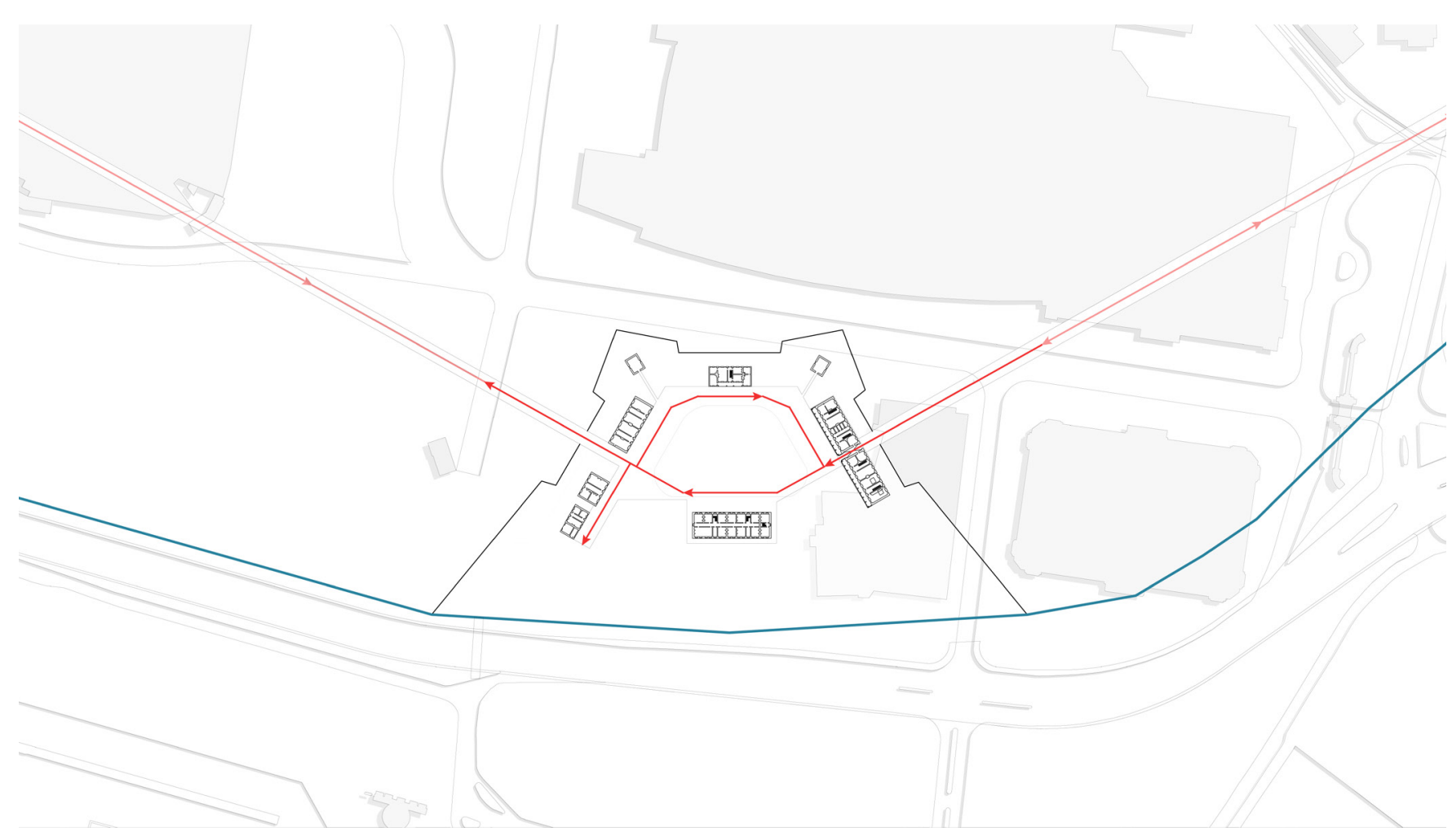

1840

○

Fig. 16: Diagram of historical pathway and circulation in 1840

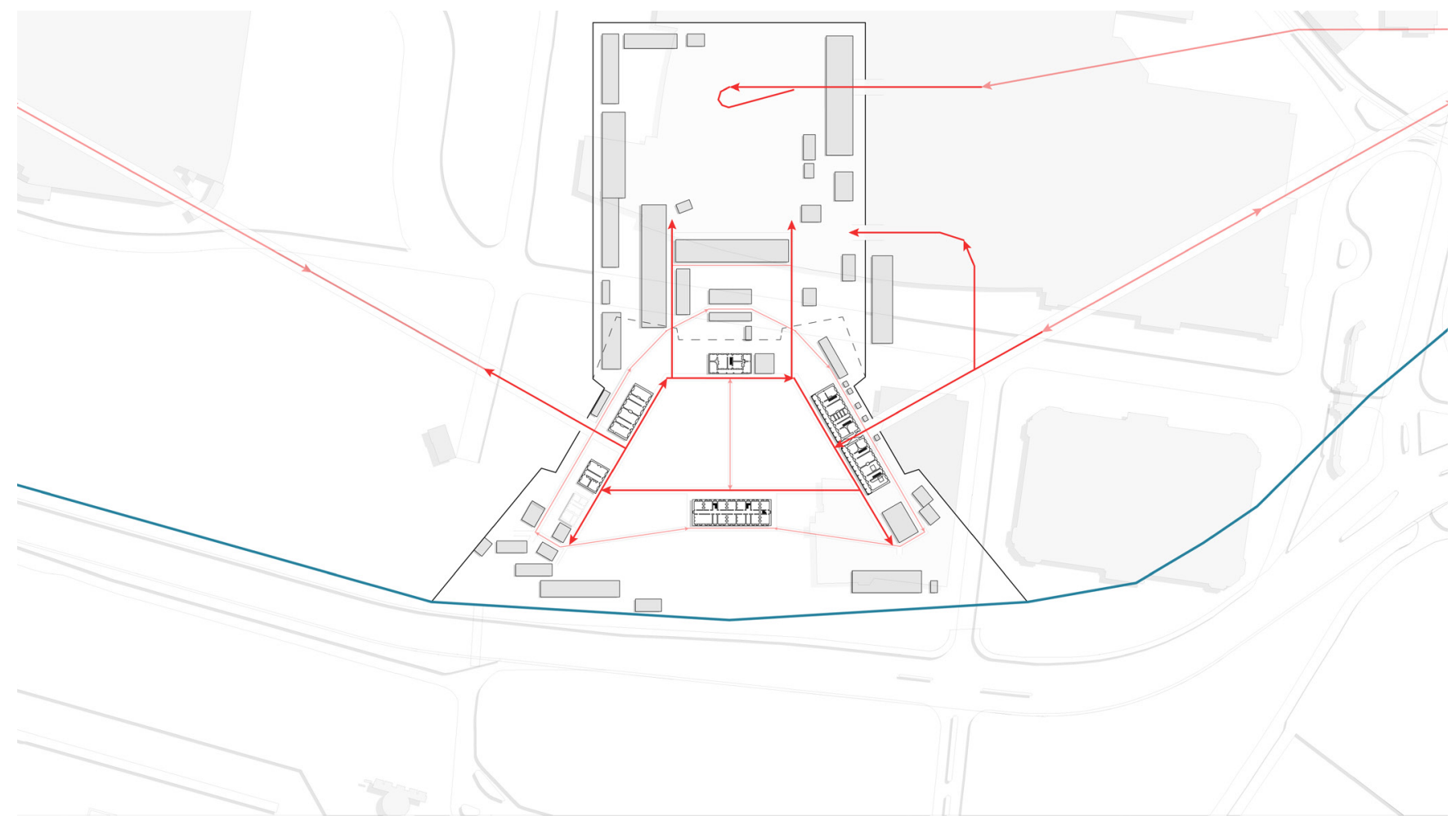

Fig. 17: Diagram of historical pathway and circulation in 1880 


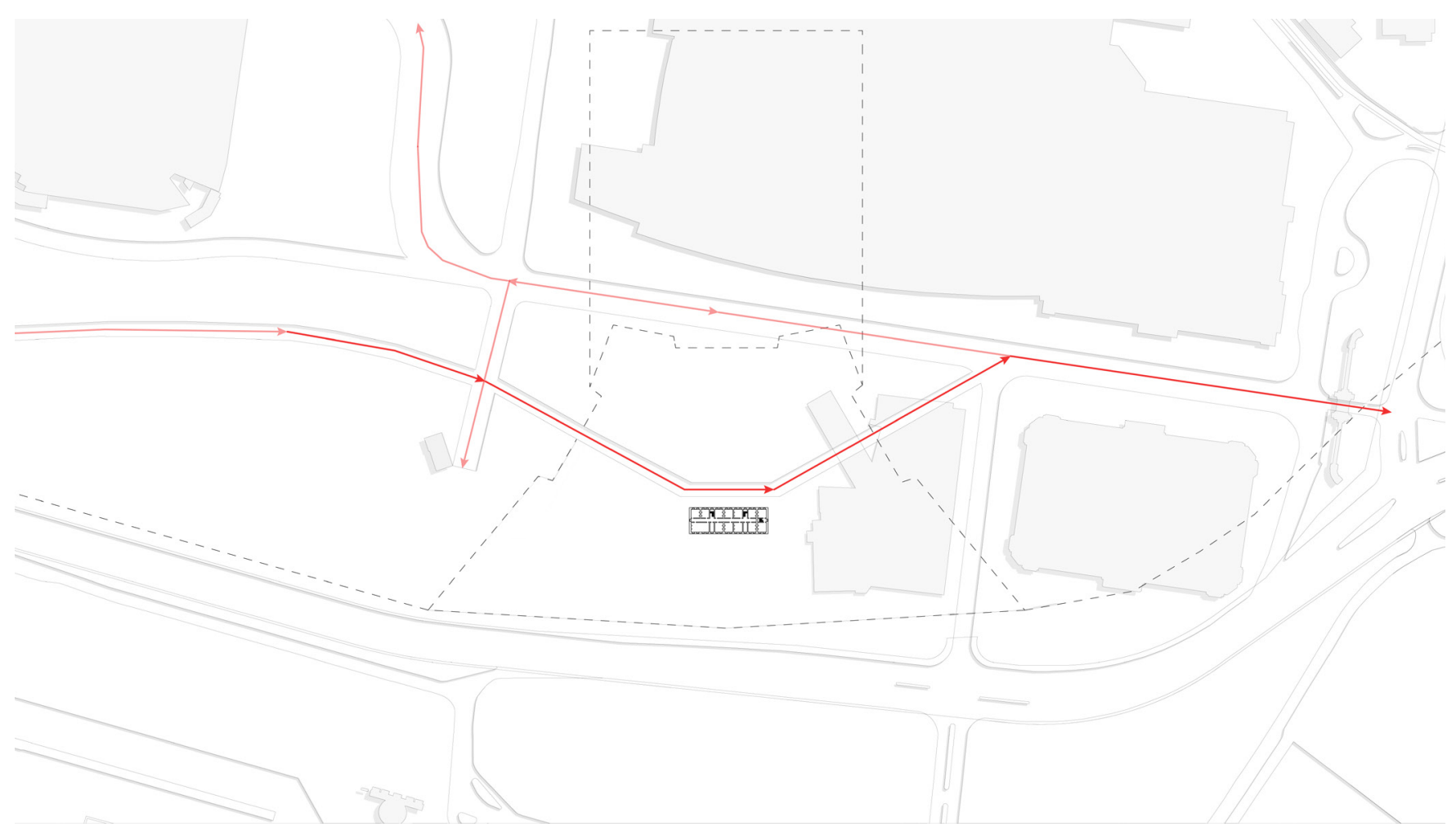

1950

(1)

Fig. 18: Diagram of historical pathway and circulation in 1950

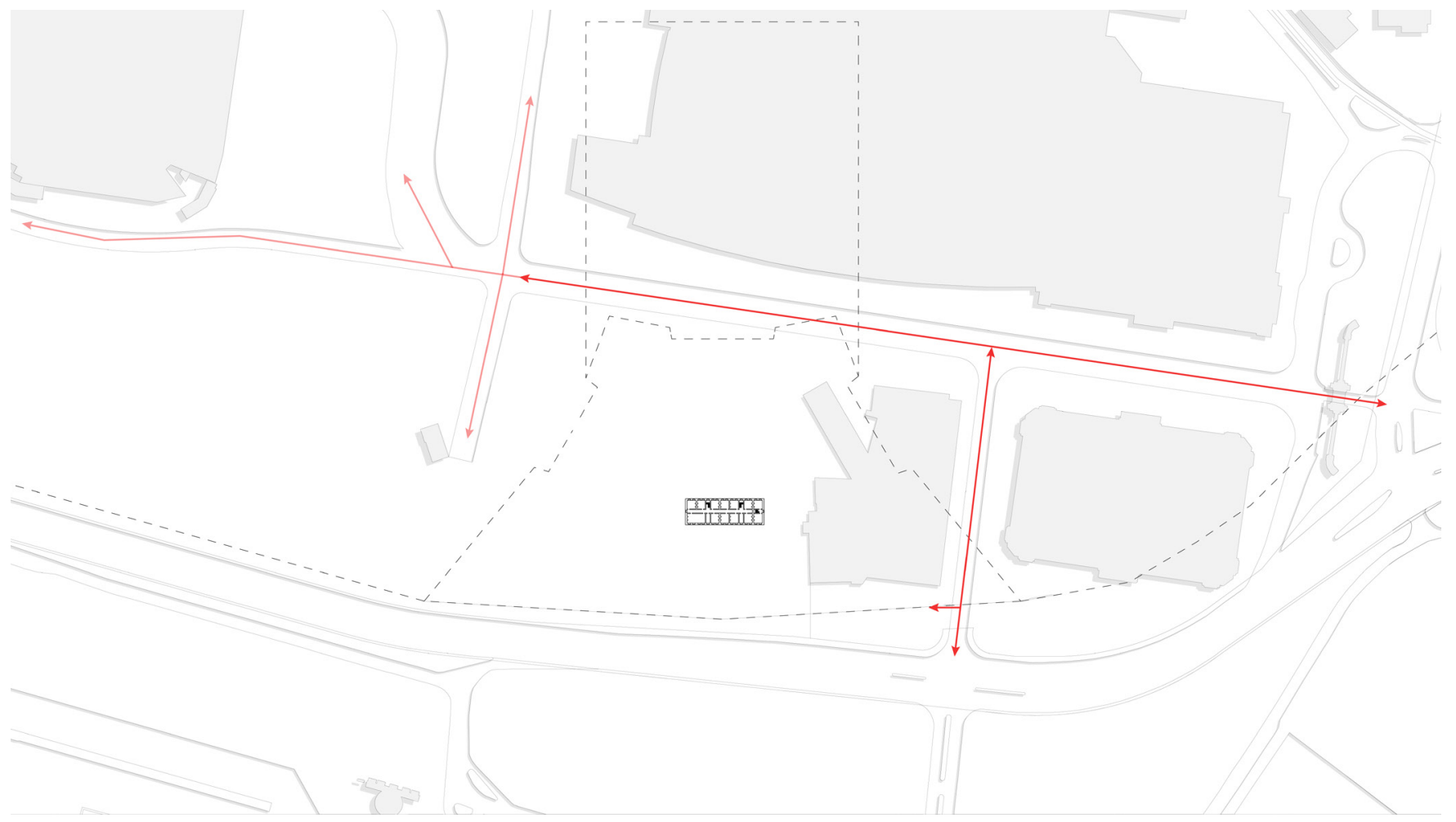

\section{Present}

Fig. 19: Diagram of historical pathway and circulation of the present 


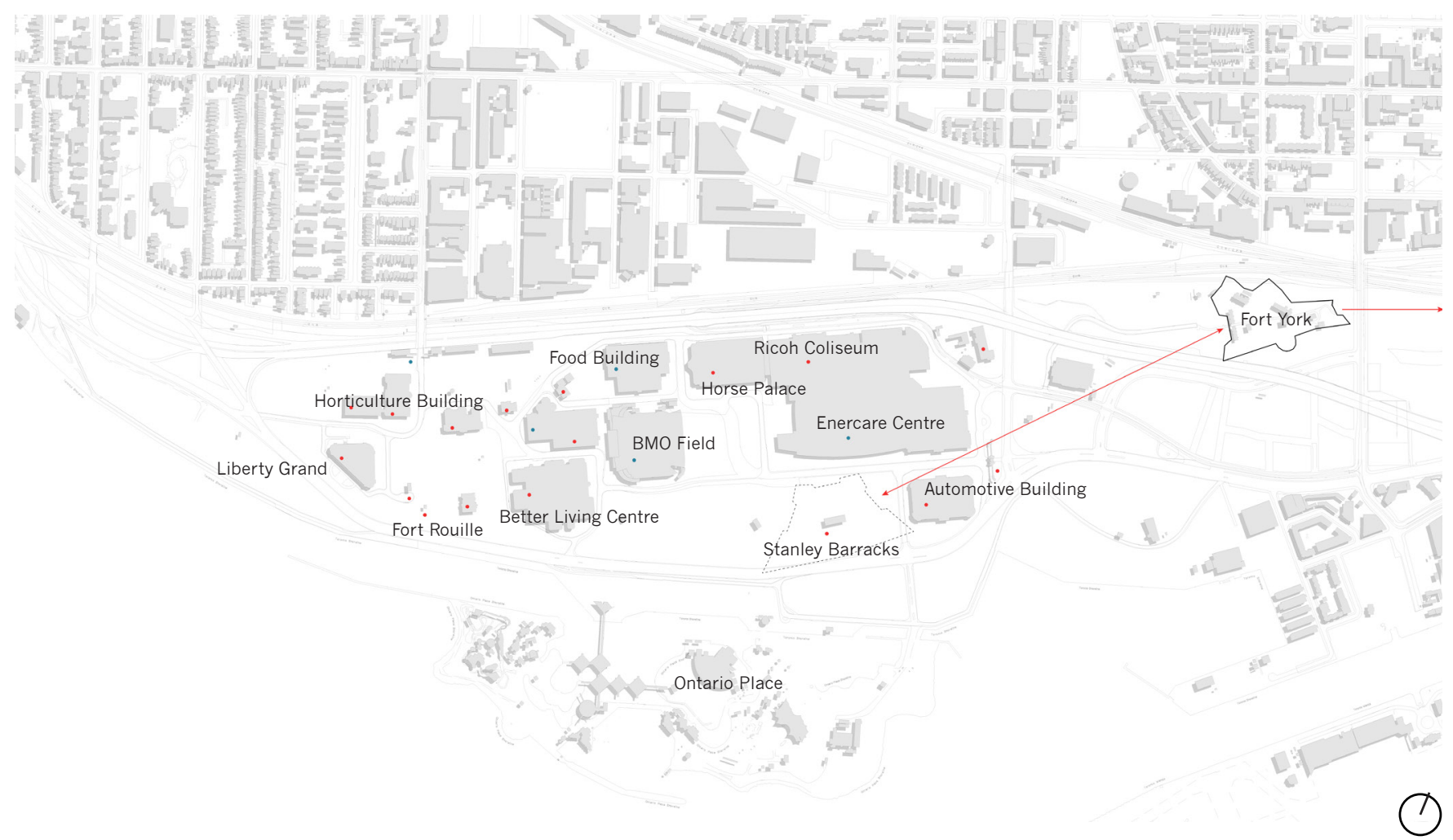

Fig. 20: List of designated buildings at the Exhibition Grounds

\subsection{The Future of Stanley Barrack Site Analysis}

The Officers' Quarters of Stanley Barracks is currently located in the middle of a parking lot at Exhibition Place Grounds. To the north of Stanley Barracks, is the Direct Energy Centre and to the east is the Allstream Centre (formally known as the Automotive Centre). The Exhibition Place Grounds has a number of designated structures: The Princes' Gate, Richo Coliseum, Food Products Building, Railway Building, Ontario Government Building, Horse Palace, Horticulture Building and John Scadding Cabin.

The original shoreline that exists today is not the same shoreline that existed when Stanley Barracks was built in 1840. In 1700, the original shoreline came up to Front Street. By 1780, the water began to recede exposing the western shoreline of Toronto and revealed marshland at the eastern shoreline. From 1850's to the 1920's, land reclamation programs created new docks along Front Street and the creation of the Port Lands and land infill to Toronto Island. By the mid 1950's new land was exposed as water receded and land reclamation continued creating 


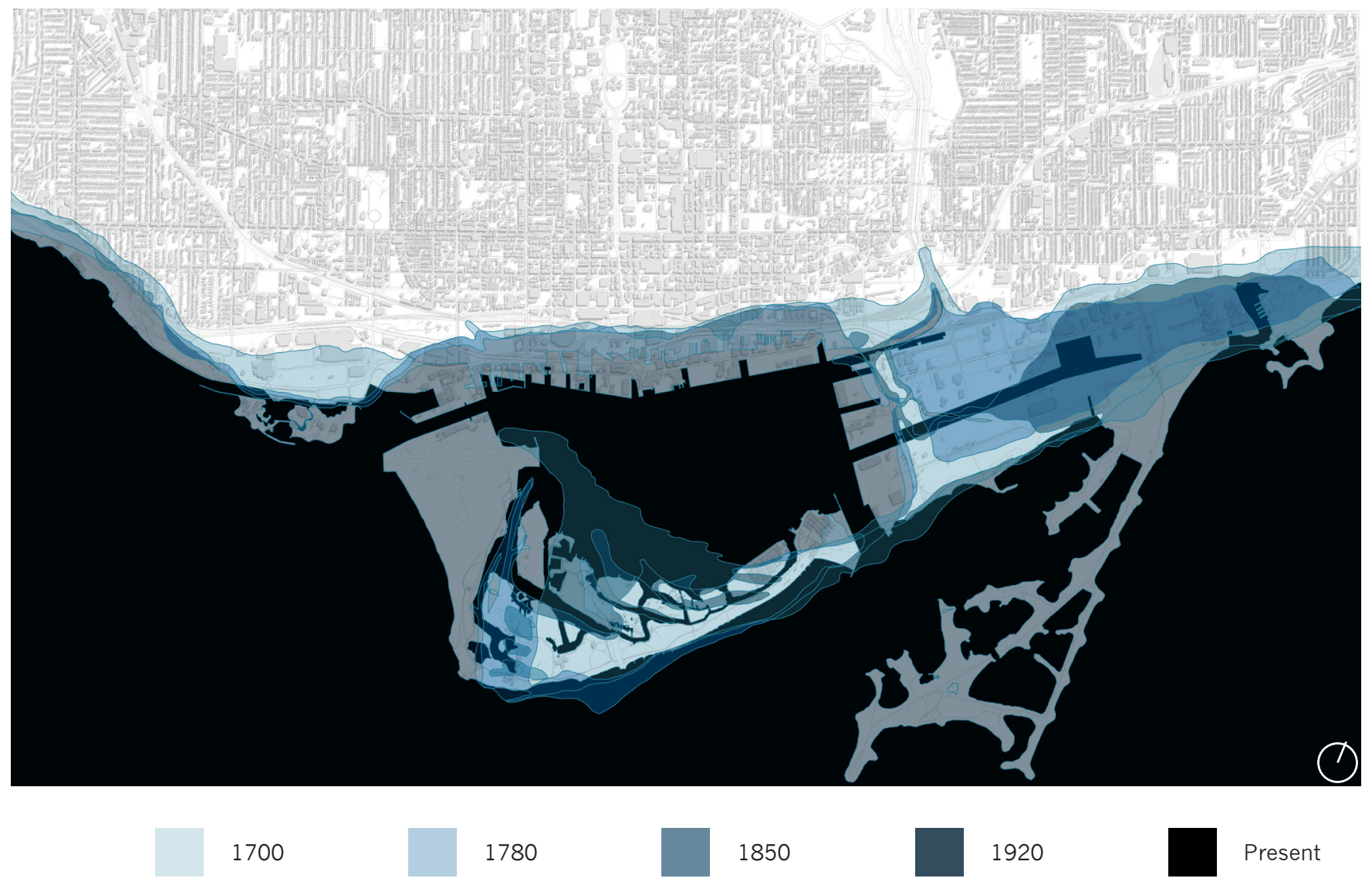

new opportunities for development. Stanley Barracks and Fort York no longer shared a relationship with the water as the water receded.

The Canadian National Exhibition Place is no longer at the periphery of City of Toronto. It is surrounded by different neighborhoods. Directly north, cut off by the Gardiner Expressway and the Railway Tracks is Liberty Village. It has become a prominent new mixed-use neighborhood. To the west is Parkdale, and east is the new neighborhood of Fort York, which has grown recently in the last 10 years. To the south is Lake Shore Boulevard and Ontario Place.

The main circulation of Exhibition Place is though the Princes' Boulevard that goes though the grounds from Strachan Avenue to Dufferin Street. There are also a secondary accesses from Lake Shore Boulevard. Exhibition Place also has access for public transportation from the north side, by both streetcar and the GO train. Exhibition Place is hard to access on foot as there is no access along Lake Shore Boulevard. Pedestrians can either access from Strachan Avenue though Princes' Boulevard or from Duffrin Street. Maintaining a north-south pedestrian route is important to Ontario Place from Exhibition, which a walkway is used to connect both locations.
Fig. 21: Diagram of Toronto shoreline from 1700 to the present 


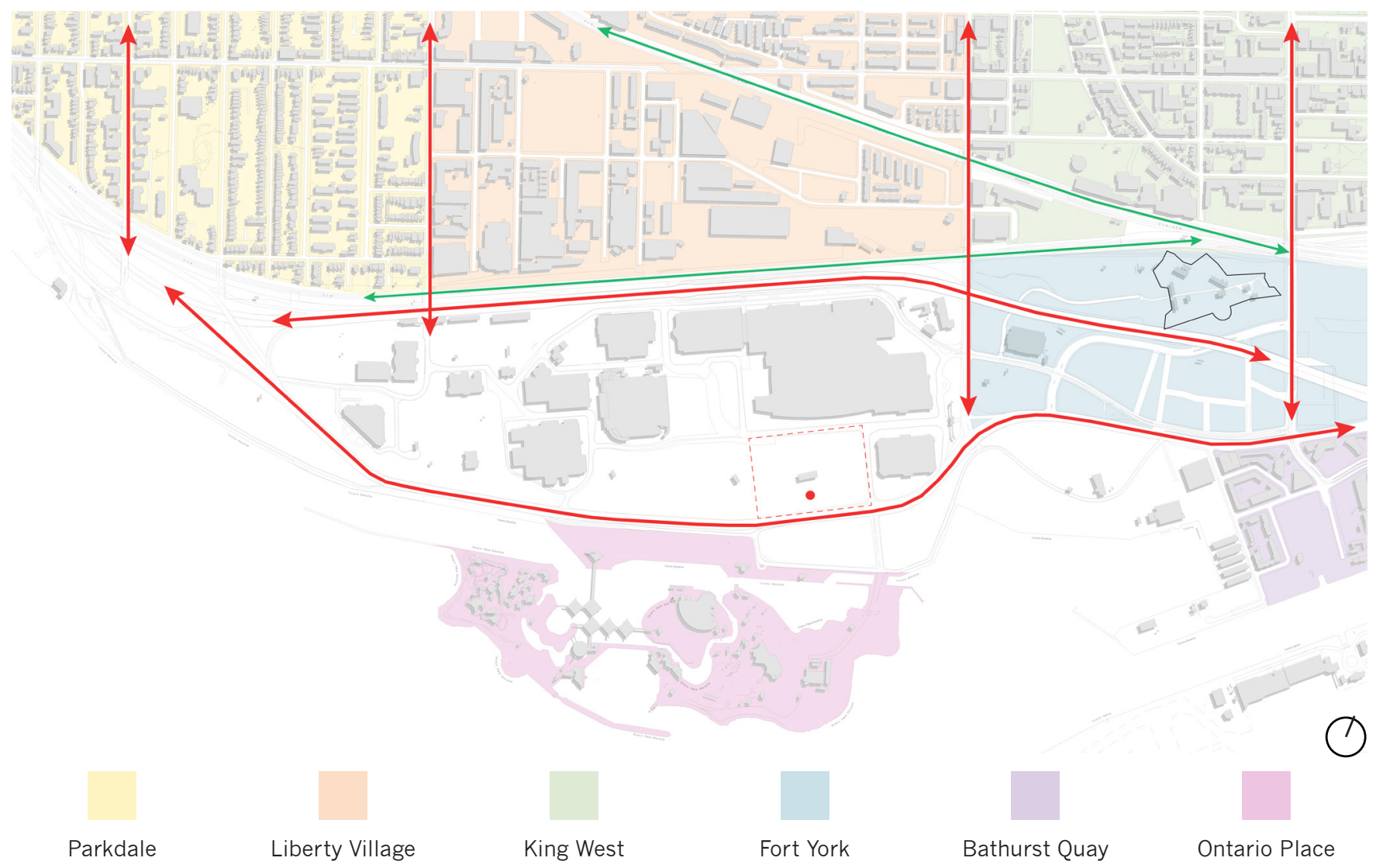

Neighbourhoods around Exhibition Place

Fig. 22: Diagram of surrounding neighbourhoods around Stanley Barracks

\section{Opposite}

Fig. 23: Diagram of circulation around Stanley Barracks

Fig. 24: Diagram of pedestrian circulation around Stanley Barracks
In 2012, a property developer proposed a two-phase hotel development along with additional conference rooms and convention spaces on Stanley Barracks grounds, east of the Officers' Quarters. The first phase is a 29-story luxury hotel with 5-acres of park space to be created (City of Toronto, City Council Briefing, 2014; Lewington, 2009). The hotel will include 410 suites estimating in total of 71,000 sq. ft. sport facility and recreational space. The developers wanted to make the current convention center more competitive for convention business (City of Toronto, City Council Briefing, 2014; Exhibition Place, 2014; Lewington, 2009). The location of buildings for the second phase is currently unknown.

The hotel development is part of a larger vision for Stanley Barracks and Exhibition Place. Exhibition Place plans to expand BMO Field, it will extend its eastern grandstand, with a large undercroft, which will be used to enhance the amenities of Exhibition Place (Exhibition Place, 2011). There is also a plan to expand the western portion of the Direct Energy Centre that will provide more opportunity for future events like the Honda Indy and better pedestrian access (Exhibition Place, 2011). A Festival Plaza is also proposed on the western most portion of the parking lot (Exhibition Place, 2011). This will create space that is flexible for a mix of gatherings and celebrations. 


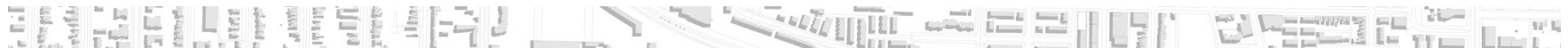
明

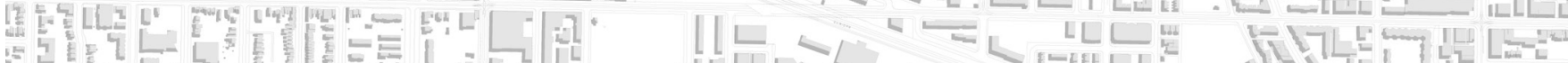

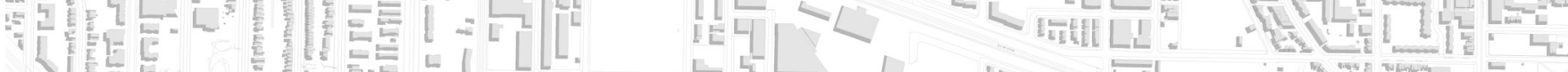

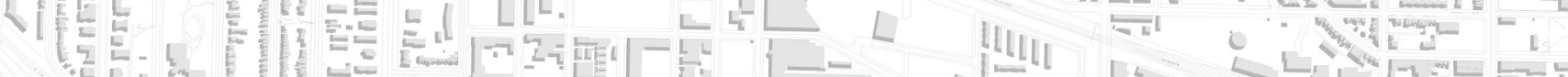

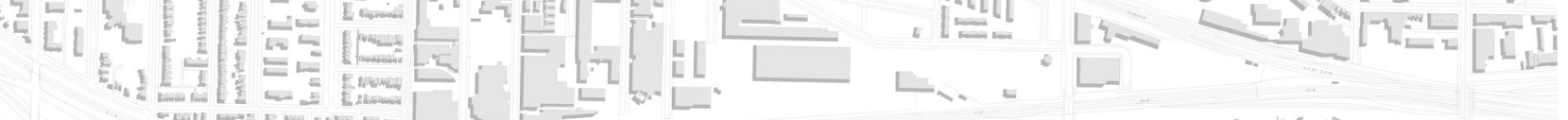
8

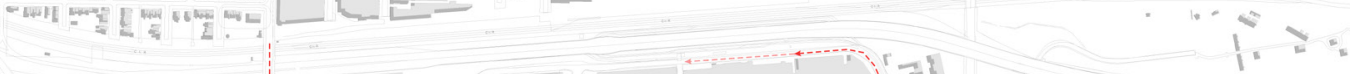

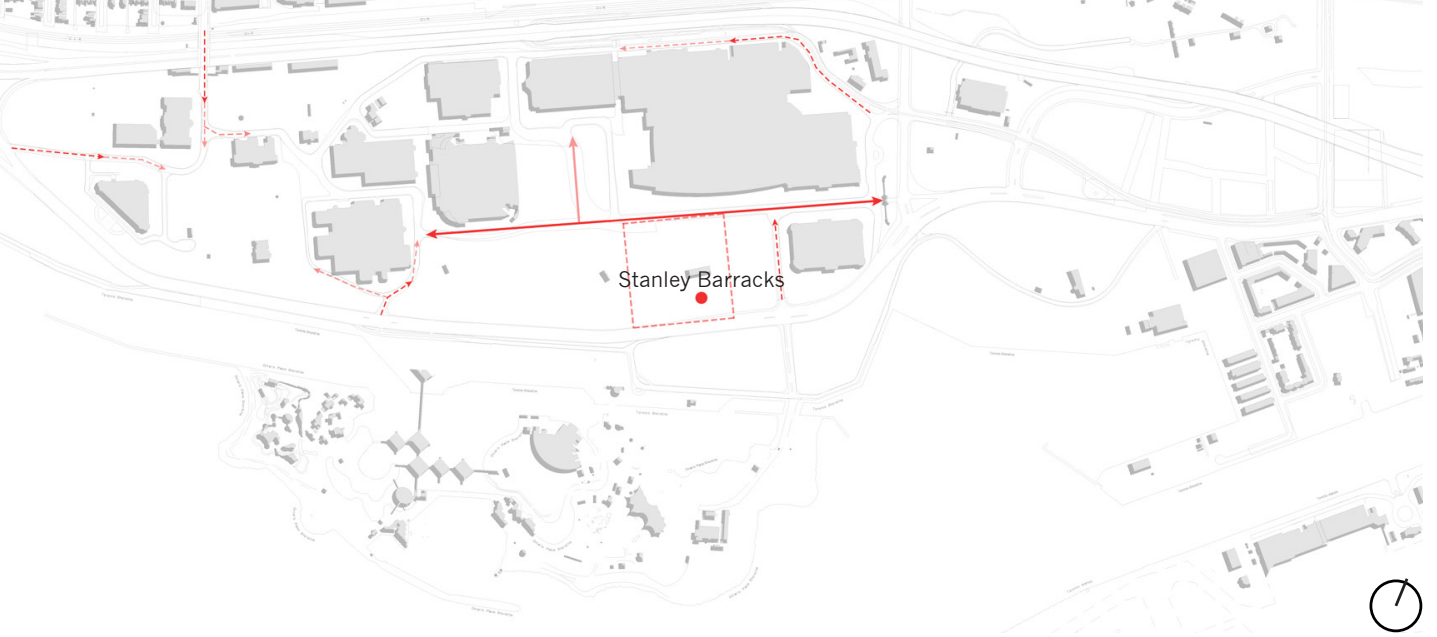

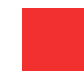

Circulation

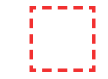

Proposed Site

Site Circulation

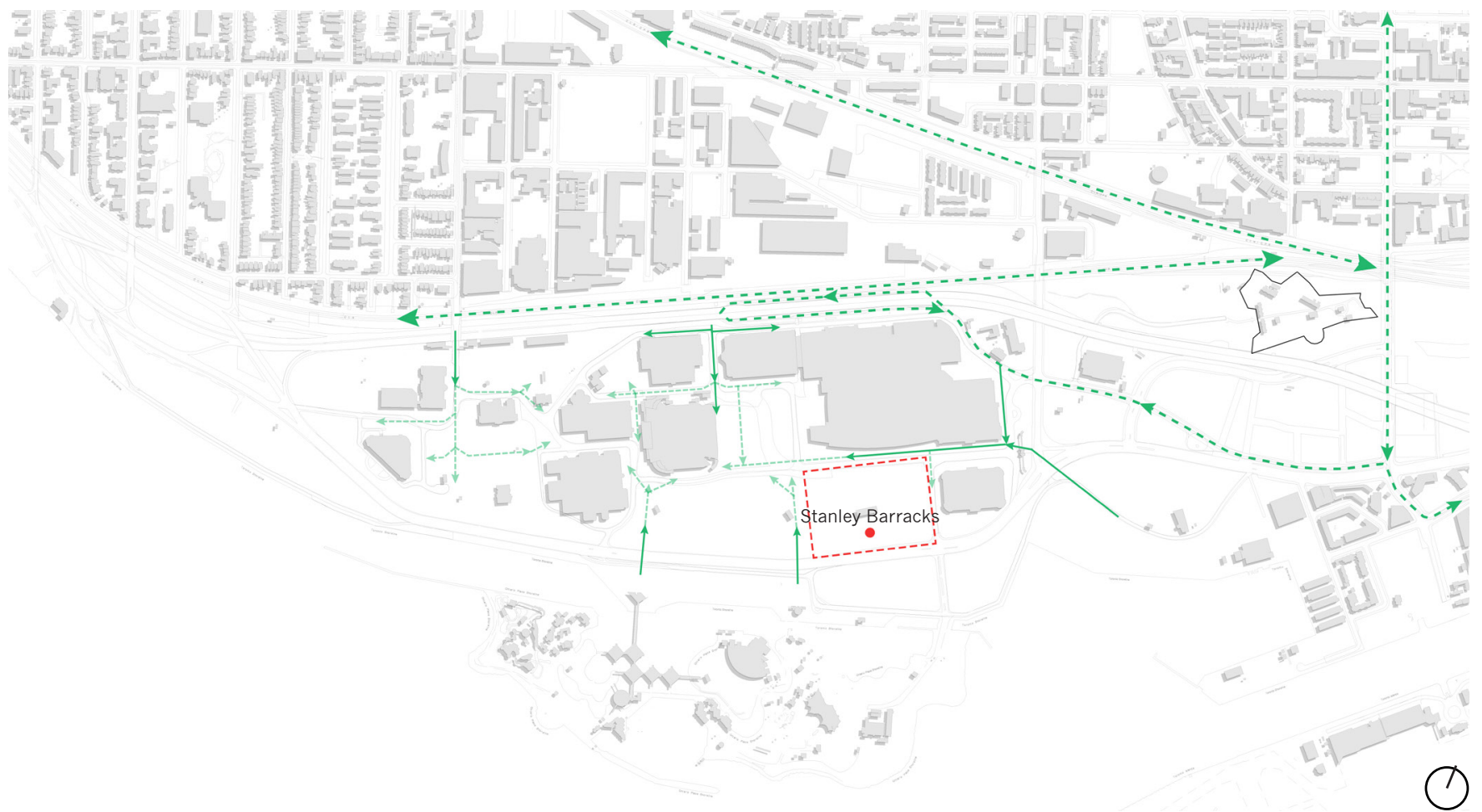

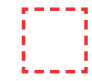

Proposed Site

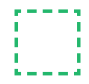

Public Transit Circulation

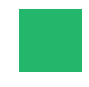

Pedestrian Circulation

Pedestrian Circulation 


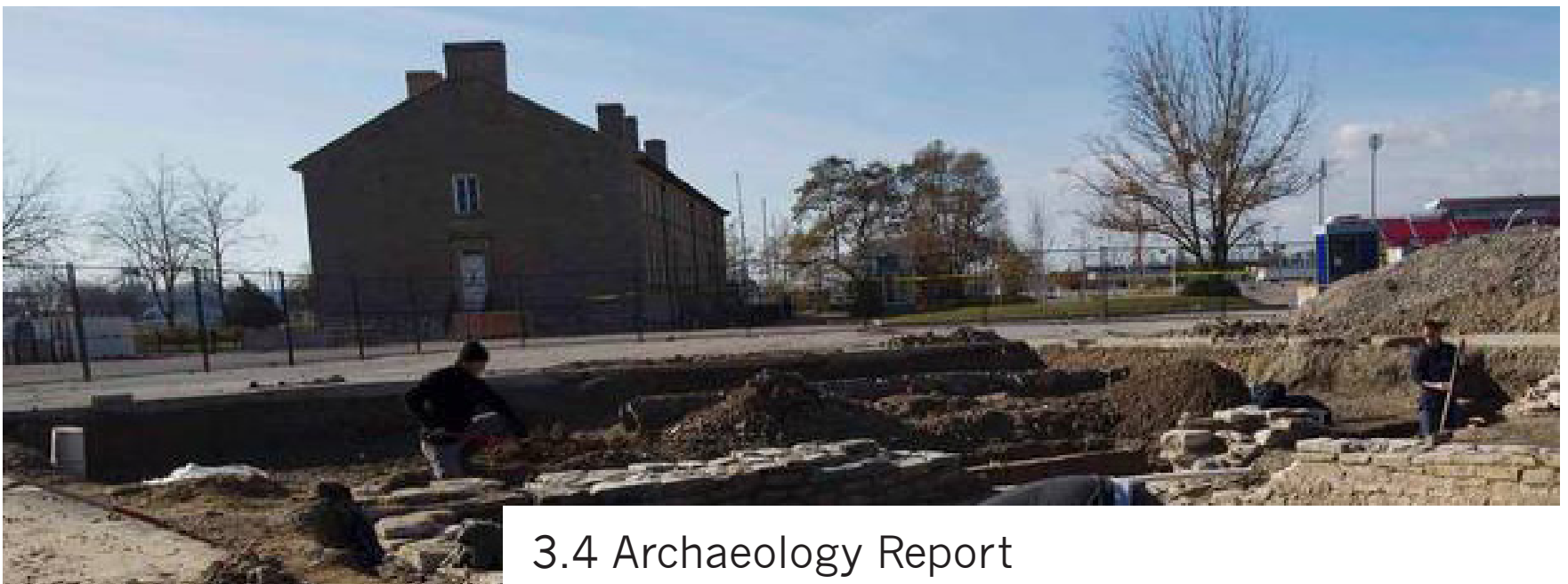

An archaeological study was commissioned by the developers of the site to get a greater understanding of what traces remain underneath the parking lot at Stanley Barracks. Toronto City Council, as well as the Fig. 25: ASI archaeological investigation of Stanley Barracks looking south

Exhibition Place Board of Governors, required the developers to preserve the archaeological evidence that remained underneath the design.

The archaeological study was part of a series of investigations that occurred at Stanley Barracks. In 2004, Archaeological Service Inc. was contacted to determine the archaeological potential on the grounds of Stanley Barracks. In total eight trenches were placed in the parking lot. During the excavation, stonewalls, foundation footing, drainage and builders trench were found, dating back to 1840's (Archaeological Serice Inc., 2014; Archaeological Serice Inc., 2009). Artifacts dating back to the late 19th century were also found inside the trench.

In 2008, additional trenches were excavated and an 1861 addition to the barrack building was discovered. The wooden structure alone, with a series of posts and artifacts, dates the site to the late 19th to early 20th century (Archaeological Service Inc., 2019).

In 2012 a stage 4 archaeological investigation occurred at the east side of Stanley barrack, which uncovered the remains of old building foundations. They have identified it to be Privates' Barrack No. 1, the

Opposite Clockwise

Fig. 26: ASI archaeological investigation of Stanley Barracks looking North

Fig. 27: ASI archaeological investigation of Stanley Barracks looking East

Fig. 28: Archaeological artefacts uncovered during archaeological investigation

Fig. 29: Stone well uncovered during archaeological investigation

Fig. 30: Plan of archaeological investigation trenches at Stanley Barrack larger of the two barracks. Majority of the traces that remains were underground cellars, foundation walls and archaeological artifacts.

The proposed hotel includes these ruins in its design, by preserving them under a glass walkway, allowing visitors to view the ruins from above. It seems at in the end, the hotel was required to incorporate the ruins, in order to build on the site. The archaeological site becomes an afterthought which does not relate to the over all hotel narrative. 

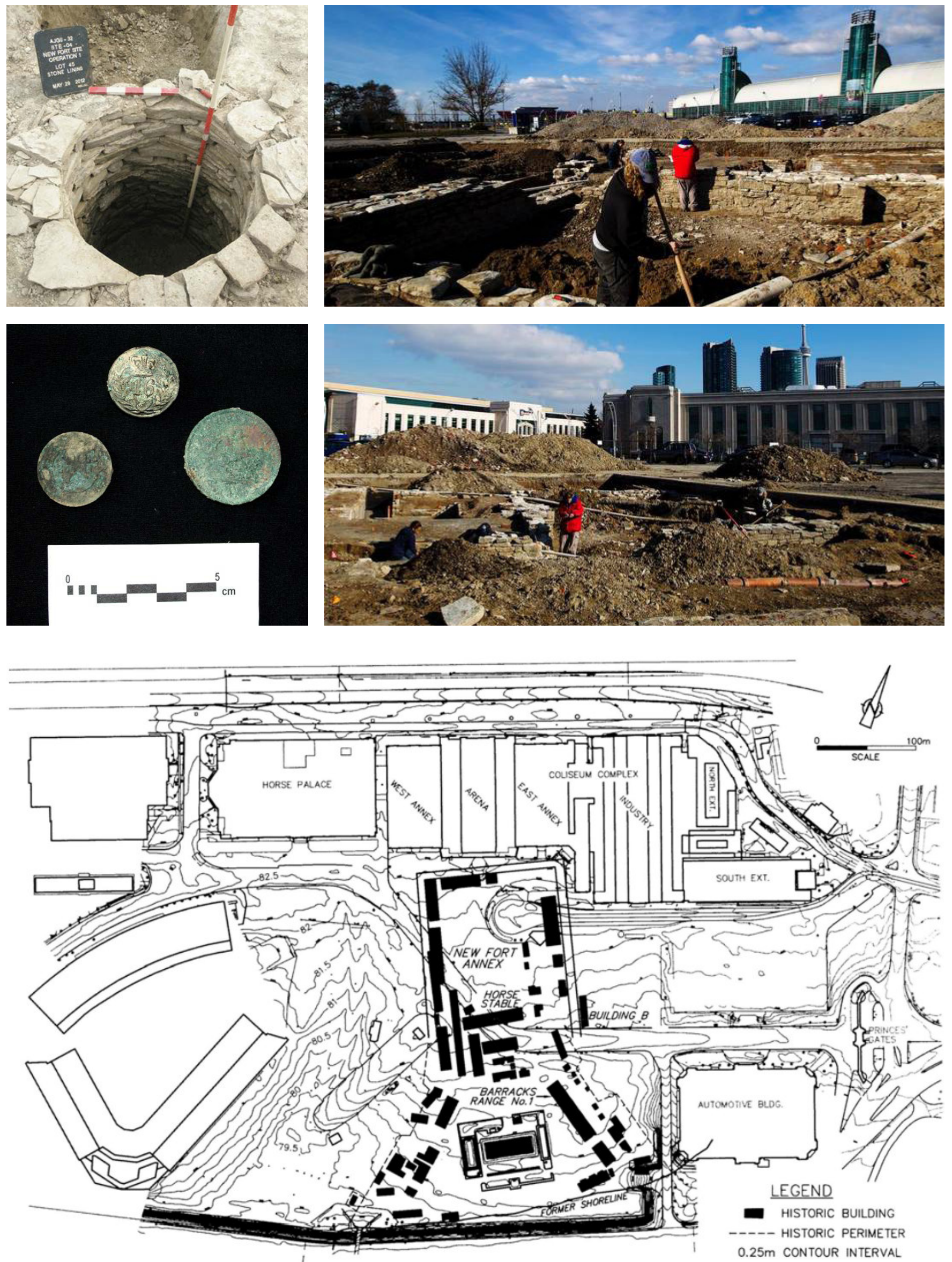


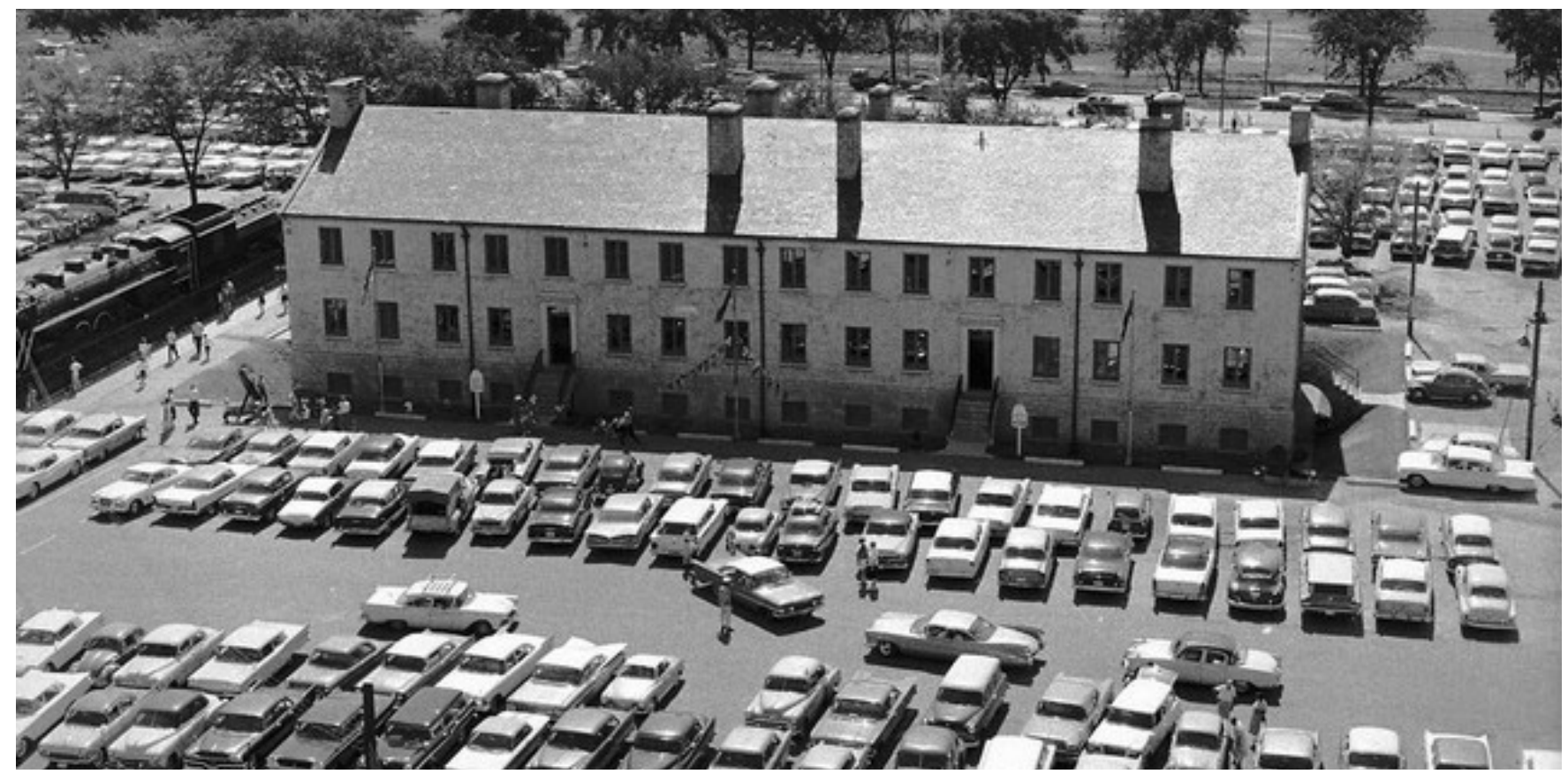

Fig. 31: Officers' Quarters in the mid 1950's surrounded by a sea of parked cars.

\subsection{Design Proposal}

Stanley Barrack located at Exhibition Place has been neglected for over 50 years. After the demolition of all but the Officers' Quarters, the history of the site has been forgotten. Under the parking lot are layers of history dating back to the founding of the City of Toronto and Canada. It is possible to assume then, within the grounds surrounding Stanley Barracks and west of the Officers' Quarters, that there are traces which can help reveal the layers of palimpsest.

I propose a museum at Stanley Barracks over the original site of Privates' Barracks No. 2, the Canteen and the Master Storeroom. The museum will incorporate the traces that remain, both tangible and intangible, as part of the design. The use of palimpsest will be a key concept, which will be conveyed though the design. The museum will respond and reveal the complex layers of palimpsest that is associated with the Stanley Barrack. The role of the museum is a space that will go beyond representing the military theme to reveal the layers of palimpsest that exist.

The current value of Stanley barracks relies on its military identity. In particular for its associations with the military history of Toronto and Canada, including the events, people, activities and organizations linked to the site for more than a century.

In order to not preserve, maintain or create another typical museum space with the current value that was identified, the following three 


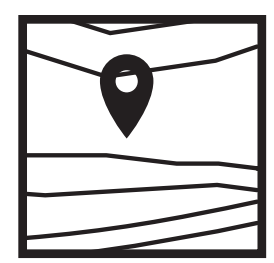

Strategy 1

Identify the Value

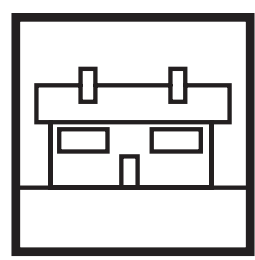

Strategy 2

Connect the Narrative

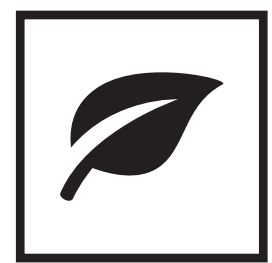

Strategy 3

Craft Details and Materiality

strategies will help guide the design: first, identify and respond to common themes of 'value'; second, provide opportunities to connect the narrative and experience to the individual; and third, create a dialog Fig. 32: 3 Strategies to help reveal the palimpsest in architecture, (left) identify the value, (middle) connect the narrative, (right) craft detail and materiality and materiality. The architecture should reveal the layers of palimpsest of Stanley barracks into a new narrative that people can experience within a place. It seeks to reveal the palimpsest that exists on the site that goes beyond just representing the military theme.

\section{Strategy 1}

Identify and respond to common themes of 'value' of the past present and future.

\section{Tactic 1}

Identify character-defining elements that contribute to the 'value'

\section{Tactic 2}

Respond to the themes of 'value' in abstract terms.

According to the Toronto Council reports, the value of the officers' quarter at Stanley Barracks was already identified. It states that:

“The Officers' Quarters, Stanley Barracks has cultural heritage value as a rare and unique early 19th century military structure in Toronto and one of the oldest extant buildings in the city. The building is particularly distinguished as an early expression of the Georgian style in Toronto that displays solid stone craftsmanship and both original and restored features. With Historic Fort York, the National Historic Site to the east, the Officers' Quarters, Stanley Barracks is an integral part of the small surviving collection of historic buildings in Toronto that demonstrates the city's military history.

The Officers' Quarters, Stanley Barracks has value for the site's 
historical associations with the Royal Engineers, the corps of the British Army responsible for the design of military installations in Canada prior to 1870. The Officers' Quarters joins Historic Fort York as significant and rare examples of the work of the Royal Engineers in both Toronto and Canada.

Historically, the Officers' Quarters at Stanley Barracks is particularly valued for its associations with the military history of Toronto and Canada, including the events, people, activities and organizations linked to the site for more than a century..." (City of Toronto, City Clerk's Office., 2014, p. 1).

However, this value relies only on its military identity. Through extensive research there are other values that are associated with the site, especially its relationship with the communities and organization that relied on the military presence and the events and people that link the site to the city and country. There is also a darker side of Stanley Barracks, from its concentration camp to the deteriorating conditions of social housing.

Characteristics that can help define the Barrack's value are the parade square, which is important to not just military training but also to gatherings and social events. The arrangements of buildings and circulation between them and to the city are important; they contribute to how the relationship of the city and military interacted within the space. And finally, the relationship with the lakeshore, which was important for the defense of Toronto and transportation route for the city. Stanley Barracks was designed to withstand attacks from the land but also from the lake. The location of Stanley Barracks relied on its location and defensive position. However over the years, as the water receded and the land was filled, the relationship to the lakeshore has changed.

\section{Strategy 2}

Provide opportunities to connect the narrative and experience to the individuals

\section{Tactic 1}

Lines of narrative, both physical and non-physical (Lines of view, circulation, transition)

\section{Tactic 2}

Connect the narrative and experience

The narrative of the site is important to the experience of the individual. However, a current narrative at Stanley Barracks does not exist. The Hotel $\mathrm{X}$ extension over the archaeological artifacts only represents a 

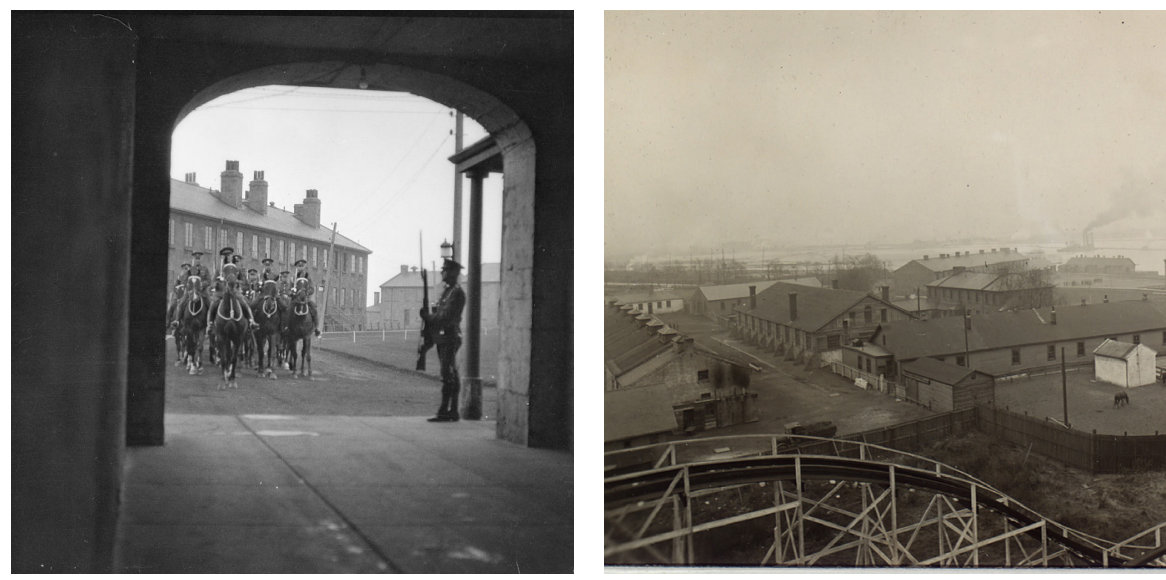

particular palimpsest layer. The museum would build upon the military theme and expand the narrative of the site to incorporate the historical, contemporary and interpretative layers.

The visitors would be able to transition from one layer to another, moving freely to understand the palimpsest that exists. The building will reveal itself as visitors circulate interoperating the site, the building and the details of time. The narrative of the site will become apparent between the building and layers that exist on the site that is built over time creating a rich palimpsest of physical and cultural memory.

\section{Strategy 3}

Create a dialog between the past, present and future through the use of craft details and materiality

\section{Tactic 1}

Create a dialog between the past though the use of materials

\section{Tactic 2}

Respond to the compatibility of the existing and new elements though the use of juxtaposition, overlap, excision, dissection, syntheses and so on

Materials that are used should respond to the existing materials of the past such as brick, wood and stone and also respond to new contemporary urban materials.

The dialogue between the old and new materials are important to reveal the palimpsest. The visual and physical dialogue, that occurs within the space, is important. This visual dialogue occurs between the jagged and crisp edges of old and new elements, and the physical dialogue occurs as elements intersect each other. Using tactics such as juxtaposition, overlap, excision, dissection, syntheses and so on, can create a dialogue between the past and present.

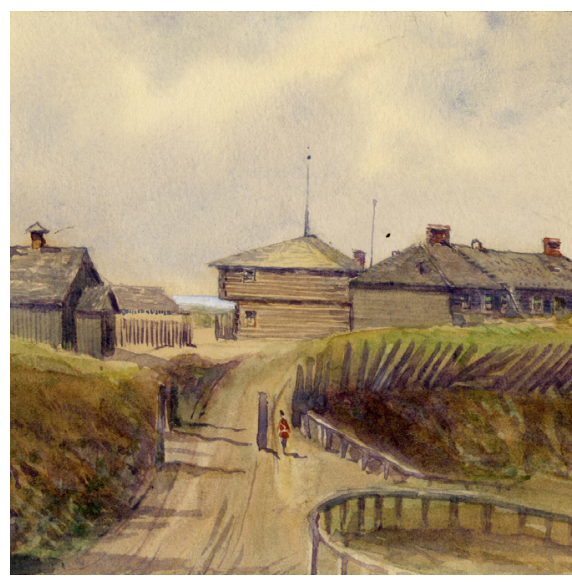

Fig. 33: (left) The Royal Canadian Dragoons leaving Stanley Barracks though the main eastern gate, 1925

Fig. 34: (middle) View of Stanley Barracks from top of switch-back looking onto the city Fig. 35: (right) View of Fort York in water colour 1813 


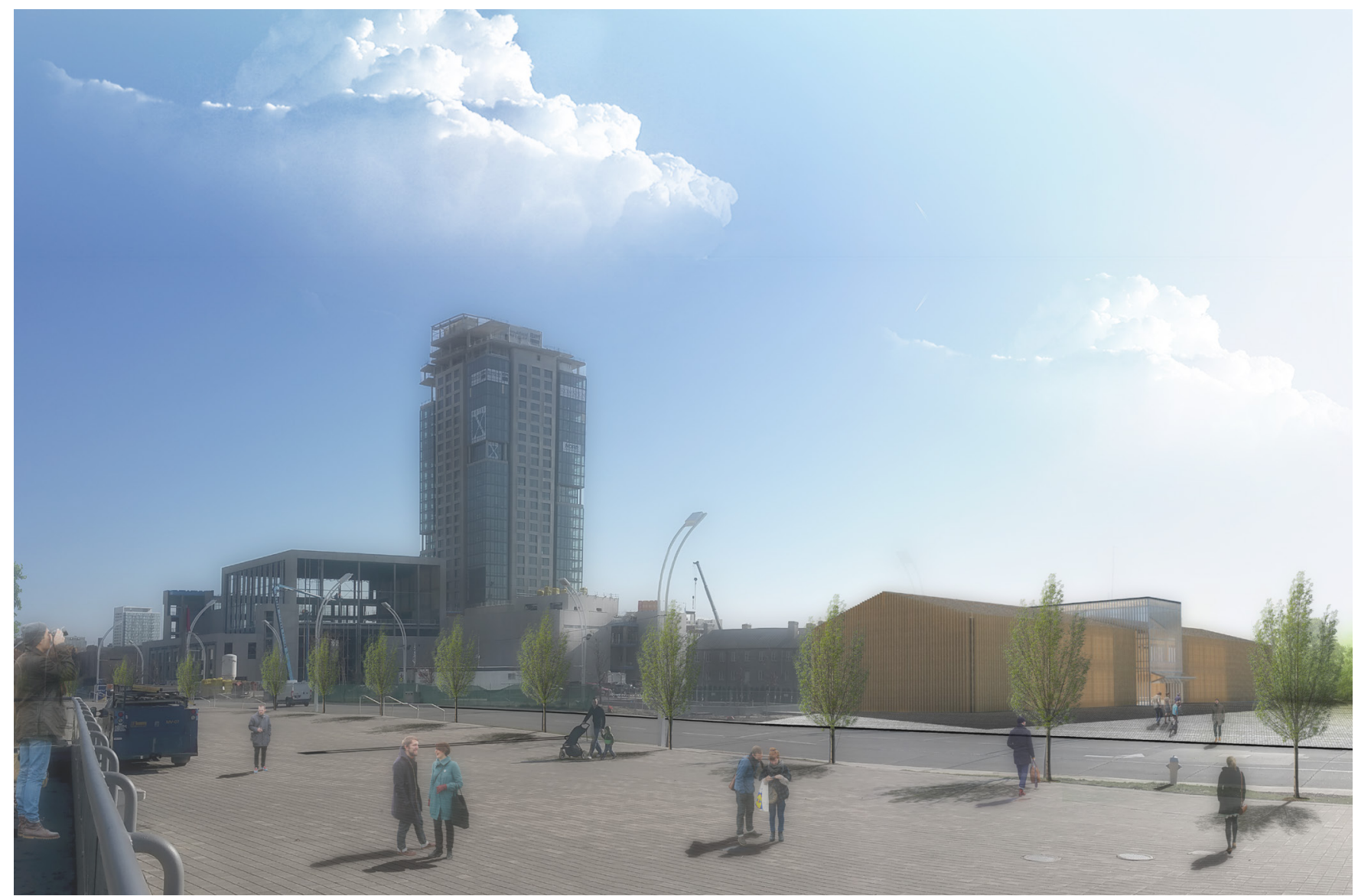

Fig. 36: View of Stanley Barrack Museum from the northwest corner of the Enercare Centre

\subsection{The Design}

\section{Stanley Barrack Museum}

\section{The Site}

Stanley Barrack Museum will be located on the western section of Stanley Barracks, over the ruins of the Privates' Barracks No. 2, the Canteen, and the Barrack Masters' Store. The ruins of Privates' Barrack No. 2, the Canteen, and the Barrack Masters' Store are critical to the design. Revealing and interpreting the archaeological evidence is important to how people lived and used the spaces. Building over the ruins, preserves and protects it from further decay. The ruins become a layer of memory of the past.

The parade square that was removed during the 1950's is reintroduced. The new Parade Square introduces new circulation paths and also a historical one. It becomes a large public space that allows the public to gather and hold events. An additional public space on the south side of the Officers' Barrack is also introduced. The design of the public space would reintroduce the lakeshore back into the design. The design will create new circulation paths connecting Ontario Place with the Stanley Barracks. 


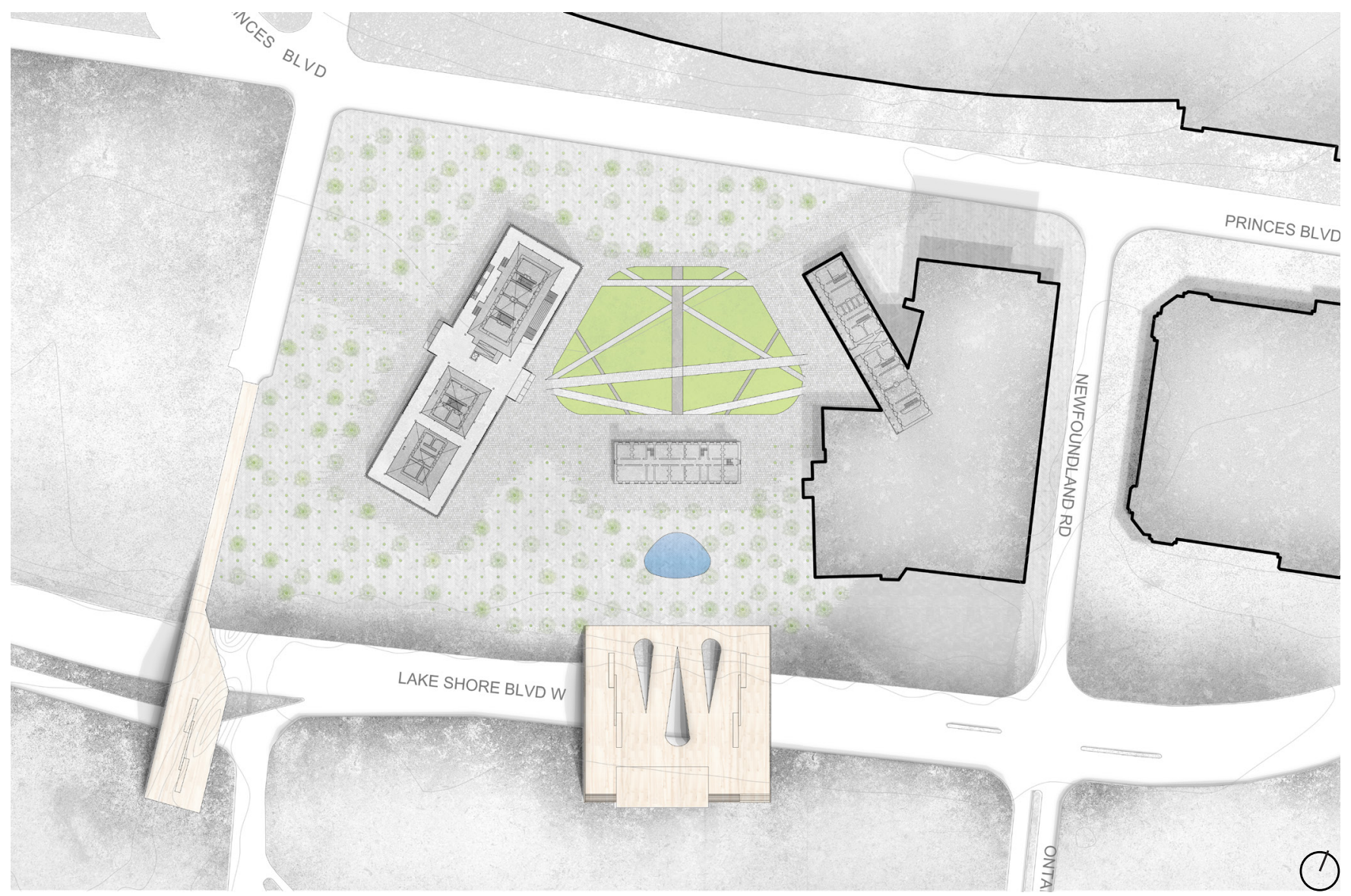

Fig. 37: Site Plan of proposed Stanley Barrack Museum

\section{Ground Floor}

The ground floor reintroduces circulation through the museum similar to the historic eastern gates by opening the building to gain an east and west access. This direct entrance allows visitors to walk through the building and enter the parade square.

Circulation became the main focus to how the palimpsest will be revealed in the design of the museum. Visitors will start from the ground floor, which is the contemporary layer. It was important to show how people would start and end as they walk around the space. This layer is were we exist today, and how people will enter the palimpsest.

As visitors enter the main entryway, there is an option for visitors to view the ruins from above, by viewing it as an archaeological site. The observation walkway surrounds the ruins creating a perimeter where visitors can view the archaeological site from all directions. By viewing the ruins of the buildings from above, visitors can observe, imagine and interoperate the ruins of how they might have existed in the past. 

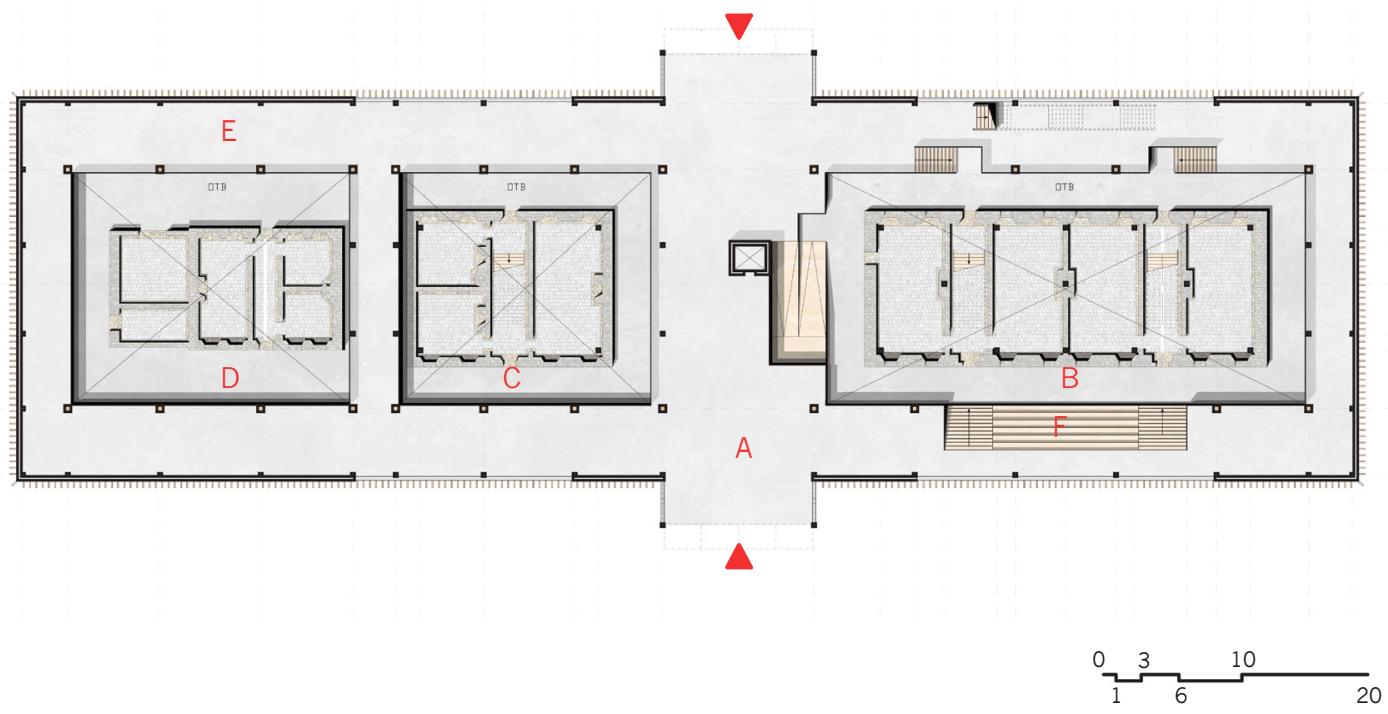

○

\section{A Lobby}

B Officer Barrack No.2 Ruins

C Canteen Ruins

D Master Storage Ruins

E Observation Walkway

F Presentation/ Lounge Seating

Ground Floor

Fig. 38: Ground Floor Plan

The narrative of the site is established as visitors enter the site. The building is divided, informally, into 4 sections; each section is identified by a ruin. The first section is the Privates' Barrack No. 2, second the Canteen, and third the Barrack Masters' Store. The forth section is the entryway between the Privates' Barracks No. 2 and the Canteen. To access the third floor stairs are located behind the ruins.

The first section, the section with the Privates' Barrack No. 2, is where the vertical circulation is located. Visitors are able to transition down through different sets of stairs and ramps to the historic level. The stairs are position in front and behind the ruins as if visitors are approaching the ruin buildings from the front and back doors. 


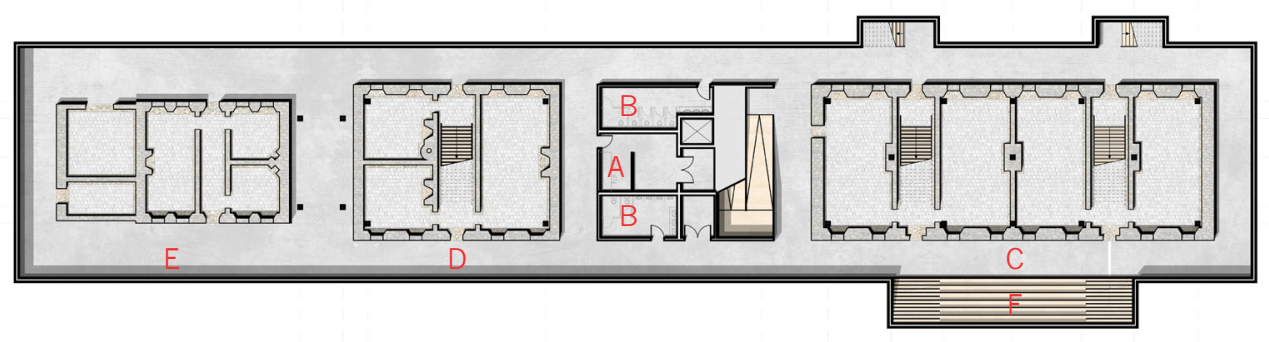

A Administration Office

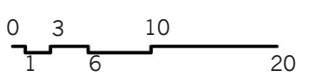

B Washroom

C Officer Barrack No. 2 Ruins

D Canteen Ruins

E Master Storage Ruins

F Presentation/ Lounge Seating

Lower Level

Fig. 39: Lower Level Plan

\section{Lower Level}

The lower level of the museum exposes the ruins, leaving them in their found condition as an archaeological site. The lower level represents the historic level where the remains of ruins and artifact are located. Visitors are encouraged to walk down the stairs to step on to the original surface of the barrack buildings. Exposing the ruins in their found condition preserves them from further decay; it also allows visitors a rare opportunity to interact with the ruins. Visitors can explore the ruins uncovering stories and experiences of how soldier once lived.

The lower level is the only level that features artifacts that are related to the site. Objects and artifacts will be exhibited in the same spaces that they were found. 


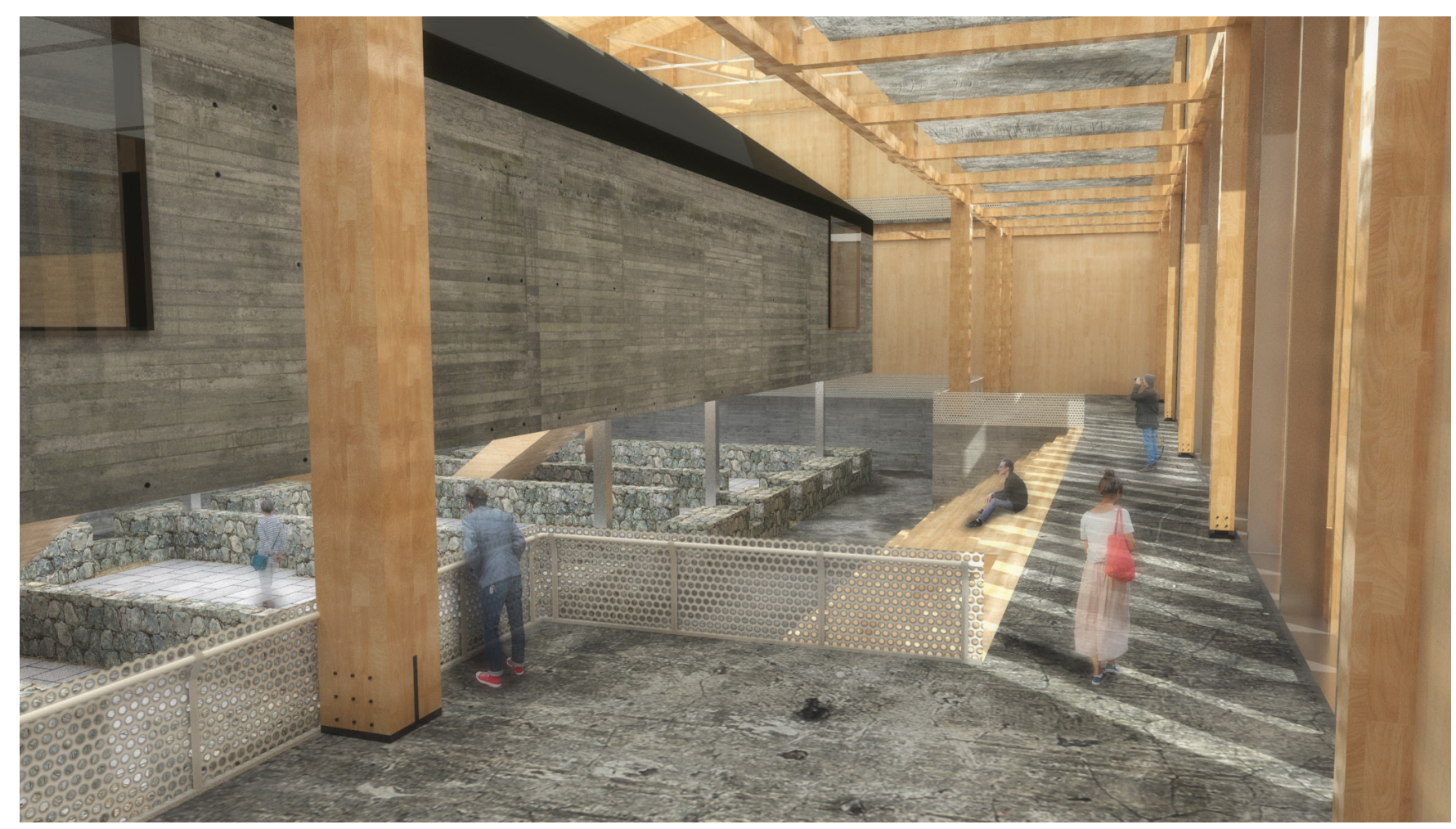

Fig. 40: Interior view of ground floor main seating space and the second floor concrete volume over the ruins of Privates' Barrack No. 2

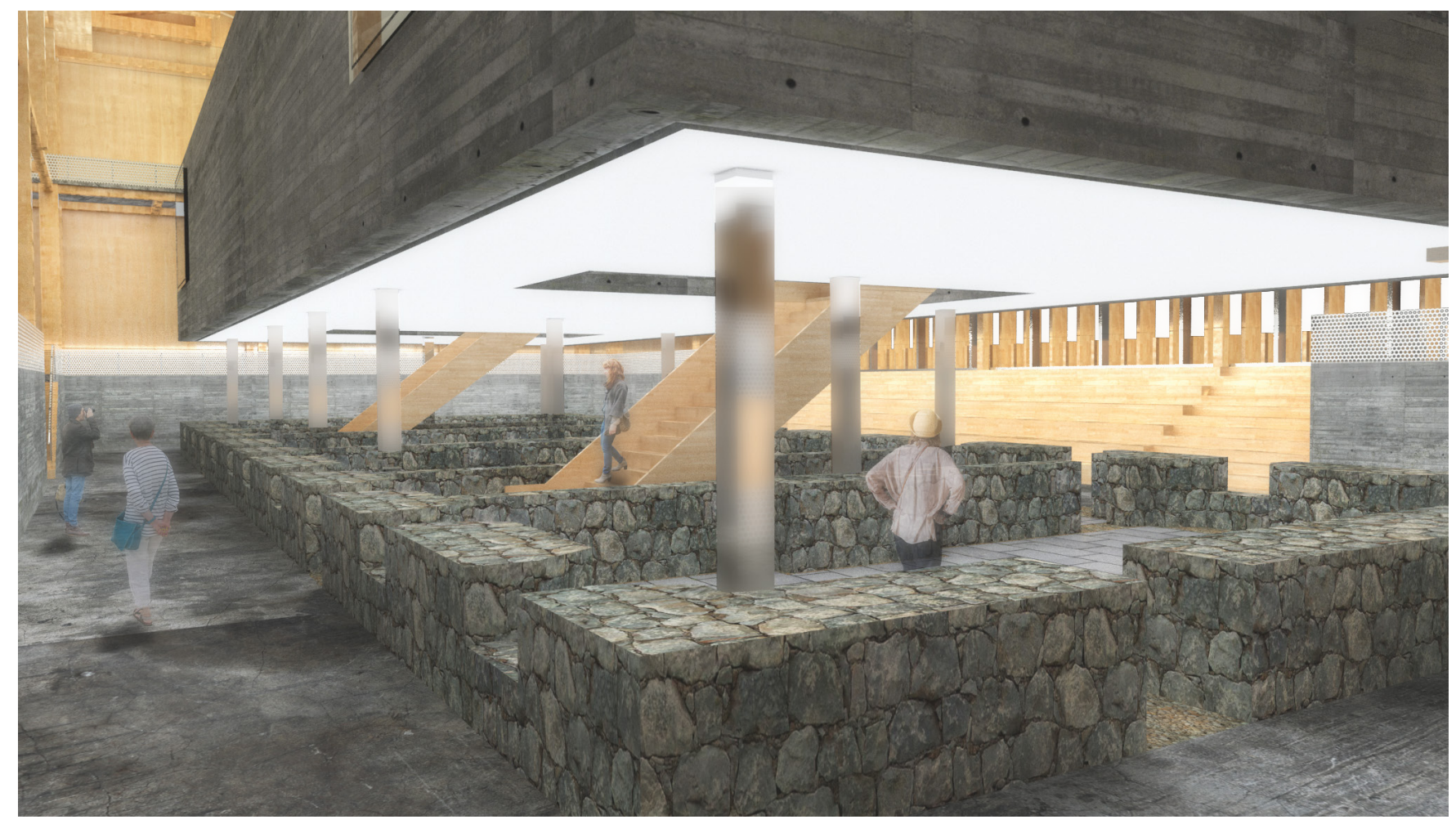

Fig. 41: Interior view of the lower level looking into the ruins and stairs leading to second floor 


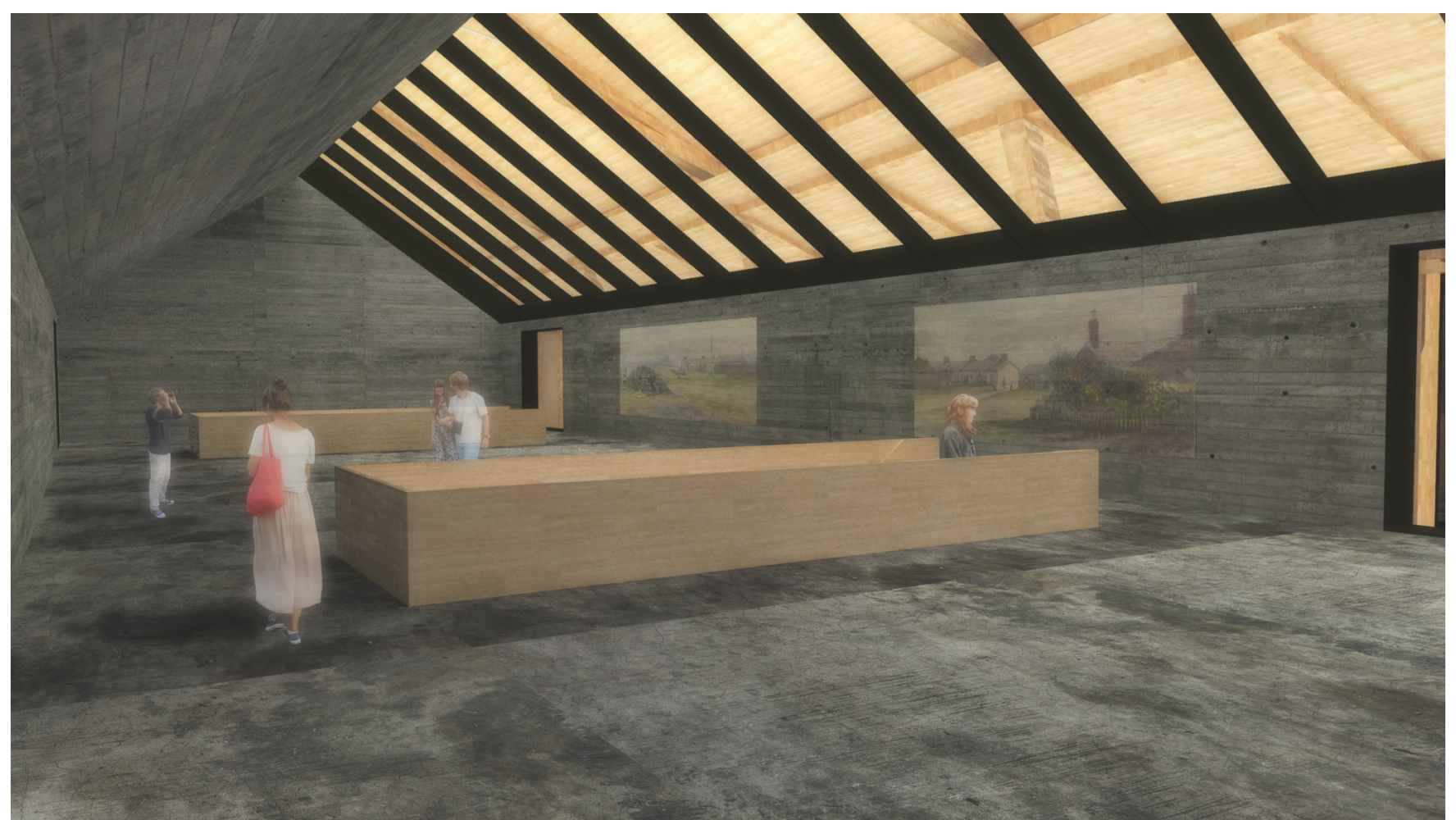

Fig. 42: Interior view of the second floor exhibition and flex space

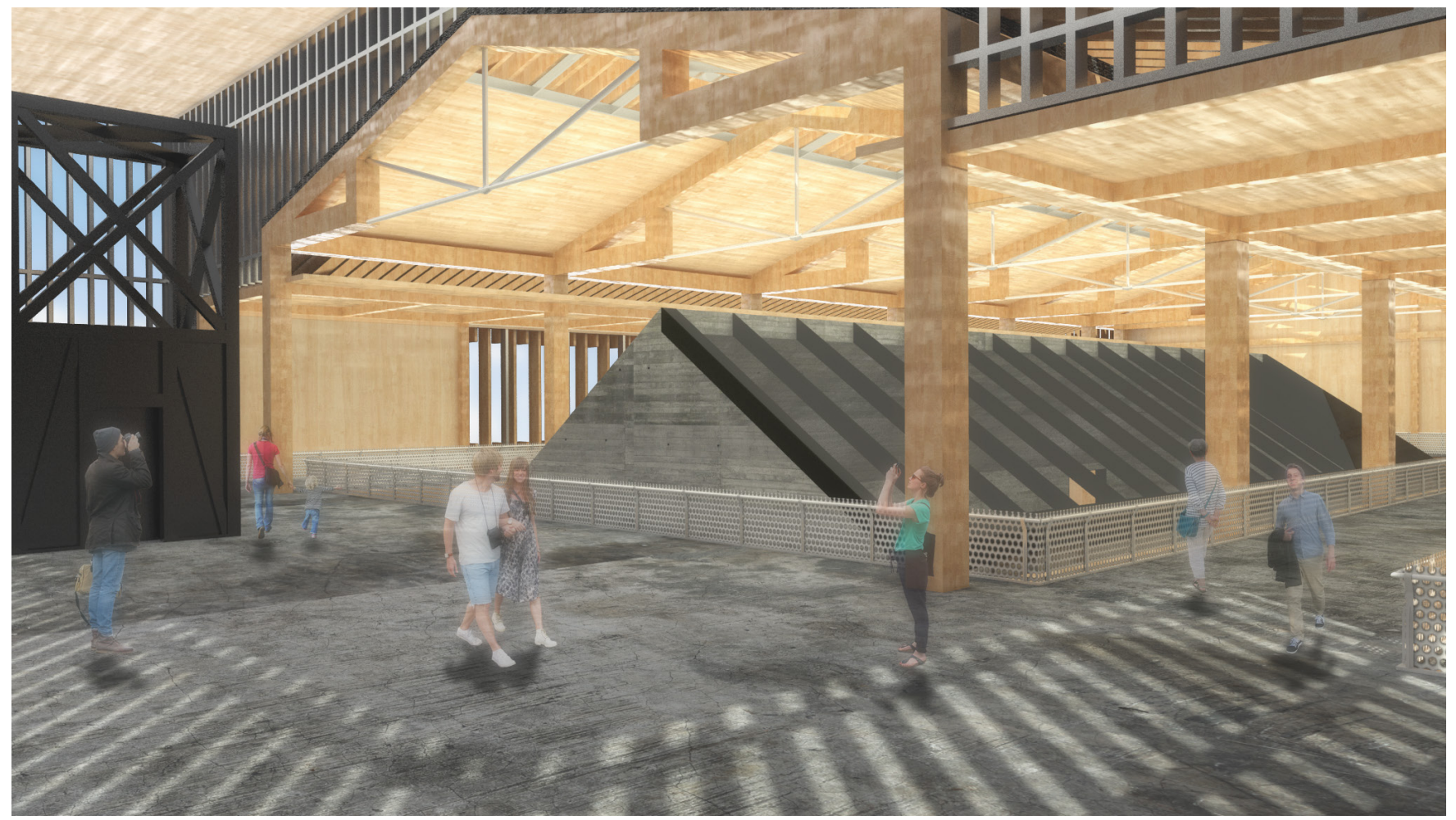

Fig. 43: Interior view of the third floor interpretive space 

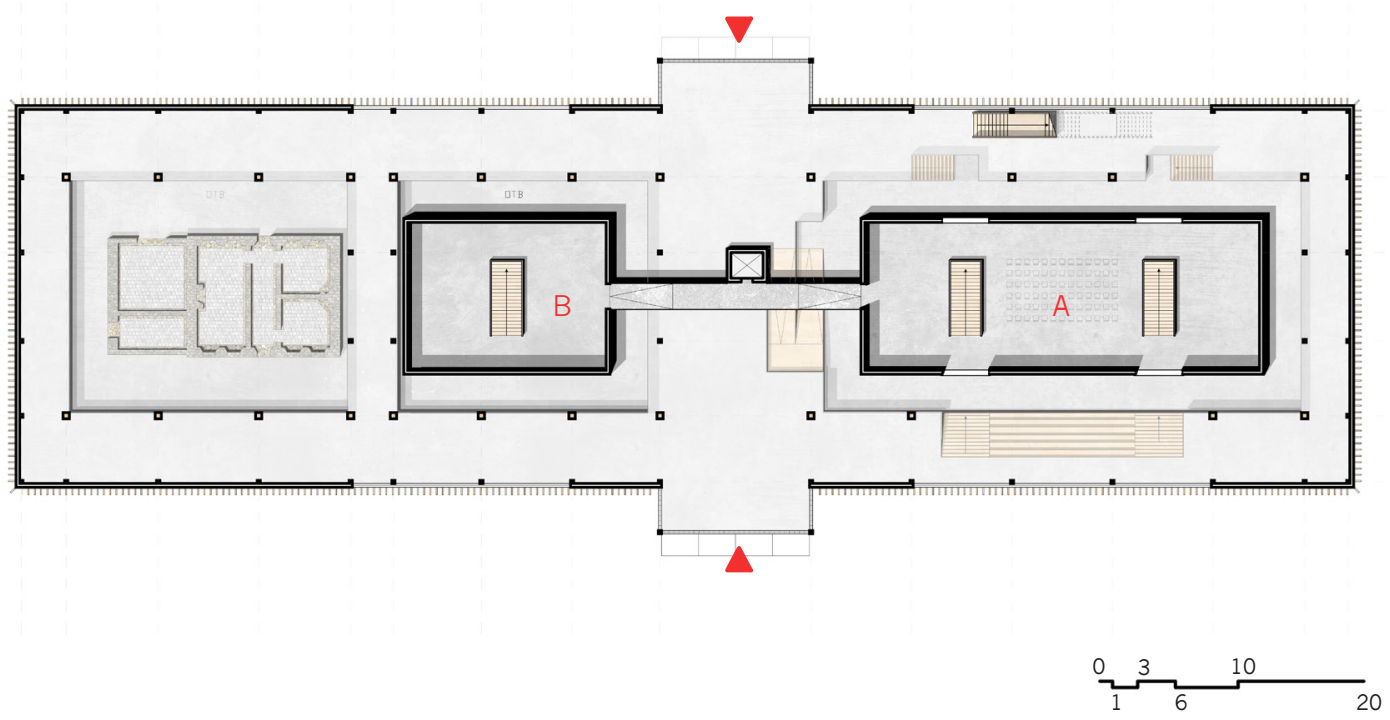

A Exhibition/ Flexible Space B Exhibition/ Flexible Space

\section{Second Floor}

Second Floor

To access the second floor visitors are to go through sets of stairs that are located within the ruins on the lower level. Stairs are only located within the Privates' Barracks No. 2 and the Canteen ruins. The locations of the stairs are at the original locations where stairs were designed into the buildings. It was important to reinterpret the vertical circulation of the barrack buildings, to allow visitors to experience how solider moved within the space. The design draws on the experience and meaning of the space to continue the narrative of each of the buildings that once stood at Stanley Barracks.

The stairs lead visitors to the second floor, which are concrete volumes over the Privates' Barracks No. 2 and the Canteen ruins. The volume traces over the outer wall of the ruins as an abstract recreation of the barracks that stood on the site, in height and mass without restoring its original design. The volume is meant to serve as a mnemonic device to recall experiences and memories of the space. The use of concrete reflected the solid stone structure it once was. The idea was to not recreate or replicate the barrack buildings but allow visitors to understand and interoperate the form, style of the time and importance of the buildings.

The concrete volume would be supported by a steel structure that gives the volume the allusion that it is hovering or floating over the space. 

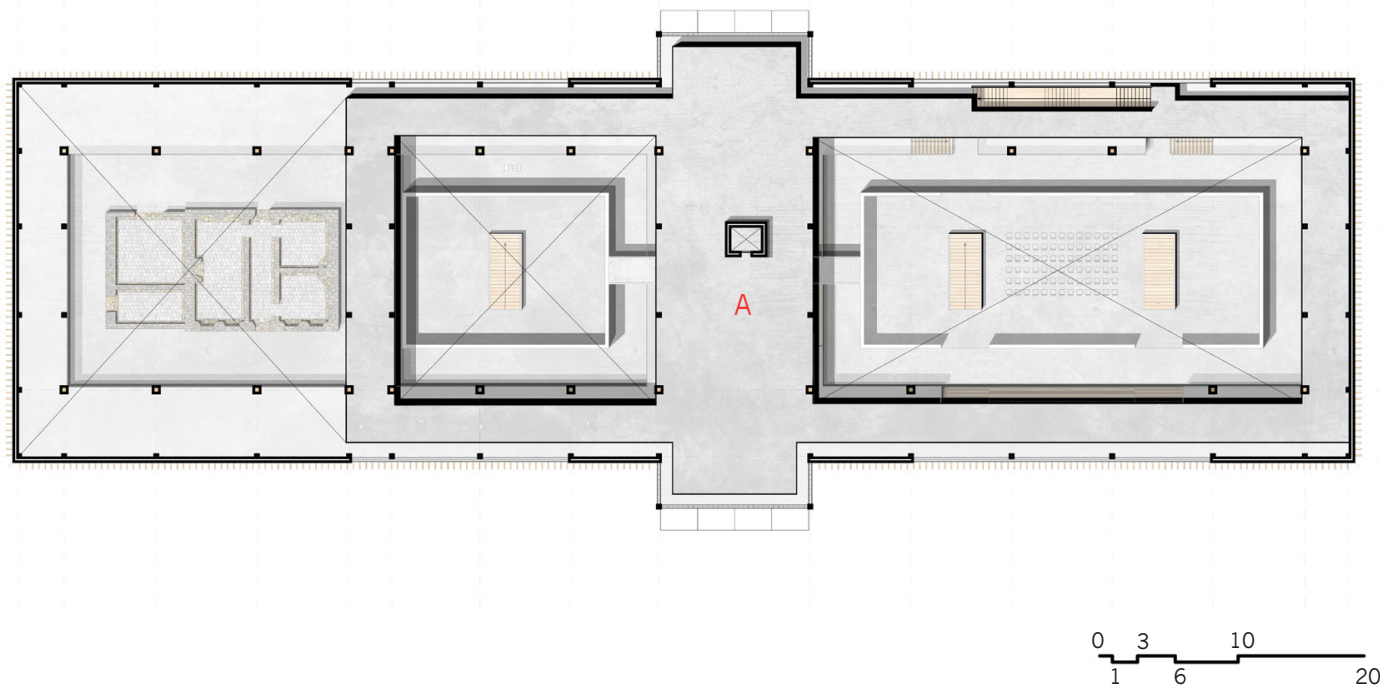

The volumes also have openings from the side and above to allow visitors to view inside the space. This allows visitors to gain another perspective of the space.

On the second floor, within the volume are additional exhibition spaces that can transform into a flexible gathering space for meetings or events.

\section{Third Floor}

The third floor can be accessed though the first section, where Privates' Barrack No.2 is located. Stairs that are located at the back of the volume leads visitors to the third floor. There is also an accessible elevator that can lead visitors to the second and third floor as visitors enter the museum.

The third floor is the interpretive level, where visitors are able to reflect, observe and understand the whole site context. Similar to the ground floor, the third floor is an observation walkway that allows visitors a different perspective of the site from above. Visitors are encouraged to walk around each volume and to look inside. This changes the experience and view of the historical layers differently and constantly reinterpreting the volumes along with the ruins as they would around. 


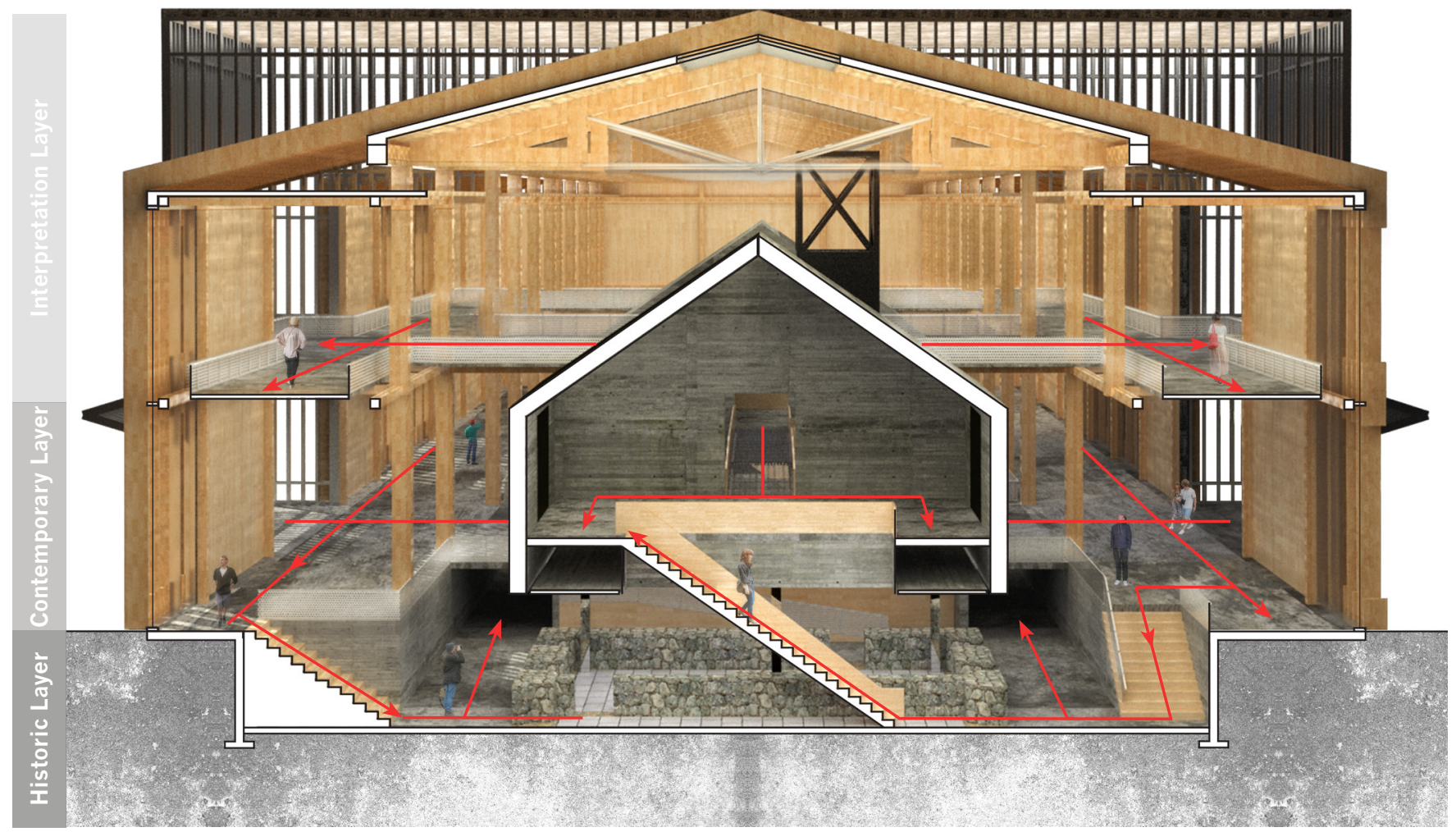

Fig. 46: Diagram of building section in three temporal layers, contemporary, historical and interpretive layers

\section{Circulation Through Temporal Layers}

The design of the museum focused on three different temporal layers that represented the palimpsest that exist. The ground floor is the contemporary layer, where we are currently at and how visitors enter the building. It is also the observation level through the lens of the present. The historic layer is below ground, at the same level where the 19th century ruins and foundations are located. This layer exposes the ruins in their found condition and preserves it as a layer of memory of the buildings that existed. And the third floor is about interpretation, where visitors can constantly reinterpret and understand the different layers, and meaning that exist today and into the future. The interpretation level is meant to be free, to allow a changing narrative of the site.

The vertical circulation becomes important to the design. This is how visitors are able to travel through and explore the different temporal layers. As visitors travel from one layer to the next, the narrative changes and so does the experience of the space. As visitors move below and above ground, exploring the traces from all direction changes the narrative and the interpretation of the site bridging the past, present and future. The military theme changes from one level to the next, revealing to the visitors the stratified layers that are present on the site. 


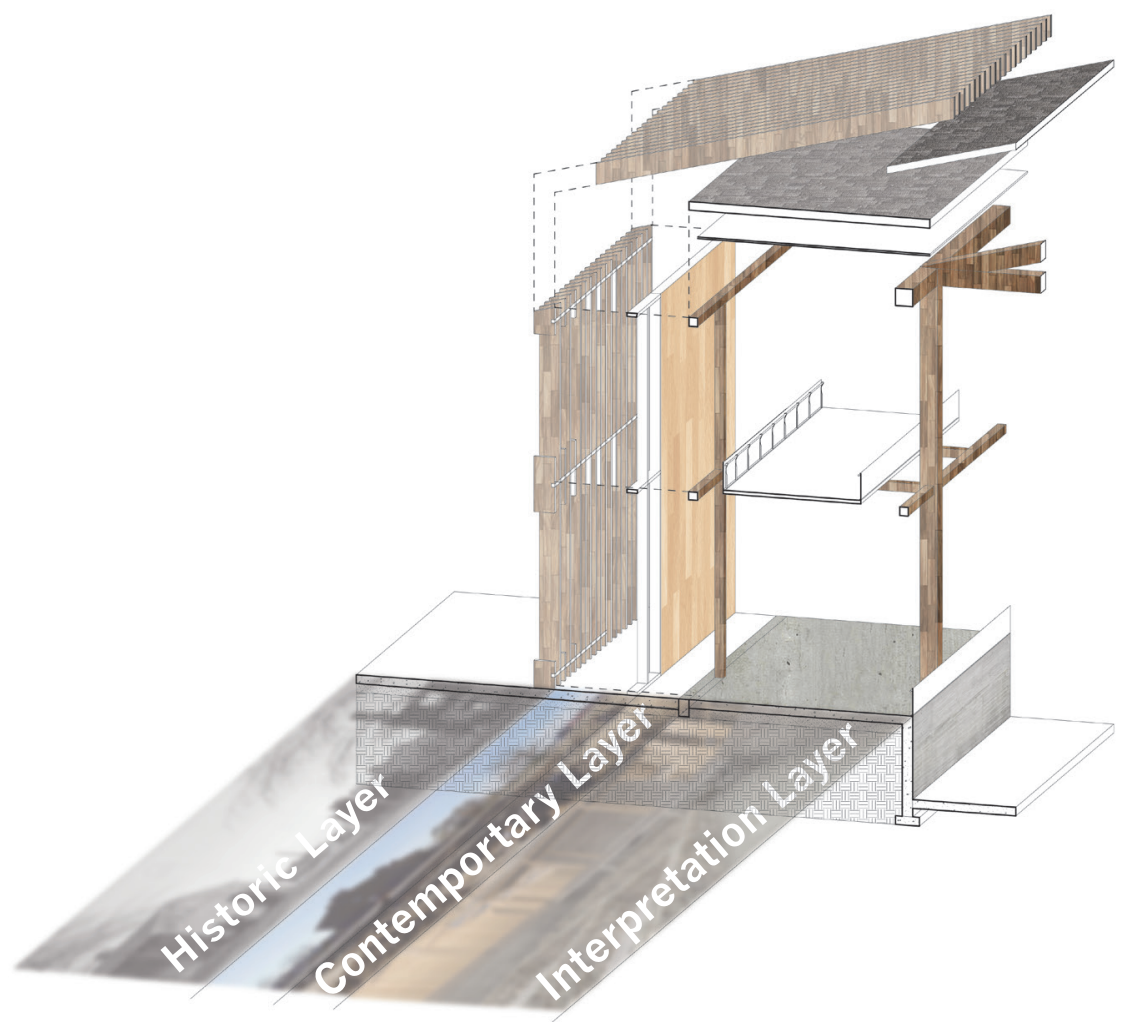

Fig. 47: Exploded axonometric of wall section, detailing the facade construction and the three temporal layers, contemporary, historical and interpretive layers

Fig. 48: (bottom left) Detail section model detailing the construction of the facade construction

Fig. 49: (bottom right) Detail section mode detailing the exterior construction and pattern of the facade
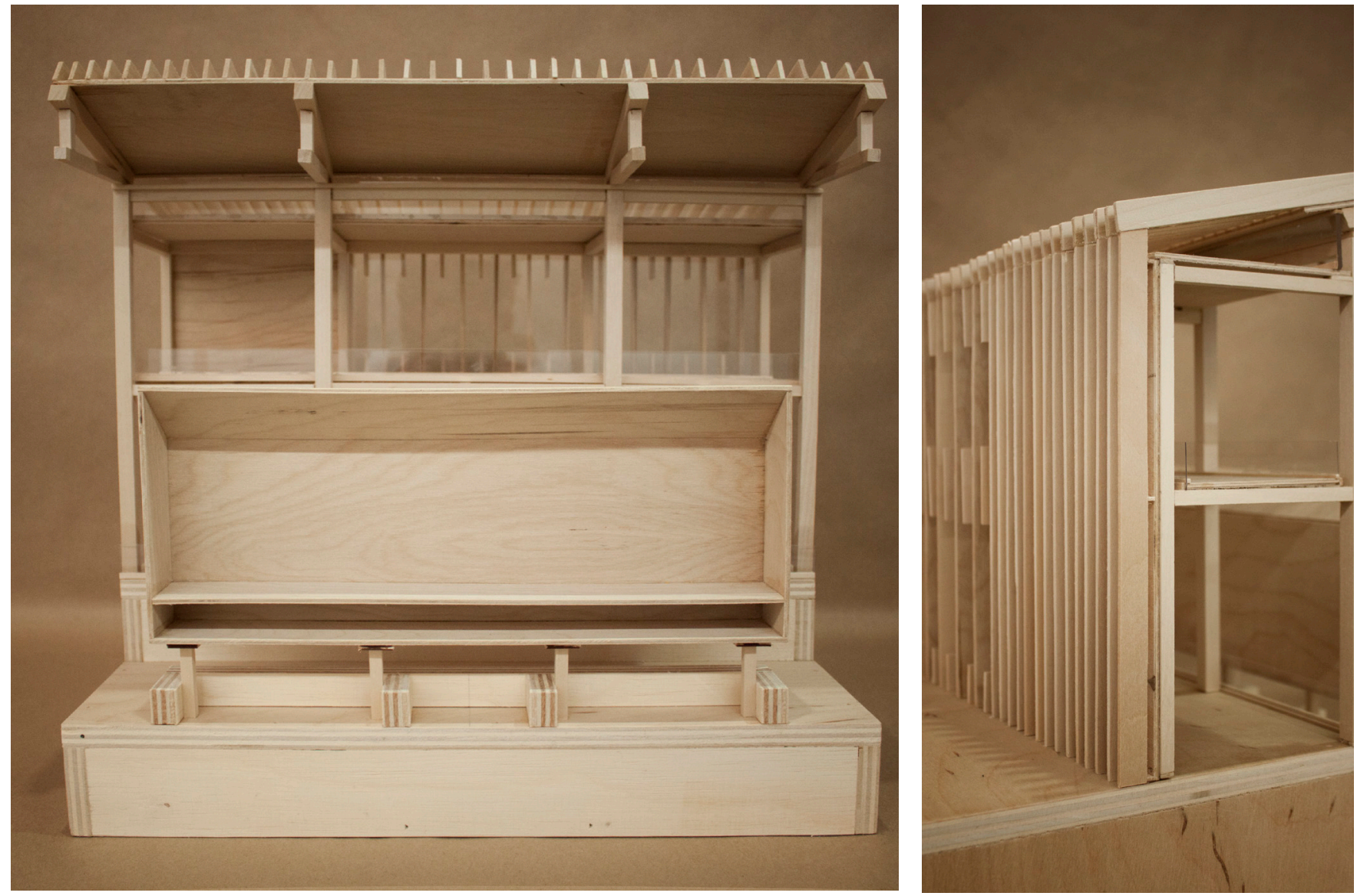


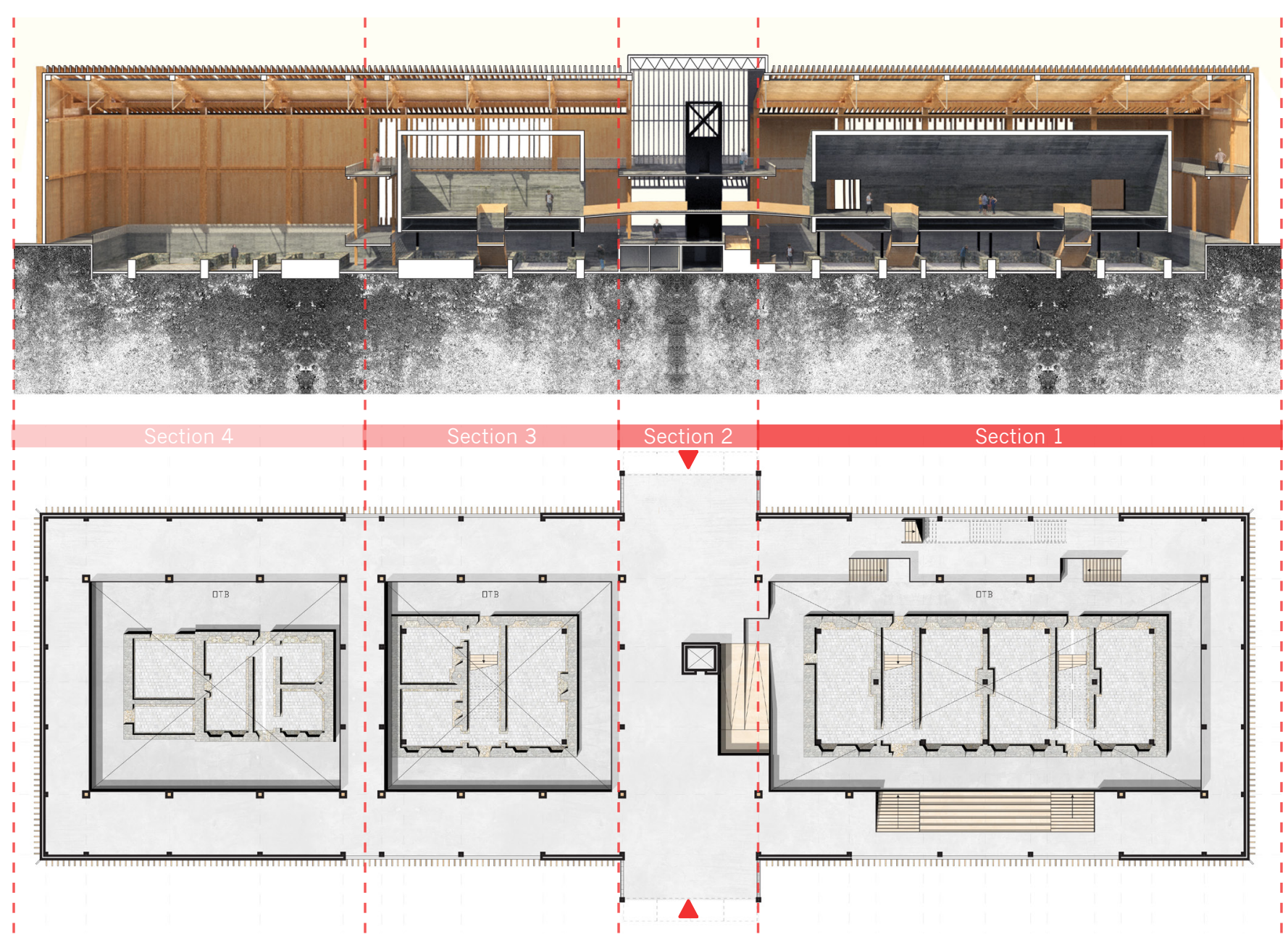

Fig. 50: Diagram of plan and section of Stanley Barracks Museum divided into four different sections

\section{Four Sections of Stanley Barrack}

The museum is divided into four sections; each section is identified by each ruin. The first section is the Privates' Barrack No. 2, second the Canteen, and third the Barracks Masters' Store and the forth section is the entryway between the Privates' Barracks No. 2 and the Canteen. The first section, the Privates' Barrack No. 2, is where all vertical circulation is located to access the lower level and third floor are stairs to lead visitors to these spaces.

The first and second section also features large concrete volumes that are located above the ruins. They become mnemonic devices to recall experiences, meanings and memories that existed on the site. The aim of the design was not to recreate the barrack buildings, but to reinterpret them as visitors explore the space.

The third section, the Barracks Masters' Store, was left in its found condition as an archaeological site. This allows visitors to understand how stratification and layering of the site occurred as well as understanding how archaeological investigation works. This also allows for future interoperation and investigation of the site. 


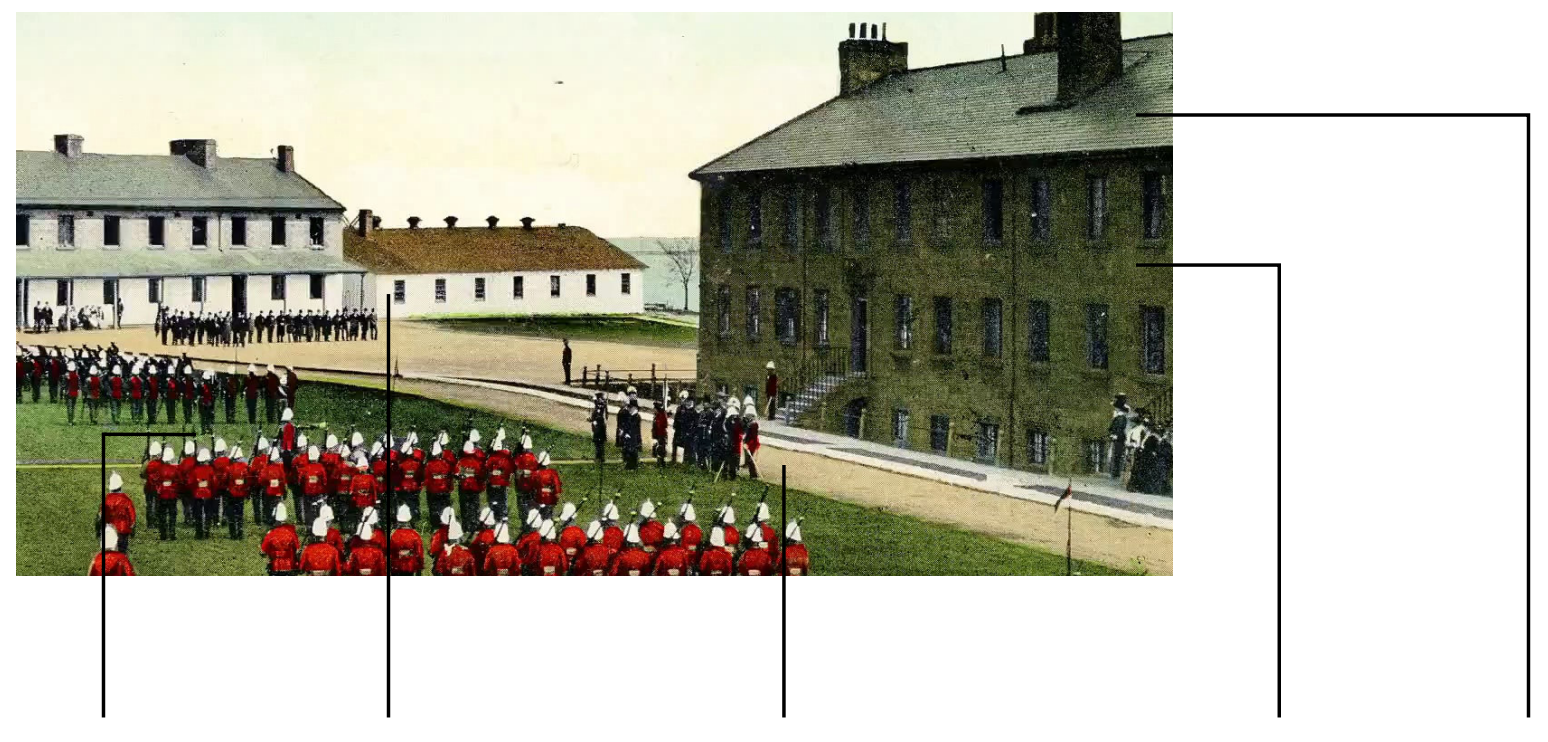

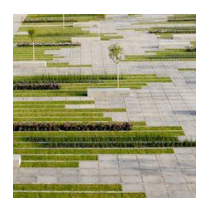

Parade Square

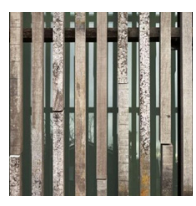

Wood Slates

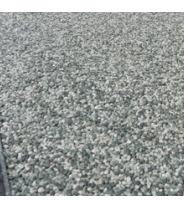

Permeable Surface Paving

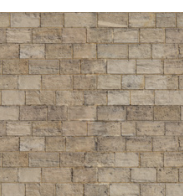

Limestone and Concrete

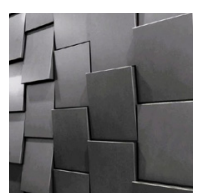

Tin Roof

\section{Material Selection}

Each of the materials that were chosen for the museum makes reference to the design of Stanley Barracks. The glulam timber structure that supports the building for example, is carefully interested into the site that surrounds the ruins. The timber structure does not meet or touch the ruins, but instead is set back to allow the ruins to be free from distractions. The timber interior and structure, provides warmth to the space against the cold concrete and ruins. The fins, wooden interior and timber structure refers back to the materials associated with the past, providing a contemporary interoperation. The ground surface is made of concrete, while railings are perforated steel panels.

The volume is made out of concrete referring back to the stone barrack structure, scale and mass. Steel columns that touch the surface of the historic layer support the volume. It does not touch the ruins itself. The effect of this detail was to hide the moment of connection giving the appearance the volume is floating above the ruins to interoperate the mass and scale of the building.

Frameless glass is pinned lightly to the exterior of the volume where opening are located. It was intended to not just allow visitors to view the interior of the space but also the idea that occupants can look out not disturbed by a framed view.
Fig. 51: Diagram of material selected to be used that draws reference to the historical material used at Stanley Barracks 


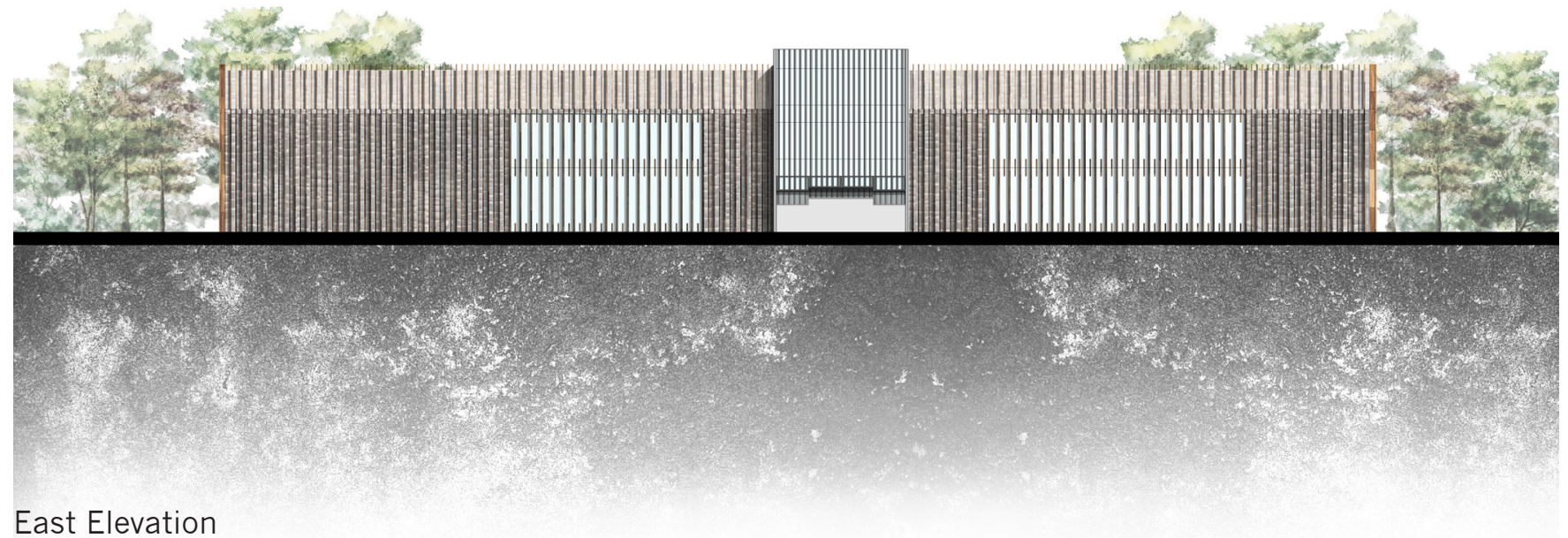

Fig. 52: East elevation of Stanley Barrack Museum

\section{The Process of Designing the Form and Envelope System}

Similar to the different layers of palimpsest that was identified in section, the historic, the contemporary and the interpretative level, the building envelope and façade use the same layers.

The façade featured vertical wooden fins backed with a charred wood surface to contrast with the wooden fins. The wooden fins are the historical layer that refers back to the historical wooden post fence that surrounded Stanley Barracks. The contemporary layer is the barrier, the charred wood and the contemporary construction of the building envelope. While the interpretation layer is the circulation and voids that allows visitors to observe the ruins.

The form of the building is an abstract interpretation of the Barracks that existed on the site. It is a large three story tall pitched roof building that features the wooden fins contrasting against the charred wood surface. Designing using density of the wooden fins distinguished where the windows of the façade will be located. To break up the form, the entrance is highlighted using steel frame construction and glass that contrast with the form, while the structure of the building is a glulam wood frame construction with a trust system to hold up the roof. 


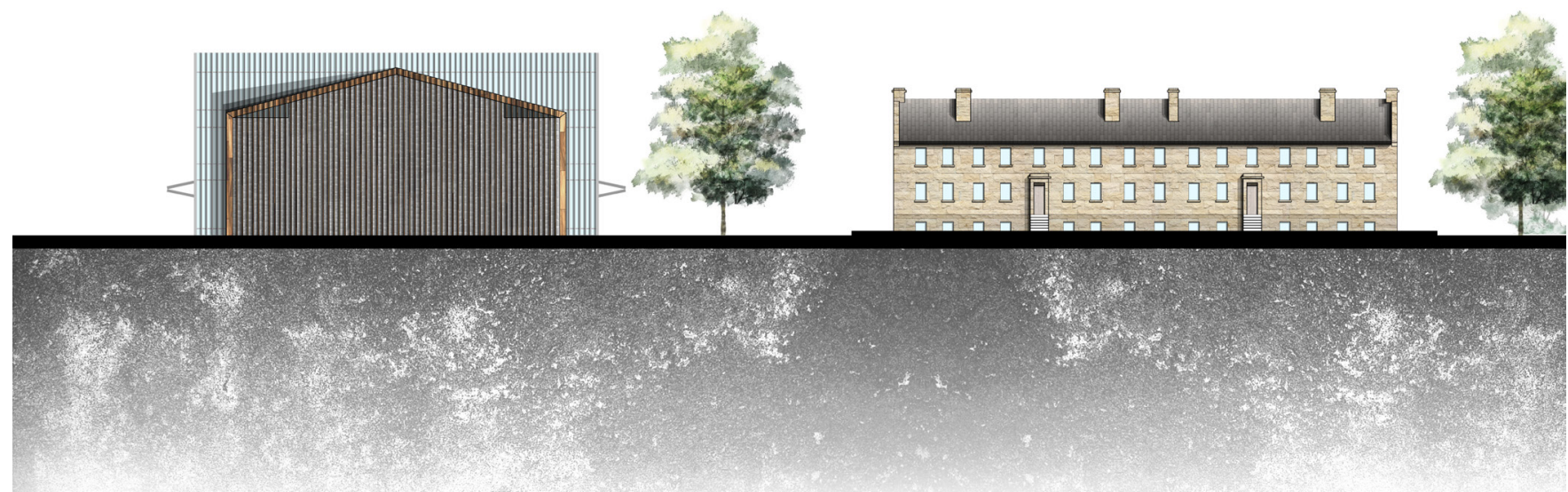

North Elevation

Fig. 53: North elevation of Stanley Barrack

Museum and the Officers' Quarter

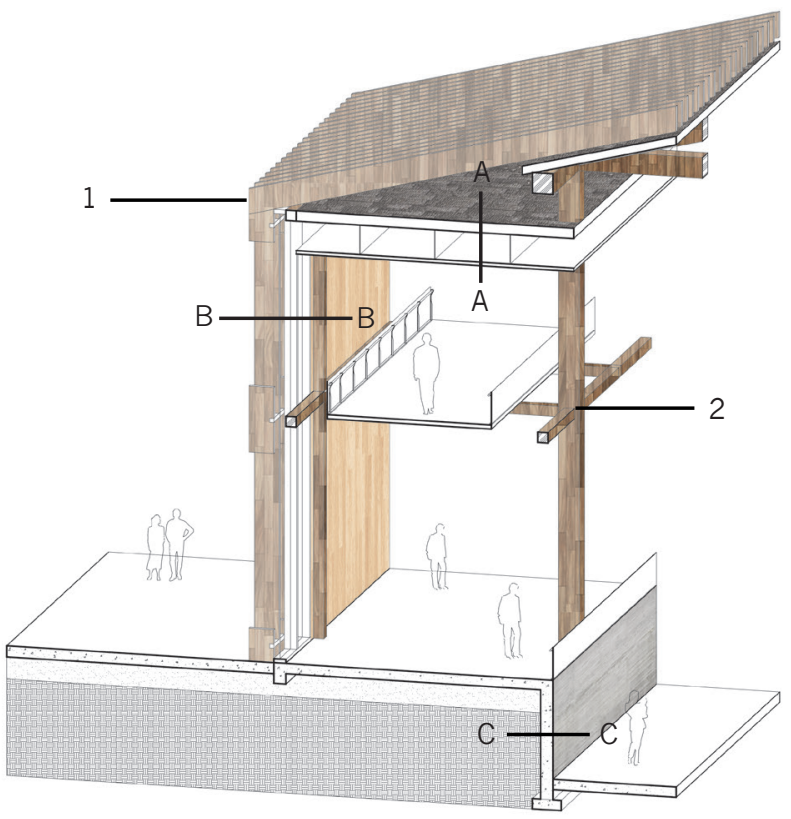

A

Charred Wood Roof Decking 50mm Membrane Base

Built Up Roof

Rigid Insulation $100 \mathrm{~mm}$

Vapour Barrier

Corriageted Roof Decking

$600 \mathrm{~mm}$ Air Space

Drop ceiling, suspended, gypsum interior finish

B

Charred Wood Paneling

Membrane

$100 \mathrm{~mm}$ insulation

Vapour Barrier

C

Membrane

$130 \mathrm{~mm} \cdot 210 \mathrm{~mm}$ rigid Insulation

Vapour Barrier

$300 \mathrm{~mm}$ Reinforced Concrete Foundation

wall

Interior Finish

1

$600 \mathrm{~mm}$ Vertical Wood Panels

Glulam Wood Structure

Fig. 54: Axonometric of wall section 


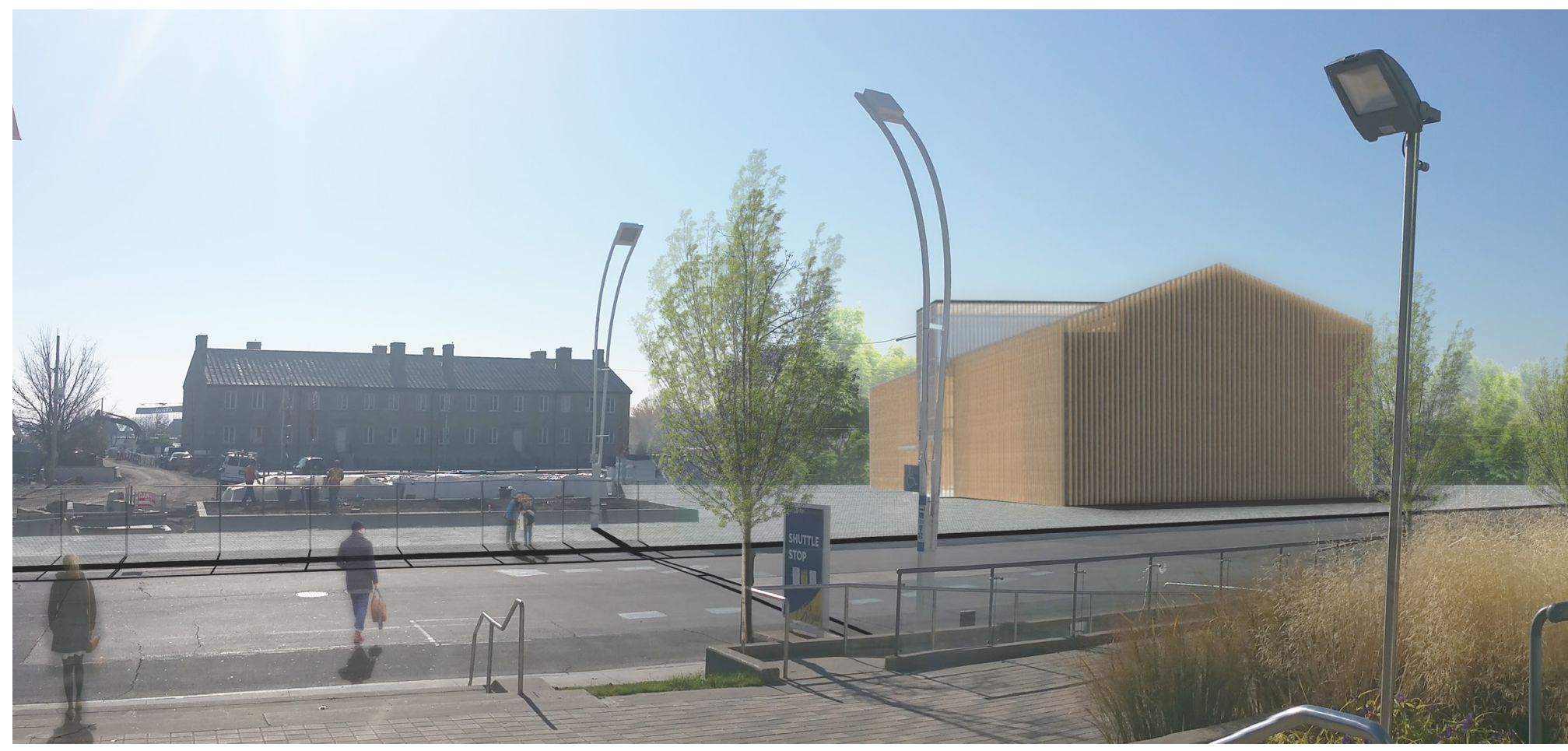

Fig. 55: Exterior view of Stanley Barrack Museum from the northeast corner, across from the Enercare Centre 
Section 4.0

Speculation 


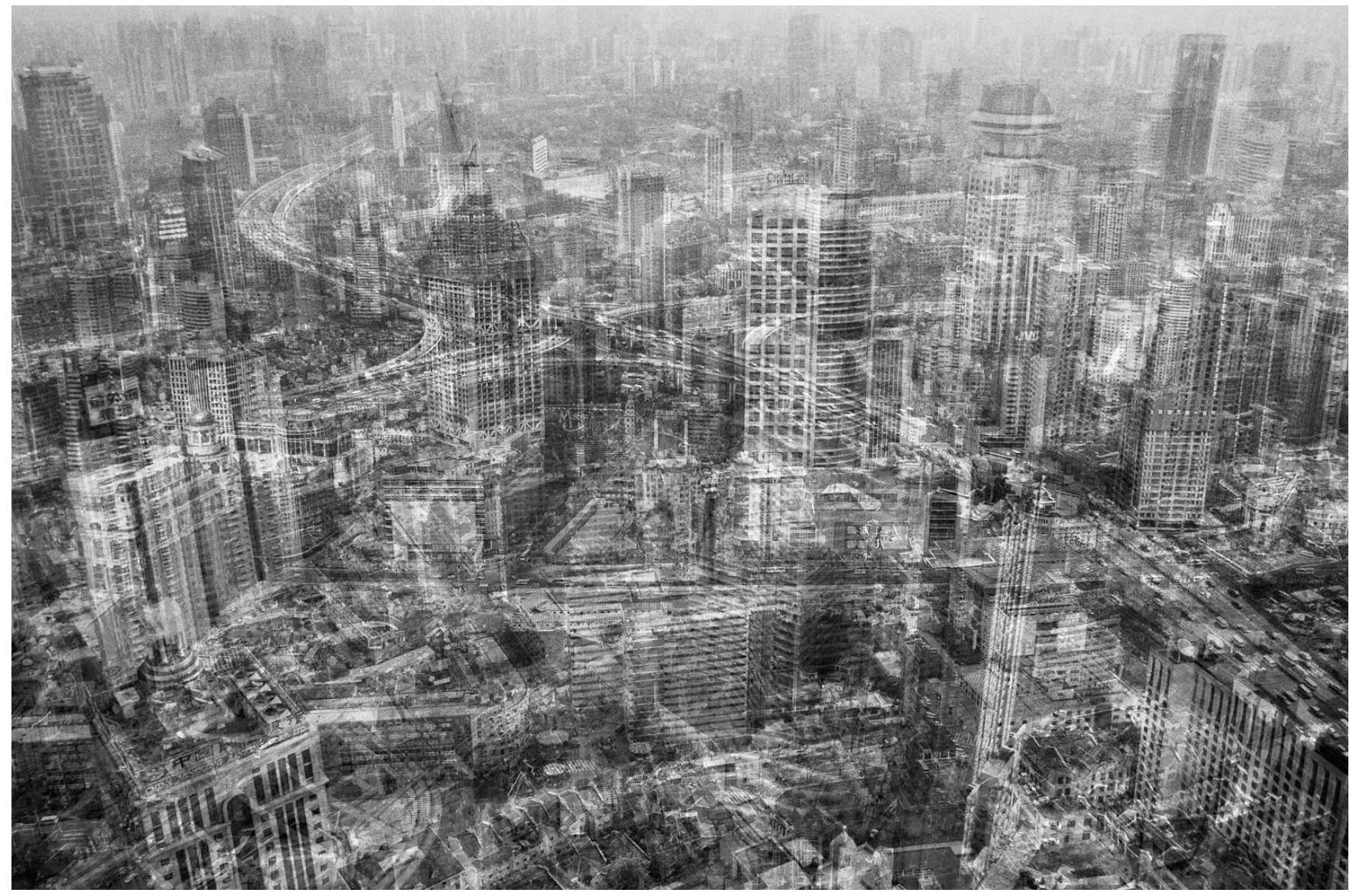

Fig. 1: Netropolis Shanghai 2003-2006 by Michael Naggar is part of an exploration of

the cities will develop in the future. 


\subsection{Speculation}

Preservation in architecture fails to consider the palimpsest. The aim of this thesis is to provide an alternative method to preservation. And how it can be used in architecture by means of designing existing historic buildings to reveal the palimpsest that exists within. However, being mindful of it and considering existing buildings not as time capsules but as palimpsests can add new layers of meaning to architecture.

The concept of palimpsest is a phenomenon that constantly occurs around us as seen throughout this thesis. The erasing of a surface and re-writing on it to leave traces behind can allow for the emergence of patterns that will influence future designs. It is important to understand that building sites are never a clean slate but that multiple layers may exist. Revealing layers of palimpsest can influence the final product as well as the design process itself.

The Museum at Stanley Barracks allows the palimpsest to reveal itself as visitors travel through the building, experiencing and interpreting the layers that exist. As the narrative changes, so does the interoperation of the space, especially as regards to the future. As Stanley Barracks deals with new information and interoperation, the design can be altered, adapted, changed or erased to become part of a palimpsest that will influence future designs.

New interventions can reveal the traces that remain and thereby create a narrative that allows us to explore the relationship between past, present and future. The utilization of the idea of palimpsest can bring depth and meaning to architecture and will avoid the overworked 'solution' of just demolition and removal of existing buildings. 


\section{Section 5.0 Appendix}




\section{Appendix A | Final Drawings}

List of Drawings

Site Plan

Ground Floor

Lower Level

Second Floor

Third Floor

East Elevation

North Elevation

Section A-A

Section $B-B$

Section $C-C$

Section B-B North View 


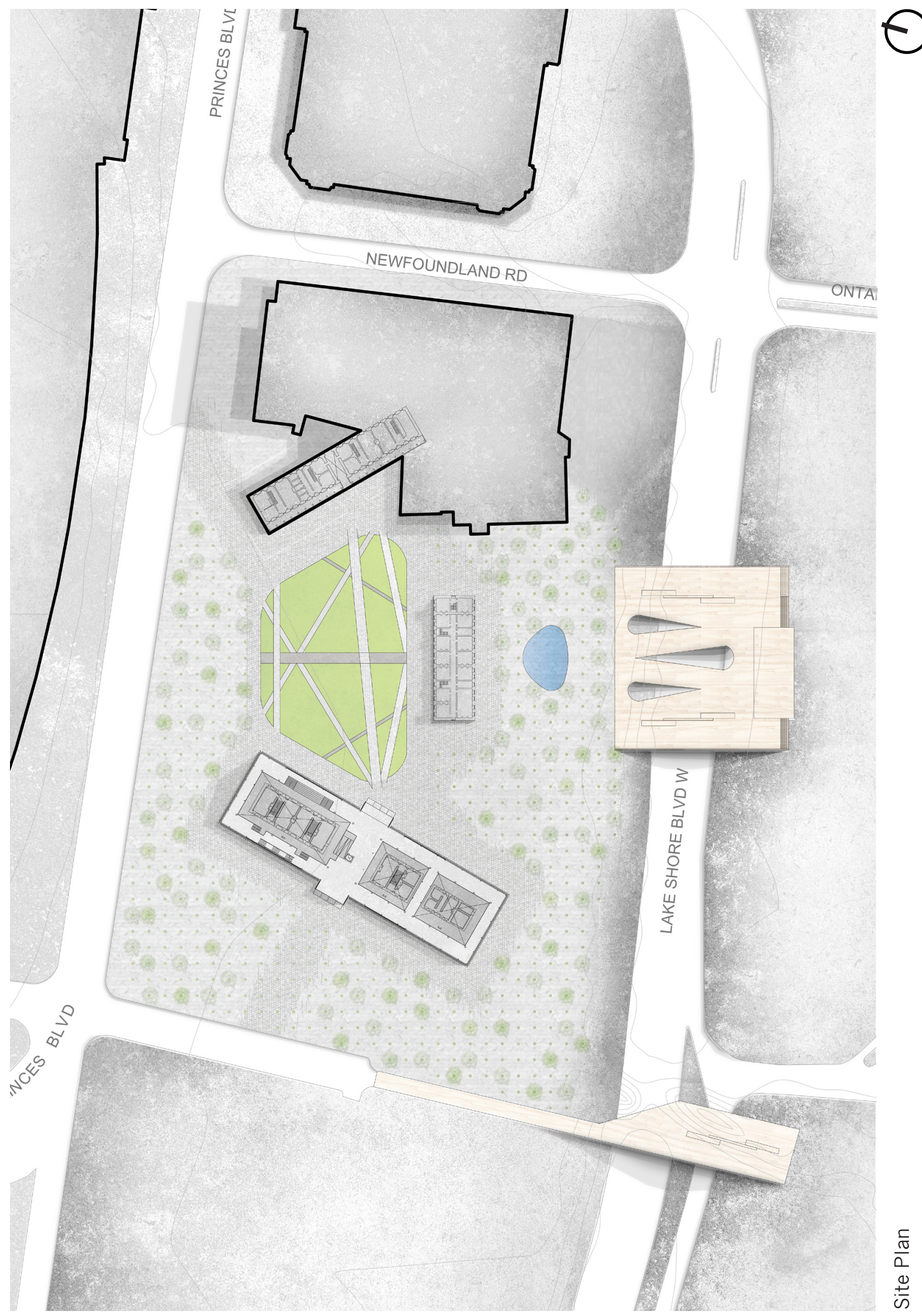


○
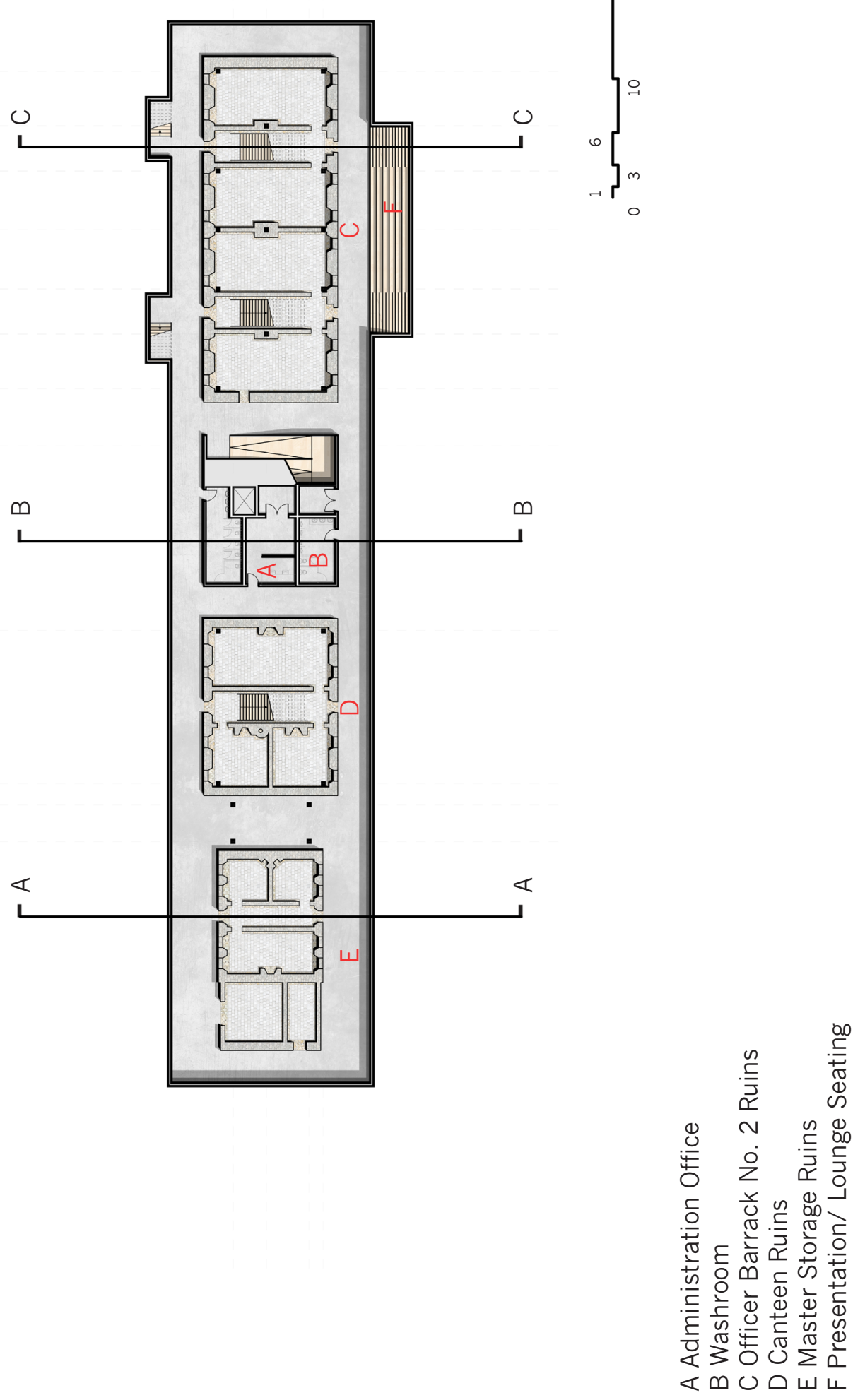


\section{○}

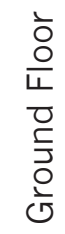
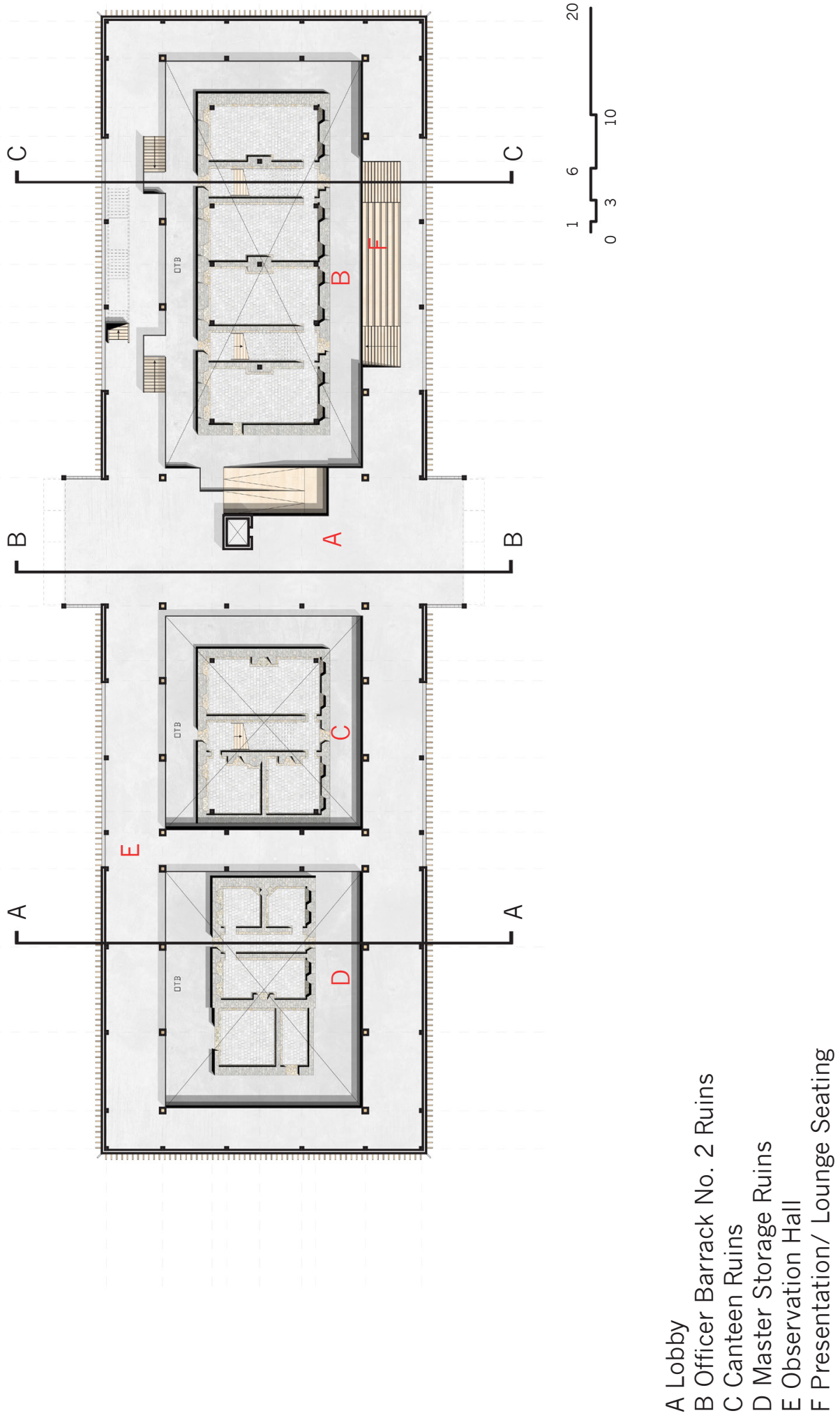
○

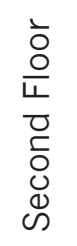

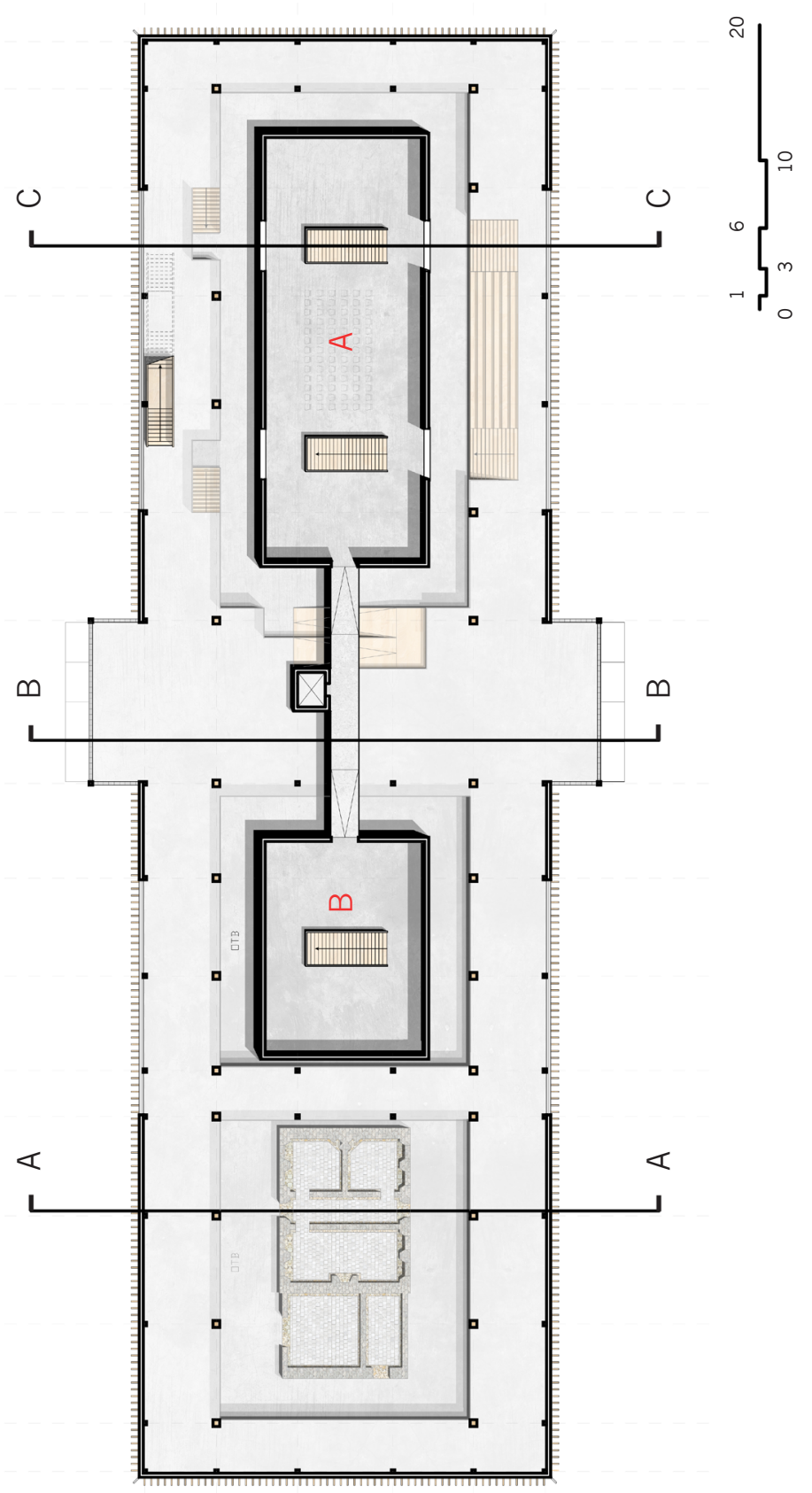

0
0
0
0
0
0
की
की

$\frac{0}{0} \frac{1}{0}$

전

$\frac{\infty}{\square} \frac{0}{\square}$

등등

高

س

$\varangle \infty$ 
0

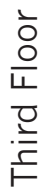

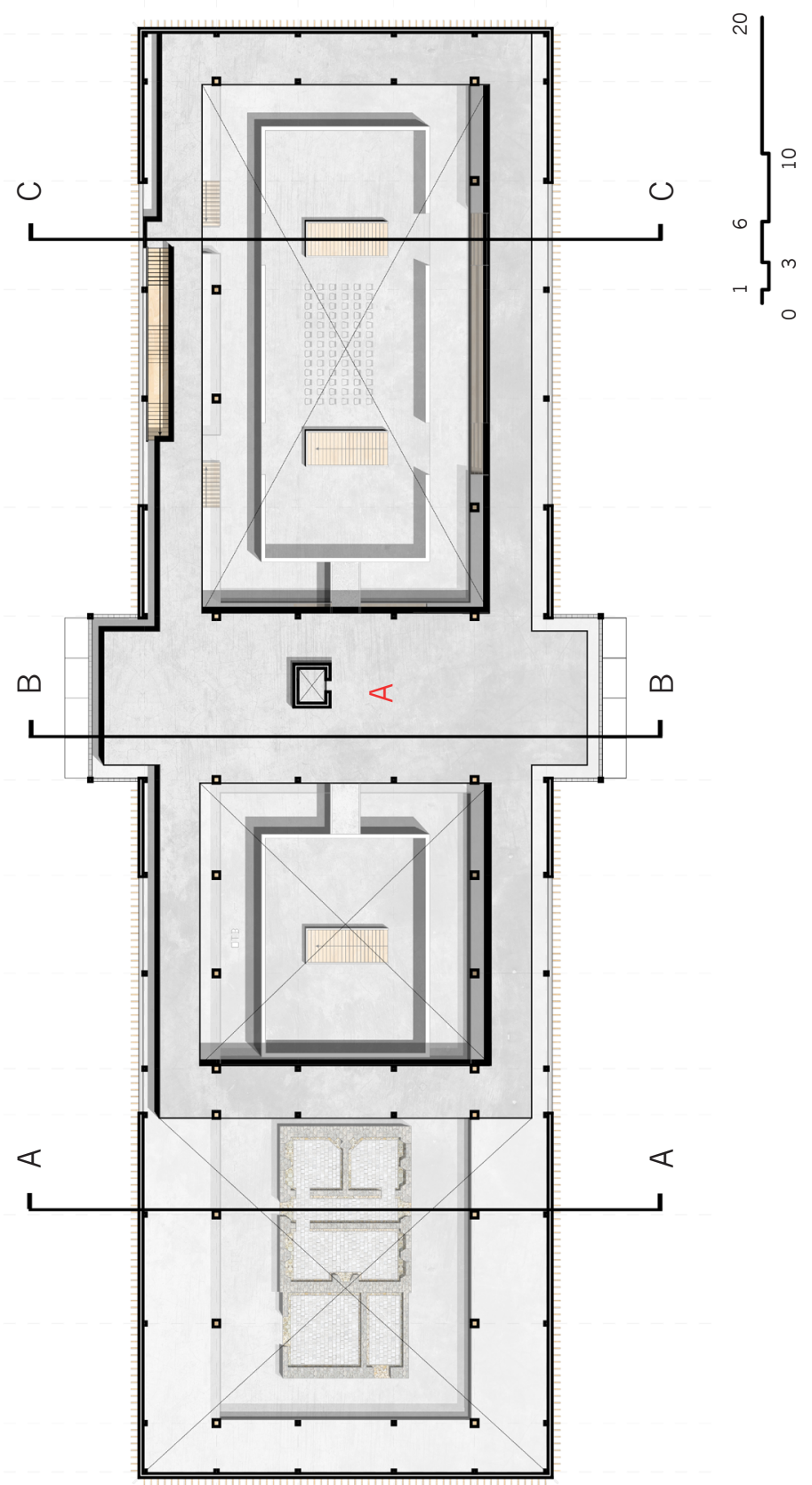

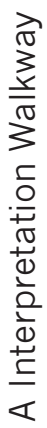




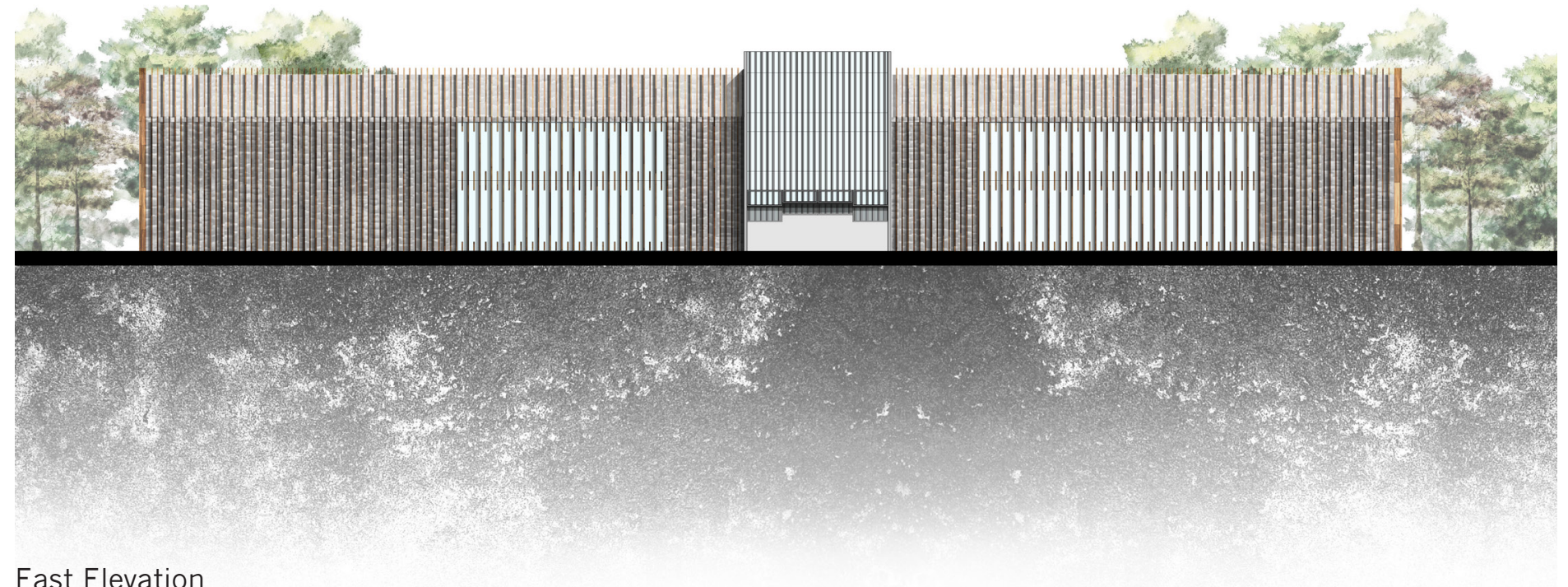




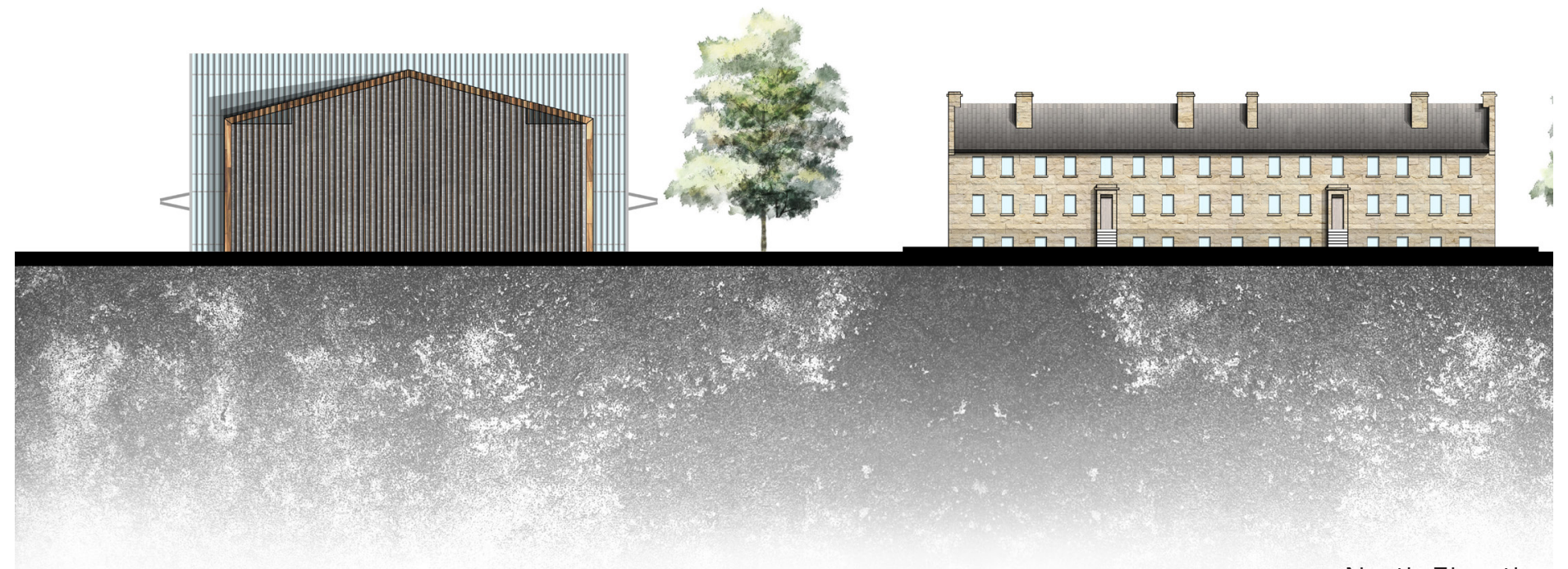

North Elevation 


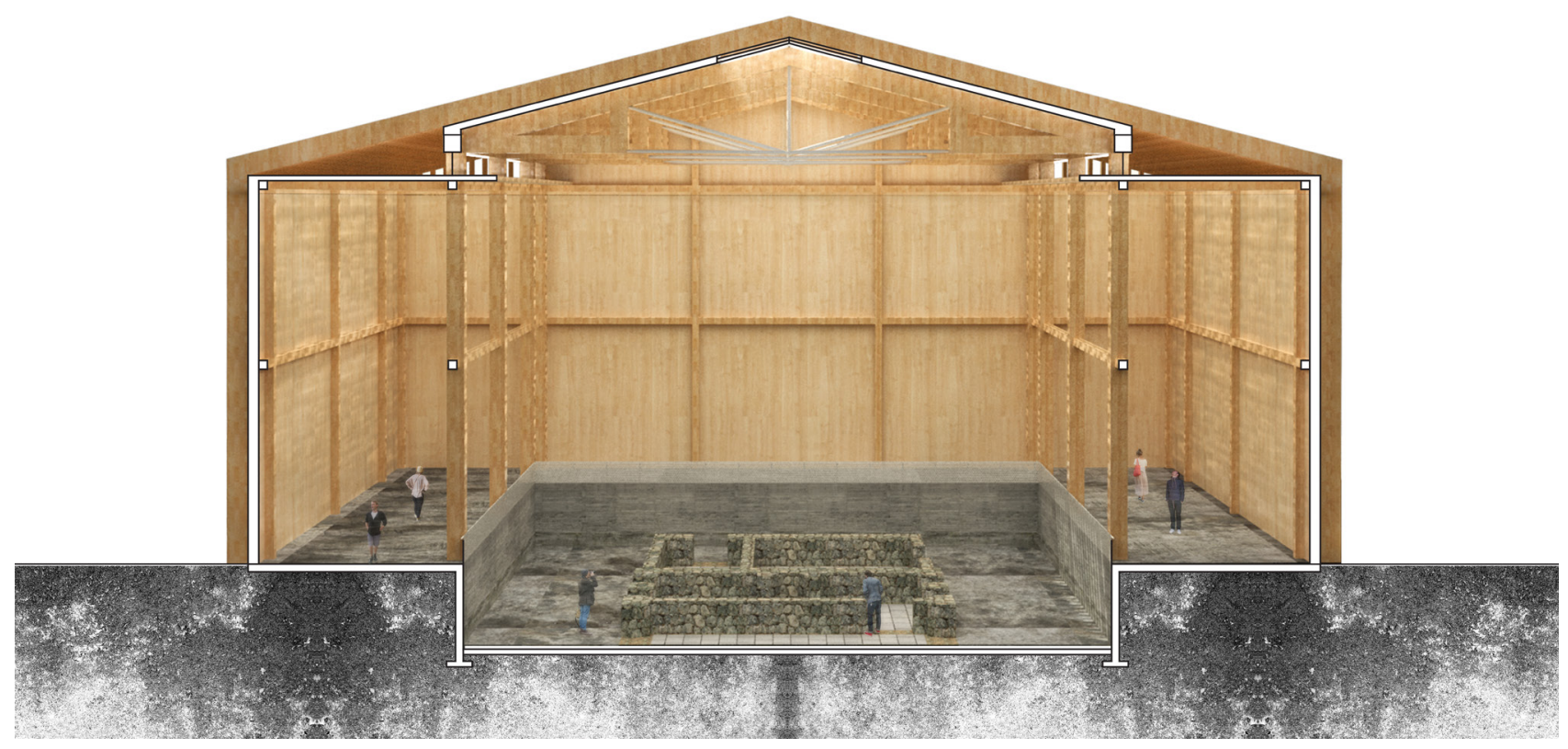

Section A-A

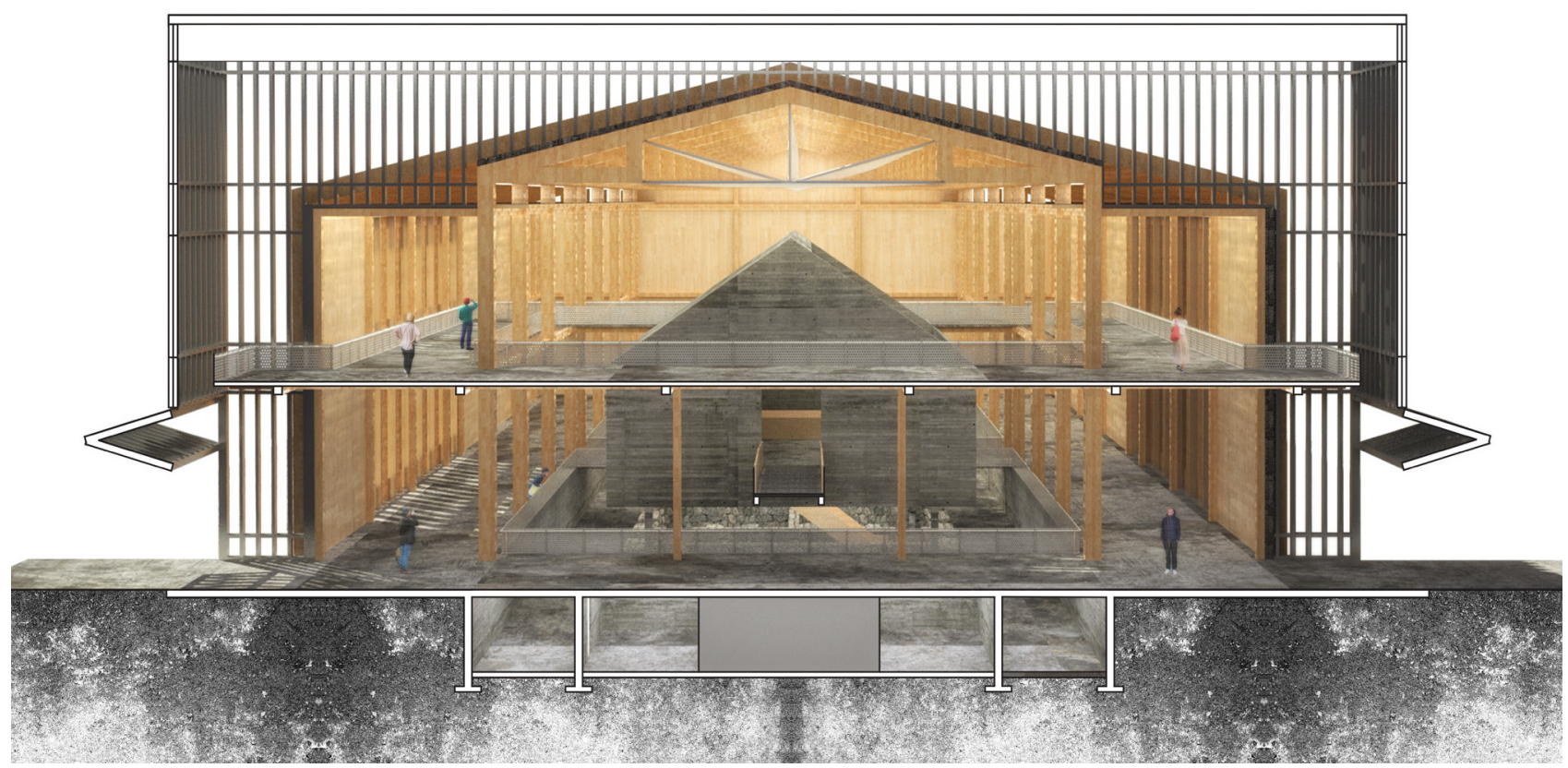

Section B-B 


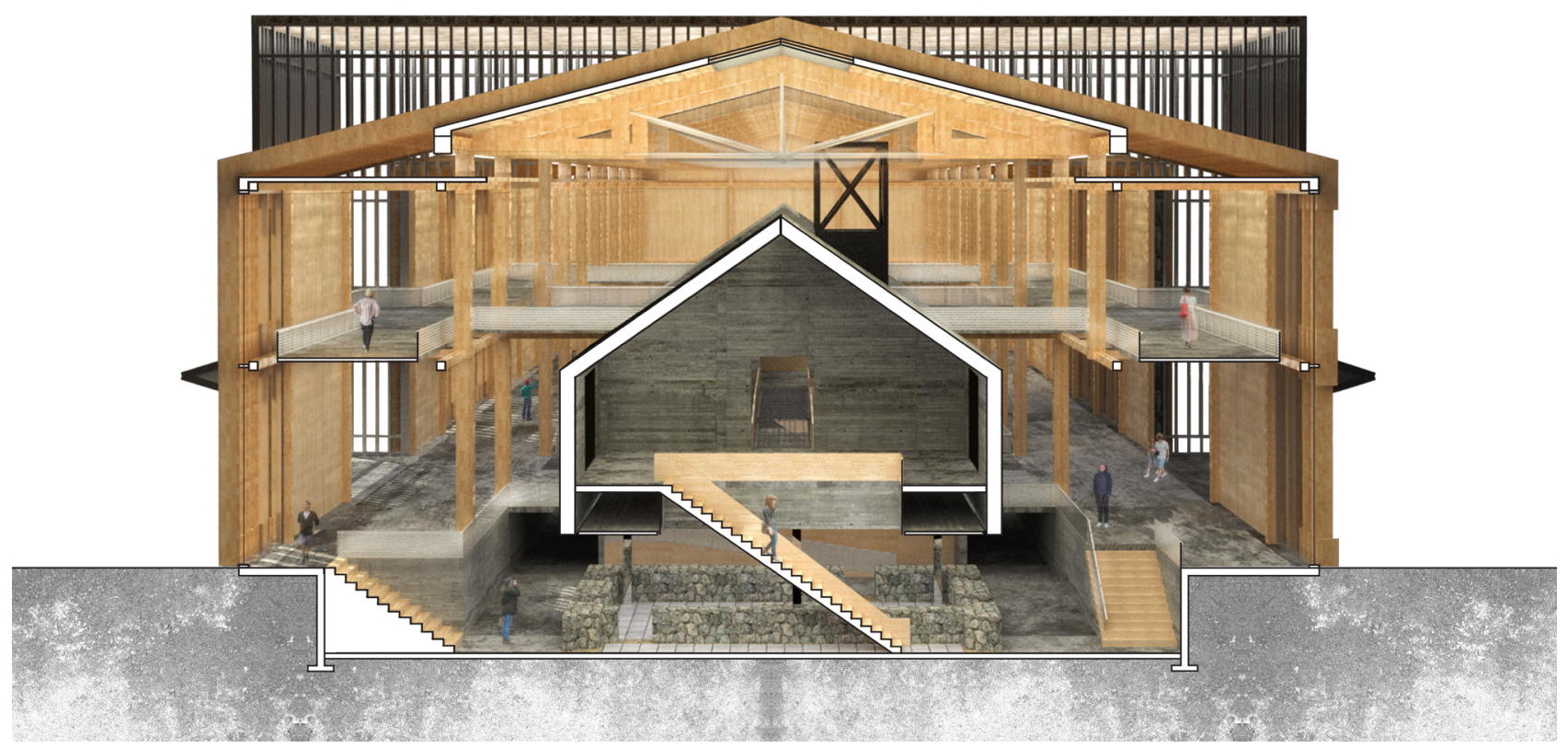

Section C-C

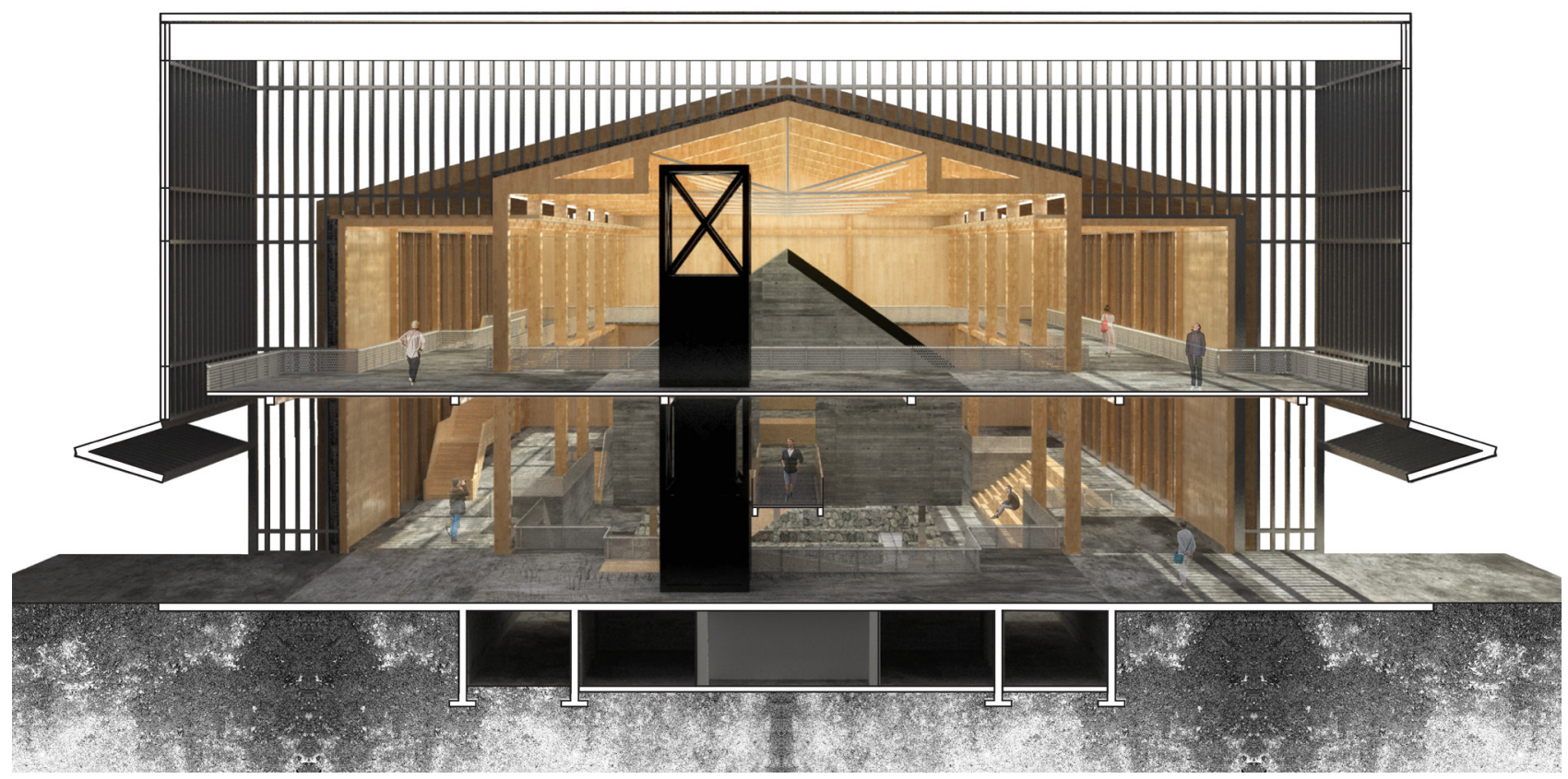

Section B-B North View 


\title{
Appendix B | Final Renders
}

\author{
List of Final Renders \\ Exterior View | Stanley Barrack Museum from the northwest corner \\ of the Enercare Centre \\ Interior View | Main entrance of Stanley Barrack Museum \\ Interior View | Ground floor looking over privates' barrack no.2 ruins \\ Interior View | Ground floor looking into the canteen ruins 1 \\ Interior View | Ground floor looking into the canteen ruins 2 \\ Interior View | Ground floor walkway over looking the canteen ruins \\ Interior View | Second floor bridge \\ Interior View | Lower level looking at the canteen ruins 1 \\ Interior View | Lower level looking at the canteen ruins 2 \\ Interior View | Lower level looking at Privates' Barrack no.2 ruins \\ and stairs \\ Interior View | Lower level looking at privates' barrack no.2 ruins \\ Interior View | Second floor exhibition and flex space \\ Interior View | Third floor interpretation level 1 \\ Interior View I Third floor walkway looking over the canteen ruins \\ Interior View | Overlooking the interpretation level and canteen ruins \\ Interior View | Third floor interpretation level 2 \\ Interior View | Third floor interpretation level 3 \\ Exterior View I Stanley Barrack Museum from the northeast side, \\ across from the Enercare Centre
}




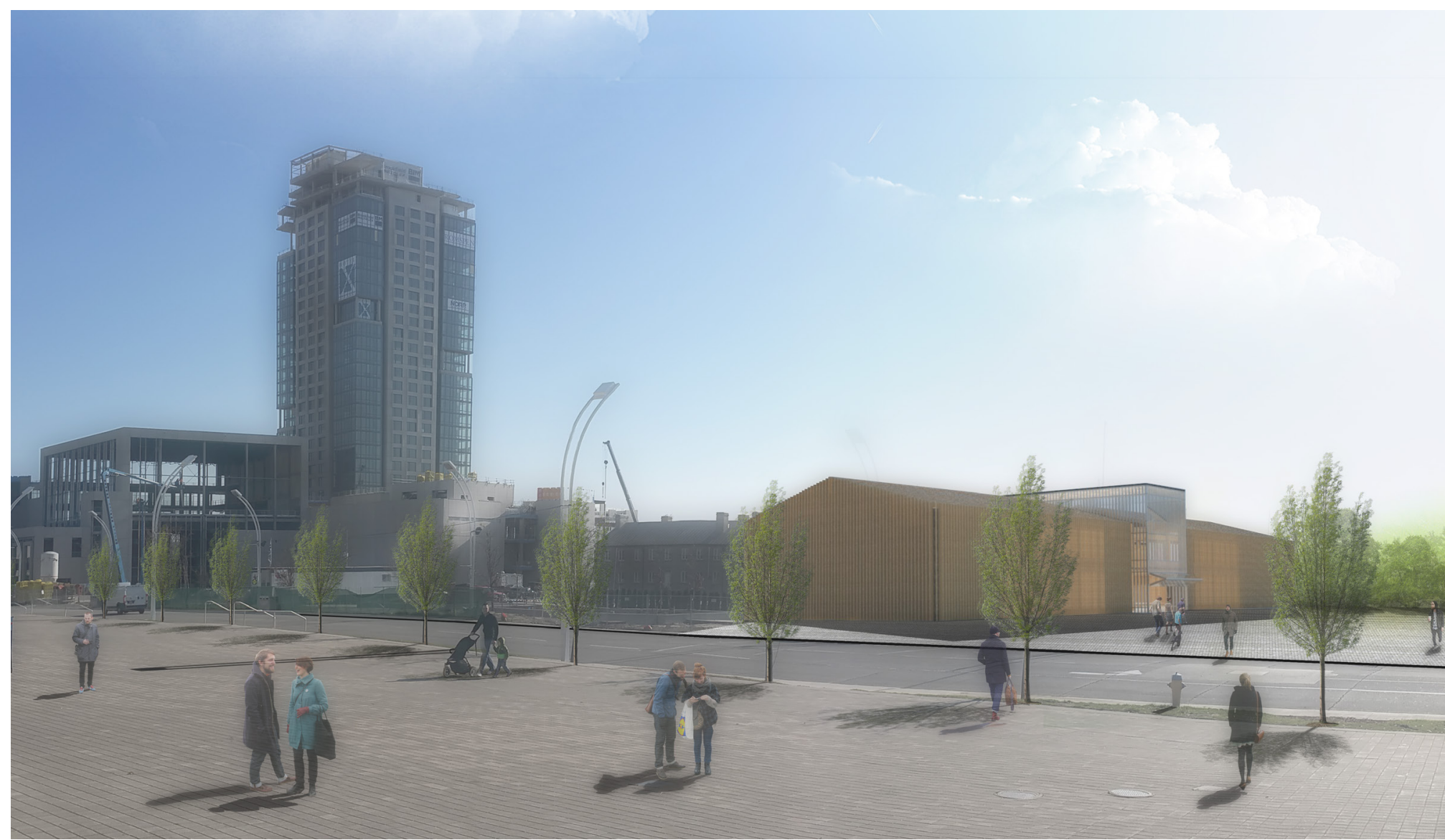

Exterior View | Stanley Barrack Museum from the northwest corner of the Enercare Centre 


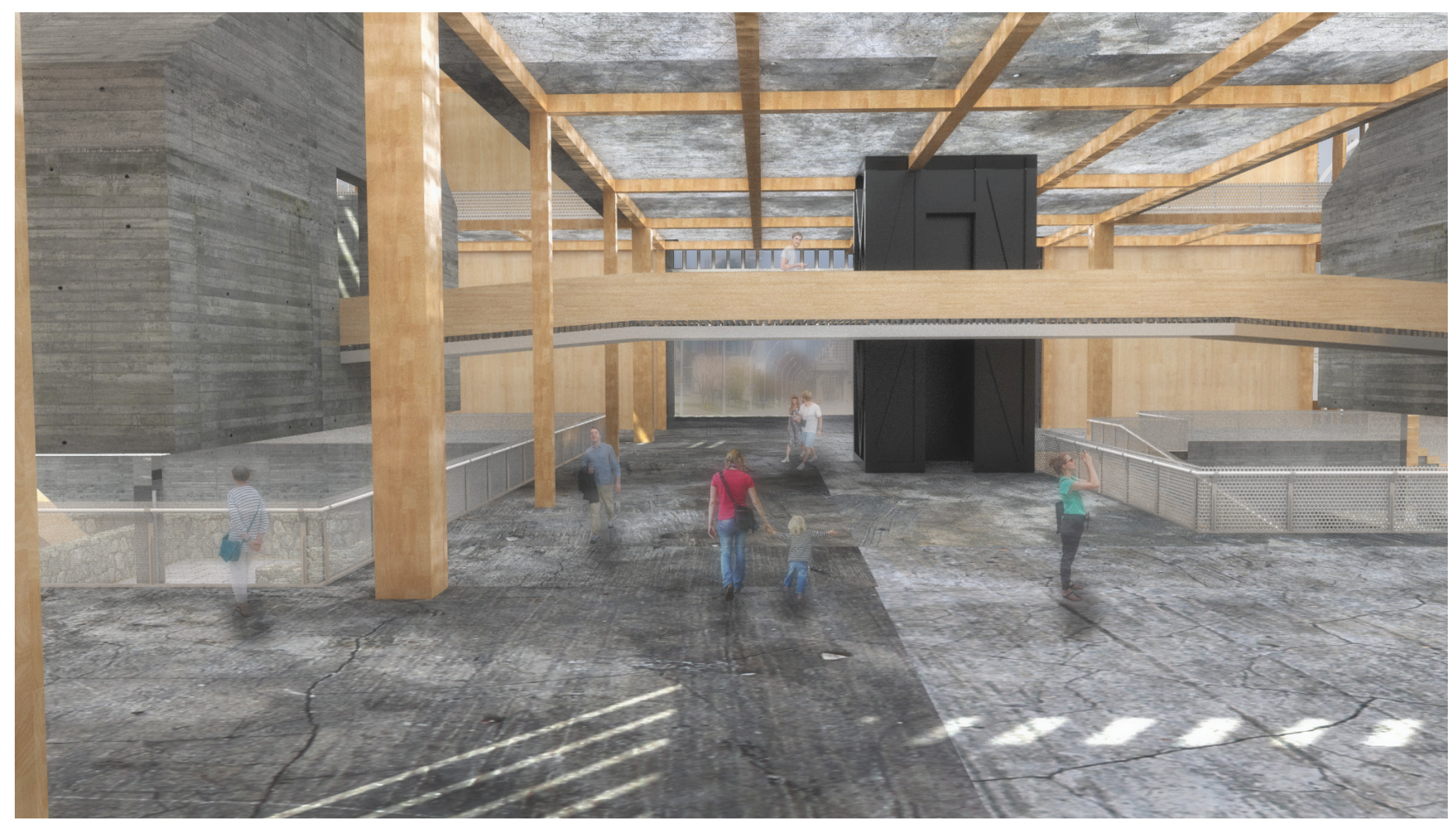

Interior View | Main entrance of Stanley Barrack Museum

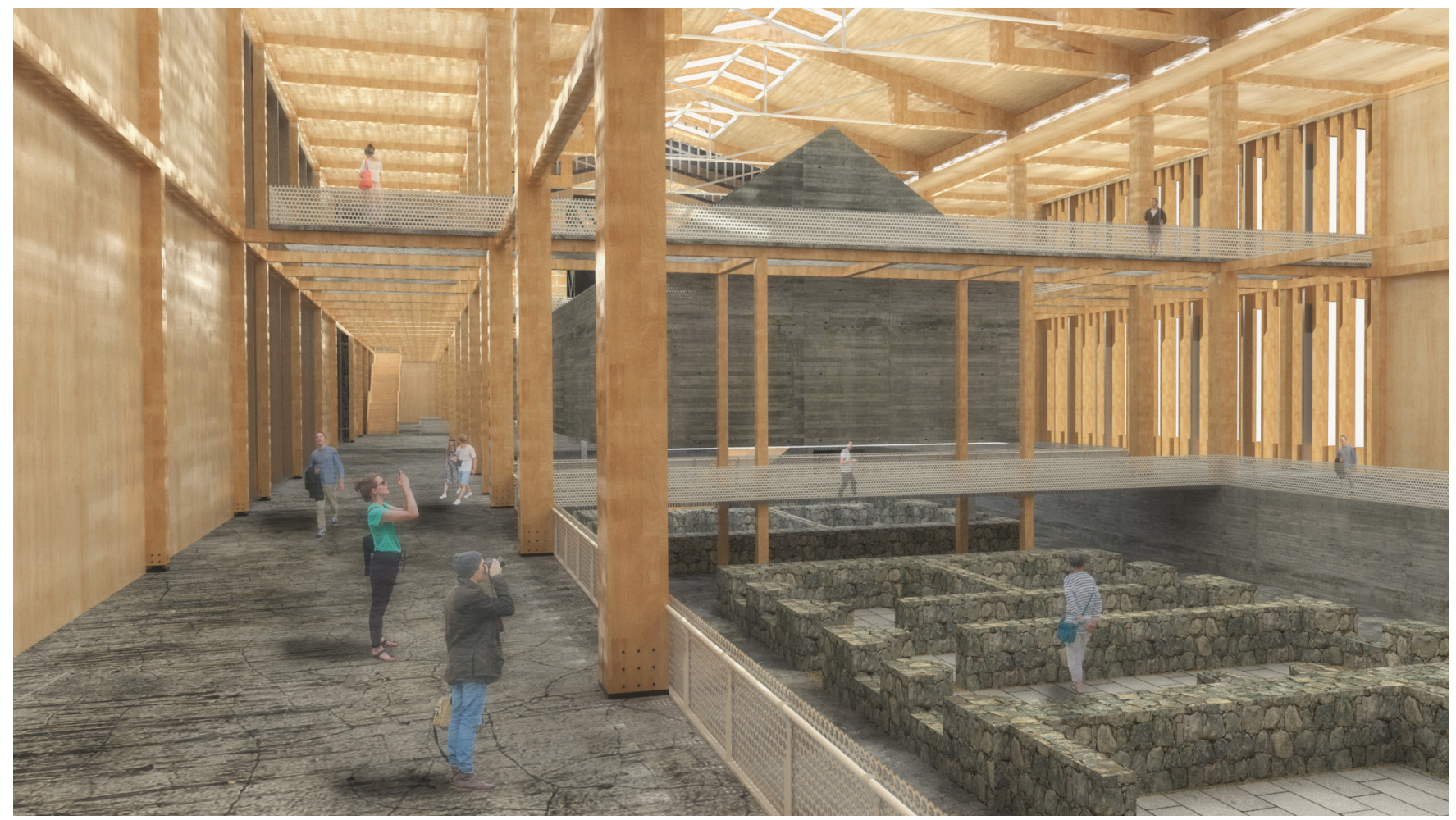

Interior View | Ground floor looking into the canteen ruins 1 


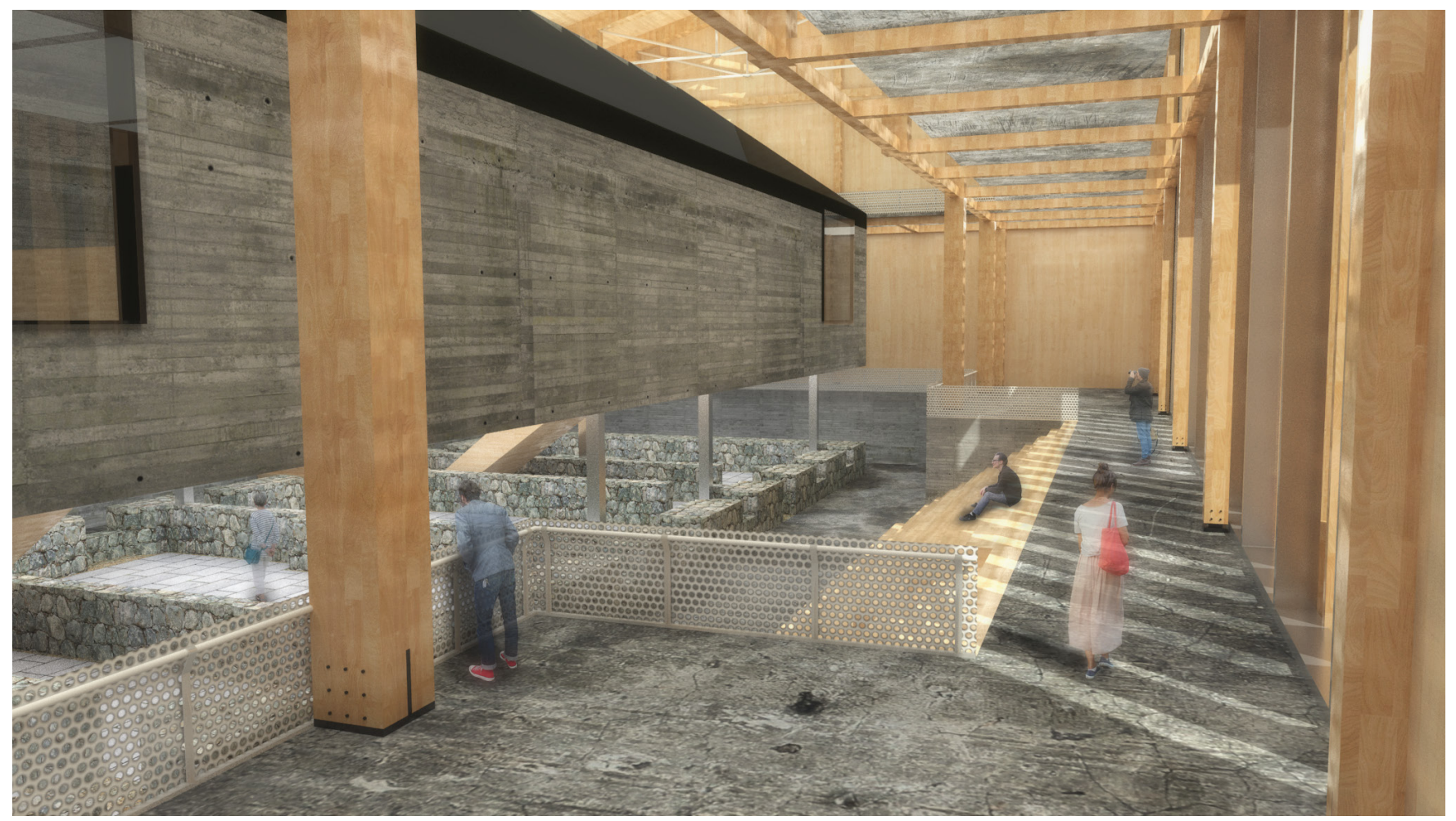

Interior View | Ground floor looking over privates' barrack no. 2 ruins

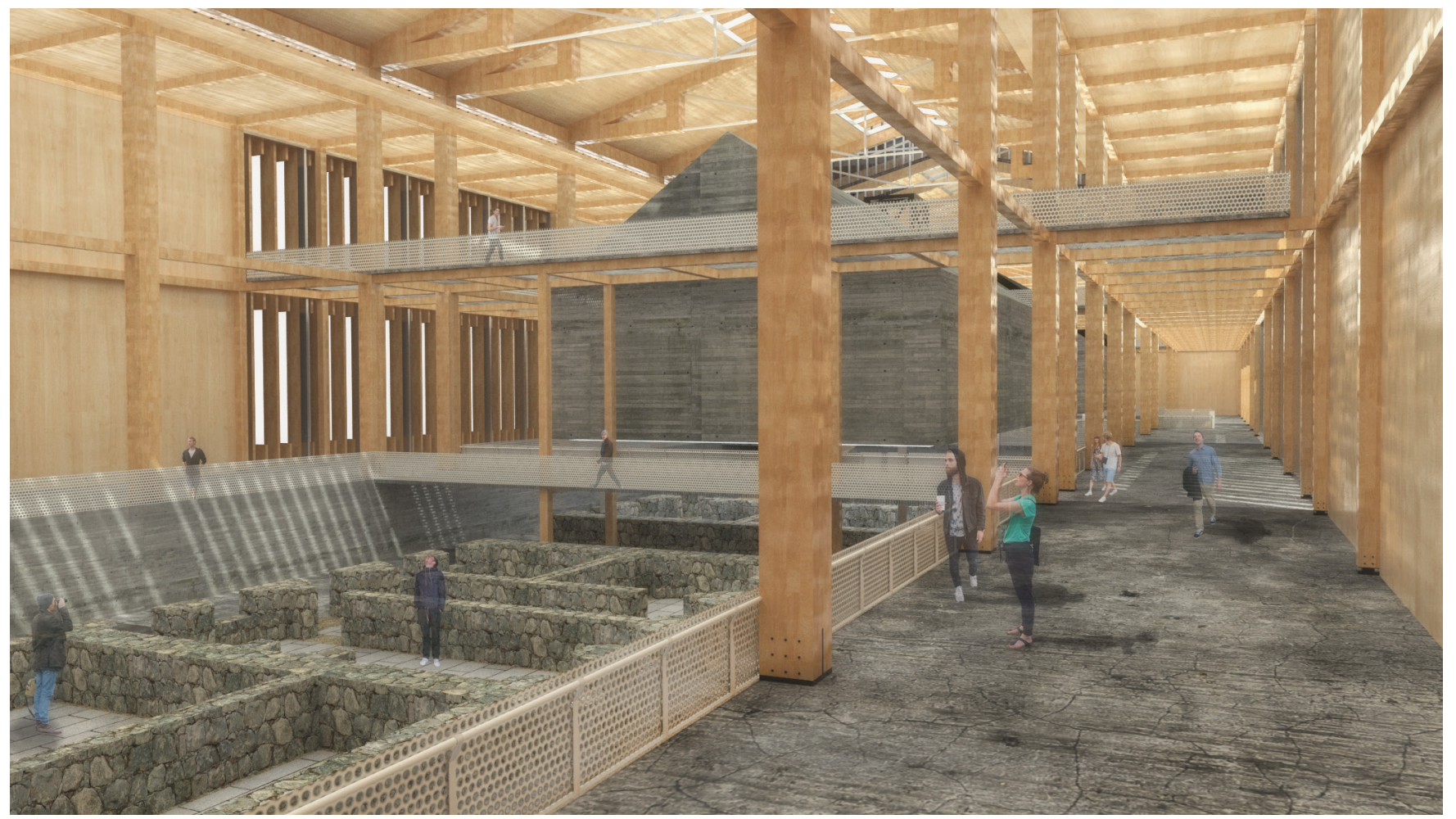

Interior View | Ground floor looking into the canteen ruins 2 


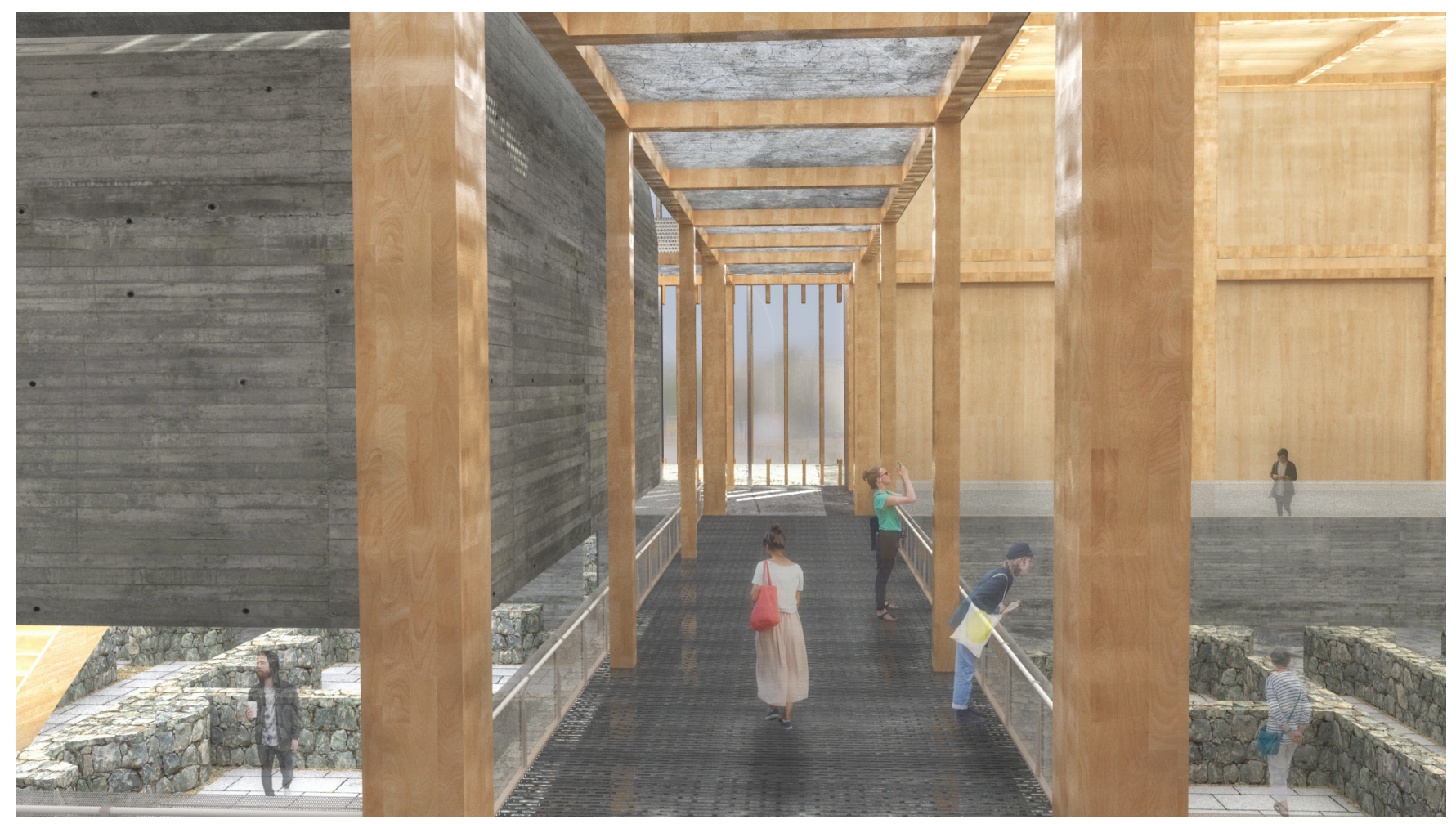

Interior View | Ground floor walkway over looking the canteen ruins

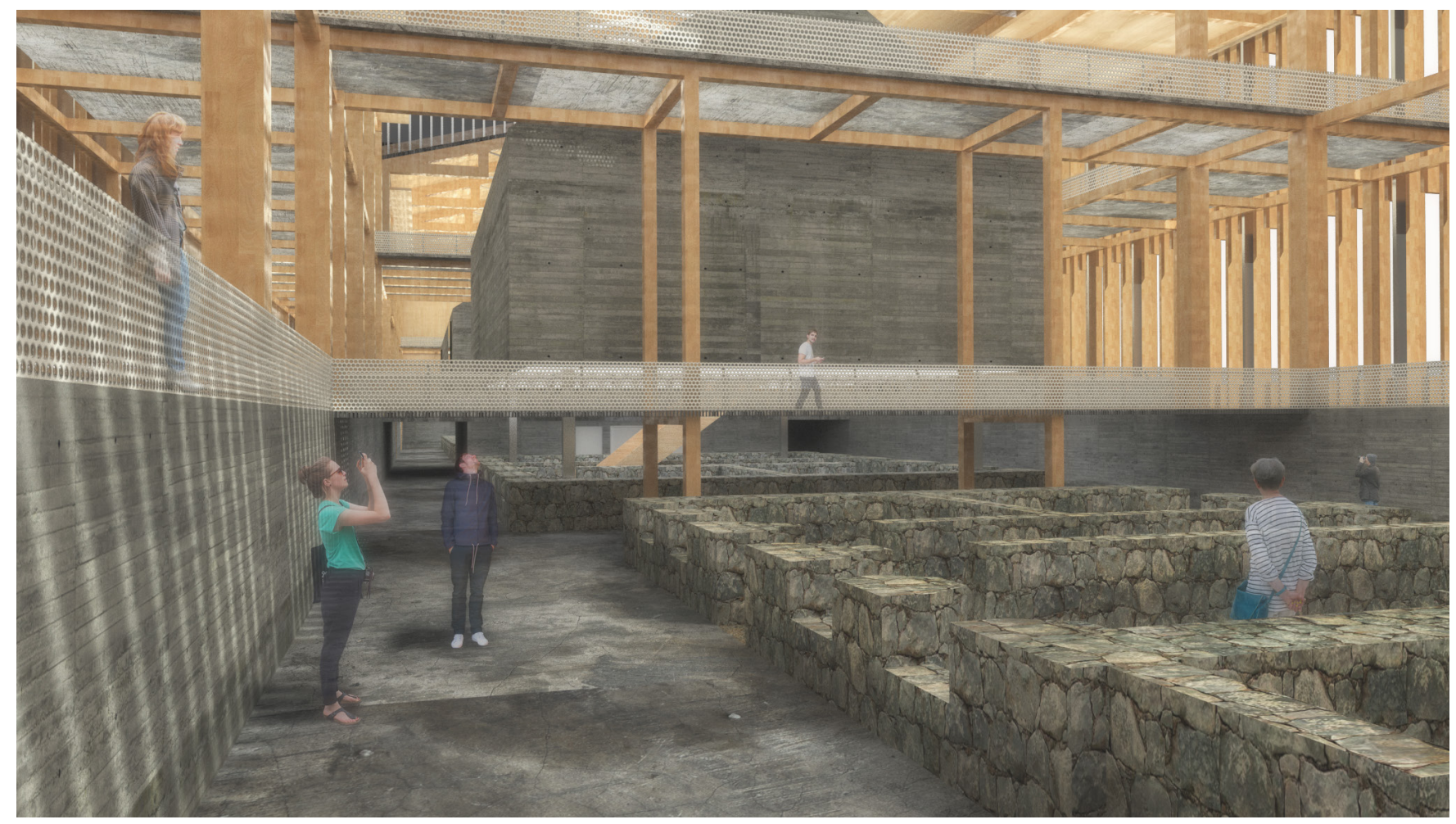

Interior View | Lower level looking at the canteen ruins 1 


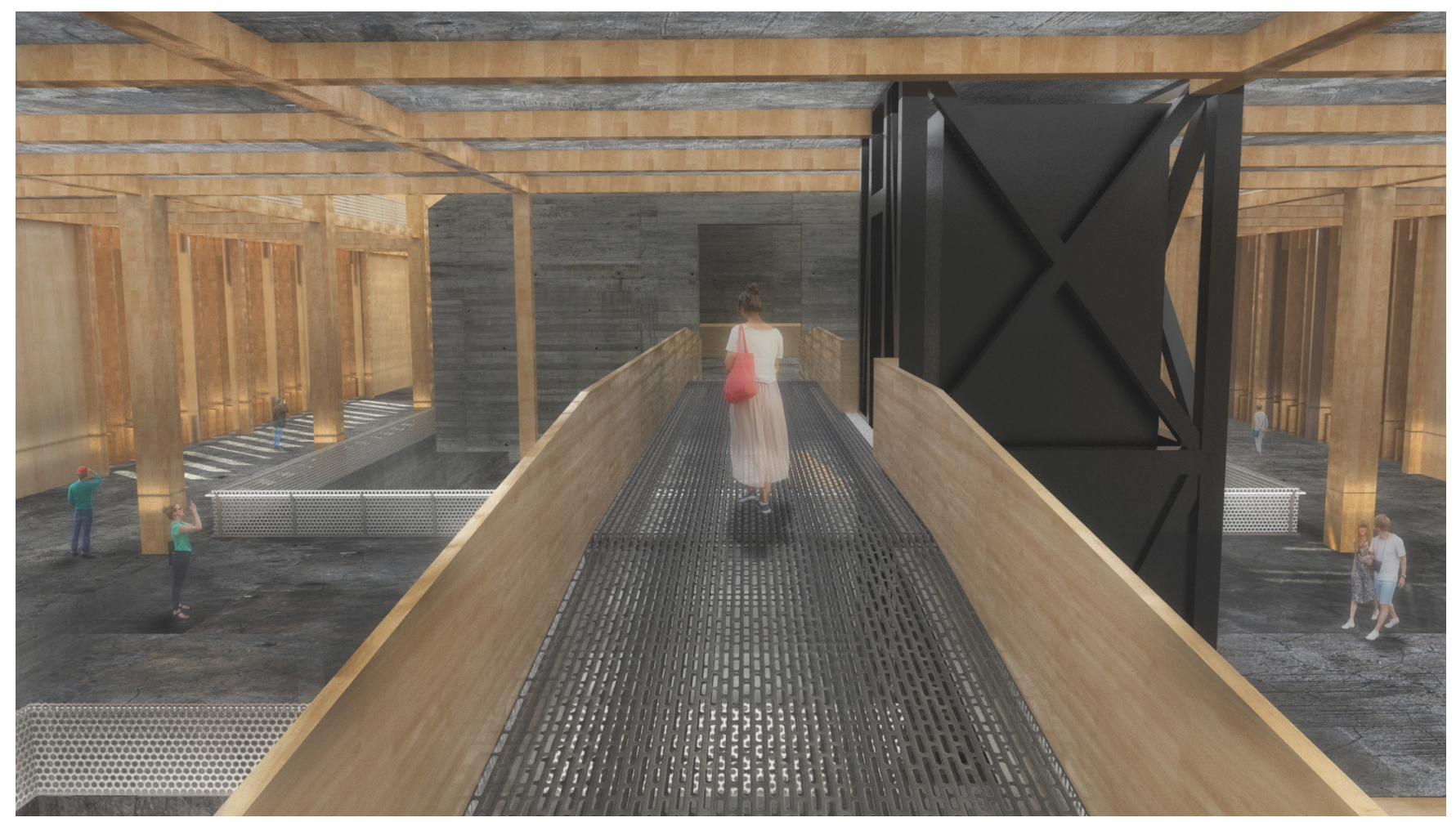

Interior View | Second floor bridge

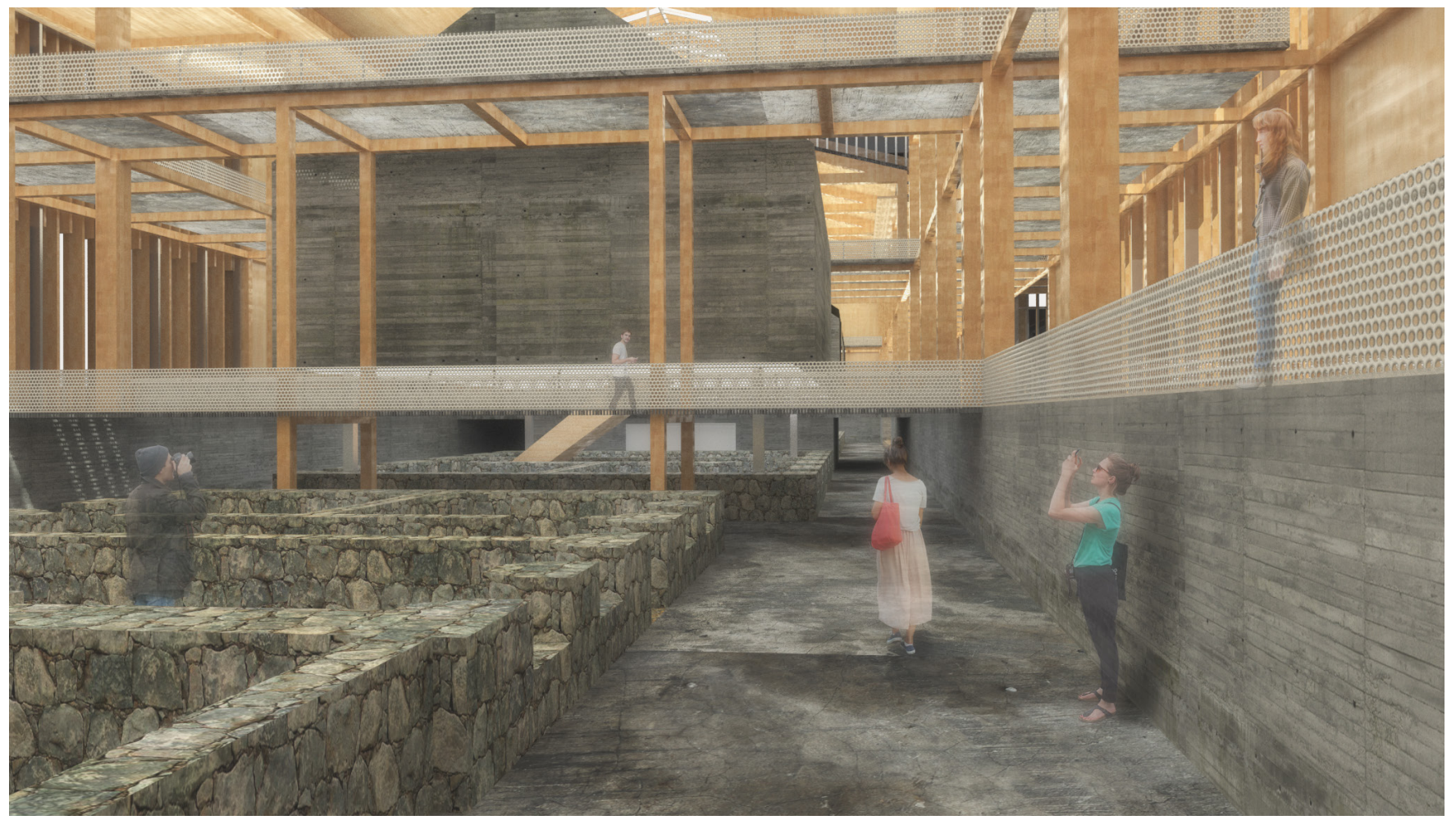

Interior View | Lower level looking at the canteen ruins 2 


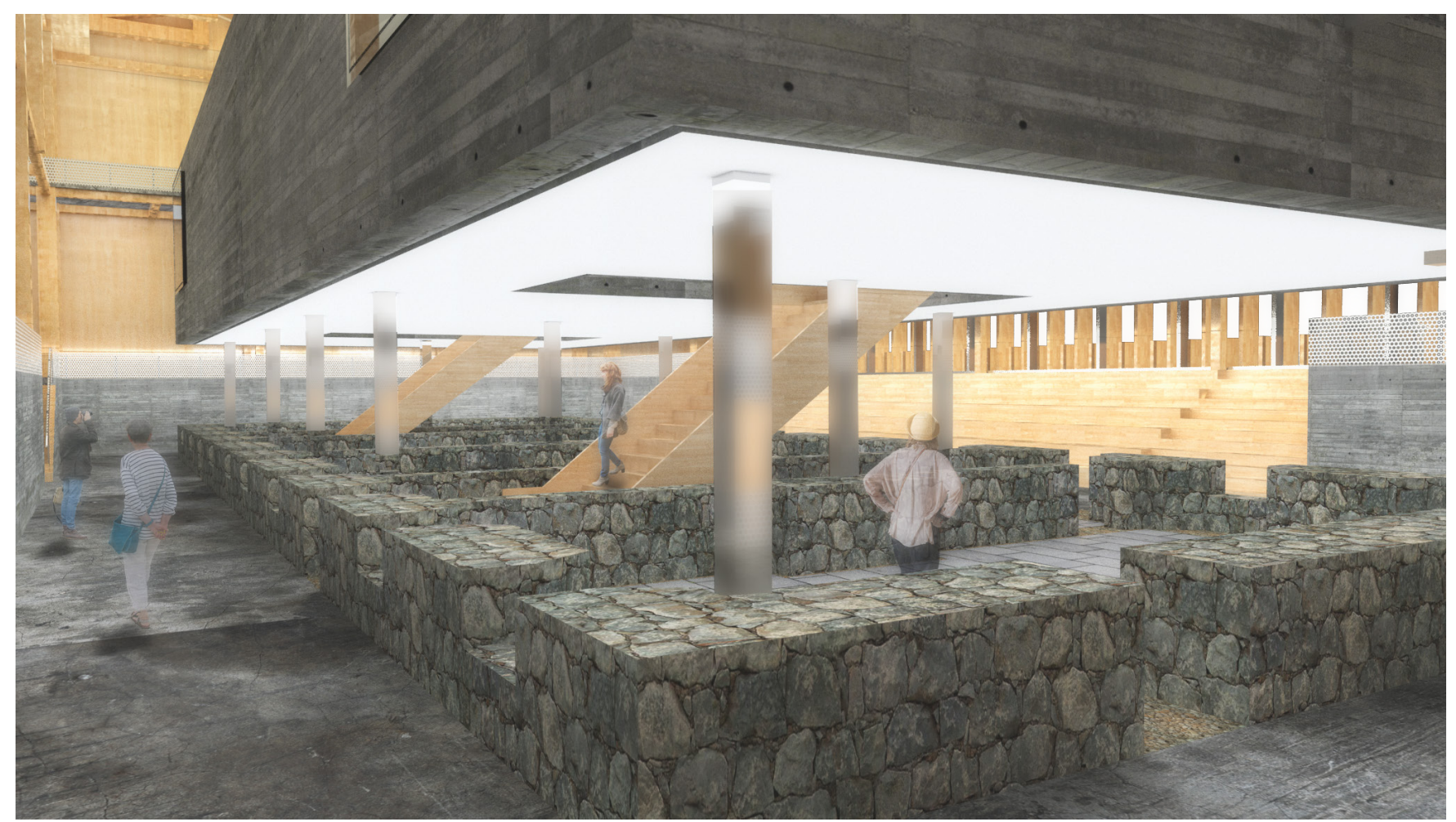

Interior View | Lower level looking at Privates' Barrack no. 2 ruins and stairs

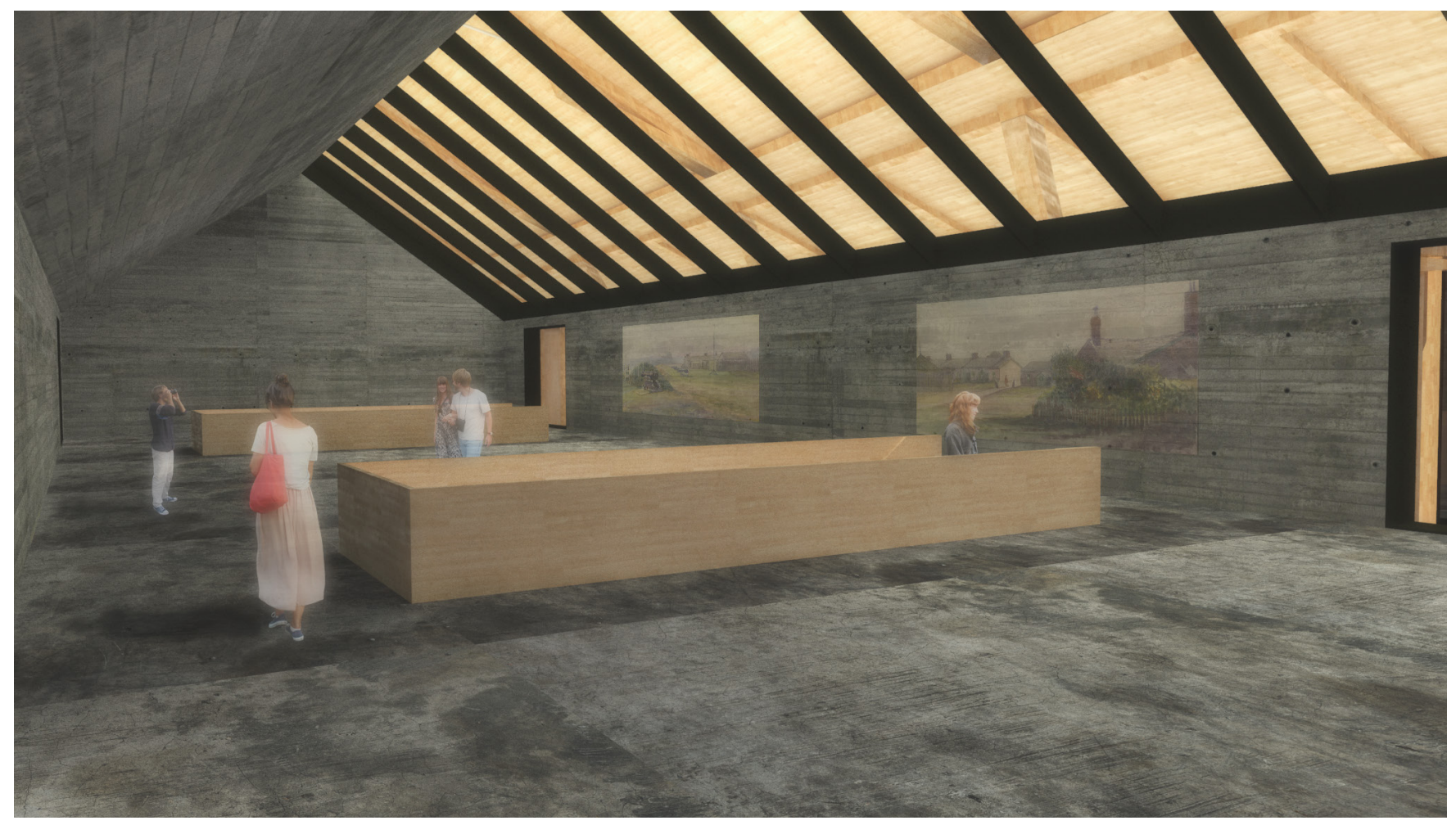

Interior View | Second floor exhibition and flex space 


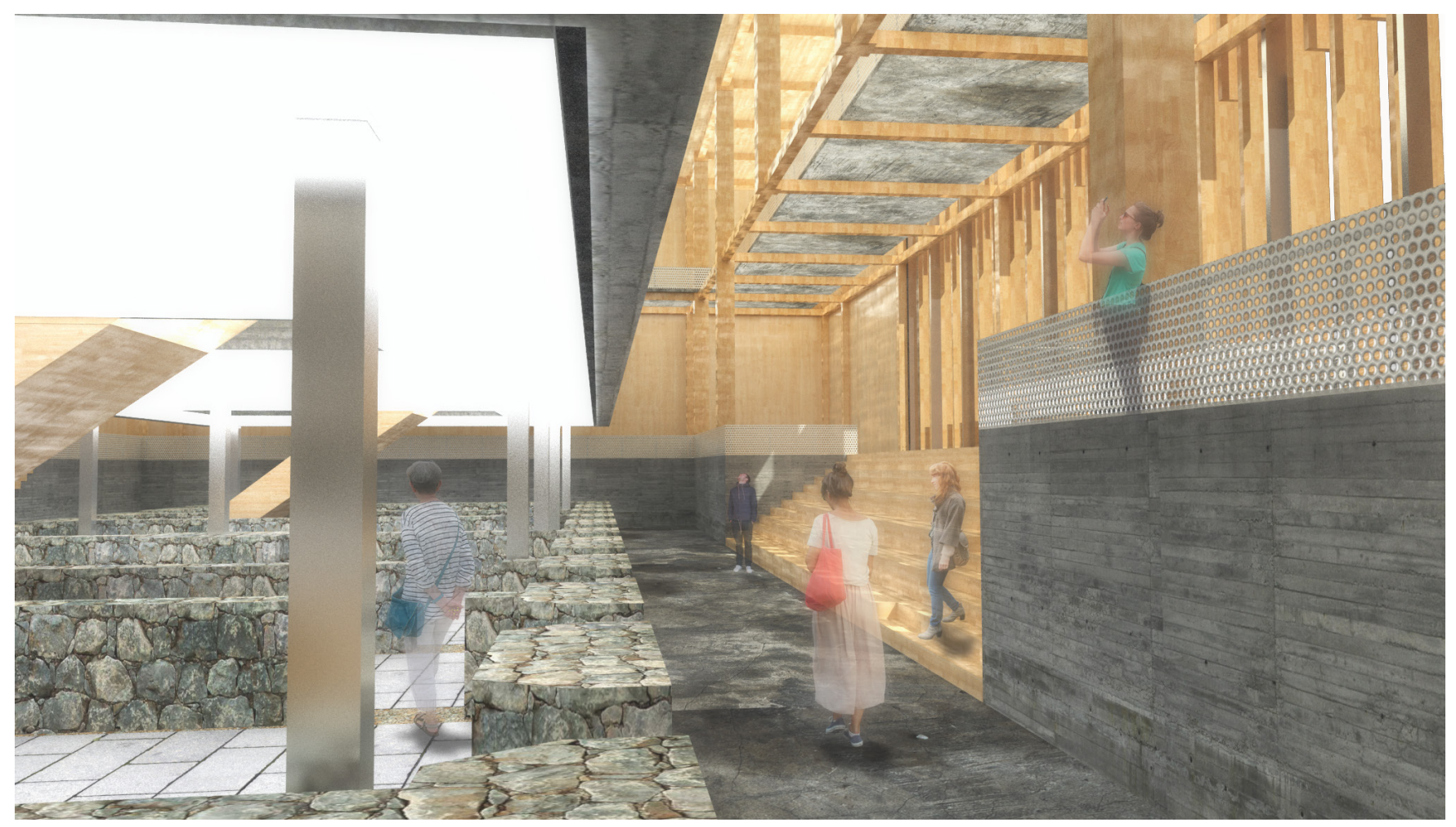

Interior View | Lower level looking at privates' barrack no. 2 ruins

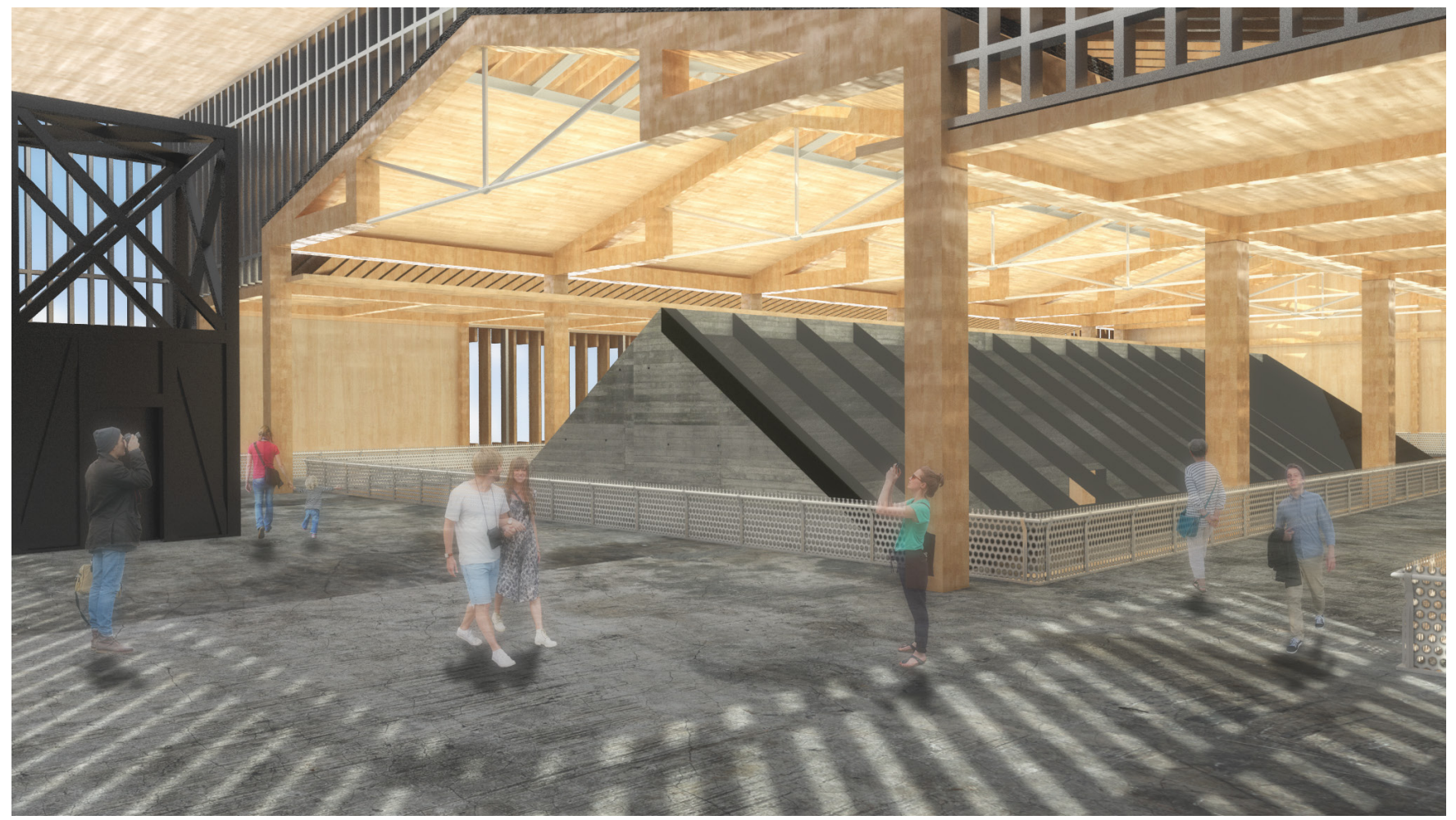

Interior View | Third floor interpretation level 1 


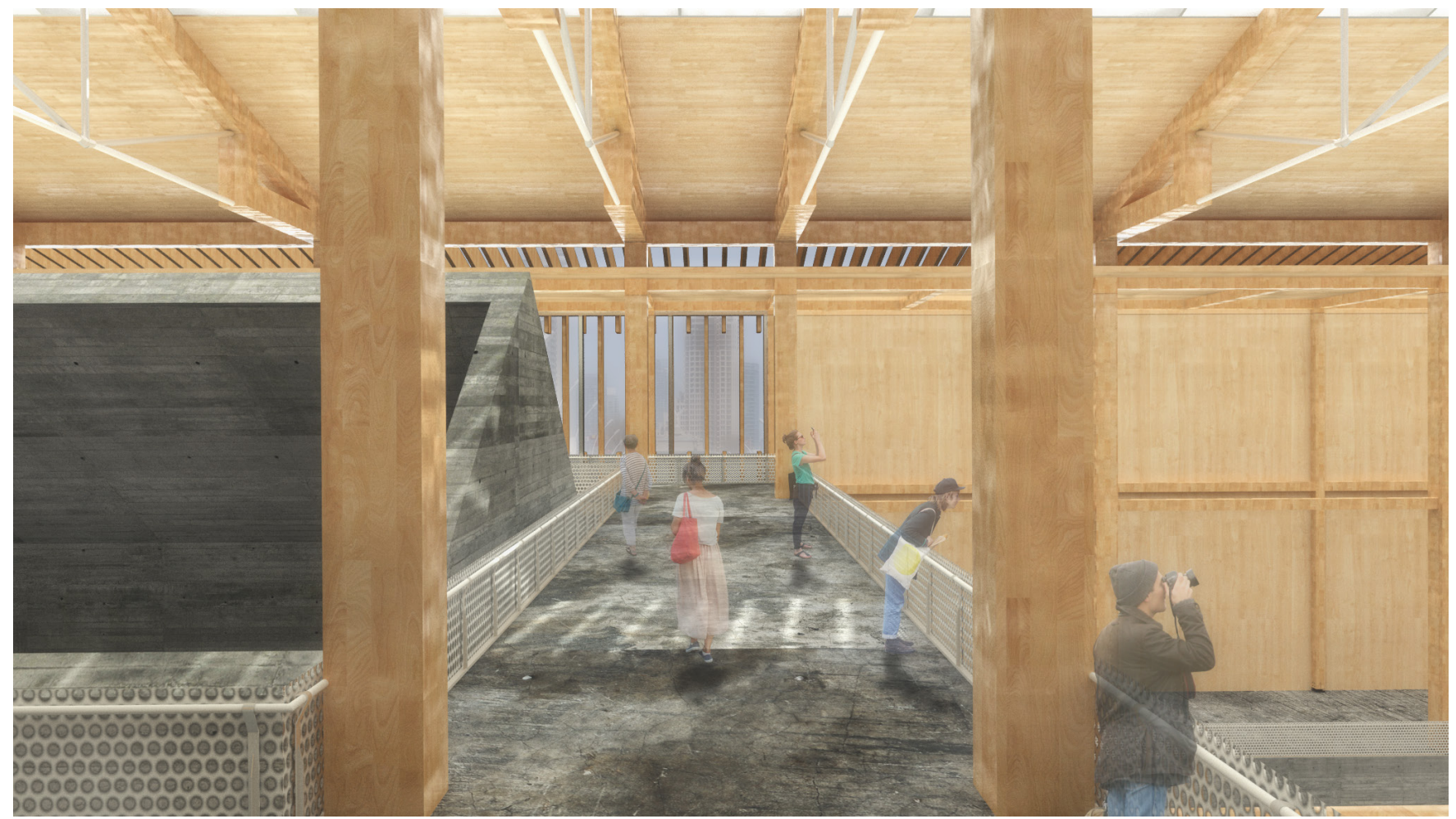

Interior View | Third floor walkway looking over the canteen ruins

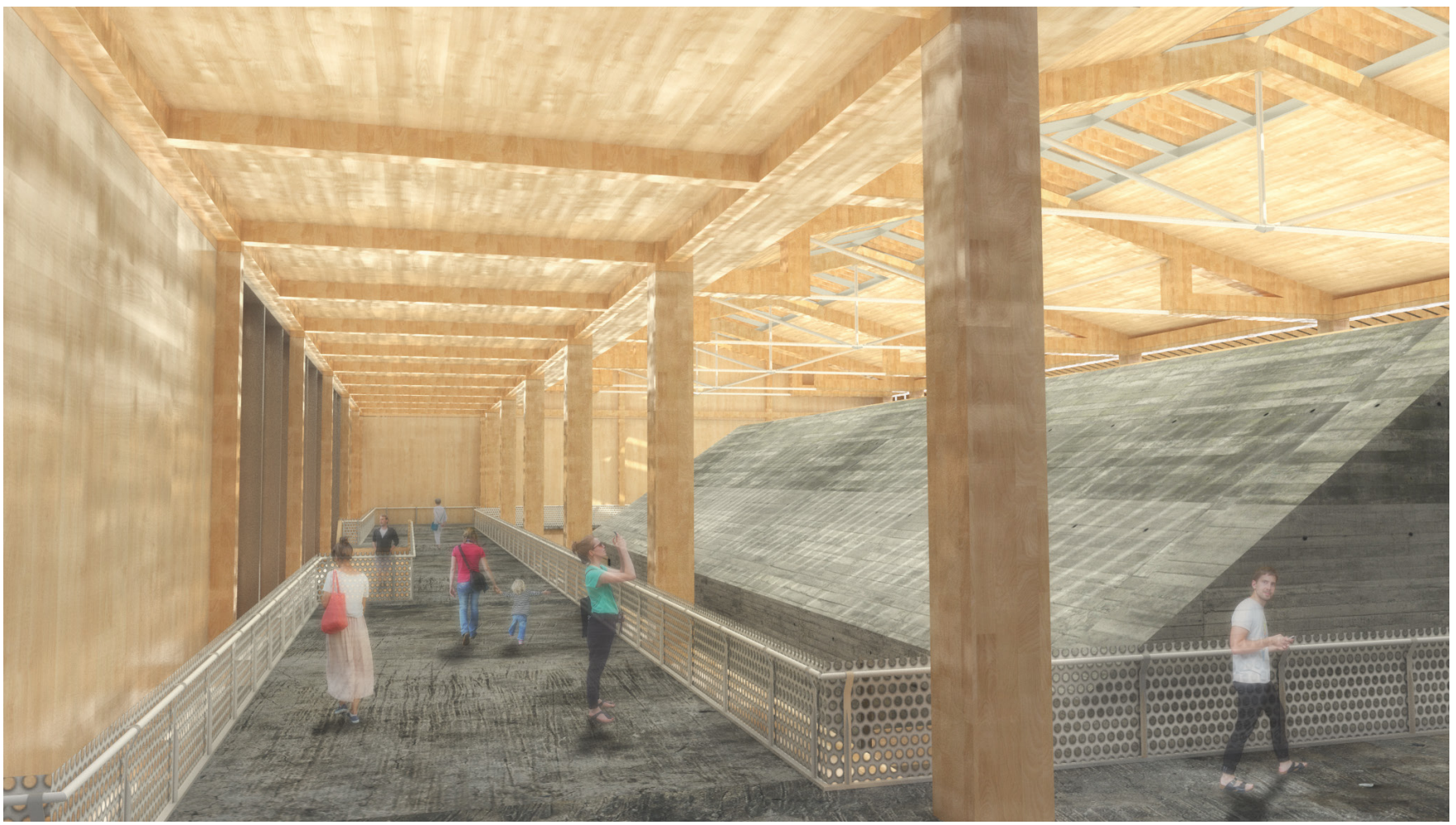

Interior View | Third floor interpretation level 2 


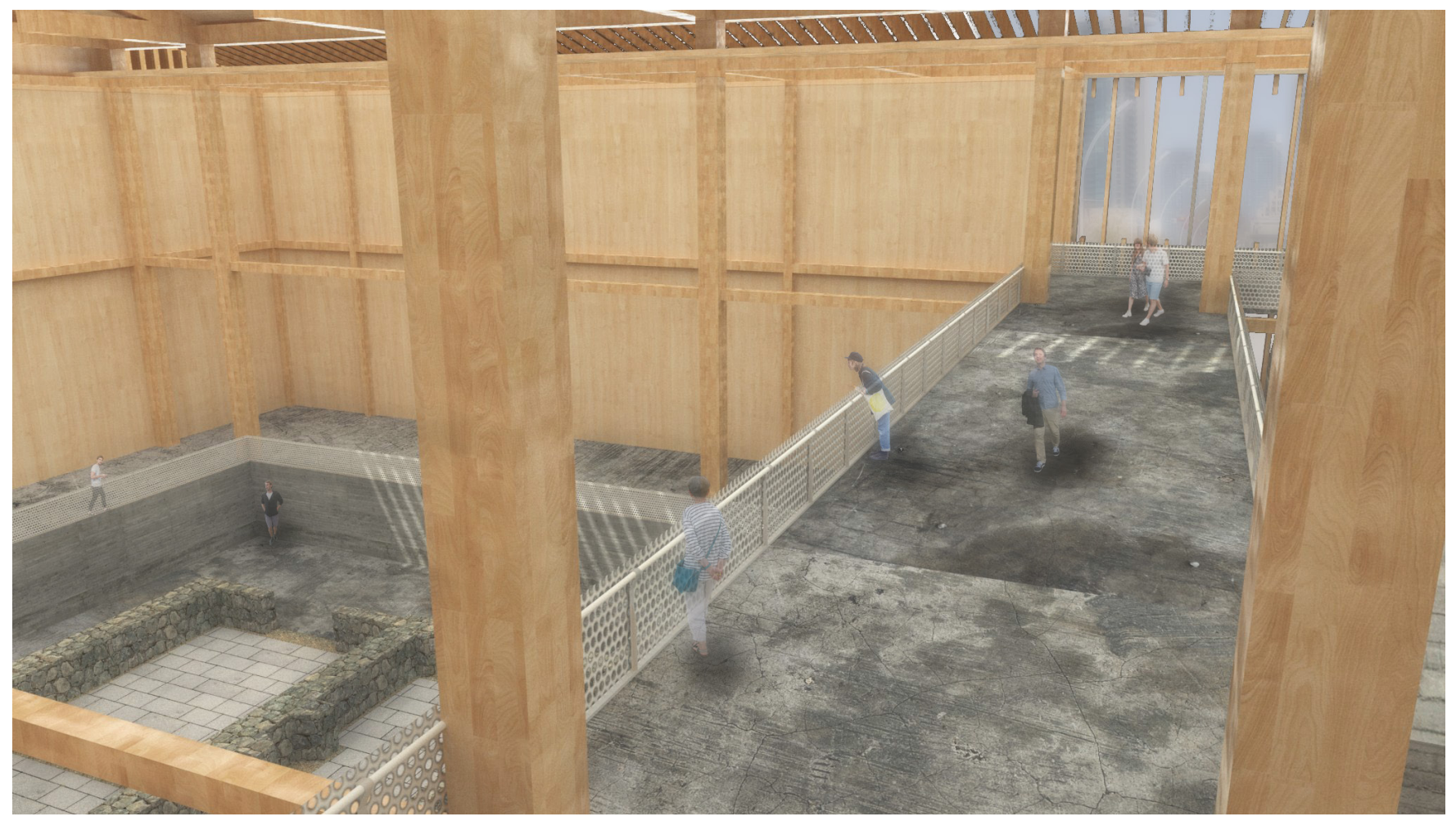

Interior View | Overlooking the interpretation level and canteen ruins

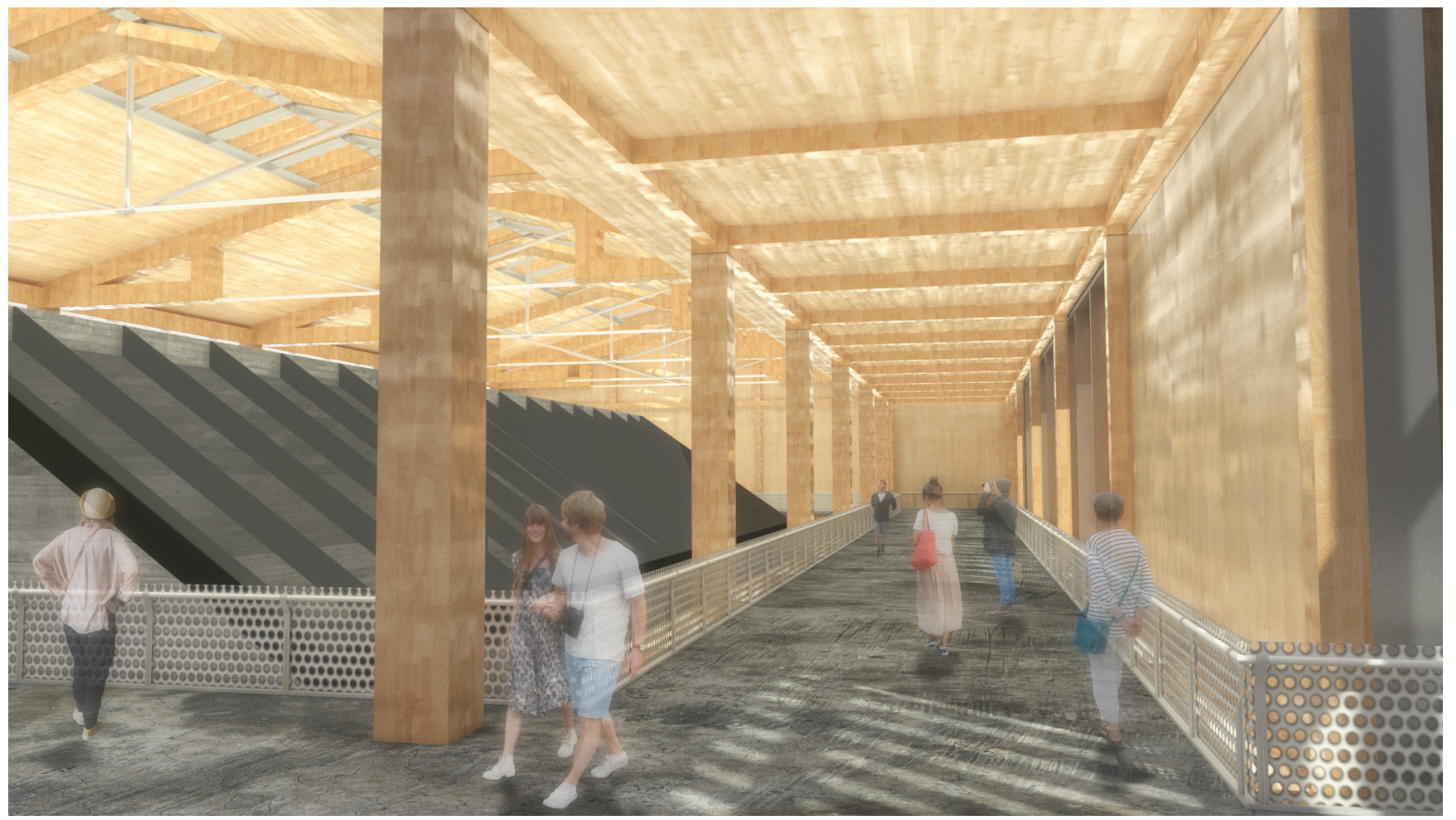

Interior View | Third floor interpretation level 3 


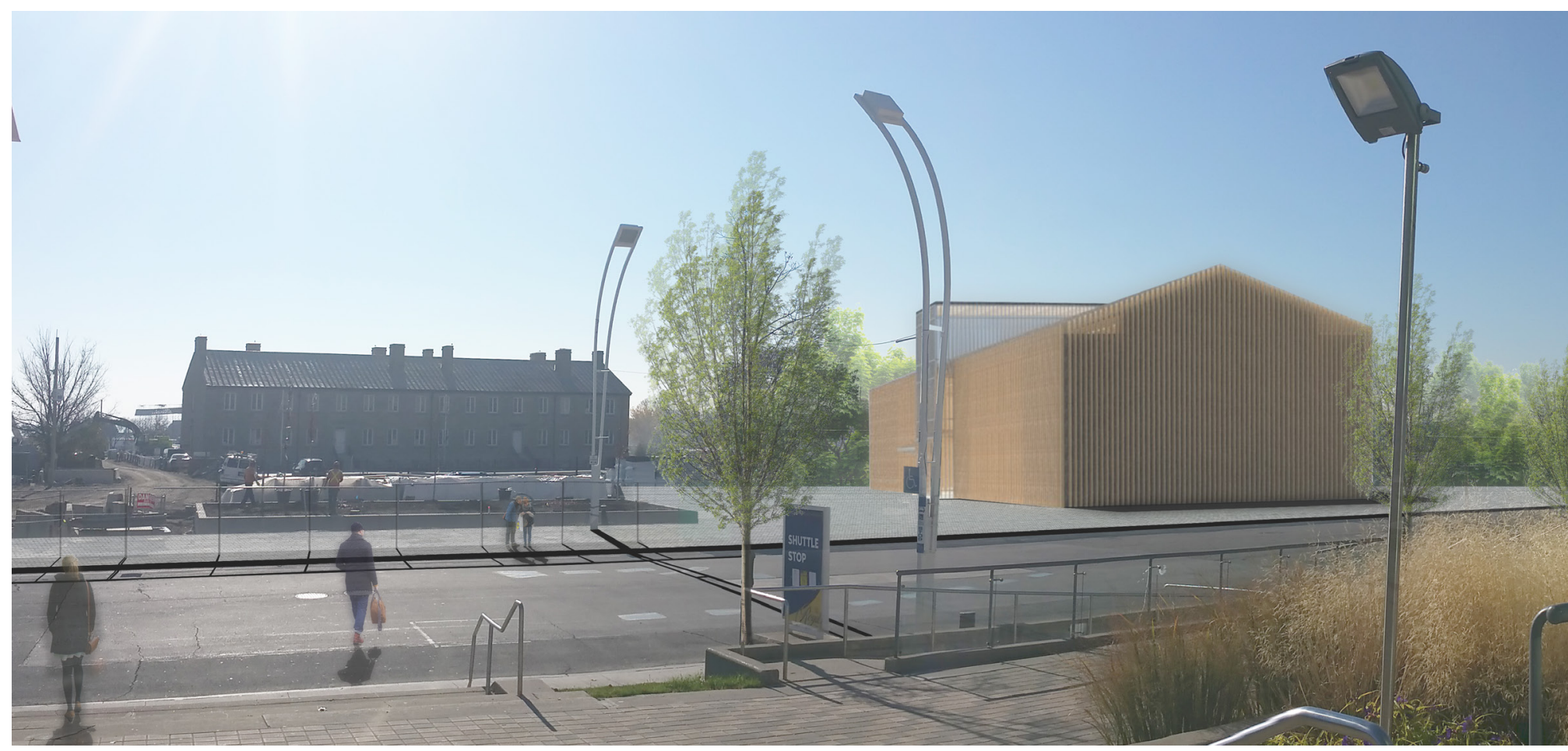

Exterior View | Stanley Barrack Museum from the northeast side, across from the Enercare Centre 


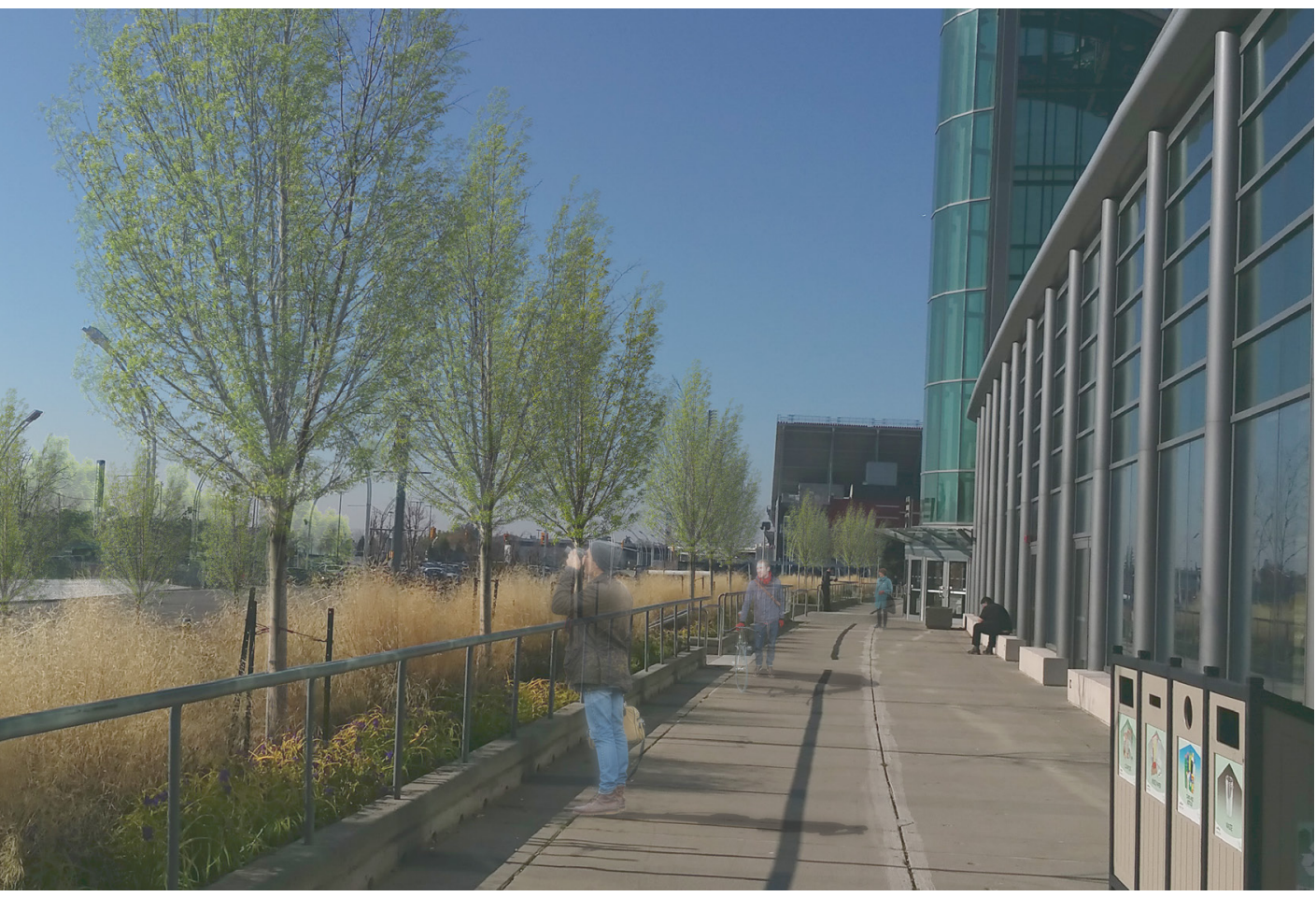




\section{Appendix C | Design Development}

Fig. 1: (top) Sketch of master plan for Stanley Barrack Museum

Fig. 2: (middle) Sketch elevation for Stanley Barrack Museum

Fig. 3: (bottom right) Sketch of interior perspective of ruins

Fig. 4: (bottom Left)Sketch section through the ruins

Opposite

Fig. 5: (top) Detail sketch of musuem form and facade 1

Fig. 6: (middle) Detail sketch of museum form and facade 2

Fig. 7: (bottom) Detail preliminary site plan for Stanley Barrack Museum
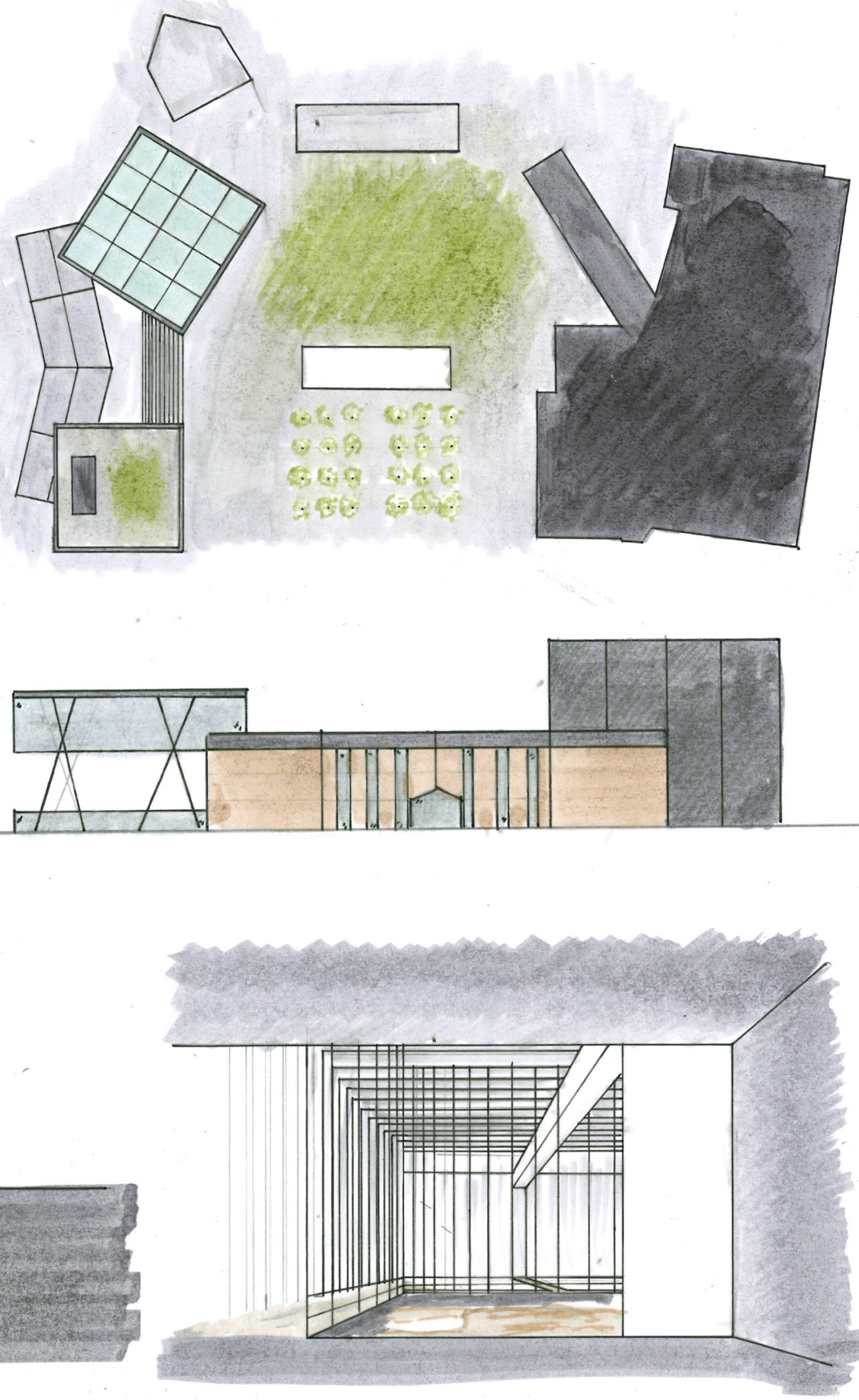

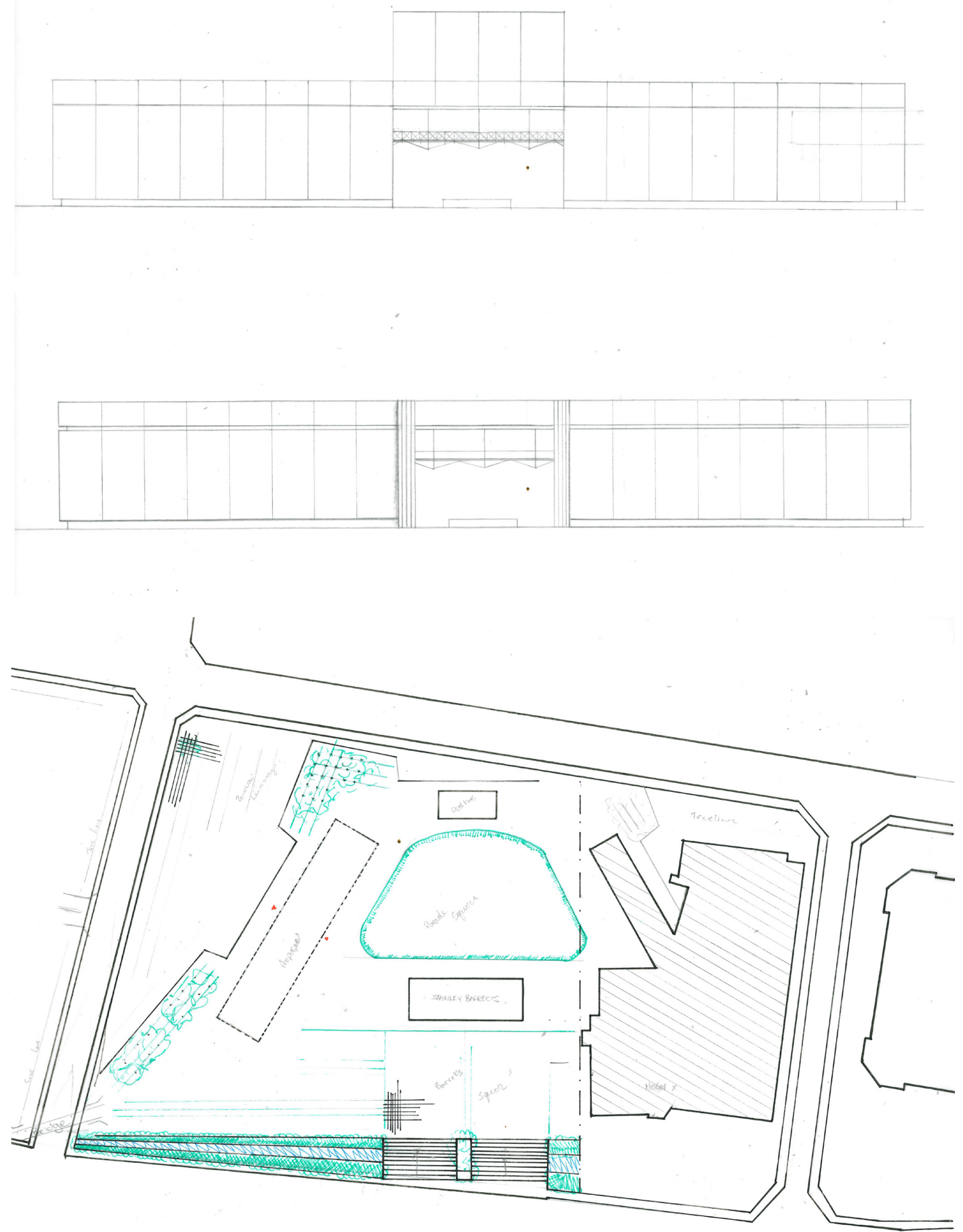


\section{Appendix D | Design Process Circulation Model}
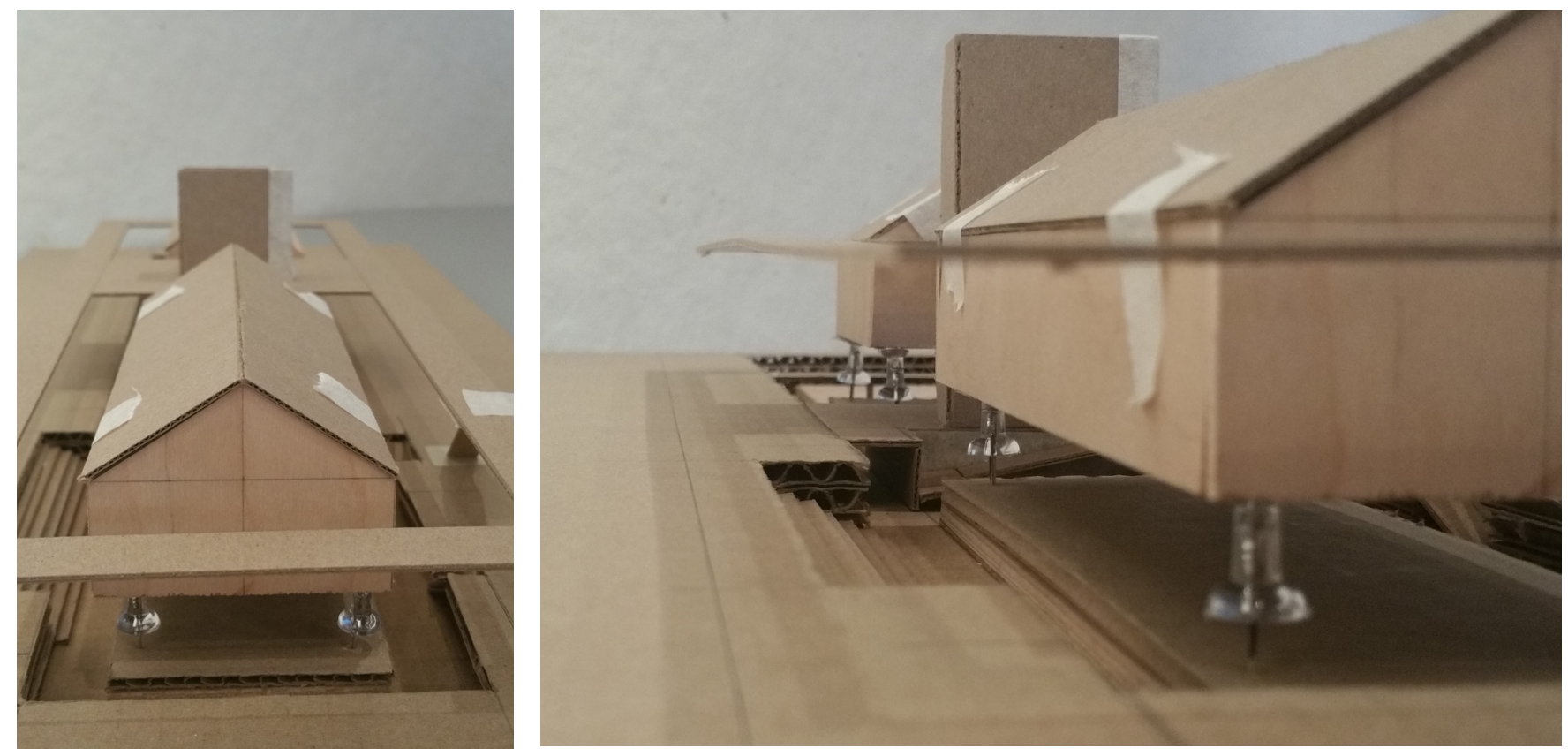

Fig. 1: (top left) Exploration model of interior circulation and volume that traces the ruins below

Fig. 2: (top right) Exploration model of interior circulation of the main stairs and seating area

Fig. 3: (bottom) Exploration model of overall view

\section{Opposite}

Fig. 4: (top) Exploration model of interior circulation of how visitors can travel to the third floor

Fig. 5: (bottom left) Exploration model of interior circulation, alternative circulation of third floor 1

Fig. 6: (bottom right) Exploration model of interior circulation, alternative circulation of third floor 2

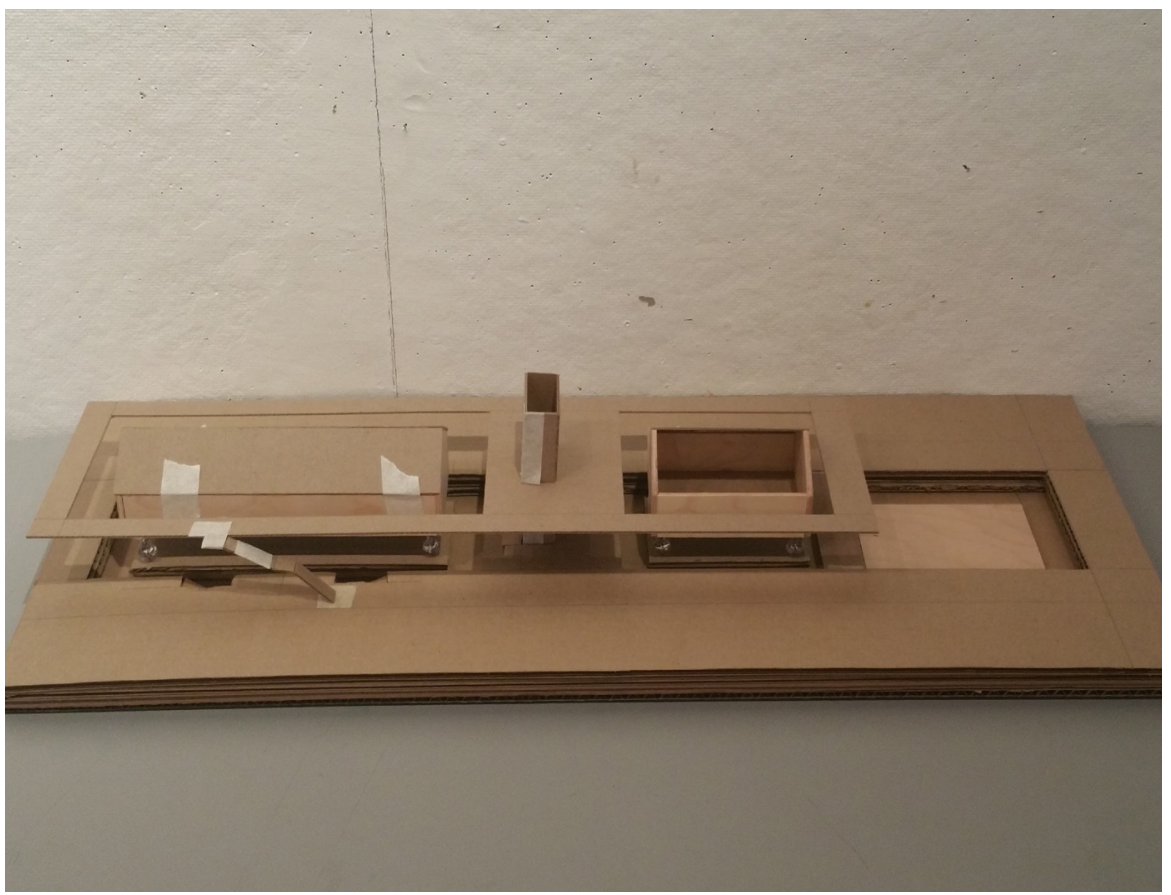



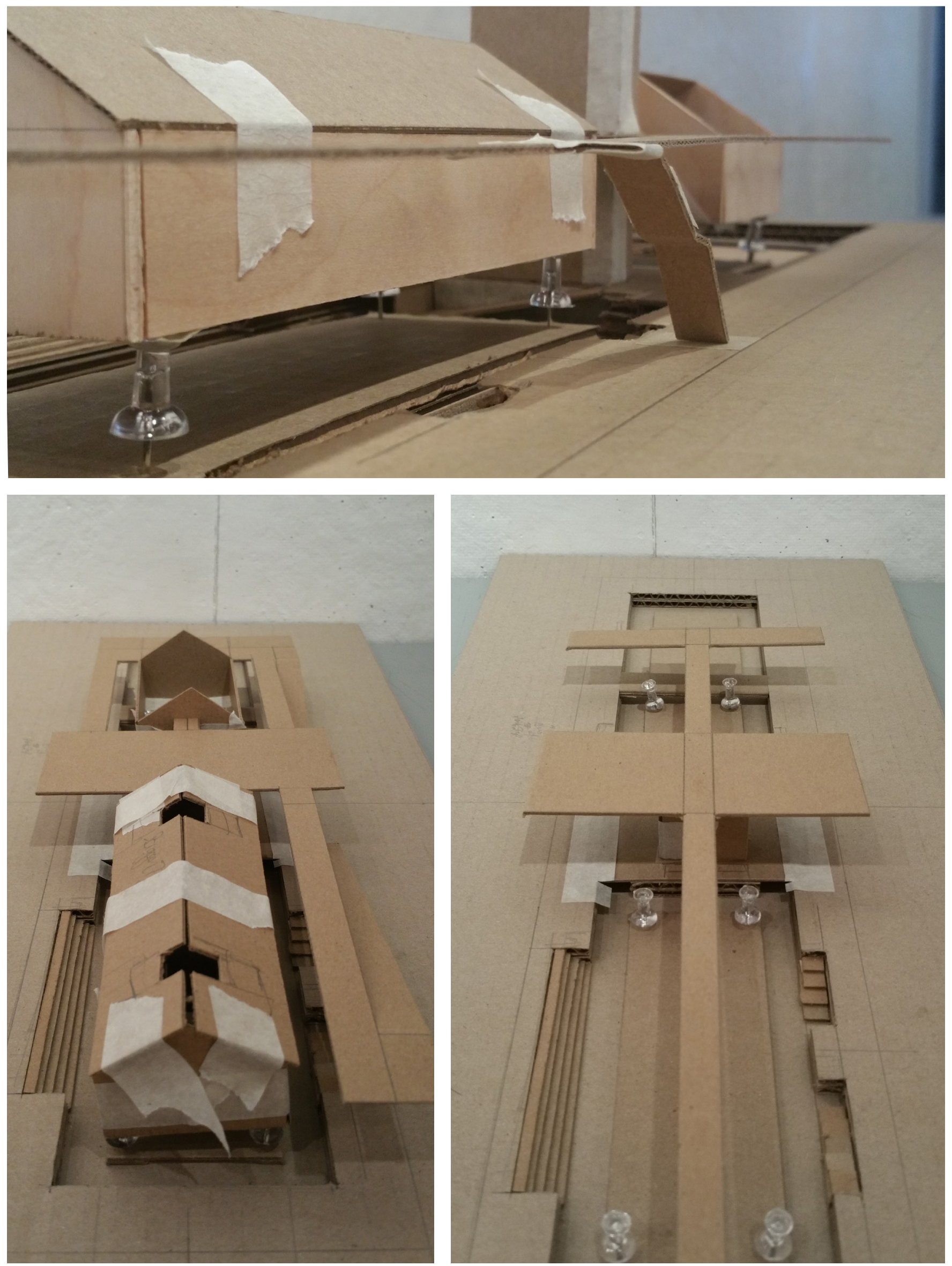


\section{Appendix E | Design Process of Envelope System}

Fig. 1: (top left and right) Detail section of the facade and its relationship to the volume Fig 2a: (bottom left) Detail section of the approach to the ruins and transition to the lower level

Fig. 2b: (bottom right) Detail section of the transition to the lower level with seating

\section{Opposite}

Fig. 3: (top left and right) Detailed section of building facade with a window

Fig. 4: (row 2 left and right) Detailed section of building facade with varying density of vertical fins

Fig. 5: (row 3 left and right) Detailed section of building facade looking at different methods of creating vertical shutters and fins Fig. 6: (bottom left and right) Detailed section of building facade looking at how to bend and twist vertical fins to create a dynamic facade
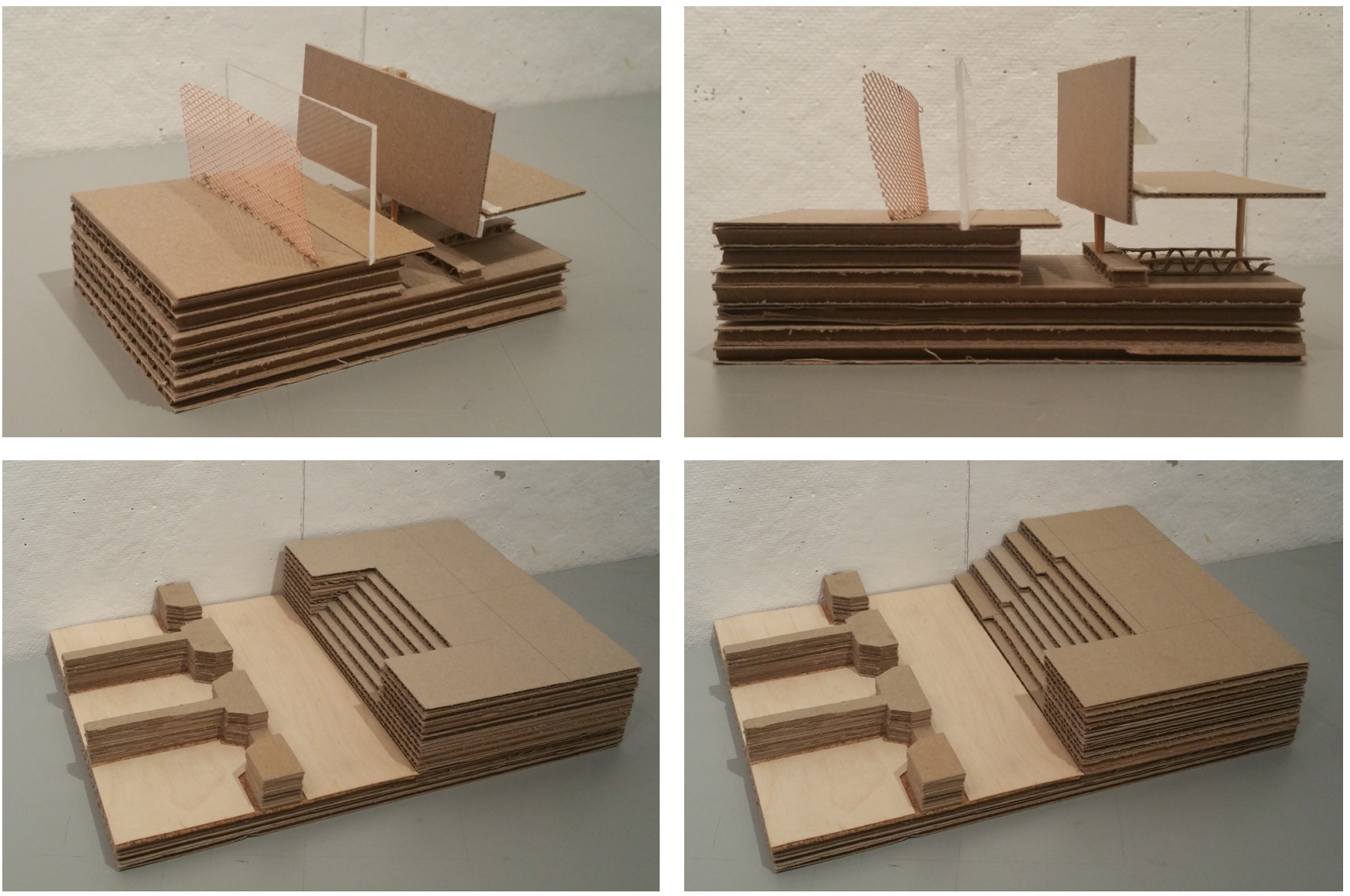

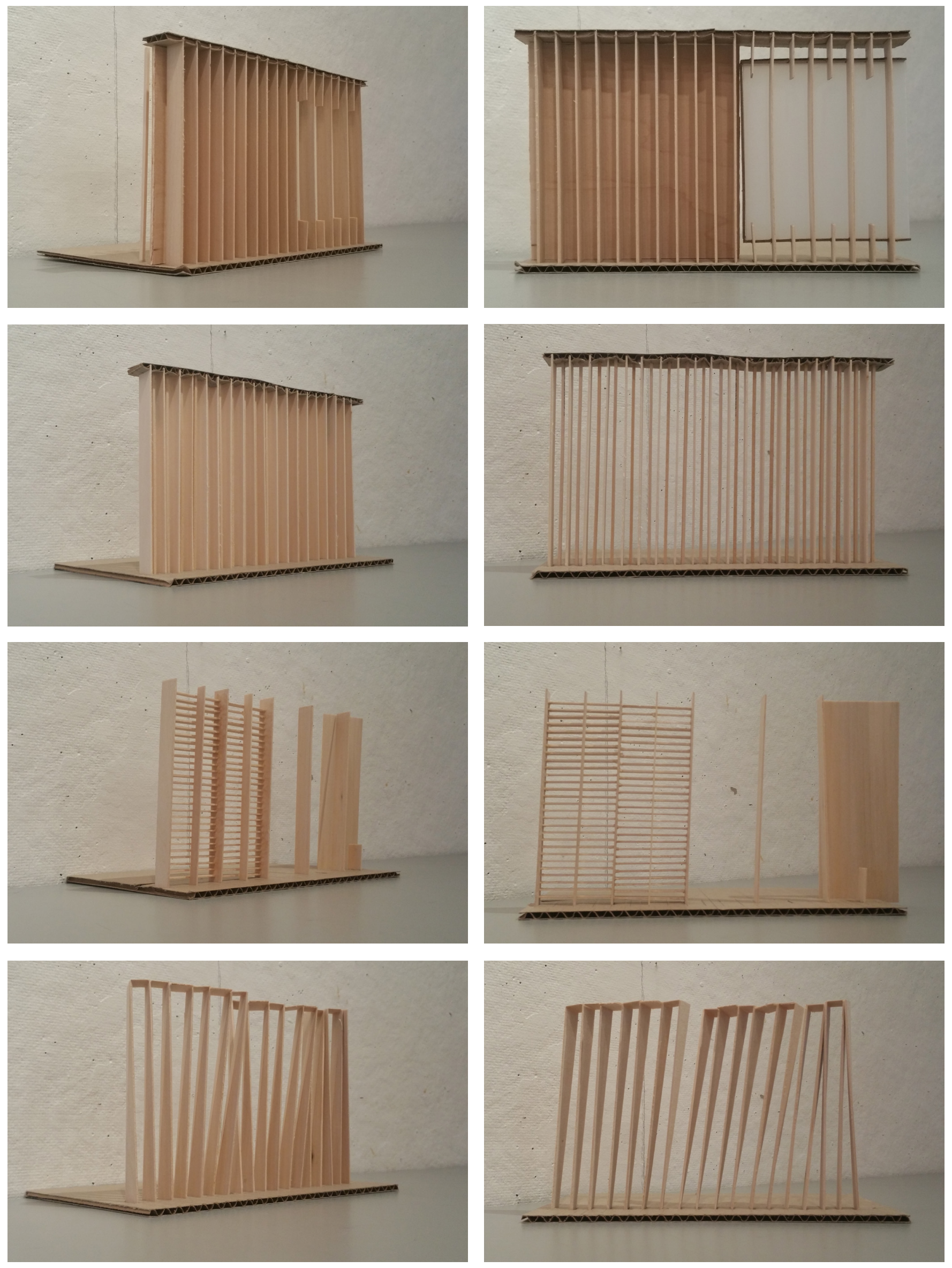


\section{Appendix F | Final Physical Model}
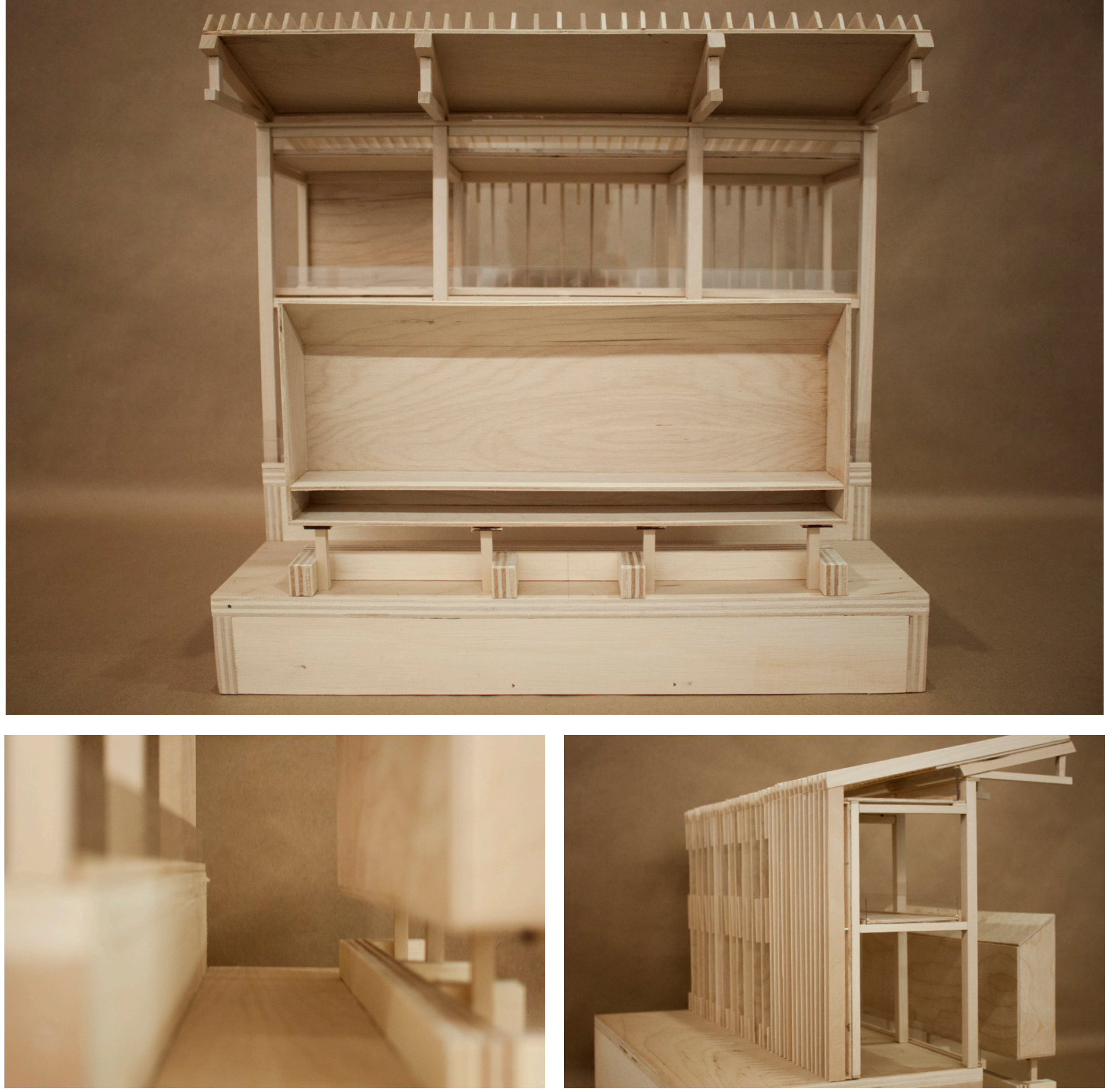


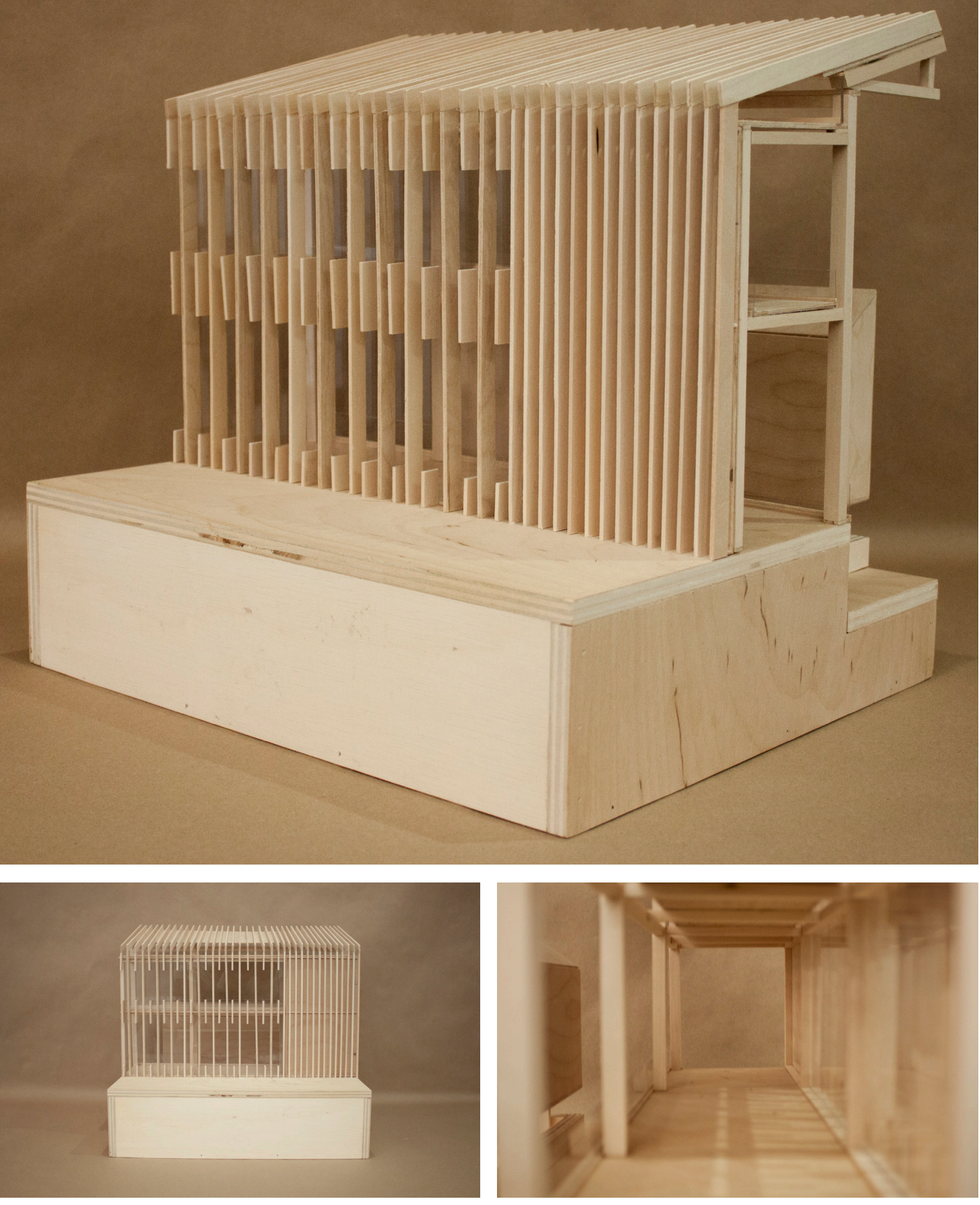




\section{Works Cited}

Archaeological Service Inc. (2004). Stage 1 Archeaological Assessment of the Proposed National Hotel, The New Fort Canadian National Exhbition Grounds City of Toronto.

Archaeological Service Inc. (2009). Stage 2 Archaeological Assessment of Proposed Hotel Development, the New fort Site (AjGu-32), Exhbition Place, City of Toronto, Ontario.

Archaeological Service Inc. (2014). Stage 4 Archaeological Excavation of Construction Impacts to the East Enlisted Men's Barracks, New Fort Site ( AjGu-32) Exbition Place, City of Toronto. E. MacDonald \& W. Oldham (Eds.). Toronto, ON: ASI.

Archaeological Service Inc. \& Historic Horizon Inc. ( 2005). Stage 2 Archaeological Assessment of Phase 1, Proposed National Hotel, The New Fort (AjGu-32), Exhbition Place, City of Toronto, Ontario.

Bailey, G., (2006). Time Perspectives, Palimpsests And The Archaeology Of Time. Journal of Anthropological Archaeology, 26(2007), 198-223.

Bartolini, N., (2014). Critical urban heritage: From palimpsest to brecciation. International Journal of Heritage Studies, 20(5), 519-533.

Bedard, J.F., (1994). Title In Cities of Artifical Excavation: the work of Peter Eisenman 1978-1988. Montreal, QC: Canadian Centre for Architecture

Bloszies, C., (2012). Old Building, new design: architectural transformations. New York, NY: Princeton Architectural Press.

Bollack, F.A., (2013). Old builds, new forms: New directions in architectural transformations. New York, NY: The Monacelli Press

Brooker, G. \& Stone, S., (2004). Rereadings: Interior architecture and the design principles of remodelling exisitng buildings. London, UK.: RIBA Enterprises. 
Busa, A., (2008). Palimpseststadt: The city of Layers. Memory Amnesia and Urbanism, MUDOT, 26-29. Retreived from http://www.monu.org/ mudot1/AB.pdf

Canada's Historic Places, (2010). Standards and Guidelines for the conservation of historic places in Canada (2nd ed.). Retieved from http:// www.historicplaces.ca/media/18072/81468-parks-s+g-eng-web2.pdf

City of Toronto, City Clerk's Office., (2014). 2 Strachan Avenue (Officers' Quarters, Stanly Barracks). Amendment of Desginating By-law Public Notice. Retrieved from https://www1.toronto.ca/wps/portal/contenton ly?vgnextoid=e9e3f4a0c8c46410VgnVCM10000071d60f89RCRD\&vgne xtchannel=f6a300ad867a0410VgnVCM10000071d60f89RCRD

City of Toronto, City Council Briefing., (2014). Exhibition Place Growth Strategies Launch of Privately Funded Convention Hotel in City Council Briefing Book 2014-2018. Retrieved from https://www1.toronto. ca/City\%200f\%20Toronto/City\%20Managers\%200ffice/Civic\%20 Engagement/2014\%20Council\%20Briefings/Files/CBB\%20Vol\%20 2/4.5\%20Exhibition\%20Place\%20-\%20Privately\%20Funded\%20 Convention\%20Hotel.pdf

Corboz, A., (1983). The Land as Palimpsest. Diogenes, 31(121), 12-34.

De Quincey, T. (1998). 'The palimpsest', in Thomas De Quincey: Confessions of an English Opium Easter and Other Writings . G. Lindop ed. Oxford, UK: Oxford University Press.

Dillon, S., (2005) Reinscribing De Quincey's palimpsest: The significance of the palimpsest in contemporary literary and cultural studies. Textual Practice, 19(3), 243-263.

Eisenman, P., (1994). Cities of artificial excavation: the work of Peter Eisenman 1978-1988. Montreal, QC: Canadian Centre for Architecture

Eisenman, P., (2004). Eisenman inside out: selected writing 1963-1988. New Haven, CT: Yale University Press.

Exhibition Place., (2011). Festival Plaza Site at Exhbition place Toronto Master Plan. Retrieved from http://www.explace.on.ca/database/rte/ files/Festival\%20Plaza\%20Master\%20Plan\%20\%231.pdf

Exhibition Place., (2014). Exhbition Place: Strategic Plan 2014-2016. Retrieved from http://www1.toronto.ca/City\%200f\%20Toronto/City\%20 Managers\%200ffice/Agencies\%20and\%20Corporations/Files/pdf/ Exhibition\%20Place\%20Strategic\%20Plan\%202014-2016.pdf

Fehn, S., (1992). The poetry of the Straight Line. Helsinki: Museum of Finnish Architecture, 17

Freud, S., (1961). Civilization and its discontents. New York, NY: Norton

Huyssen, A., (2003). Present Pasts: Urban palimpsests and the politics of memory. Stanford, Calif.: Stranford Univeristy Press. 
Jackson, J.B., (1994). A Sense of Place, a Sense of Time. New Haven, Conn.: Yale Yniversity Press.

Kjerrgren, L., (2011). Layers of land: the palimpsest concept in relation to landscape architecture. SLU Swedish University of Agricultural Sciences, 1-24. Retrieved from http://stud.epsilon.slu.se/3301/1/ kjerrgren_I_111004.pdf (EX0529)

Klanten, R., \& Feireiss, L. (Eds.)., (2009). Build-on: Converted architecture and transfromed buildings Berlin: Gestalten

Koolhaas, R., (2014, January 3). OMA now preoccupied with the countryside and preservation says Rem Koolhaas in Dezeen interview. Retrieved from https://www.youtube.com/watch?v=rGCsL4Ps24g

Koolhaas, R., (2014). Preservation is overtaking us. J. Carver (Ed). New York, NY: GSAPP Books

Koolhaas, R., \& Mau, B., (1998). The Generic City in S, M, L, XL: Office for Metropolitan Architecture. New York, NY: Monacelli Press, 1239 -1994

Lewington, J., (2009, Oct ober 07). Let's go to the Ex's boutique hotel. The Globe and Mail. Retrieved from http://www.theglobeandmail.com/ news/toronto/lets-go-to-the-exs-boutique-hotel/article4195952/

Lynch, K., (1972). What time is this place? Cambridge, Mass.: MIT Press.

Lyndon, D., (2009). The place of memory. In Spatial Recall, M. Treilb (Ed.). New York: NY: Routledge, 62-85.

Marot, S., (2010, December 6). Palimpsestous Ithaca: A relative manfiesto for sub-urbansim. Frederick Law Olmsted Lecture [Video]. Retrieved from https://www.youtube.com/watch?v=43WPtJOoSf4

Martin, P., (2013). Shelter for Roman Archaeological Site. Retrieived from http://www.arcspace.com/features/atelier-peter-zumthor/shelters-forroman-archaeological-site/

OMA, (2010). Venice Biennale 2010: Cronocaos. Retrieived from http:// oma.eu/projects/venice-biennale-2010-cronocaos

Ornelas, W., (1995). Typology and Rafael Moneo's Museum of Roman Art at Merida. 83rd ACSA Annual Meeting History, Theory, Criticim. 189. 194 Retrieved from http://apps.acsa-arch.org/resources/proceedings/ uploads/streamfile.aspx?path=ACSA.AM.83\&name=ACSA.AM.83.40.pdf

Otero-Pailos, J., (2014). Supplement to OMA's Preservation Manifesto in Preservation is overtaking us. J. Caver (Ed). New York, NY: GSAPP Books Oxford English Dictionary Online, (2015). "Palimpsest, n. and adj." Oxford Univeristy Press. Retreived from http://www.oed.com.ezproxy. lib.ryerson.ca/view/Entry/136319?rskey=1erWWo\&result $=1$

Popkin, N., (2012, October 30). Hidden City Philadelphia, In palimpsest, a way of thinking about preservation. Retrieved from http://hiddencityphila. 
org/2012/10/in-palimpsests-a-way-of-thinking-about-preservation/ Raskin, L., (2011). Jorge Otero-Paolos and the Ethics of Preservation. Retrieved from https://placesjournal.org/article/jorge-otero-pailos-andthe-ethics-of-preservation/

Renders, A., (2012). Recapping the Julian Smith Event. Retrieved from http://cityecology.net/2012/11/28/recapping-the-julian-smith-event/

Ring, P., (2008). Re Use: Archaeology and Storytelling. Interdisciplinary Studies in the Built and Virtual Environment, 1(2), 1-9.

Rossi, A., (1982). The architecture of the city. Cambridge, Mass.: MIT Press.

Ruskin, J., (1849). Seven lamps of architecture. New York, NY: John Wiley \& Sons.

Semes, S.W., (2009). The future of the past: a conservation ethic for architecture, urbanism, and historic preservation. New York, NY: W.W. Norton and Co.

Sendzikas, A., (2011). Stanley Barracks: Toronto's military legacy. Toronto, ON: Natural Heritage Books

Shields, J.A.E., (2014). Sverre Fehn's Hamar Bispegaard Museum in Collage and Architecture. Florence, KY: Rouledge, 237-246

Smith, J., (2012, November 14). Julian Smith: Exploring Cultral Landscape. Retrieved from https://www.youtube.com/watch?v=qHCeek9q7LA

Treib, M. (Ed.). (2009). Spatial recall: memory in architecture and landscape. New York: Routledge.

Tschumi, B., (1996). Architecture and disjunction. Cambridge, Mass.: MIT Press.

Verheij, R., (2015). Palimpsest in Architecture: six personal obersvations. Delft Univeristy of Technology, Faculty of Architecture, 1-176. Retrieved from repository.tudelft.nl/assets/.../1_thesis_robbert_verheij_1511734.pdf

Viollet-le-Duc, E.E. (1990). The Foundations of Architecture: Selections from the Dictionnaire Raisonne. (K.D. Whitehead, Trans.). New York, NY: George Braziller. (Original work published 1866)

Yates, F., (1966). The art of memory. Chicago, IL: University of Chicago Press. 


\section{Works Considered}

Abramson, D. (Fall 2001). Make history, not memory. Harvard Design Magazine No.9 P 78.84

Allen, S., (2006). Trace elements. In Davidson, Cynthia(red.) Tracing Eisenman: Peter Eisenman Complete works. London: Thames and Hudson.

Ames, D. L., \& Wagner, R. D. (2009). Design \& historic preservation: the challenge of compatibility : held at Goucher College, Baltimore, Maryland, March 14-16, 2002. Newark: University of Delaware Press.

Ardakani, M. K., \& Oloonabadi, S. S. (2011). Collective memory as an efficient agent in sustainable urban conservation. Procedia Engineering, 21, 985-988.

Arthur, E. R., \& Otto, S. A. (1986). Toronto: no mean city (3rd ed.). Toronto: Buffalo :.

Ashton, K. (2007, June 2). Palimpsest as a Layered Progression of Change Through Use. Synaptic Flux. Retrieved October 7, 2014, from http:// www.synapticflux.com/portfolio/palimpsest-as-a-layered-progressionof-change-through-use

Avermaete, T., Havik, K., \& Teerds, H. (2009). Architectural positions: architecture, modernity, and the public sphere. Amsterdam: SUN Publishers.

Azimzadeh, M., \& Bjur, H. (2007). The urban palimpsest: the interplay between the historically generated layers in urban spatial system and urban life. 6th International Space Syntax Symposium, 6(12), 1-14. Blackett, M., (2010). Building on History. Spacing Magazine, 11. Retrieved from http://spacing.ca/magazine/issue/issue11/building-on-history/

Bloomer, K. C. (1987). Memory and the poetics of architectural time. Crit, (18), 23-30. Retrieved from http://ezproxy.lib.ryerson.ca/ 
login?url=http://search. proquest.com/docview/55163866?account id $=13631$

Borden, I. (2001). The unknown city: contesting architecture and social space : a Strangely Familiar project. Cambridge, Mass.: MIT Press.

Boyer, M. C. (1994). The city of collective memory: its historical imagery and architectural entertainments. Cambridge, Mass.: MIT Press.

Cohen, N. (2001). Urban planning conservation and preservation. New York: McGraw-Hill.

Coombs, Tamara. (1992). Scarpa's Castelvecchio: A Critical Rehabilitation [Speaking of Places]. Places, 8(1), 4. Retrieved from: http://www. escholarship.org/uc/item/6ws3f5zn

Crinson, M. (2005). Urban memory: history and amnesia in the modern city. London: Routledge.

Davidson, C. C. (1999). Anytime. Cambridge, Mass.: MIT Press.

Dovey, K. (2010). Becoming places: urbanism/architecture/identity/ power. London: Routledge.

Fram, M. (2003). Well-preserved: the Ontario Heritage Foundation's manual of principles and practice for architectural conservation (3rd rev. ed.). Erin, Ont. Canada: Boston Mills Press.

Groote, B. (2014). The Palimpsest as a Double Structure of Memory. Orbis Litterarum Orbis Litter, 108-133.

Grundhauser, E. (2010). San Cataldo Cemetery. Atlas Obscura. Accessed 08 Oct 2014

Hatfield, E., (2012). Archaeologists unearth Toronto history at Stanley Barracks. Inside Toronto. Retrieved from http://www.insidetoronto.com/ news-story/78579-archaeologists-unearth-toronto-history-at-stanleybarracks/

Jung, C. G., \& Hull, R. F. (1980). The archetypes and the collective unconscious (2nd ed.). Princeton, N.J.: Princeton University Press.

Khirfan, L. (2010). Traces on the palimpsest: Heritage and the urban forms of Athens and Alexandria.Cities, 27(5), 315-325.

Krababa, A. (2012). An urban reading in-between past and future: Palimpsest identity. Istanbul Technical University,10(1), 50-62.

Krinke, R., (2001) Overview: design practice and manufactured sites. In Kirkwood, Niall (red.) Manufactured sites. London:Spoon Press.

Libeskind, D. (Speaker) (2001, April 3). Architecture: The Future of Memory. Slought. Lecture conducted from Slought and Kelly Writers House, Philadelphia. 
MacDonald, M., Macdonald, R., Miklavcic, I., Robertson, D. and Williamson, R. (2003). The Archaeological Master Plan of the Central Waterfront City of Toronto, Ontario. Archeological Services Inc. Toronto

Marot, S. (2003). Sub-urbanism and the art of memory. London: Architectural Association.

McBride, J., \& Wilcox, A. (2005). UTOpia: towards a new Toronto. Toronto: Coach House Books.

Orbasli, A. (2008). Architectural conservation: principles and practice. Malden, MA: Blackwell Science.

Ormrod, D. (1993). Conference: reflecting cities collective memory, multiculturalism and urban muselology.London Journal, 18(2), 171-174.

Otero-Pailos, J. (2006). Creative Agents. In J. Otero-Pailos, Future Anterior 3.1 (pp. i-vii).

Otero-Pailos, J. (2009) Mnemonic Value and Historic Preservation. In M. Treilb (Ed.), Spatial Recall (pp. 240-259). New York: NY, Routledge

Otero-Pailos, J. (2012). Restoration Redux. Architectural Record, 42-43.

Pallasmaa, J., (2009). Space, Place, Memory and Imagination: the temporal dimension of existential space. In M. Treib (Ed.), Spatial Recall (pp 16-41). New York,NY: Routledge.

Poon, J. C. N. (2008). Palimpsest: The Future of the Past. Visible Language, 42(3), 237-263. Retrieved from http://ezproxy.lib.ryerson. ca/login?url=http://search. proquest.com/ docview/232919436?acco untid $=13631$

Said, E.W. (2000). Invention, memory and place. Critical inquiry, 26, 175-192.

Schulz, C. (1971). Existence, space \& architecture. New York: Praeger.

Schulz, C. (1980). Genius loci: towards a phenomenology of architecture. New York: Rizzoli.

Tung, A. M. (2001). Preserving the world's great cities: the destruction and renewal of the historic metropolis. New York: Clarkson Potter.

Tzortzi, K. (2004). Building and exhibition layout: Sainsbury Wing compared with Castelvecchio. Architectural Research Quarterly, 18(2), 128-140.

Waldheim, C. (2006). The landscape urbanism reader. New York: Princeton Architectural Press.

Walkowitz, D. J., \& Knauer, L. M. (2004). Memory and the impact of political transformation in public space. Durham, N.C.: Duke University Press. 
Wertsch, J. V. (2002). Voices of collective remembering. New York: Cambridge Univ Press.

Williamson, K. (2010). Development and design of heritage sensitive sites: strategies for listed buildings and conservation areas. London: Routledge. 